INSTITUTO DE PESQUISAS ENERGÉTICAS E NUCLEARES

Autarquia associada à Universidade de São Paulo

\title{
INFLUÊNCIA DE AGENTES CONTROLADORES DE PROCESSO NA SÍNTESE POR COMBUSTÃO MECANICAMENTE ATIVADA DO NbAl ${ }_{3}$
}

VALERIA DE SÁ GONÇALVES

Tese apresentada como parte dos requisitos para obtenção do Grau de Doutor em Ciências na Área de Tecnologia Nuclear - Materiais.

Orientador:

Dr. Ricardo Mendes Leal Neto

SÃO PAULO 
Dedico este trabalho à minha querida mamãe, "Haja o que houver, eu estarei sempre com você." Meu profundo amor e eterna gratidão. Obrigada mamãe. 


\section{AGRADECIMENTOS}

Em especial, ao meu orientador Dr. Ricardo Mendes Leal Neto, pela confiança depositada em mim e, sobretudo, pela imensa compreensão, incentivo e participação preciosa e paciente em todas as etapas deste trabalho.

Ao meu colega de pesquisa e querido amigo Dr. Cláudio José da Rocha, pela incomensurável ajuda e apoio em vários momentos deste trabalho.

Ao Dr. Mauro César Terence pela atenção e presteza na realização das análises por espectroscopia no infravermelho, e pela sempre disposição em discutir os resultados pertinentes a este trabalho.

Ao Dr. Roy Edward Bruns que, com sua larga experiência nas metodologias de planejamentos de experimentos, contribuiu de forma valiosa nas discussões e análise dos resultados parciais deste trabalho, e por ter aceitado participar prontamente da banca examinadora.

Ao Dr. Sérgio Luis de Jesus, integrante do Núcleo de Pesquisas Geológicas da Escola Superior de Agronomia e Agricultura Luiz de Queiroz (ESALQ), por ter disponibilizado preciosa parte de seu tempo para realizar as sempre urgentes análises por microscopia eletrônica de varredura.

À empresa Cennabras Indústria e Comércio Ltda., em especial ao Eng. Aurelindo Leme Silva, pela compreensão e apoio em todos os momentos que precisei me ausentar para me dedicar exclusivamente a esta tese.

Ao meu querido Edson Souza de Jesus Filho, pela inigualável compreensão e apoio nos momentos mais difíceis deste trabalho, e pela presença, incentivo e ajuda constante.

Ao meu pai de coração, Sebastião Noronha, por me proporcionar a felicidade de fazer parte de sua vida.

A todos os meus queridos amigos, com os quais posso contar sempre em todos os momentos. 
"Existem dois mundos: o mundo que podemos medir com régua e compasso e o que sentimos com nosso coração e imaginação."

Leigh (games Henry) Hunt (1784-1859)

Ensaísta inglês

"O resultado de qualquer pesquisa científica séria só pode ser o surgimento de duas novas questões, onde antes só havia uma."

Thornste in Veblen (1857-1929)

Sociólogo ame ric ano

"O corpo humano é a carruagem; eu, o homem que a conduz;o pensamento são as rédeas; os sentimentos, os cavalos."

Platão (428-348 a.C.)

Filós ofo grego 


\title{
INFLUÊNCIA DE AGENTES CONTROLADORES DE PROCESSO NA SÍNTESE POR COMBUSTÃO MECANICAMENTE ATIVADA DO NbAl ${ }_{3}$
}

\author{
Valeria de Sá Gonçalves
}

\section{RESUMO}

Neste trabalho, foi investigada a influência de alguns agentes controladores de processo (ACP), a saber: ácido esteárico, etanol, metanol e ciclohexano, na ativação mecânica de misturas de pós de $25 \%$ at. de nióbio e $75 \%$ at. de alumínio (correspondente à estequiometria do composto intermetálico $\mathrm{NbAl}_{3}$ ), com posterior reação de combustão. Os agentes foram adicionados à mistura em questão com o intuito de estabelecer um equilíbrio entre os eventos de soldagem e fratura durante o processamento em moinho de alta energia SPEX ${ }^{\circledR}$ 8000. A influência das variáveis (tipo e quantidade) relativas aos ACPs na densidade relativa das pastilhas reagidas de $\mathrm{NbAl}_{3}$ foram avaliadas mediante a elaboração de planejamentos de experimentos, do tipo composto central para dois fatores, para cada agente. Foi possível construir modelos empíricos para os ACPs ácido esteárico, metanol e ciclohexano, capazes de relacionar numericamente as variáveis (tempo de moagem e quantidade de ACP) investigadas em cada planejamento e indicar a melhor condição para se obter a otimização da resposta avaliada. Os resultados das análises de distribuição granulométrica e a caracterização microestrutural por microscopia eletrônica de varredura permitiram avaliar os efeitos dos agentes na distribuição do tamanho de partículas e na formação dos agregados de Nb/Al. A influência dos ACPs na evolução da reação de combustão foi avaliada mediante a análise das temperaturas de ignição registradas durante o processo. A espectroscopia no infravermelho possibilitou sugerir um mecanismo para a atuação do ácido esteárico e dos álcoois (etanol e metanol) com os pós metálicos durante a moagem. Constatou-se que os agentes afetam de forma significativa o processo de ativação mecânica, resultando em diferentes resultados de densidade relativa. Essa influência depende do tempo de moagem adotado. Os efeitos mais pronunciados na cinética de moagem e as maiores densidades relativas para o $\mathrm{NbAl}_{3}$ foram obtidos com o uso dos agentes ácido esteárico e etanol. 


\title{
INFLUENCE OF PROCESS CONTROL AGENTS ON THE MECHANICALLY ACTIVATED COMBUSTION SYNTHESIS OF NbAI ${ }_{3}$
}

\author{
Valeria de Sá Gonçalves
}

\begin{abstract}
In this work, the influence of some process control agents (stearic acid, ethanol, methanol and cyclohexane) in the mechanical activation of powder mixtures of $25 \%$ at. niobium and $75 \%$ at. aluminum (stoichiometry of the intermetallic compound $\mathrm{NbAl}_{3}$ ) followed by combustion synthesis reaction, was investigated. The process control agents (PCA) were added to the mixtures to establish a balance between welding and fracture of powder particles during high energy ball milling in SPEX ${ }^{\circledR} 8000$. The influence of PCAs' variables (type and quantity) in $\mathrm{NbAl}_{3}$ bulk densities was evaluated by central composites experimental designs elaborated for each PCA. It was possible to construct empirical models for stearic acid, methanol and cyclohexane. These models were able to establish the relationship between the investigated variables (milling time and quantity of PCA) and to indicate the better conditions to optimize the response. Particle size and SEM microstructural analysis allowed evaluating the effects of PCAs on size distribution and formation of $\mathrm{Nb} / \mathrm{Al}$ aggregates. The influence of PCAs on the combustion reaction was evaluated by recording the thermal profiles of the pellets during the process. From the results of the infrared spectroscopy analysis it was possible to suggest a mechanism for the behavior of stearic acid and alcohols (ethanol and methanol) with metallic powders during milling. It was verified that PCAs affect significantly the mechanical activation process, resulting in $\mathrm{NbAl}_{3}$ pellets with different bulk densities. This influence depends on the milling time utilized. The more pronounced effects in the milling kinetic and major densities were produced with stearic acid and ethanol agents.
\end{abstract}




\section{SUMÁRIO}

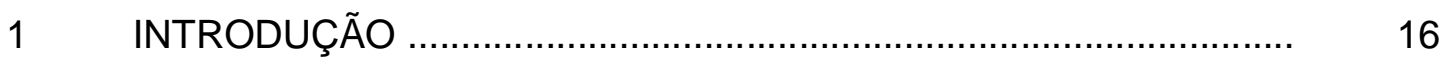

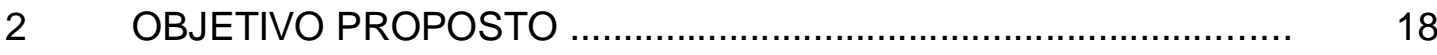

3 REVISÃO DA LITERATURA …….................................................... 18

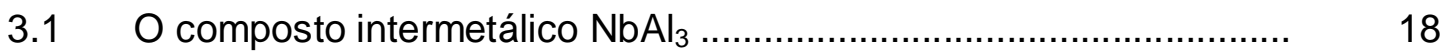

3.2 As reações de combustão ............................................................... 20

3.3 A moagem com alta energia ………………………………....... 21

3.4 O processo de síntese por combustão mecanicamente ativada ....... 23

3.5 Os agentes controladores de processo (ACPs) ............................... 24

3.5.1 Mecanismo proposto para a atuação dos ACPs durante a moagem 24

3.5.2 Influência dos ACPs na moagem de materiais dúcteis ..................... 25

3.5.3 Decomposição dos ACPs durante a moagem ................................ 26

3.5.4 Reatividade de compostos orgânicos com materiais metálicos e cerâmicos .......................................................................... 28

3.5.5 Influência dos compostos orgânicos na reação de combustão ......... 28

$4 \quad$ MATERIAIS E MÉTODOS ….......................................................... 30

4.1 Planejamento de experimentos ...................................................... 30

4.2 Preparação das misturas mecanicamente ativadas ......................... 34

4.2.1 Caracterização das misturas após moagem com alta energia ......... 37

4.3 Compactação das misturas moídas ................................................... 39

4.4 Reações de combustão ………………………………………...... 40

4.4.1 Caracterização das pastilhas reagidas ............................................. 41

5 RESULTADOS E DISCUSSÃO .......................................................

$5.1 \quad$ Planejamento de experimentos ................................................... 44

5.1.1 Planejamento composto central para o ácido esteárico .................... 44

5.1.2 Planejamento composto central para o etanol .................................. 52 
5.1.3 Planejamento composto central para o metanol ............................. 56

5.1.4 Planejamento composto central para o ciclohexano ........................ 62

5.1.5 Correlação entre os ACPs ................................................................ 68

5.1.6 Síntese dos principais resultados obtidos nos planejamentos ......... 70

5.2 Caracterização das misturas mecanicamente ativadas ..................... 73

5.2.1 Forma e distribuição do tamanho de partículas ...............................

5.2.2 Microestrutura das misturas mecanicamente ativadas .................... 83

5.2.3 Difração de raios $X$ das misturas mecanicamente ativadas ............. 96

5.2.4 Espectroscopia no infravermelho das misturas moídas ................... 100

5.3 Perfis de temperatura das pastilhas reagidas .................................. 105

5.4 Caracterização das pastilhas reagidas ........................................... 113

5.4.1 Microestrutura das pastilhas reagidas ………................................. 113

5.4.2 Difração de raios $X$ das pastilhas reagidas …………………......... 117

5.5 Síntese dos principais resultados obtidos na caracterização dos pós moídos e das pastilhas reagidas .......................................... 119

$6 \quad$ CONCLUSÕES ..................................................................... 123

7 SUGESTÕES PARA TRABALHOS FUTUROS .............................. 125

ANEXO - Conceitos principais para a interpretação dos resultados obtidos nos planejamentos de experimentos ......................... 126

REFERÊNCIAS BIBLIOGRÁFICAS ................................................... 130 


\section{LISTA DE TABELAS}

TABELA 1 - Níveis das variáveis investigadas para cada ACP.

TABELA 2 - Matriz de planejamento com os níveis das variáveis (tempo de moagem e quantidade de ACP: $x_{1}$ e $x_{2}$, respectivamente) codificados.

TABELA 3 - Propriedades físicas dos ACPs utilizados neste estudo (Merck Index, 1983).

TABELA 4 - Parâmetros de moagem empregados no processo.

TABELA 5 - Resultados do planejamento composto central para o ácido esteárico. Os níveis das variáveis estão codificados.

TABELA 6 - Análise de variância (ANOVA) para o ácido esteárico. ........

TABELA 7 - Análise de variância (ANOVA) para o ácido esteárico $(\mathrm{I} . \mathrm{C}=99 \%)$.

TABELA 8 - Estimativa do grau de significância das variáveis para o ácido esteárico.

TABELA 9 - Resultados do planejamento composto central para o etanol. Os níveis das variáveis estão codificados.

TABELA 10 - Análise de variância (ANOVA) para o etanol.

TABELA 11 - Resultados do planejamento composto central para o metanol. Os níveis das variáveis estão codificados.

TABELA 12 - Análise de variância (ANOVA) para o metanol.

TABELA 13 - Estimativa do grau de significância das variáveis para o metanol.

TABELA 14 - Resultados do planejamento composto central para o ciclohexano. Os níveis das variáveis estão codificados. 
TABELA 15 - Análise de variância (ANOVA) para o ciclohexano.

TABELA 16 - Estimativa do grau de significância das variáveis para o ciclohexano.

TABELA 17 - Correlação entre os ACPs.

TABELA 18 - Densidades obtidas nas condições de maior densidade e padrão (indicadas entre parênteses).

TABELA 19 - Modelo adotado no planejamento de cada ACP

TABELA 20 - Distribuição granulométrica dos pós moídos na condição padrão.

TABELA 21 - Distribuição granulométrica dos pós moídos por 30 minutos com $1,5 \%$ de cada ACP.

TABELA 22 - Distribuição granulométrica dos pós moídos por 60 minutos com $1,7 \%$ de cada ACP.

TABELA 23 - Distribuição granulométrica dos pós moídos por 90 minutos com $1,5 \%$ de cada ACP.

TABELA 24 - Análises de imagens das misturas moídas por 30 e 60 minutos.

TABELA 25 - Fração volumétrica do constituinte eutético das pastilhas reagidas a partir das misturas moídas por 30 minutos.

TABELA 26 - Temperaturas de ignição $\left(T_{i g}\right)$ e densidades relativas das pastilhas de $\mathrm{NbAl}_{3}$. 


\section{LISTA DE FIGURAS}

FIGURA 1 - Diagrama de fases do sistema Nb-Al (Kattner, 1996). ........

FIGURA 2 - Esquema dos principais estágios envolvidos no processo de moagem com alta energia de materiais dúcteis (Benjamin e Volin, 1974).

FIGURA 3 - Representação geométrica de um planejamento composto central para dois fatores (Barros Neto et al., 2002).

FIGURA 4 - Ilustrações do moinho agitador e do recipiente utilizados nas moagens com alta energia.

FIGURA 5 - $\quad$ llustrações dos componentes que são inseridos no interior do forno. (a) Tubo de quartzo, termopar recoberto com lama de alumina e pastilha compactada. (b) Posicionamento do termopar na superfície da pastilha. .....

FIGURA 6 - Metodologia empregada para a estimativa da temperatura de ignição. (a) Exemplo de perfil de temperatura registrado pelo sistema de aquisição. (b) Detalhe da região indicada em (a).

FIGURA 7 - Representação geométrica dos resultados obtidos no planejamento composto central para o ácido esteárico. A seta vermelha indica a direção para a otimização da resposta.

FIGURA 8 - Resíduos relativos ao modelo adotado para o ácido esteárico. A disposição dos pontos não possui uma aparência muito aleatória.

FIGURA 9 - $\quad$ Superfície de resposta descrita pela equação 5.2. ............. 51

FIGURA 10 - Curvas de nível para a equação 5.2. ................................... 51

FIGURA 11 - Representação geométrica dos resultados obtidos no planejamento composto central para o etanol. A seta vermelha indica a direção para a otimização da resposta..

FIGURA 12 - Resíduos relativos ao modelo adotado para o etanol. É possível observar certo padrão na distribuição dos resíduos. 
FIGURA 13 - Representação geométrica dos resultados obtidos no planejamento composto central para o metanol. A seta vermelha indica a direção para a otimização da resposta..

FIGURA 14 - Resíduos relativos ao modelo adotado para o metanol. ....

FIGURA 15 - Superfície de resposta descrita pela equação 5.4 ............. 61

FIGURA 16 - Curvas de nível para a equação 5.4 .................................. 62

FIGURA 17 - Representação geométrica dos resultados obtidos no planejamento composto central para o ciclohexano. A seta vermelha indica a direção para a otimização da resposta.

FIGURA 18 - Resíduos relativos ao modelo adotado para o ciclohexano.

FIGURA 19 - Superfície de resposta descrita pela equação 5.5. ............ 67

FIGURA 20 - Curvas de nível para a equação 5.5. ................................. 68

FIGURA 21 - Representação gráfica da correlação entre as densidades relativas obtidas para os agentes ácido esteárico e etanol.

FIGURA 22 - Representação gráfica da correlação entre as densidades relativas obtidas para os agentes metanol e ciclohexano. .

FIGURA 23 - Micrografias eletrônicas de varredura (elétrons secundários) dos pós moídos na condição padrão. $\mathrm{O}$ ACP, juntamente com a densidade obtida, está indicado em cada caso.

FIGURA 24 - Micrografias eletrônicas de varredura (elétrons secundários) dos pós moídos por 30 minutos com 0,5 e $1,5 \%$ de cada ACP.

FIGURA 25 - Micrografias eletrônicas de varredura (elétrons secundários) dos pós moídos por 60 minutos com 1,0 e $1,7 \%$ de cada ACP.

FIGURA 26 - Micrografias eletrônicas de varredura (elétrons secundários) dos pós moídos por 90 minutos com 0,5 e $1,5 \%$ de cada ACP. 
FIGURA 27 - Micrografias eletrônicas de varredura (elétrons retroespalhados) dos pós moídos na condição padrão. $O$ $\mathrm{ACP}$, juntamente com a densidade obtida, está indicado em cada caso.

FIGURA 28 - Micrografias eletrônicas de varredura (elétrons retroespalhados) dos pós moídos por 30 e 90 minutos. A quantidade de ACP utilizada está indicada em cada caso.

FIGURA 29 - Micrografias eletrônicas de varredura (elétrons retroespalhados) dos pós moídos com ácido esteárico por 30 e 60 minutos. As quantidades estão indicadas em cada caso.

FIGURA 30 - Micrografias eletrônicas de varredura (elétrons retroespalhados) dos pós moídos com etanol por 30 e 60 minutos. As quantidades estão indicadas em cada caso. ..

FIGURA 31 - Micrografias eletrônicas de varredura (elétrons retroespalhados) dos pós moídos com metanol por 30 e 60 minutos. As quantidades estão indicadas em cada caso.

FIGURA 32 - Micrografias eletrônicas de varredura (elétrons retroespalhados) dos pós moídos com ciclohexano por 30 e 60 minutos. As quantidades estão indicadas em cada caso.

FIGURA 33 - Micrografias eletrônicas de varredura (elétrons retroespalhados) dos pós moídos por 18 minutos com $1,0 \%$ de cada ACP.

FIGURA 34 - Seqüência do procedimento adotado nas análises de imagens.

FIGURA 35 - Difratogramas de raios X das misturas moídas por 30 minutos com os diferentes ACPs. Ácido esteárico e etanol $(0,5 \%)$; metanol e ciclohexano $(1,5 \%)$

FIGURA 36 - Difratogramas de raios X das misturas moídas por 60 minutos com $1,0 \%$ dos diferentes ACPs.

FIGURA 37- Difratogramas de raios $X$ das misturas moídas por 90 minutos com $0,5 \%$ dos diferentes ACPs.

FIGURA 38 - Difratograma de raios X do pó de nióbio. 
FIGURA 39 - Difratogramas de raios $X$ das misturas moídas por 18,60 e 102 minutos com 1,0\% de ácido esteárico.

FIGURA 40 - Espectros no infravermelho médio. (a) ácido esteárico; (b) pós moídos por 30 minutos com $1,5 \%$ de ácido esteárico.

FIGURA 41 - Espectros no infravermelho médio. (a) etanol; (b) pós moídos por 18 minutos com 1,0\% de etanol.

FIGURA 42 - Espectros no infravermelho médio. (a) metanol; (b) pós moídos por 18 minutos com $1,0 \%$ de metanol.

FIGURA 43 - Perfis de temperatura de pastilhas aquecidas a $30^{\circ} \mathrm{C} / \mathrm{min}$ a partir das misturas moídas na condição padrão com os diferentes ACPs.

FIGURA 44 - Perfis de temperatura de pastilhas aquecidas a $30^{\circ} \mathrm{C} / \mathrm{min}$ a partir das misturas moídas por 30 minutos. Ácido esteárico e etanol $(0,5 \%)$; metanol e ciclohexano $(1,5 \%)$.

FIGURA 45 - Perfis de temperatura de pastilhas aquecidas a $30^{\circ} \mathrm{C} / \mathrm{min}$ a partir das misturas moídas por 90 minutos com $0,5 \%$ de cada ACP.

FIGURA 46 - Perfis de temperatura de pastilhas aquecidas a $30^{\circ} \mathrm{C} / \mathrm{min}$ a partir das misturas moídas por 30 minutos com $0,5 \mathrm{e}$ $1,5 \%$ de cada ACP.

FIGURA 47 - Perfis de temperatura de pastilhas aquecidas a $30^{\circ} \mathrm{C} / \mathrm{min}$ a partir das misturas moídas por 60 minutos com 1,0 e $1,7 \%$ de cada ACP.

FIGURA 48 - Perfis de temperatura de pastilhas aquecidas a $30^{\circ} \mathrm{C} / \mathrm{min}$ a partir das misturas moídas por 90 minutos com $0,5 \mathrm{e}$ $1,5 \%$ de cada ACP.

FIGURA 49 - Micrografias eletrônicas de varredura (elétrons retroespalhados) das pastilhas reagidas e processadas na condição padrão.

FIGURA 50 - Micrografias eletrônicas de varredura (elétrons retroespalhados) das pastilhas reagidas e processadas a partir das misturas moídas por 30 e 90 minutos com os diferentes ACPs. 
FIGURA 51 - Micrografias eletrônicas de varredura (elétrons retroespalhados: a e b; e secundários: $c$ e d) das pastilhas reagidas a partir das misturas moídas por 30 minutos. (a) e (b): detalhe do constituinte eutético $\mathrm{Nb}_{2} \mathrm{Al}-$ $\mathrm{NbAl}_{3}$; (c) e (d): detalhe das partículas com alto teor de alumínio e oxigênio (tonalidade cinza escura) e partículas com alto teor de nióbio e carbono (tonalidade clara).

FIGURA 52 - Difratogramas de raios $X$ das pastilhas reagidas a partir das misturas processadas por 30 minutos. Ácido esteárico e etanol $(0,5 \%)$; metanol e ciclohexano (1,5\%).

FIGURA 53 - Difratogramas de raios $X$ das pastilhas reagidas a partir das misturas processadas por 60 minutos com 1,0\% de cada ACP.

FIGURA 54 - Difratogramas de raios $X$ das pastilhas reagidas a partir das misturas processadas por 90 minutos com $0,5 \%$ de cada ACP. 


\section{INTRODUÇÃO}

A concepção deste trabalho nasceu a partir das atividades ligadas ao projeto de auxílio individual à pesquisa "Síntese por Combustão Mecanicamente Ativada do Trialumineto de Nióbio, $\mathrm{NbAl}_{3}$ " (processo FAPESP n² 2001/03961-4), realizado no Laboratório de Síntese por Combustão de Intermetálicos do Centro de Ciência e Tecnologia de Materiais (CCTM) .

As investigações do grupo de pesquisa estão centradas, sobretudo, no estudo dos mecanismos relacionados ao processo de ativação mecânica (em moinhos de alta energia) de misturas de Nb75Al (correspondente, em proporção atômica, à estequiometria do composto intermetálico $\mathrm{NbAl}_{3}$ ), e sua influência em posterior reação de combustão simultânea. Dentre as inúmeras variáveis envolvidas no processo de moagem seguido de síntese por combustão, a utilização dos chamados agentes controladores de processo (comumente compostos orgânicos necessários para estabelecer um equilíbrio entre os eventos de soldagem e fratura durante a moagem de materiais dúcteis) na etapa de mistura dos pós elementares, revelou-se de extrema importância e apresentou indubitáveis efeitos na distribuição do tamanho de partícula e nas características microestruturais dos agregados de nióbio e alumínio formados durante a moagem, bem como na posterior densidade e homogeneidade do produto final.

Inicialmente os estudos foram realizados com o composto orgânico ácido esteárico (Rocha et al., 2003), que é o agente mais amplamente difundido na literatura, o qual apresentou uma influência significativa na formação e tamanho dos agregados, e nas características da reação (avaliadas, essencialmente, por meio da temperatura de ignição). A literatura sobre o assunto é voltada, sobretudo, aos efeitos de tais agentes no tamanho de partícula e rendimento de moagem.

Nesse contexto, cresceu a necessidade de realizar um estudo mais consistente no que tange à influência desses agentes na síntese por combustão mecanicamente ativada do $\mathrm{NbAl}_{3}$. Os efeitos dos agentes controladores de processo no que concerne à interação destes com as misturas moídas e seus efeitos na evolução da reação de síntese, bem como nas densidades obtidas no produto final, carece de uma investigação mais profunda, constituindo um aspecto 
inédito neste trabalho. Com esse intuito, buscou-se também avaliar os efeitos de compostos orgânicos representantes de outros grupos funcionais (álcool e cicloalcano) e propor modelos empíricos capazes de relacionar, na região investigada, o tipo e a quantidade de agente com a densidade das pastilhas do composto intermetálico $\mathrm{NbAl}_{3}$. 


\section{OBJETIVO PROPOSTO}

O objetivo principal proposto para o presente trabalho é investigar a influência das variáveis (tipo e quantidade) relativas ao ACP na combustão simultânea de misturas mecanicamente ativadas, de composição $\mathrm{Nb75Al}$ (estequiometria do $\mathrm{NbAl}_{3}$ ) e compactadas na forma de pastilhas cilíndricas. Nesse contexto, procura-se adquirir uma melhor compreensão no que concerne ao mecanismo de interação dos ACPs com os pós de Nb75Al durante a moagem com alta energia, e seus efeitos na reação de síntese e na densidade relativa do produto final.

\section{REVISÃO DA LITERATURA}

\subsection{O composto intermetálico $\mathrm{NbAl}_{3}$}

Os compostos intermetálicos podem ser definidos, de forma sucinta, como materiais constituídos por dois ou mais elementos com fortes ligações químicas entre átomos distintos, cuja rede cristalina difere da dos elementos puros. Esses compostos constituem uma classe de materiais com excelentes propriedades físicas e mecânicas, como elevados ponto de fusão e módulo de elasticidade, alta tensão de escoamento, baixa mobilidade atômica, entre outras. Tais características são resultantes das fortes ligações químicas entre seus distintos átomos e da estrutura cristalina ordenada desses materiais, que acarreta em uma limitação na mobilidade de discordâncias. As aplicações dos intermetálicos remontam ao início da metalurgia. Suas primeiras utilizações advinham da elevada dureza e excelente estabilidade química desses compostos (Sauthoff, 1995). Atualmente, os aluminetos e silicetos estão entre os intermetálicos mais estudados. Um conjunto de propriedades como alta resistência mecânica e à oxidação em elevadas temperaturas, acrescido a densidades reduzidas, os tornam potencialmente atraentes para aplicações estruturais em altas temperaturas. No que concerne ao sistema binário $\mathrm{Nb}$-Al, três fases intermetálicas podem ser distinguidas: $\mathrm{Nb}_{3} \mathrm{Al}, \mathrm{Nb}_{2} \mathrm{Al}$ e $\mathrm{NbAl}_{3}$, conforme o diagrama de fases 
apresentado na FIG. 1. Entre estas, o composto intermetálico $\mathrm{NbAl}_{3}$ (Nb75Al em \% at.) é considerado um candidato promissor e potencial para aplicações aeroespaciais e estruturais em temperaturas elevadas, decorrente de suas atraentes propriedades, tais como: alto ponto de fusão $\left(1680{ }^{\circ} \mathrm{C}\right)$, densidade relativamente baixa $\left(4,54 \mathrm{~g} / \mathrm{cm}^{3}\right)$ e boa resistência mecânica e à oxidação em altas temperaturas (Barth et al., 1992; Kachelmyer et al., 1995). Entretanto, em razão da sua fragilidade intrínseca à temperatura ambiente aliada à significativa diferença nos pontos de fusão de seus elementos constituintes $\left(\mathrm{Nb}=2408{ }^{\circ} \mathrm{C}\right.$; $\left.\mathrm{Al}=660^{\circ} \mathrm{C}\right)$ (Shackelford e Alexander, 2001), os métodos convencionais de obtenção desse composto (fusão à arco ou indução, metalurgia do pó associada à fusão, entre outros) apresentam muitas dificuldades, demandando o uso de equipamentos caros e complexos, além de requerer longos tempos de processamento (Sauthoff, 1995; Williams, 1997). Nesse contexto, a obtenção do $\mathrm{NbAl}_{3}$ via síntese por reações químicas exotérmicas (conhecidas como reações de combustão), que dependem da entalpia de formação dos produtos, apresentase como um método alternativo de grande interesse por envolver equipamentos mais simples e baratos, menor tempo de processamento e economia de energia, possibilitando ainda uma maior flexibilidade no controle da composição e microestrutura dos materiais obtidos mediante a manipulação das variáveis pertinentes ao processo (Kachelmyer et al., 1995; Moore e Feng, 1995; Patil et al., 2002; Subrahmanyam e Vijayakumar, 1992).

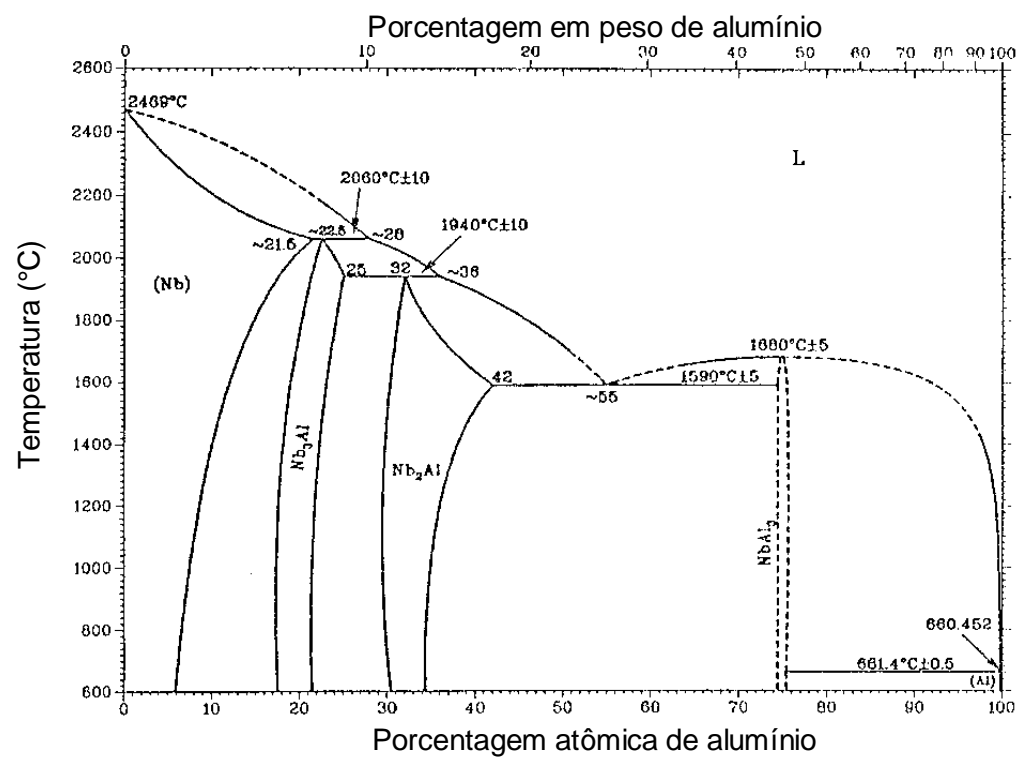

FIGURA 1 - Diagrama de fases do sistema Nb-Al (Kattner, 1996). 


\subsection{As reações de combustão}

A partir dos anos sessenta do século passado, as reações de combustão têm sido aplicadas com reconhecidas vantagens técnicas e econômicas na obtenção de uma grande variedade de materiais: carbetos, silicetos, boretos, nitretos e compostos intermetálicos. O processo caracteriza-se por envolver reações químicas altamente exotérmicas em uma mistura de reagentes, sob determinadas condições de temperatura e pressão. Esses reagentes são aquecidos até que seja atingida uma determinada temperatura (denominada de temperatura de ignição), na qual há uma quantidade de energia suficiente para iniciar e manter uma reação exotérmica auto-sustentável. Conforme as características das reações envolvidas (alta ou baixa exotermia do produto) e o modo de fornecimento de energia ao sistema (aquecimento local ou global da mistura), dois modos de combustão podem ser distinguidos, respectivamente: reação de combustão auto-sustentável (Self-Propagating High Temperature Synthesis), mais conhecida pela sigla SHS , e combustão simultânea ou explosão térmica. No primeiro, a reação é iniciada localmente, sendo capaz de autopropagar-se como uma "onda de combustão" pela mistura de reagentes, convertendo-os no composto desejado. No segundo, há um pré-aquecimento uniforme e controlado da mistura até a ignição, a partir da qual a reação ocorre espontaneamente por todo o volume da amostra. Este último geralmente é empregado na síntese de compostos com baixa exotermia, como é o caso do $\mathrm{NbAl}_{3}$ (Nb75Al), objeto deste estudo (Leal Neto et al., 2003; Varma e Mukasyan, 1998; Moore e Feng, 1995; Patil et al., 2002; Subrahmanyam e Vijayakumar, 1992).

A síntese por combustão, por envolver fenômenos complexos, requer um estudo e controle apurado de suas variáveis, que podem afetar significativamente a cinética da reação e as propriedades do produto final. Os efeitos de muitas dessas, como densidade a verde, tamanho e distribuição das partículas dos pós (no caso de reagentes sólidos), atmosfera e taxa de aquecimento, têm sido estudados e reportados na literatura (Munir e Anselmi Tamburini, 1989; Hibino et al., 2001; Kachelmyer et al., 1995; Moore e Feng, 1995; Subrahmanyam e Vijayakumar, 1992). Dentre as variáveis citadas, observou-se que o tamanho de partícula e o grau de dispersão dos reagentes para a obtenção de uma 
microestrutura altamente refinada e homogênea são de fundamental importância para o mecanismo da reação. Tal dispersão pode ser obtida por intermédio da moagem com alta energia, empregada na etapa de preparação da mistura dos pós dos elementos constituintes do composto (Benjamin, 1976; Suryanarayana, 2001).

\subsection{A moagem com alta energia}

Nos últimos anos, os efeitos da moagem com alta energia em misturas reagidas por combustão têm despertado grande interesse científico e sido objeto de estudo de alguns autores (Park e Shin, 2001; Liu e Guo, 1994; Gauthier et al., 1999; Takacs, 2002; Leal Neto e Rocha, 2001; Leal Neto et al., 2003; Rocha et al., 2003, 2006). Os moinhos de alta energia promovem altas velocidades e freqüências de impacto entre o meio de moagem e as partículas dos pós reagentes, produzindo misturas com um elevado grau de dispersão e defeitos cristalinos, além de promover um aumento na área de contato entre as partículas dos pós. Essa técnica foi desenvolvida e inicialmente utilizada por John $\mathrm{S}$. Benjamin em 1966, com o objetivo de produzir uma maior dispersão de fases cerâmicas em superligas (Benjamin, 1976). A moagem com alta energia é aplicada extensivamente em casos como: a elaboração mecânica de ligas (mechanical alloying), a moagem reativa (reactive milling), na obtenção de materiais compósitos, nanocristalinos e amorfos (Benjamin, 1976; Suryanarayana, 2001). Além das aplicações citadas, essa técnica também é utilizada com o intuito de aumentar a reatividade química de uma mistura de pós para posterior tratamento térmico ou produção de compostos no próprio moinho por reações de combustão auto sustentáveis (SHS) (Takacs, 2002).

O mecanismo da moagem com alta energia de materiais dúcteis foi inicialmente proposto por Benjamin e Volin (1974). Nos primeiros estágios da moagem, as partículas dos pós são deformadas plasticamente assumindo formato achatado (flake). Com a continuidade do processo, há a predominância da soldagem a frio com a formação de agregados com microestrutura lamelar. No estágio intermediário há um aumento no encruamento e na resistência mecânica dos agregados, aumentando a probabilidade de fratura destes. Os estágios finais 
são caracterizados por um equilíbrio entre os eventos de soldagem e fratura, e pelo refinamento da microestrutura dos agregados, resultando na formação de soluções sólidas, intermetálicos e fases amorfas. Na FIG. 2 são apresentados esquematicamente os principais estágios do processo de moagem com alta energia de materiais dúcteis.

A produção de misturas com um elevado grau de dispersão e defeitos cristalinos, decorrente do mecanismo da moagem com alta energia, acarreta em um aumento na área de contato entre materiais dissimilares, promovendo uma melhoria na velocidade de difusão e na multiplicação de núcleos favoráveis para o início da reação. Esse tipo de processamento mecânico, no qual há a modificação das características do material quanto à sua reatividade química, é conhecido como ativação mecânica e permite a síntese de uma variedade de materiais, entre eles os compostos intermetálicos (Boldyrev, 1998; Takacs, 2002).

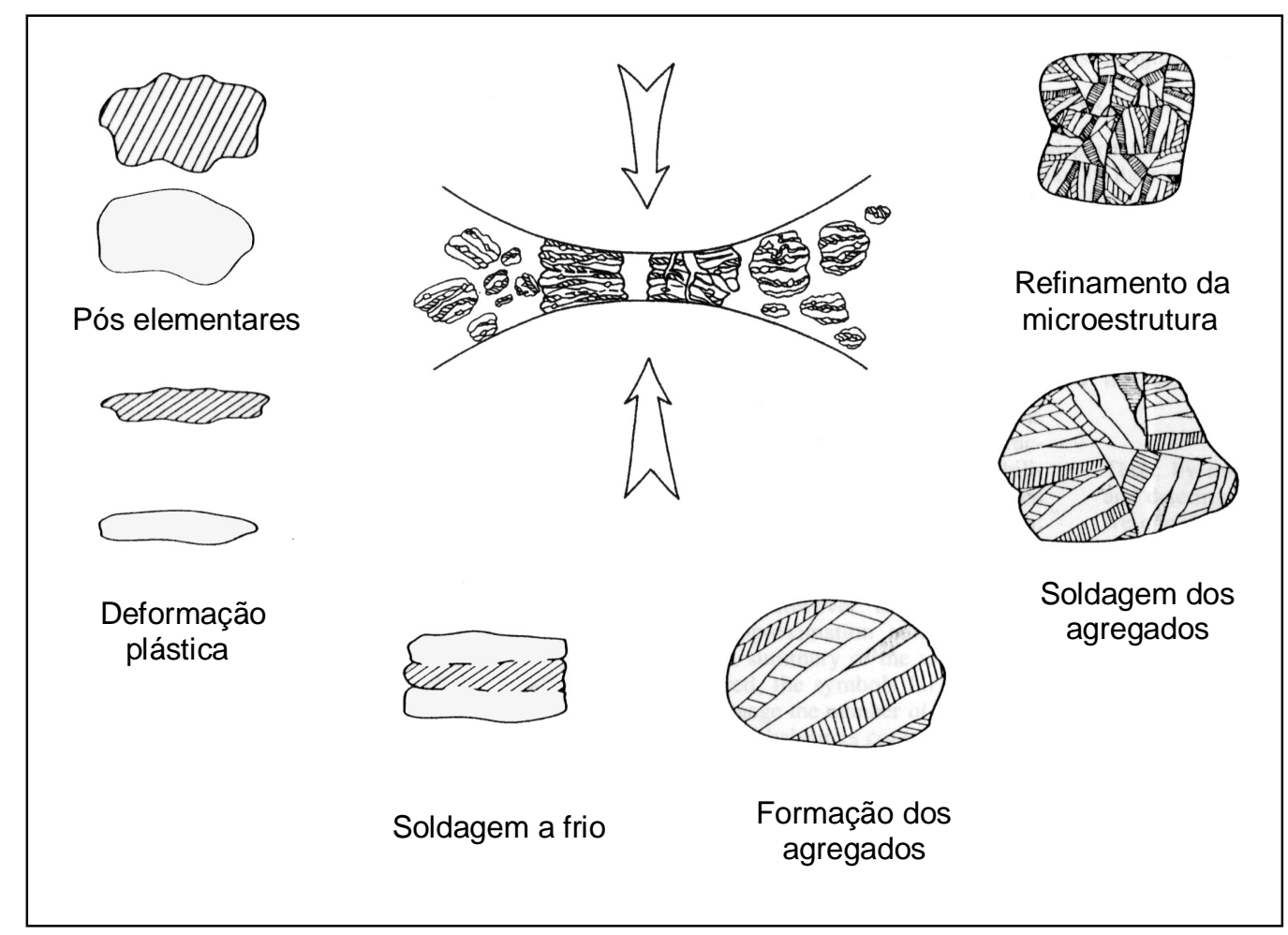

FIGURA 2 - Esquema dos principais estágios envolvidos no processo de moagem com alta energia de materiais dúcteis (Benjamin e Volin, 1974). 


\subsection{O processo de síntese por combustão mecanicamente ativada}

Os efeitos do tratamento dos pós elementares em moinhos de alta energia, com o intuito de ativá-los mecanicamente, no comportamento térmico de misturas $\mathrm{Nb75Al}$ reagidas por combustão, foram reportados por alguns autores. Gauthier et al. (1999), ao realizarem uma variação do processo SHS, associando a moagem com alta energia com esse modo de combustão (Mechanically Activated SHS), mais conhecido como MASHS, constataram uma diminuição na temperatura e no tempo de ignição em amostras de Nb75Al previamente processadas em moinho planetário. Leal Neto e Rocha (2001) também conduziram uma investigação no mesmo composto, a partir de misturas processadas em moinho agitador SPEX ${ }^{\circledR}$ 8000 em diferentes tempos de moagem (1, 2 e 3 horas) e reagidas posteriormente por combustão simultânea. Com os resultados obtidos pela análise térmica, constatou-se também uma diminuição na temperatura de ignição (em alguns casos, abaixo da temperatura de fusão do alumínio) das misturas mecanicamente ativadas. Tal fenômeno foi atribuído a um aumento na cinética da reação, em razão de uma maior dispersão e aumento da área de contato entre as partículas dos pós reagentes.

Obter materiais com uma estrutura altamente refinada e com um elevado grau de dispersão é possível em virtude dos eventos sucessivos de deformação, fratura, criação de novas superfícies e soldagem entre as partículas durante a moagem com alta energia (Benjamin, 1976). Para tal finalidade, um equilíbrio entre os eventos citados deve ser mantido. Na moagem de pós metálicos dúcteis, como o alumínio, observou-se que tal equilíbrio não ocorre naturalmente. $O$ mecanismo e o rendimento de moagem são prejudicados por uma excessiva soldagem entre as partículas dos pós, bem como por uma elevada aderência destas no meio de moagem (esferas e recipiente). Dentre as alternativas encontradas na literatura para minimizar esses efeitos e garantir uma eficiente ação de moagem, encontram-se a diminuição da temperatura do recipiente com nitrogênio líquido (moagem criogênica) e a adição de pequenas quantidades de compostos orgânicos, denominados de agentes controladores de processo (ACPs) à mistura de pós (Lai e Lü, 1998). Entre os dois procedimentos, verificouse que o emprego de tais agentes é mais difundido. 


\subsection{Os agentes controladores de processo (ACPs)}

$\mathrm{Na}$ literatura, há exemplos de uma variedade de ACPs que podem ser adicionados a uma mistura de pós durante a moagem, em quantidades que variam normalmente de 1 a $5 \%$ em peso em relação à carga total de pós. Esses aditivos podem ser empregados nos estados sólido, líquido ou gasoso, e são constituídos, notadamente, por compostos orgânicos. Entre os agentes mais comumente empregados, incluem-se: ácido esteárico $\left[\mathrm{CH}_{3}\left(\mathrm{CH}_{2}\right)_{16} \mathrm{COOH}\right.$, heptano $\left[\mathrm{CH}_{3}\left(\mathrm{CH}_{2}\right)_{5} \mathrm{CH}_{3}\right]$, hexano $\left[\mathrm{CH}_{3}\left(\mathrm{CH}_{2}\right)_{4} \mathrm{CH}_{3}\right]$, benzeno $\left[\mathrm{C}_{6} \mathrm{H}_{6}\right]$, parafina, etanol $\left[\mathrm{C}_{2} \mathrm{H}_{5} \mathrm{OH}\right]$, metanol $\left[\mathrm{CH}_{3} \mathrm{OH}\right]$, grafite $[\mathrm{C}]$, poli(etileno-glicol) $\left[\mathrm{H}\left(\mathrm{OCH}_{2} \mathrm{CH}_{2}\right)_{n} \mathrm{OH}\right]$ entre outros. Dentre eles, o ácido esteárico, o etanol, o metanol e o hexano são mais amplamente utilizados (Suryanarayana, 2001).

\subsubsection{Mecanismo proposto para a atuação dos ACPs durante a moagem}

O princípio de atuação dos ACPs durante a moagem, impedindo a soldagem excessiva entre as partículas e evitando a formação de agregados grosseiros e heterogêneos, ainda não é muito bem compreendido, carecendo de informações mais profundas com relação aos efeitos e mecanismos de interação desses agentes com pós metálicos dúcteis.

A explicação mais aceita foi proposta inicialmente por Suryanarayana (2001) e Lai e Lü (1998). Os autores enfatizam uma melhoria na eficiência de moagem pela adsorção dos agentes na superfície das partículas dos pós, impedindo o contato direto entre elas. A minimização da excessiva soldagem entre pós metálicos dúcteis ocorre por uma diminuição na "tensão superficial" dos agregados, aumentando a probabilidade de fratura destes (Suryanarayana, 2001; Lai e Lü, 1998). Uma vez que a energia requerida para reduzir o tamanho de partícula durante a moagem, E, é dada por:

$$
E=\gamma \cdot \Delta S
$$

onde $\gamma$ é a tensão superficial específica e $\Delta S$ representa um aumento na área de superfície dos pós, pode-se deduzir que uma redução em $\gamma$ resultará na geração 
de partículas mais finas para um mesmo tempo de moagem (Suryanarayana, 2001; Lai e Lü, 1998).

\subsubsection{Influência dos ACPs na moagem de materiais dúcteis}

Os efeitos produzidos por diferentes tipos de agentes (orgânicos ou inorgânicos) adicionados a uma mistura de pós durante a moagem têm sido reportados na literatura há algumas décadas.

Alguns trabalhos apresentam uma maior preocupação no que concerne à influência da quantidade e tipo de ACP na distribuição do tamanho de partícula dos pós moídos, na formação de fases e na cinética da reação (no caso da moagem reativa). Outros dão uma maior ênfase a uma possível decomposição desses agentes durante a moagem, liberando elementos que podem reagir com os pós, alterando assim as propriedades do produto final.

Zhang et al. (1999) estudaram os efeitos da quantidade (0,5 a 4,0\% em peso) e natureza do agente (ácido esteárico e poli(etileno-glicol)) na moagem de pós de Mg-Al durante 5 horas. Os resultados obtidos indicaram uma ação mais efetiva do ácido em relação ao poli(etileno-glicol) no que se refere ao tamanho de partícula e rendimento de moagem. Verificou-se também que o emprego de uma maior quantidade de agente resultou em pós mais finos e em uma microestrutura mais homogênea.

Em outros trabalhos (Lu e Zhang, 1999; Rocha et al., 1999), reportou-se que durante a moagem reativa, a quantidade do agente (no caso o ácido esteárico) pode afetar a cinética da reação, provocando uma diminuição na velocidade de formação da liga com a adição de uma maior quantidade de ACP. Essa observação foi atribuída a um aumento na distância de difusão entre as partículas, em razão da presença do agente na interface. Outra explicação fornecida para tal fato refere-se a uma possível diminuição de parte da energia mecânica necessária para o processo de soldagem, em conseqüência da absorção dessa energia pelo agente (Rocha et al., 1999).

Mais recentemente, Shaw et al. (2003) investigaram os efeitos da natureza (ácido esteárico e metanol) e quantidade dos agentes na elaboração mecânica 
(mechanical alloying) da liga de alumínio $\mathrm{Al}_{93} \mathrm{Fe}_{3} \mathrm{Ti}_{2} \mathrm{Cr}_{2}$ nanoestruturada. $\mathrm{O}$ estudo indicou que a manutenção do equilíbrio dos eventos de soldagem e fratura com a adição de uma maior quantidade de ACP, apesar de resultar em menores tamanhos de partícula, provocou uma diminuição na velocidade de formação de soluções sólidas, um menor refino microestrutural e um atraso na redução do tamanho dos cristalitos. Nesse trabalho, reportou-se que a adição de $1 \% \mathrm{em}$ massa de metanol foi mais efetiva na supressão da soldagem excessiva em relação à mesma quantidade de ácido esteárico. Tal afirmação foi exposta com base nos resultados de tamanho de cristalito e de parâmetro de rede do alumínio verificados após moagens com 960 minutos. Cristalitos com maiores dimensões foram obtidos com o uso do metanol. Pelo fato de tais parâmetros estarem correlacionados com o grau de deformação plástica das partículas e com a formação de soluções sólidas, os resultados encontrados são um indício de que o metanol acarreta maiores dificuldades ao processo de elaboração mecânica de ligas. O impedimento da soldagem excessiva foi atribuído às capacidades de adsorção e lubrificação desempenhadas pelas moléculas dos agentes. A adsorção do ACP na superfície das partículas impede o seu contato direto, corroborando a explicação fornecida por outros autores (Suryanarayana, 2001; Lai e Lü, 1998). Por outro lado, a lubrificação reduz o grau de deformação plástica das partículas durante o impacto, diminuindo, portanto, a velocidade na formação de soluções sólidas e o refinamento dos grãos (Shaw at al., 2003).

\subsubsection{Decomposição dos ACPs durante a moagem}

A hipótese de que uma fração dos compostos orgânicos utilizados como ACPs pode decompor-se durante a moagem, liberando, comumente, átomos de carbono $(\mathrm{C})$, oxigênio $(\mathrm{O})$ e hidrogênio $(\mathrm{H})$, foi investigada por alguns autores. A formação de compostos, notadamente carbetos e óxidos uniformemente dispersos no material, é atribuída à presença dos elementos citados no pó moído. A influência do hidrogênio na liga ainda não é bem conhecida. Acredita-se que esse elemento seja liberado para a atmosfera como hidrogênio molecular, ou sofra uma absorção nas partículas dos pós durante tratamento térmico posterior (Suryanarayana, 2001). Arias (1975) constatou também em seu trabalho que 
mesmo compostos orgânicos que apresentam alta estabilidade química (como os alcanos e o benzeno) podem reagir com pós metálicos durante a moagem. A severa deformação plástica, o aumento local de temperatura e a exposição das superfícies das partículas foram apontados como possíveis causadores do efeito observado.

Rocha et al. (1999) e Zhang et al. (1999), constataram que uma efetiva ação do agente é mantida até um certo tempo de moagem, ocorrendo uma diminuição da sua eficiência com o decorrer do tempo. Tal observação representa mais um indício de que os ACPs podem estar sofrendo uma decomposição ou um aprisionamento entre as lamelas do pó moído.

Frazier e Koczak (1987), estudando ligas de Ti-Al produzidas por metalurgia do pó, observaram que a moagem conduzida na presença de agentes orgânicos resultou na formação de carbetos e óxidos dispersos nos contornos de grão da liga. O aumento da resistência mecânica e diminuição da ductilidade do material foram atribuídos à presença de tais compostos. Outros trabalhos (Schneibel et al., 1992; Morris, D. e Morris M., 1990; Singer et al., 1980; Jangg et al., 1977) também reportaram a influência de impurezas provenientes dos agentes, comumente carbono e oxigênio, nas propriedades mecânicas de materiais processados em moinhos de alta energia.

Posteriormente, Lee e Kwun (1996), estudando o mesmo sistema (Ti-Al), verificaram uma alteração no mecanismo de formação de fases amorfas e metaestáveis conforme a quantidade $(0,3$ a $3,0 \%$ em peso) e tipo de agente (metanol e benzeno) empregado na moagem. Os resultados obtidos revelaram que a fase metaestável cúbica de face centrada (c.f.c.) formou-se após longo tempo de moagem (500 e 1000 horas) somente quando esta foi conduzida sem ACP ou na presença de benzeno, respectivamente. A supressão da fase c.f.c. na moagem com metanol foi atribuída à presença de átomos de oxigênio como impureza no pó moído.

Mais recentemente, Kleiner et al. (2005) reportaram uma decomposição gradual do ácido esteárico durante a moagem da mistura $\mathrm{Al}-\mathrm{TiO}_{2}$ em moinho planetário, contaminando-a com carbono. O grau de contaminação do pó foi avaliado por intermédio da análise termogravimétrica (ATG), mediante a 
associação entre as temperaturas de perda de massa das amostras moídas e do ácido esteárico puro. Os resultados encontrados mostraram que, para tempos de moagem entre 1 e 12 horas, a adição de uma maior quantidade de agente resultou em uma menor contaminação da mistura por carbono. A melhor lubrificação das partículas dos pós quando uma maior quantidade de agente é utilizada foi apresentada como fator redutor da decomposição do ácido, uma vez que menores temperaturas são geradas em cada colisão.

\subsubsection{Reatividade de compostos orgânicos com materiais metálicos e cerâmicos}

Nos últimos anos, alguns autores, em ramos de pesquisa diversos (Timsit et al., 1998; Chan e Lin, 1995; Underhill e Timsit, 1992), procuraram estudar o mecanismo de interação de alguns tipos de compostos orgânicos com materiais metálicos e cerâmicos. A reatividade do ácido esteárico com estes materiais foi investigada através da espectroscopia no infravermelho. Algumas análises por esta técnica indicaram que o ácido esteárico reage quimicamente com a camada de óxido na superfície do alumínio através do grupo carbonila $(\mathrm{C}=\mathrm{O})$. Os autores chegaram a essa conclusão por meio da observação da alteração na banda de absorção do grupo carbonila do ácido, de 1702 para $1560 \mathrm{~cm}^{-1}$ (Chan e Lin, 1995).

\subsubsection{Influência dos compostos orgânicos na reação de combustão}

Lin e Chung (2001), investigando a reação de síntese por combustão no modo SHS (sem ativação mecânica) de pós de nitreto de alumínio em atmosfera de nitrogênio, observaram que o tipo de aditivo utilizado (nesse caso para ajudar na difusão do nitrogênio no compactado de alumínio) pode afetar significativamente a evolução da reação, notando-se variações nos tempos e temperaturas de ignição registrados. Observou-se que aditivos contendo halogênios possuem um efeito catalítico na reação de combustão, atribuído à formação de $\mathrm{AIX}$ e $\mathrm{AIX}$. Tais compostos reagem mais facilmente com o nitrogênio em comparação ao alumínio metálico. No caso do emprego de aditivos como a 
uréia e o ácido esteárico, notou-se um melhor rendimento da reação, porém o compactado apresentou uma coloração acinzentada, possivelmente em razão da decomposição do composto orgânico utilizado.

Em um trabalho posterior, Rocha et al. (2003) investigaram os efeitos da quantidade de ACP (no trabalho em questão, o ácido esteárico) no tamanho de partícula, na microestrutura e na evolução da reação de síntese de misturas de $\mathrm{Nb75Al}$ e Ni25Al (proporção atômica), processadas em moinho agitador SPEX ${ }^{\circledR}$ 8000 e reagidas, posteriormente, por combustão simultânea. As quantidades de agente empregadas na moagem por 20 minutos do Ni25Al foram de 0,33 e 1,00\% em peso, enquanto que para o $\mathrm{Nb75Al}$ (moído por 1 hora) utilizou-se 0,50 e $1,00 \%$ em peso do ácido. A razão da variação entre as quantidades de ACP nas moagens das referidas composições deve-se às diferentes características de plasticidade apresentadas pela mistura dos pós desses dois sistemas. Observouse, para ambos os casos, um adiantamento na ignição da reação, mais

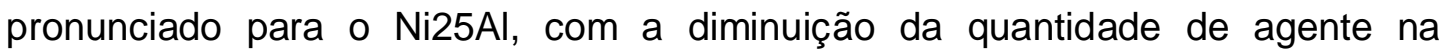
moagem. Embora o tamanho de partícula dos pós (observado na análise das micrografias eletrônicas de varredura) com uma menor quantidade de ácido não tenha resultado tão pequeno, tal observação foi explicada em razão de uma redução no número de partículas de nióbio e níquel isoladas, ocorrendo uma melhoria na cinética da reação, em virtude de um maior contato entre as partículas dos pós dos dois sistemas. Nesse estudo, observou-se também que maiores densidades foram obtidas com a realização de uma etapa prévia de desgaseificação no pó para a retirada do ácido.

Pelo exposto até o momento, torna-se evidente que a influência do tipo e quantidade de agente está muito além do que aquela relacionada somente ao tamanho de partícula e rendimento de moagem. Entretanto, observou-se uma carência nos estudos relativos a outros efeitos dos ACPs, sobretudo quanto à sua influência em reações de combustão. É nesse contexto que se insere este trabalho. 


\section{MATERIAIS E MÉTODOS}

\subsection{Planejamento de experimentos}

O estudo da influência das variáveis (tipo e quantidade) relativas ao ACP na síntese por combustão mecanicamente ativada do $\mathrm{NbAl}_{3}$ foi conduzido por meio da elaboração de planejamentos de experimentos do tipo composto central para dois fatores (variáveis). Esse tipo de planejamento permite descrever, com base nos dados resultantes dos experimentos, o comportamento do processo em estudo com a construção de modelos empíricos. É importante ressaltar que a modelagem empírica é baseada em modelos locais, descrevendo o sistema somente na região experimental investigada e impossibilitando, sem correr riscos, realizar previsões em regiões desconhecidas. Essa metodologia possibilita avaliar o grau de significância dos efeitos das diferentes variáveis sobre a resposta de interesse (no estudo em questão, a densidade relativa de pastilhas reagidas por combustão simultânea, após ativação mecânica dos pós constituintes em moinho de alta energia), bem como possíveis interações entre as variáveis. Em relação aos experimentos conduzidos pelo método clássico, em que apenas uma variável por vez é manipulada, o planejamento de experimentos proporciona uma redução significativa no número de ensaios e uma maior precisão e confiabilidade nos resultados obtidos. Entretanto, para que estes tenham validade estatística, os experimentos devem ser realizados aleatoriamente de modo a incluir a variabilidade total do processo e minimizar distorções nos dados decorrentes de variáveis das quais não se tem conhecimento ou não se pode controlar (Box et al., 1978; Barros Neto et al., 2002). Posteriormente, caso o modelo adotado possa ser considerado apto para realizar previsões (dentro da região investigada), é possível otimizar o resultado ou os resultados de interesse por meio da construção de superfícies de resposta.

Os planejamentos experimentais empregados neste estudo podem ser desmembrados em três partes: 
1. Parte fatorial ou cúbica, contendo um total de dois fatores (tempo de moagem e quantidade de ACP) estudados em dois níveis e totalizando quatro experimentos (pontos fatoriais ou cúbicos);

2. Parte axial (ou em estrela), formada por pontos rotacionados a $45^{\circ} \mathrm{em}$ relação à orientação de partida, resultando em quatro experimentos adicionais (pontos axiais);

3. Ensaios realizados no ponto central (normalmente caracteriza-se por ser a condição padrão de um sistema em estudo) com o intuito de fornecer uma medida do erro puro e estabilizar a variância da resposta prevista. No caso de planejamentos cuja parte axial é em estrela, é recomendável realizar de três a cinco ensaios repetidos no ponto central.

A representação geométrica de um planejamento do tipo composto central para dois fatores pode ser visualizada na FIG. 3.

Nas TAB. 1 e 2 são apresentados os níveis (em valores absolutos e codificados) das variáveis investigadas e a matriz de planejamento com os níveis das variáveis codificados, respectivamente. Foi elaborado um planejamento de experimentos para cada tipo de ACP, estudando-se a influência das variáveis tempo de moagem e quantidade de agente sobre a densidade relativa (porcentagem em relação à densidade teórica do composto intermetálico $\mathrm{NbAl}_{3}$ ) de pastilhas compactadas e reagidas por combustão simultânea. A variância e o desvio padrão dos ensaios foram determinados por meio de repetições na condição padrão, denominada de ponto central, a saber: tempo de moagem: 60 minutos; quantidade de ACP: 1,0\%.

Os resultados obtidos por meio dos planejamentos experimentais foram analisados com o auxílio do software de estatística MINITAB, versão 14. 


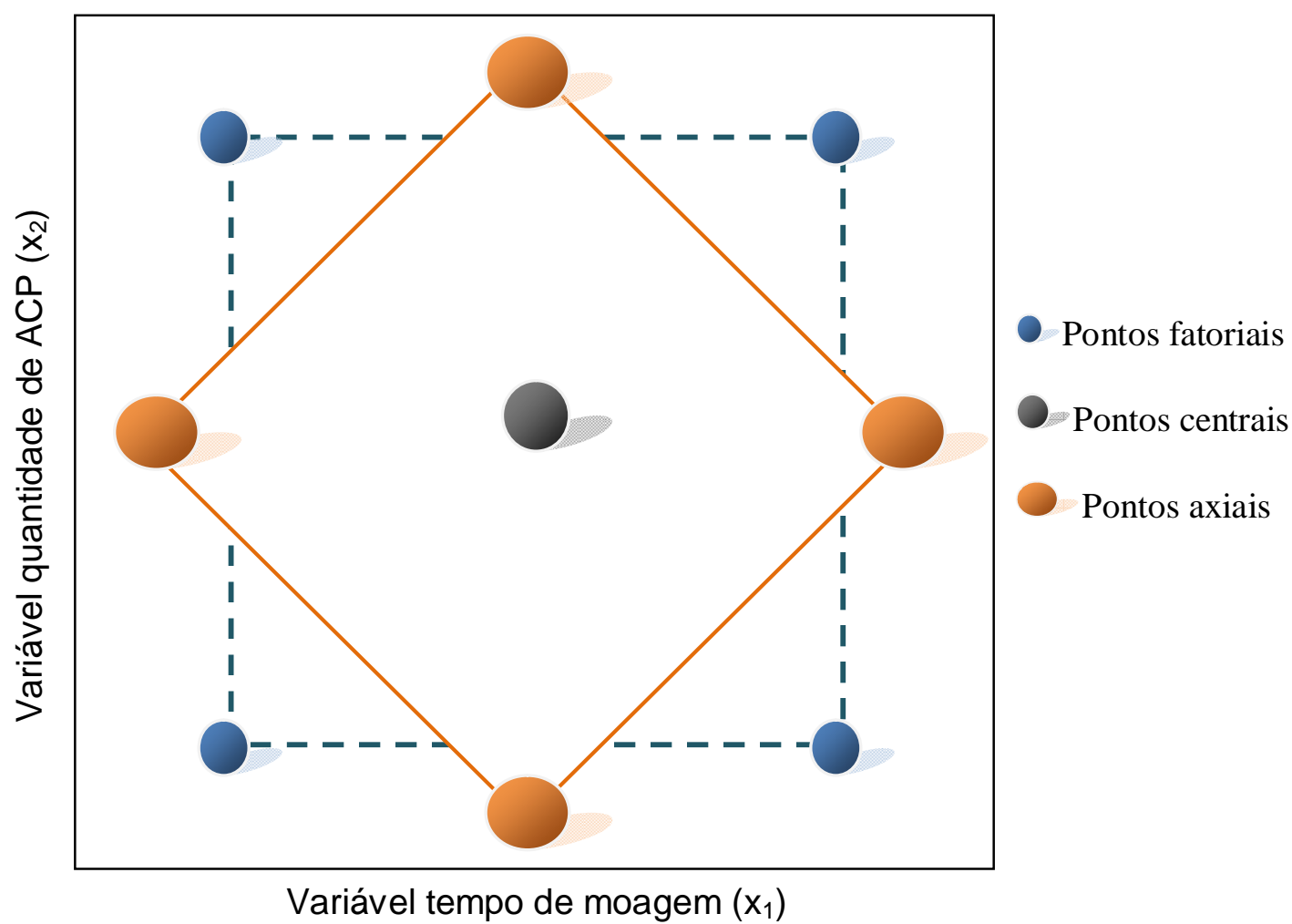

FIGURA 3 - Representação geométrica de um planejamento composto central para dois fatores (Barros Neto et al., 2002).

TABELA 1 - Níveis das variáveis investigadas para cada ACP.

\begin{tabular}{|c|c|c|c|c|c|}
\cline { 2 - 6 } \multicolumn{1}{c|}{} & \multicolumn{2}{c|}{ Parte fatorial } & Ponto central & \multicolumn{2}{c|}{$\begin{array}{c}\text { Parte axial } \\
\text { (em estrela) }\end{array}$} \\
\hline Variáveis & $\begin{array}{c}\text { Nível } \\
\text { inferior }\end{array}$ & $\begin{array}{c}\text { Nível } \\
\text { superior }\end{array}$ & $\begin{array}{c}\text { Condição } \\
\text { padrão }\end{array}$ & $\begin{array}{c}\text { Nível } \\
\text { inferior }\end{array}$ & $\begin{array}{r}\text { Nível } \\
\text { superior }\end{array}$ \\
\hline $\begin{array}{c}\mathrm{x}_{1} \text { : tempo de } \\
\text { moagem (minutos) }\end{array}$ & 30 & 90 & 60 & 18 & 102 \\
\hline $\begin{array}{c}\mathrm{x}_{2} \text { : quantidade de } \\
\text { ACP (\%) }\end{array}$ & 0,5 & 1,5 & 1,0 & 0,3 & 1,7 \\
\hline \begin{tabular}{c}
$\mathrm{x}_{1} \mathrm{e} \mathrm{x}_{2}$ codificadas \\
\hline
\end{tabular} & $(-1)$ & $(+1)$ & $(0)$ & $(-\sqrt{ } 2)$ & $(+\sqrt{ } 2)$ \\
\hline
\end{tabular}


TABELA 2 - Matriz de planejamento com os níveis das variáveis (tempo de moagem e quantidade de ACP: $x_{1}$ e $x_{2}$, respectivamente) codificados.

\begin{tabular}{|c|c|c|c|}
\hline $\begin{array}{c}\text { Planejamento } \\
\text { composto central }\end{array}$ & $\begin{array}{l}\text { Ensaios } \\
\text { realizados }\end{array}$ & $\begin{array}{c}\text { Tempo de } \\
\text { moagem } \\
\left(x_{1}\right)\end{array}$ & $\begin{array}{l}\text { Quantidade de } \\
\qquad \begin{array}{c}\text { ACP } \\
\left(x_{2}\right)\end{array}\end{array}$ \\
\hline \multirow{4}{*}{ Pontos fatoriais } & 1 & -1 & -1 \\
\hline & 2 & +1 & -1 \\
\hline & 3 & -1 & +1 \\
\hline & 4 & +1 & +1 \\
\hline \multirow{4}{*}{ Pontos axiais } & 5 & $-\sqrt{2}$ & 0 \\
\hline & 6 & 0 & $\sqrt{ } 2$ \\
\hline & 7 & $\sqrt{2}$ & 0 \\
\hline & 8 & 0 & $-\sqrt{2}$ \\
\hline \multirow{5}{*}{ Pontos centrais } & 9 & 0 & 0 \\
\hline & 10 & 0 & 0 \\
\hline & 11 & 0 & 0 \\
\hline & 12 & 0 & 0 \\
\hline & 13 & 0 & 0 \\
\hline
\end{tabular}

Os planejamentos de experimentos, por meio da utilização de algumas ferramentas e princípios da estatística, permitem extrair do sistema em estudo uma grande quantidade de informações realizando um número mínimo de ensaios. Essas ferramentas podem ser utilizadas por meio dos softwares de estatística disponíveis no mercado. Entretanto, vale salientar que o conhecimento científico prévio do processo em estudo é insubstituível e deve ser analisado conjuntamente com os métodos estatísticos.

No presente estudo, procurou-se extrair as seguintes informações dos planejamentos experimentais: 
1. Propor um modelo empírico para descrever o processo em estudo;

2. Checar e avaliar a validade estatística do modelo empírico proposto;

3. Identificar os efeitos principais para cada ACP, por meio da determinação do grau de significância das variáveis (tempo de moagem e quantidade de ACP) sobre a densidade relativa de pastilhas reagidas de $\mathrm{NbAl}_{3}$, caso o modelo adotado seja considerado válido;

4. Verificar interações entre as variáveis;

5. Construir superfícies de resposta para os modelos empíricos considerados estatisticamente válidos.

Os conceitos principais utilizados para a interpretação dos resultados obtidos nos planejamentos compostos centrais, principalmente no que concerne à avaliação da qualidade do ajuste do modelo e à determinação dos efeitos principais e interações entre as variáveis, estão descritos no anexo.

\subsection{Preparação das misturas mecanicamente ativadas}

Neste trabalho, foram utilizados pós de nióbio (produzido por hidretaçãomoagem-desidretação) e alumínio (obtido por atomização a gás) de origem nacional, nas faixas granulométricas de -325 \# e com graus de pureza de 99,0\% e 99,7\%, respectivamente. O pó de nióbio $(\mathrm{Nb})$ foi fornecido pela EEL (Escola de Engenharia de Lorena) e o pó de alumínio (Al) pela Alcoa. Foram investigados quatro agentes controladores de processo, representantes de três grupos funcionais, a saber: ácido esteárico (ácido carboxílico), etanol (álcool), metanol (álcool) e ciclohexano (cicloalcano), nos graus de pureza de 95,0\% para o ácido esteárico e acima de 99,5\% para os demais agentes. A escolha de cada ACP foi realizada levando-se em conta as seguintes considerações: publicação anterior do grupo de pesquisa do Laboratório de Intermetálicos (Rocha et al., 2003) e literatura disponível sobre o assunto (ácido esteárico e metanol), estabilidade química do agente (ciclohexano), facilidade e disponibilidade comercial (etanol). $\mathrm{Na}$ TAB. 3 são apresentadas algumas propriedades físicas dos agentes empregados neste estudo. Para cada batelada de $10 \mathrm{~g}$ de mistura de Nb75Al 
(correspondente à estequiometria do composto intermetálico $\mathrm{NbAl}_{3}$ ), os diferentes tipos de ACPs foram adicionados nas proporções pré-determinadas nos planejamentos de experimentos.

TABELA 3 - Propriedades físicas dos ACPs utilizados neste estudo (Merck Index, 1983).

\begin{tabular}{|c|c|c|c|c|}
\hline ACP & $\begin{array}{c}\text { T. }\left({ }^{\circ} \mathrm{C}\right) \text { de } \\
\text { fusão } \\
\text { a } 1 \text { atm. }\end{array}$ & $\begin{array}{l}\text { T. }\left({ }^{\circ} \mathrm{C}\right) \text { de } \\
\text { ebulição } \\
\text { a } 1 \text { atm. }\end{array}$ & $\begin{array}{c}\text { Densidade } \\
\text { a } 20^{\circ} \mathrm{C} \\
\left(\mathrm{g} / \mathrm{cm}^{3}\right)\end{array}$ & $\begin{array}{l}\text { Estrutura } \\
\text { Molecular }\end{array}$ \\
\hline $\begin{array}{l}\text { Ácido esteárico } \\
\left(\mathrm{CH}_{3}\left(\mathrm{CH}_{2}\right)_{16} \mathrm{COOH}\right)\end{array}$ & $69-70$ & 383 & 0,94 & 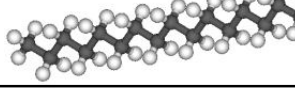 \\
\hline $\begin{array}{c}\text { Etanol } \\
\left(\mathrm{CH}_{3} \mathrm{CH}_{2} \mathrm{OH}\right)\end{array}$ & $-114,1$ & 78,5 & 0,79 & \\
\hline $\begin{array}{l}\text { Metanol } \\
\left(\mathrm{CH}_{3} \mathrm{OH}\right)\end{array}$ & $-97,8$ & 64,7 & 0,79 & \\
\hline $\begin{array}{l}\text { Ciclohexano } \\
\qquad\left(\mathrm{C}_{6} \mathrm{H}_{12}\right)\end{array}$ & 6 & 81 & 0,78 & \\
\hline
\end{tabular}


As moagens com alta energia foram conduzidas em um moinho agitador $\left(\right.$ SPEX $\left.{ }^{\circledR} 8000\right)$ refrigerado a ar. As variáveis efetivamente investigadas foram às relativas ao ACP (tipo e quantidade), e o tempo de moagem. Esta última (considerada a principal variável de moagem) foi escolhida com o intuito de avaliar sua interação com a natureza e quantidade dos agentes utilizados. O carregamento e o descarregamento das amostras foram realizados no interior de uma caixa de luvas (glove box) em atmosfera inerte (argônio). O tempo mínimo utilizado para a retirada dos pós moídos do interior da caixa de luvas foi de 60 minutos. $\mathrm{Na}$ TAB. 4, podem ser visualizadas as condições de moagem empregadas no processo. As ilustrações relativas ao moinho e ao meio de moagem estão apresentadas na FIG. 4.

TABELA 4 - Parâmetros de moagem empregados no processo.

\begin{tabular}{|c|c|}
\hline Parâmetros de moagem & Condições adotadas \\
\hline Tipo de moinho & Agitador (SPEX ${ }^{\circledR}$ 8000) \\
\hline Recipiente de moagem & Aço inoxidável endurecido (ABNT 420) \\
\hline Esferas de moagem & Aço inoxidável austenítico (ABNT 304L) \\
\hline Volume do copo (cm ${ }^{3}$ ) & 7,14 \\
\hline Diâmetro das esferas (mm) & 67 \\
\hline Quantidade de esferas & Argônio comercial \\
\hline Razão de carga (em massa): esfera-pó & $10: 1$ \\
\hline Atmosfera de moagem & AB \\
\hline
\end{tabular}




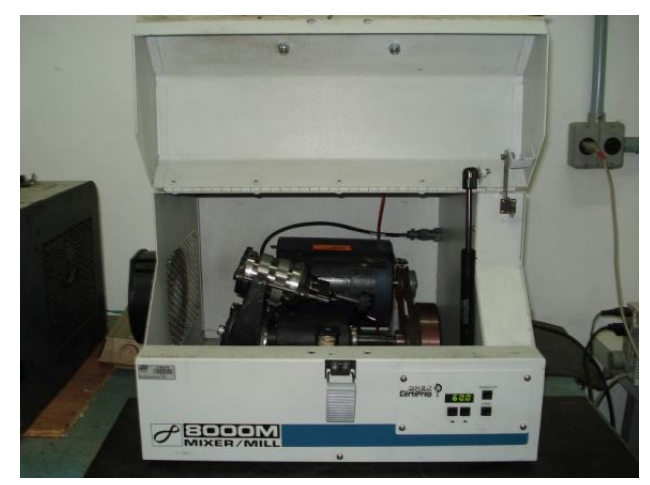

(a) Moinho agitador SPEX ${ }^{\circledR} 8000$

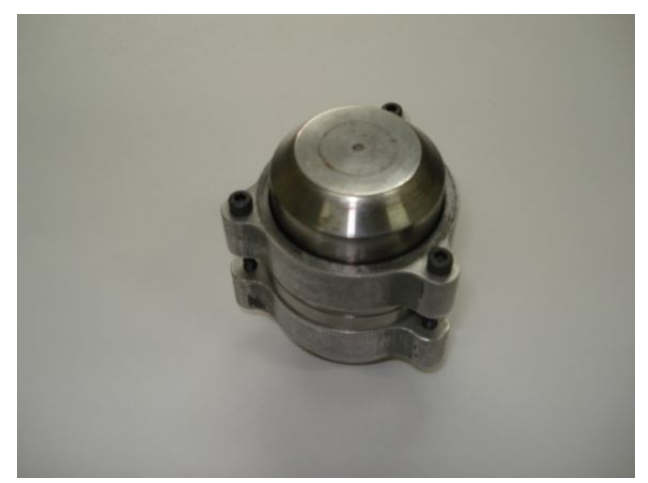

(c) Recipiente de moagem

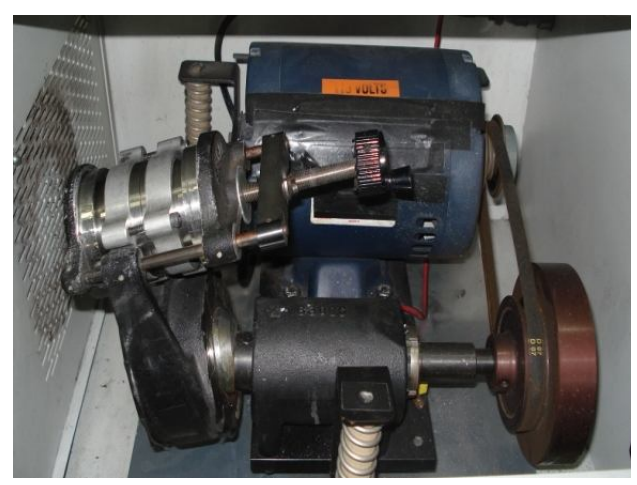

(b) Detalhe do interior do moinho

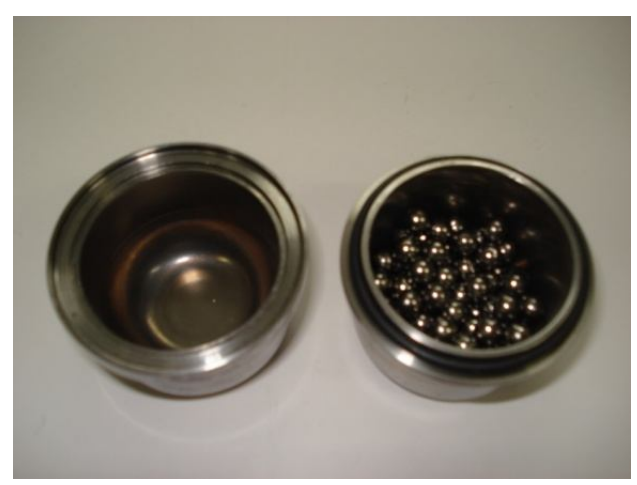

(d) Detalhe do interior do recipiente contendo as esferas de moagem

FIGURA 4-llustrações do moinho agitador e do recipiente utilizados nas moagens com alta energia.

\subsubsection{Caracterização das misturas após moagem com alta energia}

A forma e o tamanho das partículas das misturas moídas, bem como a dispersão e microestrutura dos agregados, foram caracterizados em microscópios eletrônicos de varredura, marcas Philips e Jeol JSM, modelos X30 e 5600LV, respectivamente. As amostras foram preparadas por dois métodos distintos, conforme a finalidade da análise: forma e tamanho das partículas, ou dispersão e microestrutura dos agregados. No primeiro caso, as amostras foram dispersas em um substrato aderido ao porta-amostra e submetidas à deposição de um filme fino de ouro, proporcionando uma melhor resolução e contraste da imagem. Para a segunda finalidade, as amostras foram misturadas à resina epóxi e embutidas em baquelite para posterior preparação metalográfica. Após lixamento e polimento, as 
amostras foram recobertas com um filme fino de carbono e analisadas utilizando os sinais dos elétrons secundários e retroespalhados.

A distribuição do tamanho de partícula das misturas moídas foi avaliada por meio da técnica de difração de laser em equipamento Cilas ${ }^{\circledR}$, modelo 1064 , com faixa analítica de 0,04 a $500 \mu \mathrm{m}$. As análises foram realizadas em meio líquido (água), utilizando pirofosfato de sódio como agente dispersante.

A verificação da formação de fases previamente à reação foi realizada, de forma qualitativa, por meio de ensaios de difração de raios $X$ em um difratômetro Rigaku, modelo Multiflex, utilizando a radiação $\mathrm{K}_{\alpha}$ do cobre (comprimento de onda de $1,5406 \AA$ ). As análises foram realizadas na faixa angular $(2 \theta)$ entre 10 e $80^{\circ}$, com passo de $0,02^{\circ}$ e tempo de contagem por passo de 1 segundo.

A análise de imagem quantitativa foi realizada nos pós moídos com 0 auxílio do software Quantikov (Pinto, 1996). Essa análise teve como principal objetivo avaliar o grau de ativação mecânica das misturas moídas, por meio da determinação da fração volumétrica das partículas de nióbio não associadas com o alumínio, formando agregados. Para tal análise, as micrografias eletrônicas de varredura (utilizando os sinais dos elétrons retroespalhados) foram obtidas em 20 regiões distintas, em um aumento de $100 \times$.

Com o intuito de adquirir uma melhor compreensão no mecanismo de atuação dos ACPs durante a moagem com alta energia, algumas condições foram analisadas por espectroscopia no infravermelho, utilizando equipamento da marca Perkin-Elmer, modelo Spectrum BX com ATR Miracle.

As espectroscopias de absorção e reflexão no infravermelho constituem uma ferramenta versátil comumente utilizada na identificação qualitativa e, por vezes, quantitativa de estruturas e espécies orgânicas. No que tange somente à espectroscopia de reflexão no infravermelho (técnica empregada neste trabalho), esta é especialmente utilizada para a obtenção imediata de espectros de reflexão em amostras sólidas (pós metálicos, filmes poliméricos, fibras entre outros), dispensando a necessidade de uma preparação laboriosa. A reflexão da radiação pode ser obtida por meio da utilização de um dispositivo que permite obter espectros de refletância total atenuada (ATR). Essa técnica é muito útil no fornecimento de informações sobre as propriedades da superfície de um material. 
A região mais amplamente investigada corresponde ao infravermelho médio que compreende o intervalo de número de onda de 4000 a $670 \mathrm{~cm}^{-1}$ (ou os comprimentos de onda de 2,5 a $15 \mu \mathrm{m}$ ). Os espectros no infravermelho são oriundos da variação no momento de dipolo das moléculas ocasionada por movimentos vibracionais e rotacionais em torno das ligações químicas. As vibrações moleculares podem ser classificadas em duas categorias: vibração de estiramento e vibração de deformação angular. A primeira envolve uma variação contínua na distância interatômica ao longo do eixo da ligação entre átomos. Por sua vez, a vibração de deformação angular é caracterizada pela variação do ângulo entre duas ligações (Skoog et al., 2002). As análises realizadas por essa técnica tiveram o intuito somente de tentar identificar qualitativamente os ACPs utilizados na moagem com alta energia, ou uma possível interação destes com os pós de nióbio e alumínio, sem ter a pretensão de estudar com profundidade todas as informações que podem ser extraídas a partir dos espectros no infravermelho, especialmente com o auxílio da quimiometria.

\subsection{Compactação das misturas moídas}

Pastilhas cilíndricas das misturas moídas $(4 \mathrm{~g})$ foram compactadas uniaxialmente em matriz flutuante $(\varnothing=14 \mathrm{~mm})$, lubrificada com estearato de zinco. A carga foi aplicada por uma máquina universal de ensaios mecânicos, marca Instron, modelo $4400 \mathrm{R}$, a uma velocidade de compactação de $3 \mathrm{~mm} / \mathrm{min}$. A altura das pastilhas foi controlada de forma a manter a densidade a verde em torno de 74,0 $\pm 1,0 \%$ da densidade teórica da mistura de $\mathrm{Nb75Al}\left(4,27 \mathrm{~g} / \mathrm{cm}^{3}\right)$, para as diferentes condições. Os valores de densidade a verde foram obtidos a partir da determinação das massas e dimensões das pastilhas, assumindo-se geometria cilíndrica. 


\subsection{Reações de combustão}

As reações de combustão foram conduzidas em um forno resistivo tubular sob vácuo (pressão de $10^{-4} \mathrm{~Pa}$ ), dotado de controle programável de aquecimento. As pastilhas compactadas foram inseridas em um tubo de quartzo selado em uma das extremidades. Na primeira parte do ciclo térmico, as pastilhas foram aquecidas a uma taxa de $5{ }^{\circ} \mathrm{C} / \mathrm{min}$ até um patamar isotérmico a $400{ }^{\circ} \mathrm{C}$ por 240 minutos (etapa de desgaseificação para a retirada do ACP e/ou de outras impurezas voláteis). Findo esse tempo, o reaquecimento foi feito a uma taxa de $30{ }^{\circ} \mathrm{C} / \mathrm{min}$ até 0 final da reação. O resfriamento das pastilhas, após a reação, ocorreu sob vácuo $\left(10^{-4} \mathrm{~Pa}\right)$. As temperaturas de ignição foram monitoradas por intermédio de um termopar tipo $\mathrm{S}$, recoberto com lama de alumina (na menor quantidade possível), localizado na superfície das pastilhas. A escolha deste tipo de termopar foi feita em virtude da sua faixa de operação, a qual é compatível com as elevadas temperaturas atingidas no momento da reação (aproximadamente $1400{ }^{\circ} \mathrm{C}$ na superfície da pastilha). O recobrimento da ponta do termopar com lama de alumina, realizado manualmente, foi necessário em razão da reatividade da platina com o alumínio no estado líquido. Na FIG. 5 são apresentadas ilustrações do posicionamento do termopar na pastilha compactada. Os registros de tempo-temperatura foram obtidos por um sistema de aquisição operando a uma velocidade de varredura de $10 \mathrm{~Hz}$ (10 medidas/segundo) após o patamar de desgaseificação.

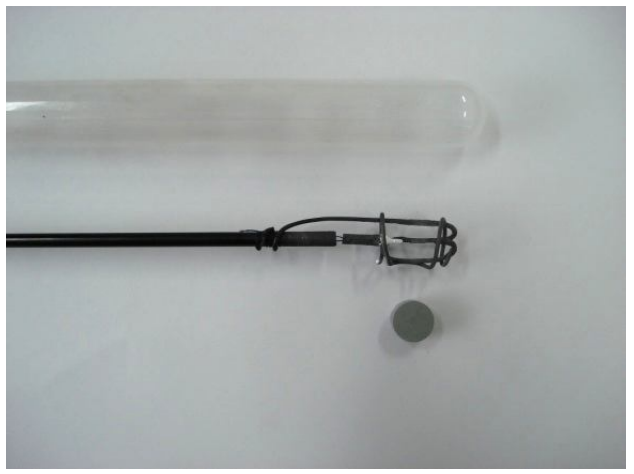

(a)

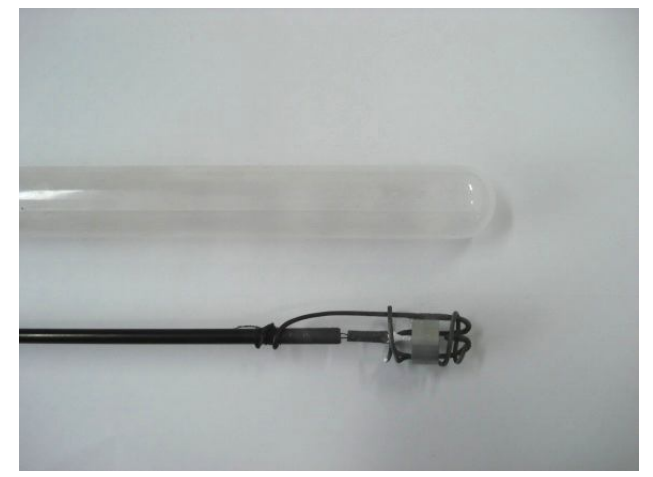

(b)

FIGURA 5 - llustrações dos componentes que são inseridos no interior do forno. (a) Tubo de quartzo, termopar recoberto com lama de alumina e pastilha compactada. (b) Posicionamento do termopar na superfície da pastilha. 
Nas misturas contendo adições de ACP acima de 1,0\%, houve a necessidade de realizar uma etapa prévia de desgaseificação no pó antes da compactação, visando minimizar a evolução de gases no momento da reação, fato que é prejudicial às densidades das pastilhas reagidas. O ciclo térmico adotado para esse tratamento de desgaseificação no pó consistiu em um aquecimento a uma taxa de $5^{\circ} \mathrm{C} / \mathrm{min}$ até um patamar isotérmico a $300{ }^{\circ} \mathrm{C}$ por 30 minutos, seguido de um reaquecimento a uma taxa de $1^{\circ} \mathrm{C} / \mathrm{min}$ até um patamar isotérmico a $400{ }^{\circ} \mathrm{C}$ por 60 minutos. O resfriamento do pó, tal como descrito no resfriamento da pastilha, ocorreu no interior do forno, a partir de seu desligamento, sempre sob vácuo.

\subsubsection{Caracterização das pastilhas reagidas}

As densidades das pastilhas reagidas foram determinadas por medidas geométricas e pelo método de Arquimedes, segundo a norma ASTM C 373-88 com $1 \mathrm{~h}$ de ebulição.

A caracterização microestrutural, a exemplo da realizada com as misturas moídas, foi feita em microscópios eletrônicos de varredura, marcas Philips e Jeol JSM, modelos X30 e 5600LV, respectivamente. As pastilhas reagidas foram cortadas longitudinalmente e embutidas em baquelite. Após preparação metalográfica, as amostras receberam a deposição de um filme fino condutor de carbono. As informações foram obtidas por meio dos elétrons secundários e retroespalhados.

A caracterização da fase majoritária e de possíveis produtos de reação foi realizada, qualitativamente, pela espectroscopia por energia dispersiva (EDS) em microscópio eletrônico de varredura e por meio da difração de raios $X$, utilizando a radiação $\mathrm{K}_{\alpha}$ do cobre (comprimento de onda de 1,5406 $\AA$ ) e as faixas angulares (20) entre 10 e $80^{\circ}$, com passo de $0,02^{\circ}$ e tempo por passo de 1 segundo.

Em algumas condições de moagem, observou-se nas micrografias eletrônicas de varredura, a formação de uma segunda fase, além do $\mathrm{NbAl}_{3}$. Nessas pastilhas, foram realizadas análises de imagem quantitativa, com o intuito de medir a fração volumétrica dessa outra fase. Tais análises de imagem, a 
exemplo dos pós moídos, também foram realizadas utilizando-se o software Quantikov (Pinto, 1996). Nesses casos, foram obtidas micrografias eletrônicas de varredura (utilizando os sinais dos elétrons retroespalhados) em 10 regiões distintas, considerando uma magnificação de $300 \times$.

O comportamento térmico das pastilhas reagidas foi avaliado mediante a análise dos perfis de temperatura obtidos na segunda parte do ciclo térmico até o final da reação. A temperatura de ignição registrada durante o processo foi estimada graficamente por meio da intersecção da tangente representada na região de fusão do alumínio (que antecede o início da reação) e na região onde ocorre a explosão térmica (momento da reação), conforme ilustrado na FIG. 6. O

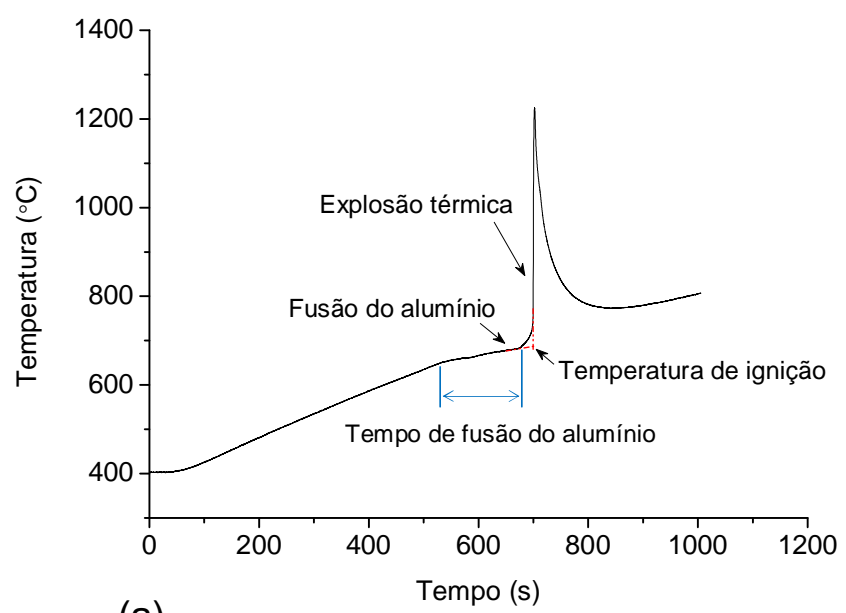

(a)

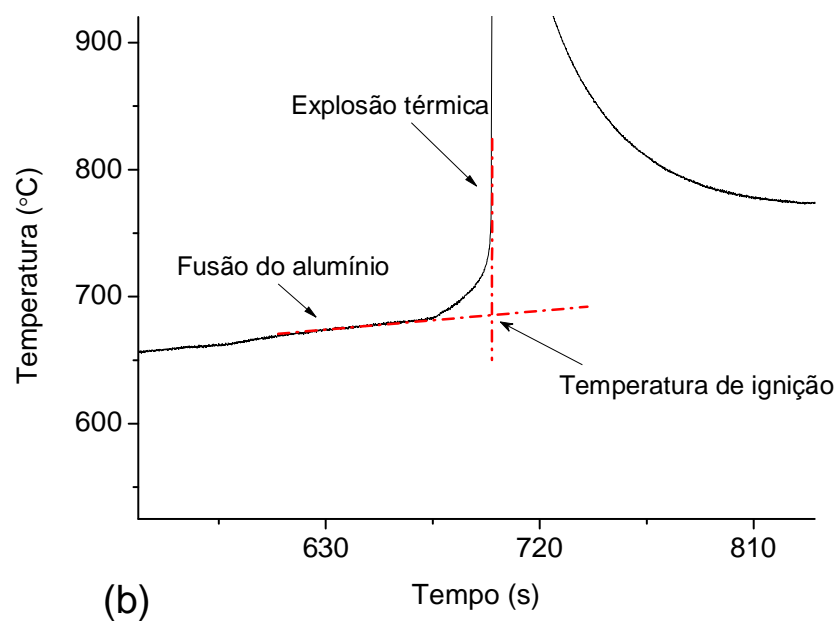

FIGURA 6 - Metodologia empregada para a estimativa da temperatura de ignição. (a) Exemplo de perfil de temperatura registrado pelo sistema de aquisição. (b) Detalhe da região indicada em (a). 
início da fusão do alumínio foi estimado por meio da intersecção das retas, obtidas por regressão linear, em trechos da curva de aquecimento antes e durante o processo de fusão. A determinação do final da fusão do alumínio baseou-se no aumento da taxa de aquecimento após o processo de fusão (observado por meio da alteração na inclinação da curva) (FIG. 6). 


\section{RESULTADOS E DISCUSSÃO}

\subsection{Planejamento de experimentos}

Os resultados obtidos nos planejamentos compostos centrais realizados para cada tipo de ACP estão descritos nos itens a seguir. A expressão geral adotada para os planejamentos pode ser representada pela equação 5.1.

$$
\hat{y}=b_{0}+b_{1} x_{1}+b_{2} x_{2}+b_{11} x_{1}^{2}+b_{22} x_{2}^{2}+b_{12} x_{1} x_{2}
$$

onde $\hat{y}$ é a resposta prevista pelo modelo, $b$ representa os coeficientes ou parâmetros do modelo e $x$ são os níveis das variáveis estudadas, ou seja, o tempo de moagem $\left(x_{1}\right)$ e a quantidade de $\operatorname{ACP}\left(x_{2}\right)$.

\subsubsection{Planejamento composto central para o ácido esteárico}

$\mathrm{Na}$ TAB. 5 são apresentados os valores de densidade relativa de pastilhas reagidas de $\mathrm{NbAl}_{3}$ (resposta de interesse), obtidos neste primeiro planejamento, juntamente com a ordem de execução dos ensaios. A representação geométrica dos resultados e das condições estudadas pode ser observada na FIG. 7.

A avaliação da qualidade do ajuste do modelo e a determinação das variáveis significativas podem ser visualizadas nas TAB. 6 a 8. Os cálculos matemáticos foram realizados no software de estatística MINITAB, versão 14. 
TABELA 5 - Resultados do planejamento composto central para o ácido esteárico. Os níveis das variáveis estão codificados.

\begin{tabular}{|c|c|c|c|c|c|}
\hline Planejamento & $\begin{array}{l}\text { Ordem } \\
\text { padrão }\end{array}$ & $\begin{array}{c}\text { Ordem dos } \\
\text { ensaios } \\
\text { realizados }\end{array}$ & $\begin{array}{c}\text { Tempo de } \\
\text { moagem } \\
\left(x_{1}\right)\end{array}$ & $\begin{array}{c}\text { Quantidade } \\
\text { de ACP } \\
\left(\mathrm{x}_{2}\right)\end{array}$ & $\begin{array}{c}\text { Densidade } \\
\text { relativa } \\
\left(\% d_{t}\right)^{*}\end{array}$ \\
\hline \multirow{4}{*}{$\begin{array}{l}\text { Pontos } \\
\text { fatoriais }\end{array}$} & 1 & 3 & -1 & -1 & 95,88 \\
\hline & 2 & 6 & +1 & -1 & 72,90 \\
\hline & 3 & 9 & -1 & +1 & 82,94 \\
\hline & 4 & 7 & +1 & +1 & 83,84 \\
\hline \multirow{4}{*}{ Pontos axiais } & 5 & 5 & $-\sqrt{2}$ & 0 & 78,19 \\
\hline & 6 & 8 & 0 & $\sqrt{ } 2$ & 92,62 \\
\hline & 7 & 11 & $\sqrt{2}$ & 0 & 74,48 \\
\hline & 8 & 10 & 0 & $-\sqrt{ } 2$ & 81,94 \\
\hline \multirow{5}{*}{$\begin{array}{l}\text { Pontos } \\
\text { centrais }\end{array}$} & 9 & 1 & 0 & 0 & 90,93 \\
\hline & 10 & 4 & 0 & 0 & 87,68 \\
\hline & 11 & 2 & 0 & 0 & 88,64 \\
\hline & 12 & 13 & 0 & 0 & 88,91 \\
\hline & 13 & 12 & 0 & 0 & 90,88 \\
\hline
\end{tabular}

\footnotetext{
${ }^{*} \mathrm{~d}_{\mathrm{t}}=4,54 \mathrm{~g} / \mathrm{cm}^{3}$ (densidade teórica do $\mathrm{NbAl}_{3}$ ).
} 


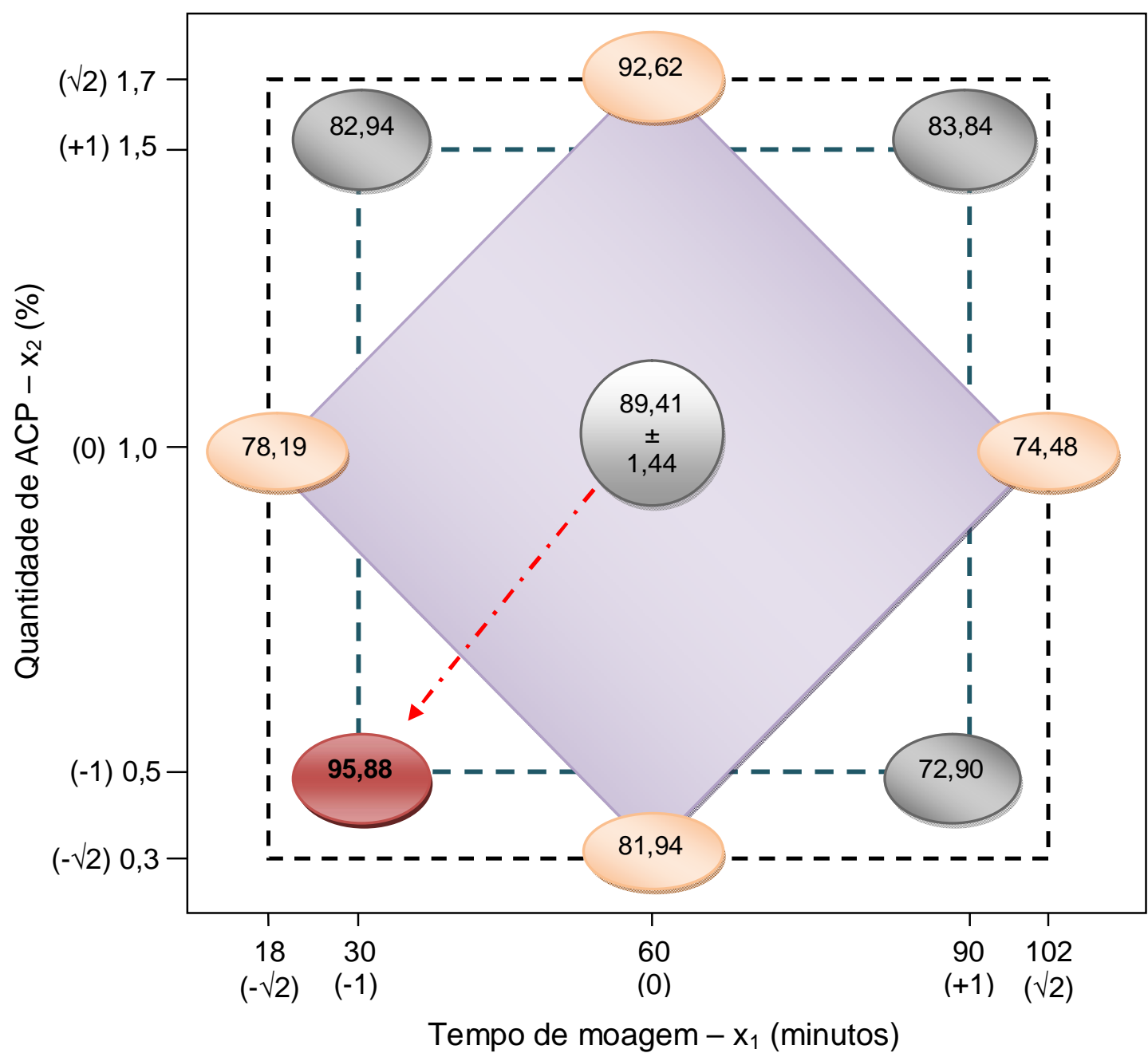

FIGURA 7 - Representação geométrica dos resultados obtidos no planejamento composto central para o ácido esteárico. A seta vermelha indica a direção para a otimização da resposta.

\section{Avaliação da qualidade do ajuste do modelo}

A qualidade do ajuste do modelo, em um primeiro momento, foi avaliada numericamente pela análise de variância (ANOVA) apresentada na TAB. 6 e, graficamente, pelo exame dos resíduos mostrados na FIG. 8. A porcentagem de variação explicada pelo modelo $\left(R^{2}\right)$ foi de $85,1 \%$. Esse valor não deve ser comparado com $100 \%$ e sim com a porcentagem máxima de variação explicável (no caso, 98,6\%). Esta última não considera a contribuição do erro puro, uma vez que a sua soma quadrática $\left(\mathrm{SQ}_{\mathrm{ep}}\right)$ não pode ser reproduzida pelo modelo. $\mathrm{A}$ aplicação do teste $F$ (para um intervalo de confiança de 95\%) para a falta de 
ajuste revelou um valor de $F_{\text {calc. }}$ superior ao valor de $F_{\text {tab. }}$. Isso equivale a dizer que a pequena falta de ajuste verificada para o modelo impossibilita, sem incorrer em erros, realizar uma avaliação estatística sobre a equação de regressão. Acrescida a esta observação, a análise do gráfico dos resíduos na FIG. 8, a TABELA 6 - Análise de variância (ANOVA) para o ácido esteárico.

\begin{tabular}{|c|c|c|c|c|c|c|}
\hline Fonte de variação & GL & SQ & $\mathbf{M Q}$ & $\mathbf{F}_{\text {calc. }}$ & $F_{\text {tab. }}$ & $\mathbf{R}^{2}$ \\
\hline Regressão (R) & 5 & 509,545 & 101,909 & 8,02 & 3,97 & \multirow{5}{*}{$85,1 \%$} \\
\hline Resíduos (r) & 7 & 88,968 & 12,710 & & & \\
\hline Falta de ajuste (faj) & 3 & 80,661 & 26,887 & 12,95 & 6,59 & \\
\hline Erro puro (ep) & 4 & 8,307 & 2,077 & & & \\
\hline Total & 12 & 598,513 & & & & \\
\hline \multicolumn{7}{|c|}{ I.C. $=95 \%$} \\
\hline
\end{tabular}

$\mathrm{GL}$ = graus de liberdade; $\mathrm{SQ}$ : soma quadrática; $\mathrm{MQ}$ : média quadrática; $\mathrm{R}^{2}=$ coeficiente de determinação do modelo.

\% máxima de variação explicável: $\left[\left(S Q_{T}-S Q_{e p}\right) / S Q_{T}\right] \times 100$

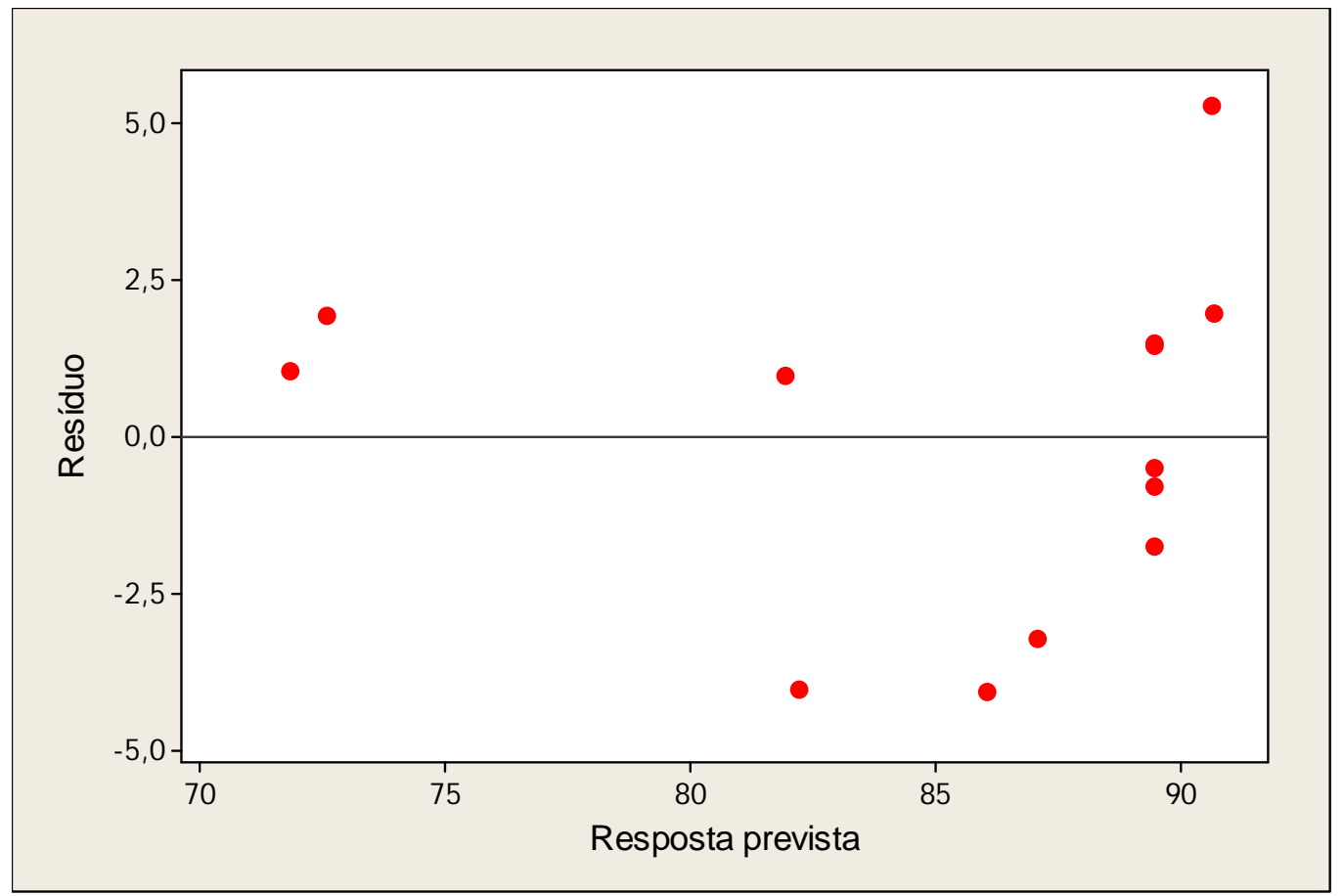

FIGURA 8 - Resíduos relativos ao modelo adotado para o ácido esteárico. A disposição dos pontos não possui uma aparência muito aleatória. 
despeito da pequena quantidade de pontos, mostra que estes não estão distribuídos de forma aleatória, sendo mais uma evidência da falta de ajuste do modelo, pelo menos sob o ponto de vista estatístico.

Uma vez que a diferença entre os valores de $F_{\text {calc. e }} F_{\text {tab. foi pequena, a }}$ qualidade do ajuste do modelo foi verificada no intervalo de confiança de $99 \%$. Na TAB. 7 é apresentada a análise de variância nessa condição. É importante notar

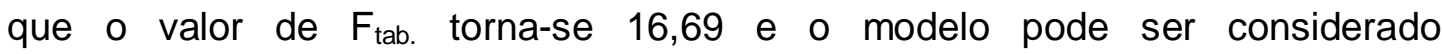
numericamente válido, permitindo verificar o grau de significância da equação de regressão. Além disso, se a complexidade do processo em estudo for elevada, aliada a um adequado conhecimento prévio do processo por parte dos pesquisadores, é tolerável aceitar uma pequena falta de ajuste do modelo, a qual não irá comprometer a discussão e análise dos resultados, permitindo caracterizar, em um determinado nível de confiança, a influência das variáveis investigadas sobre a resposta de interesse.

Como o modelo não apresentou falta de ajuste considerando o intervalo de confiança de $99 \%$, foi possível aplicar o teste $\mathrm{F}$ para validar o modelo de regressão. $O$ valor de $F_{\text {tab. }}(7,46)$ foi inferior ao valor de $F_{\text {calc. }}(8,02)$, indicando uma regressão levemente significativa. Apesar das condições ideais para realizar previsões a partir do modelo não terem sido amplamente satisfeitas, com um valor

TABELA 7 - Análise de variância (ANOVA) para o ácido esteárico (I.C. = 99\%).

\begin{tabular}{|c|c|c|c|c|c|c|}
\hline Fonte de variação & GL & SQ & $\mathbf{M Q}$ & $\mathbf{F}_{\text {calc. }}$ & $\mathbf{F}_{\text {tab. }}$ & $\mathbf{R}^{2}$ \\
\hline Regressão & 5 & 509,545 & 101,909 & 8,02 & 7,46 & \\
\hline Resíduos & 7 & 88,968 & 12,710 & & & \\
\hline Falta de ajuste (faj) & 3 & 80,661 & 26,887 & 12,95 & 16,69 & $85,1 \%$ \\
\hline Erro puro (ep) & 4 & 8,307 & 2,077 & & & \\
\hline Total & 12 & 598,513 & & & & \\
\hline \multicolumn{7}{|c|}{ I.C. $=99 \%$} \\
\hline \multicolumn{7}{|c|}{ \% máxima de variação explicável: 98,6\% } \\
\hline
\end{tabular}

$\mathrm{GL}$ = graus de liberdade; SQ: soma quadrática; $\mathrm{MQ}$ : média quadrática; $\mathrm{R}^{2}=$ coeficiente de determinação do modelo.

$\%$ máxima de variação explicável: $\left[\left(S Q_{T}-S Q_{e p}\right) / S Q_{T}\right] \times 100$ 


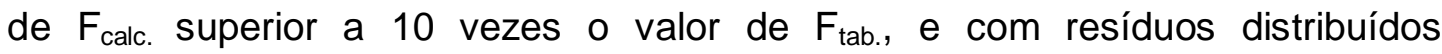
aleatoriamente em torno da média (Barros Neto et al., 2002), foi possível sugerir, com base no conhecimento do processo adquirido até o momento e com os dados representados na FIG. 7, o caminho para a otimização da resposta e estimar os termos que apresentaram influência significativa na densidade relativa das pastilhas de $\mathrm{NbAl}_{3}$.

\section{Estimativa da influência das variáveis sobre a resposta}

Uma análise mais atenta da FIG. 7 permite constatar que, para tempos de moagem igual e superior a 60 minutos, a adição de uma maior quantidade de ácido esteárico foi benéfica para 0 aumento da densidade relativa. Contrariamente, para menores tempos de moagem (inferiores a 60 minutos), houve uma diminuição na resposta com a adição de uma maior quantidade de agente. Neste planejamento, o maior valor (95,88\%) foi obtido com 30 minutos de moagem e 0,5\% de ACP, representando um acréscimo de aproximadamente $6,5 \%$ em relação à condição padrão (60 minutos de moagem e $1,0 \%$ de ACP). Um segundo resultado também considerado promissor $(92,62 \%)$ foi obtido com 60 minutos de moagem e $1,7 \%$ de ácido esteárico, representando um aumento de $3,2 \%$.

Com base nos resultados apresentados na TAB. 8, o emprego do modelo quadrático resultou na seguinte equação:

$$
\begin{aligned}
& \hat{y}_{\text {ác.est. }}=89,41-3,4158 x_{1}+1,6380 x_{2}-6,0159 x_{1}^{2}-0,5434 x_{2}^{2}+5,9700 x_{1} x_{2}(5.2) \\
& \begin{array}{lllll}
( \pm 0,644) \quad( \pm 0,510) & ( \pm 0,510) \quad( \pm 0,546) \quad( \pm 0,546) \quad( \pm 0,720)
\end{array}
\end{aligned}
$$

Observa-se que somente os termos linear e quadrático relacionados à quantidade de ACP $\left(\mathrm{x}_{2}\right.$ e $\left.\mathrm{x}_{2}{ }^{2}\right)$ não são significativos, ao passo que todos os outros parâmetros, em especial o termo quadrático relacionado ao tempo de moagem $\left(\mathrm{x}_{1}{ }^{2}\right)$ e a interação entre esta variável e a quantidade de ACP $\left(\mathrm{x}_{1} \mathrm{x}_{2}\right)$, apresentaram efeitos pronunciados sobre a resposta avaliada no nível de confiança considerado (99\%). Os termos quadráticos e a interação entre as variáveis fornecem uma medida da curvatura da superfície na região investigada. Geometricamente, a elevada significância desses efeitos indica que a região estudada não é planar e contém um ponto de máximo. Deste modo, o local de interesse (que contém a 
condição para se obter o maior valor de densidade relativa) encontra-se próximo ou dentro do intervalo dos experimentos realizados.

Nas FIG. 9 e 10 são apresentadas, respectivamente, a superfície de resposta e as curvas de nível para a região investigada para o ácido esteárico. A pronunciada curvatura observada na FIG. 9 é mais um indício de que uma condição ótima para a densidade relativa do $\mathrm{NbAl}_{3}$ pode ser encontrada dentro do intervalo estudado. No entanto, em razão do valor de $F_{\text {calc }}$ estar próximo do valor de $F_{\text {tab }}$ e da falta de aleatoriedade na distribuição dos resíduos (FIG. 8), os termos da equação 5.2 devem ser analisados com cautela, uma vez que a falta de ajuste do modelo não é totalmente desprezível.

TABELA 8 - Estimativa do grau de significância das variáveis para o ácido esteárico.

\begin{tabular}{|c|c|c|c|c|c|}
\hline Variáveis & Efeitos & b & $\mathbf{s}_{\mathbf{b}}$ & $t_{4} \times s_{b}$ & I.C. \\
\hline $\begin{array}{c}\mathrm{b}_{0} \\
\text { (grande média) }\end{array}$ & - & 89,41 & 0,644 & 2,965 & $(86,4450 ; 92,3750)$ \\
\hline $\begin{array}{c}\mathrm{X}_{1} \\
\text { (tempo de moagem) }\end{array}$ & $-6,8316$ & $-3,4158$ & 0,510 & 2,348 & $(-5,7638 ;-1,0678)$ \\
\hline $\begin{array}{c}\mathrm{X}_{2} \\
\text { (quantidade de ACP) }\end{array}$ & 3,276 & 1,6380 & 0,510 & 2,348 & $(-0,7100 ; 3,9860)$ \\
\hline $\begin{array}{c}\mathrm{X}_{1}{ }^{2} \\
(\text { tempo de moagem })^{2}\end{array}$ & - & $-6,0159$ & 0,546 & 2,514 & $(-8,5299 ;-3,5019)$ \\
\hline $\begin{array}{c}\mathrm{x}_{2}{ }^{2} \\
(\text { quantidade de } \mathrm{ACP})^{2}\end{array}$ & - & $-0,5434$ & 0,546 & 2,514 & $(-3,0574 ; 1,9706)$ \\
\hline $\begin{array}{c}\mathrm{X}_{1} \mathrm{X}_{2} \\
\text { (tempo de moagem } \times \\
\text { quantidade de } \mathrm{ACP} \text { ) }\end{array}$ & 11,940 & 5,9700 & 0,720 & 3,315 & $(2,6550 ; 9,2850)$ \\
\hline \multicolumn{3}{|c|}{$s=1,4411$} & \multicolumn{3}{|c|}{$\mathrm{t}_{4}=4,604$ a $99 \%$ de confiança } \\
\hline
\end{tabular}

$\mathrm{b}=$ coeficientes do modelo; $\mathrm{s}_{\mathrm{b}}=$ erro padrão dos coeficientes do modelo;

$\mathrm{s}=$ erro experimental; $\mathrm{t}_{4}=$ distribuição de Student com quatro graus de liberdade; I.C. = intervalo de confiança. 


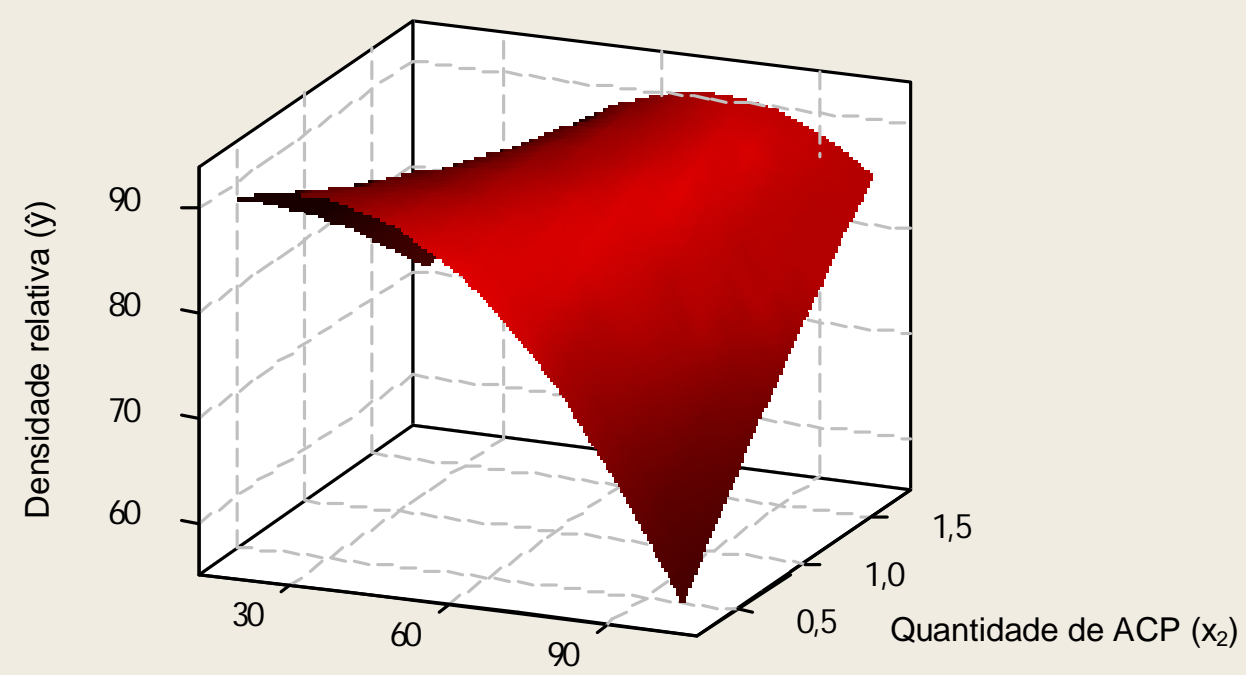

Tempo de moagem $\left(x_{1}\right)$

FIGURA 9 - Superfície de resposta descrita pela equação 5.2.

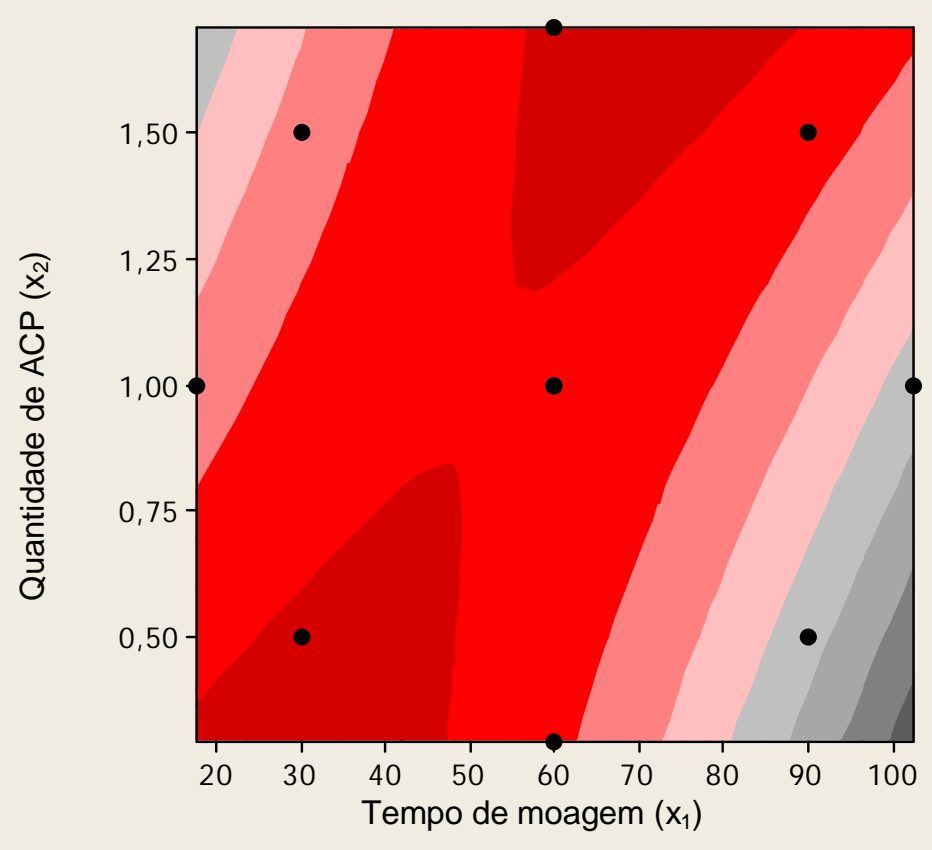

FIGURA 10 - Curvas de nível para a equação 5.2. 


\subsubsection{Planejamento composto central para o etanol}

Os resultados de densidade relativa para $0 \mathrm{NbAl}_{3}$ encontrados no planejamento de experimentos para o etanol podem ser visualizados na TAB. 9 e na FIG. 11.

Os cálculos matemáticos utilizados para avaliar a qualidade do ajuste do modelo estão apresentados na TAB. 10.

TABELA 9 - Resultados do planejamento composto central para o etanol. Os níveis das variáveis estão codificados.

\begin{tabular}{|c|c|c|c|c|c|}
\hline Planejamento & $\begin{array}{c}\text { Ordem } \\
\text { padrão }\end{array}$ & $\begin{array}{c}\text { Ordem dos } \\
\text { ensaios } \\
\text { realizados }\end{array}$ & $\begin{array}{c}\text { Tempo de } \\
\text { moagem } \\
\left(x_{1}\right)\end{array}$ & $\begin{array}{c}\text { Quantidade } \\
\text { de ACP } \\
\left(x_{2}\right)\end{array}$ & $\begin{array}{l}\text { Densidade } \\
\text { relativa } \\
\left(\% d_{t}\right)^{*}\end{array}$ \\
\hline \multirow{4}{*}{$\begin{array}{l}\text { Pontos } \\
\text { fatoriais }\end{array}$} & 1 & 5 & -1 & -1 & 96,05 \\
\hline & 2 & 6 & +1 & -1 & 72,94 \\
\hline & 3 & 3 & -1 & +1 & 77,68 \\
\hline & 4 & 11 & +1 & +1 & 84,29 \\
\hline \multirow{4}{*}{ Pontos axiais } & 5 & 9 & $-\sqrt{2}$ & 0 & 69,76 \\
\hline & 6 & 8 & 0 & $\sqrt{2}$ & 86,43 \\
\hline & 7 & 7 & $\sqrt{ } 2$ & 0 & 76,45 \\
\hline & 8 & 10 & 0 & $-\sqrt{2}$ & 83,97 \\
\hline \multirow{5}{*}{$\begin{array}{l}\text { Pontos } \\
\text { centrais }\end{array}$} & 9 & 1 & 0 & 0 & 91,41 \\
\hline & 10 & 4 & 0 & 0 & 92,62 \\
\hline & 11 & 13 & 0 & 0 & 92,14 \\
\hline & 12 & 2 & 0 & 0 & 93,77 \\
\hline & 13 & 12 & 0 & 0 & 91,16 \\
\hline
\end{tabular}

\footnotetext{
${ }^{*} \mathrm{~d}_{\mathrm{t}}=4,54 \mathrm{~g} / \mathrm{cm}^{3}$ (densidade teórica do $\mathrm{NbAl}_{3}$ ).
} 


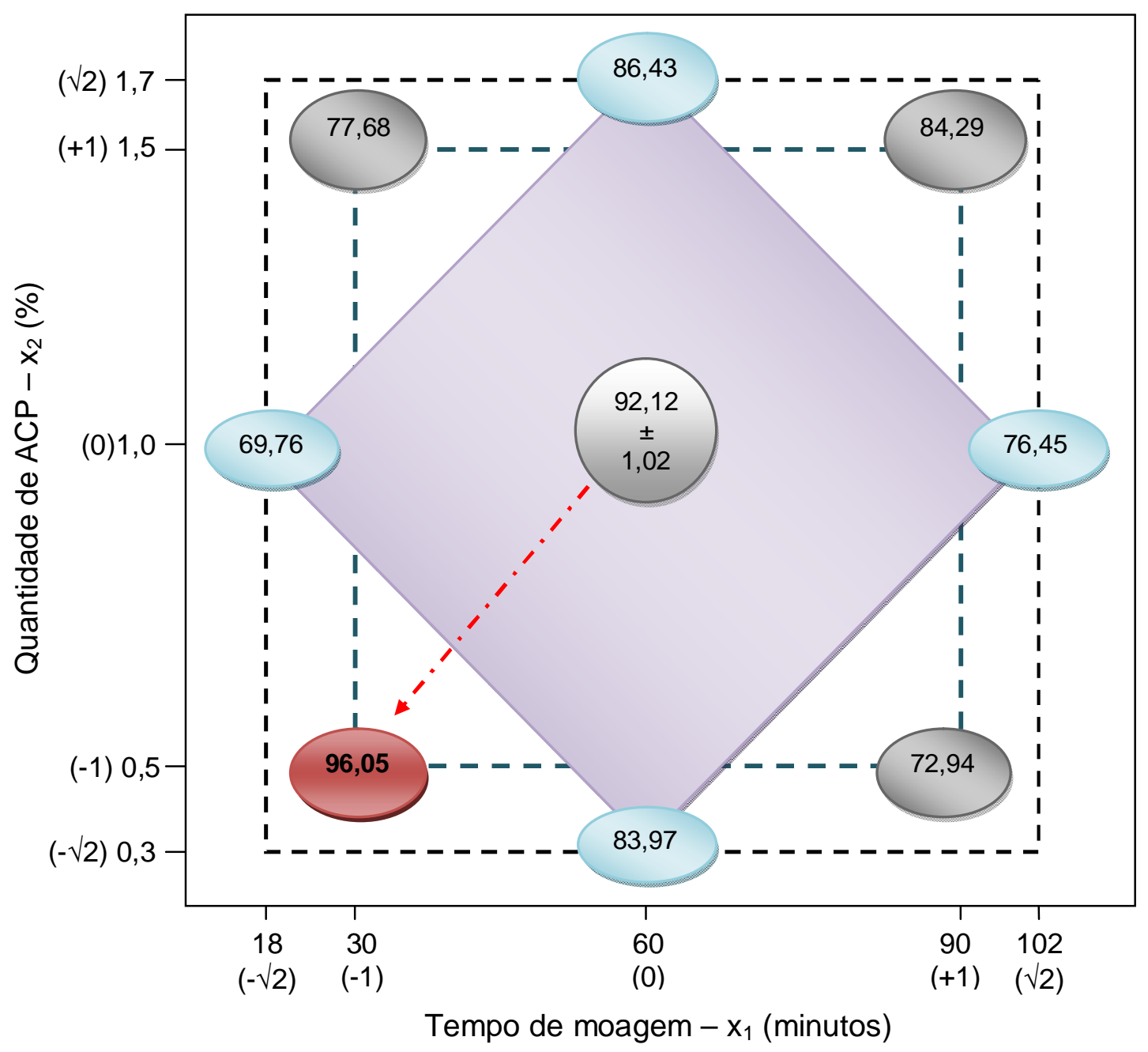

FIGURA 11 - Representação geométrica dos resultados obtidos no planejamento composto central para o etanol. A seta vermelha indica a direção para a otimização da resposta.

\section{Avaliação da qualidade do ajuste do modelo}

Na TAB. 10 é apresentada a análise de variância para verificar a qualidade do ajuste do modelo adotado para o etanol. A porcentagem de variação explicada pelo modelo $\left(R^{2}\right)$ foi de $85,6 \%$. A aplicação do teste $F$ revelou um valor estatisticamente significativo para a falta de ajuste, uma vez que o valor de $F_{\text {calc. }}$ $(39,77)$ foi muito superior ao valor de $F_{\text {tab. }}(6,59)$. Nesse caso, a falta de ajuste detectada foi superior à encontrada para o ácido esteárico $(12,95)$ e é significativa mesmo no nível de confiança de $99 \%\left(F_{\text {tab. }}=16,69\right)$. A distribuição dos resíduos também não é aleatória, conforme mostrado na FIG. 12. Embora tal constatação 
não seja tão patente quanto à verificada para o ácido esteárico, representa mais uma evidência de que o modelo adotado não é adequado para realizar previsões.

TABELA 10 - Análise de variância (ANOVA) para o etanol.

\begin{tabular}{|c|c|c|c|c|c|c|}
\hline Fonte de variação & GL & SQ & $\mathbf{M Q}$ & $\mathbf{F}_{\text {calc. }}$ & $\mathbf{F}_{\text {tab. }}$ & $\mathbf{R}^{2}$ \\
\hline Regressão & 5 & 758,756 & 151,751 & 8,30 & 3,97 & \multirow{5}{*}{$85,6 \%$} \\
\hline Resíduos & 7 & 127,015 & 18,274 & & & \\
\hline Falta de ajuste (faj) & 3 & 123,766 & 41,255 & 39,77 & 6,59 & \\
\hline Erro puro (ep) & 4 & 4,149 & 1,037 & & & \\
\hline Total & 12 & 886,671 & & & & \\
\hline \multicolumn{7}{|c|}{ I.C. $=95 \%$} \\
\hline
\end{tabular}

$\mathrm{GL}=$ graus de liberdade; $\mathrm{SQ}$ : soma quadrática; $\mathrm{MQ}$ : média quadrática;

$\mathrm{R}^{2}=$ coeficiente de determinação do modelo.

\% máxima de variação explicável: $\left[\left(S Q_{T}-S Q_{e p}\right) / S Q_{T}\right] \times 100$

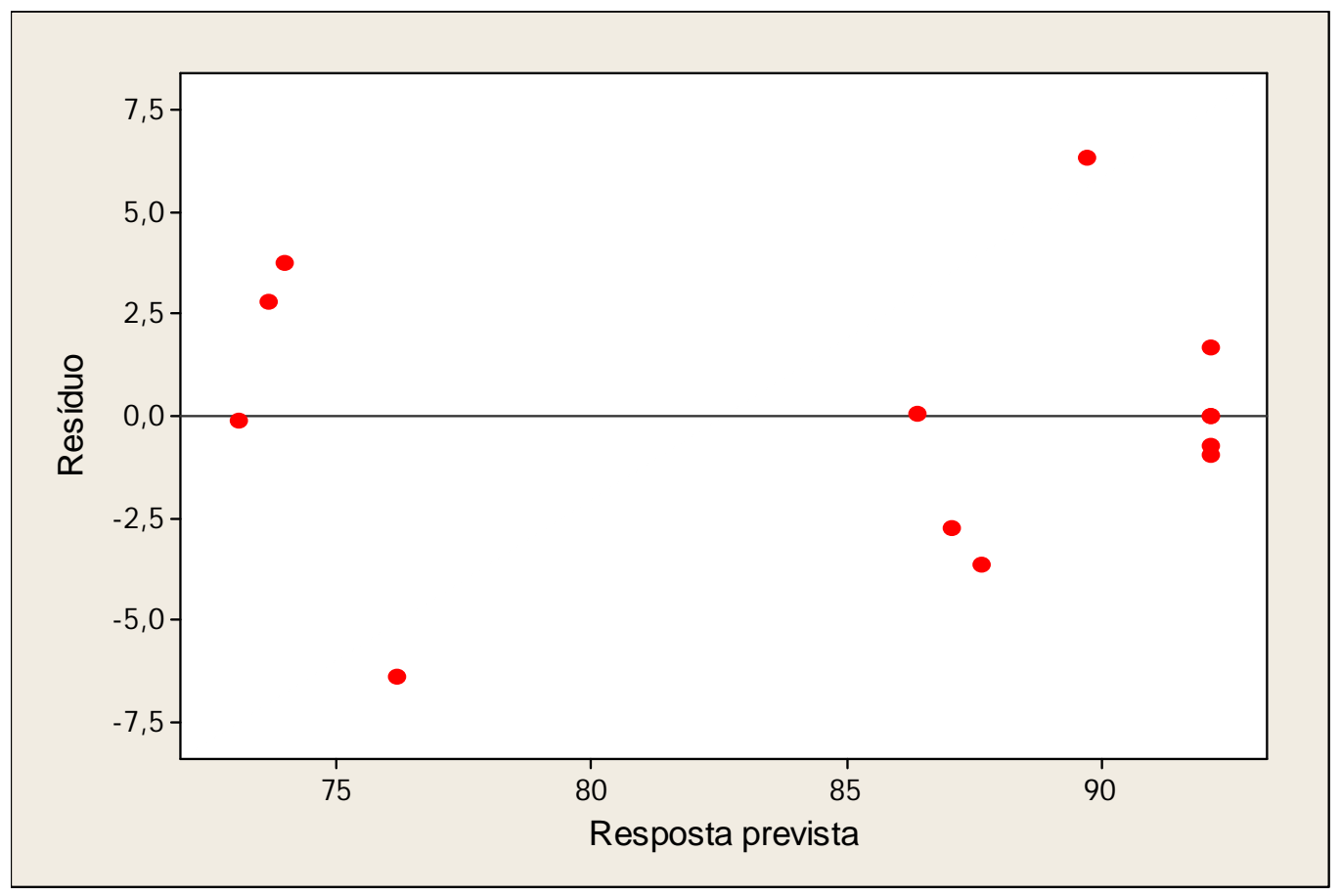

FIGURA 12 - Resíduos relativos ao modelo adotado para o etanol. É possível observar certo padrão na distribuição dos resíduos. 
Apesar do considerável valor encontrado para a falta de ajuste, a análise dos dados da FIG. 11 permite tentar inferir algumas considerações a cerca do modelo, bem como sugerir a localização da região mais provável para obter maiores valores de densidade relativa para as pastilhas de $\mathrm{NbAl}_{3}$.

\section{Estimativa da influência das variáveis sobre a resposta}

A observação da FIG. 11 permite constatar que, para tempos de moagem superiores a 60 minutos, a adição de uma maior quantidade de etanol, a exemplo do ácido esteárico, revelou-se favorável para aumentar a densidade relativa das pastilhas reagidas. Nas condições com menores tempos de moagem (inferiores a 60 minutos), o emprego de uma maior quantidade de agente foi prejudicial às densidades, em especial para 18 minutos de moagem com 1,0\% de ACP. Neste planejamento, o maior valor $(96,05 \%)$ também foi obtido para 30 minutos de moagem com $0,5 \%$ de ACP. Entretanto, o acréscimo em relação à condição padrão (aproximadamente 4,0\%) não foi tão pronunciado quanto o verificado para o ácido esteárico (6,5\%), uma vez que o etanol mostrou-se mais efetivo que o ácido para promover a melhoria na densidade da pastilha obtida com 60 minutos de moagem com $1,0 \%$ de agente.

A expressão do modelo quadrático para o etanol pode ser visualizada na equação a seguir.

$$
\hat{y}_{\text {et. }}=\underset{( \pm 0,455)}{92,12-0,8799 x_{1}-0,4426 x_{2}-8,6086 x_{1}^{2}-2,5611 x_{2}^{2}+7,4300 x_{1} x_{2}}
$$

Os valores dos termos apresentados na equação 5.3 não devem ser considerados como absolutos, uma vez que a falta de ajuste verificada para o modelo foi significativa. Por este motivo, os cálculos para a estimativa do grau de significância não foram apresentados. Tais valores podem apenas indicar as variáveis que apresentaram uma influência mais pronunciada sobre a densidade, bem como para estimar a aparência geométrica da curvatura da superfície de resposta. Segundo o modelo adotado, somente os termos quadráticos relacionados ao tempo de moagem $\left(\mathrm{x}_{1}{ }^{2}\right)$ e à quantidade de $\operatorname{ACP}\left(\mathrm{x}_{2}{ }^{2}\right)$, bem como a interação entre estas variáveis $\left(x_{1} x_{2}\right)$ foram considerados significativos no nível de confiança de $95 \%$. Uma tentativa para interpretar estes resultados deve ser 
feita com muita cautela, em razão da forte interação entre as variáveis e da contribuição negativa dos termos quadráticos. A interação positiva entre as variáveis indica que uma diminuição no tempo de moagem deve ser acompanhada de uma também redução na quantidade de etanol e vice-versa. Entretanto, deve-se tomar cuidado com os deslocamentos em virtude do alto grau de significância dos termos quadráticos do modelo.

\subsubsection{Planejamento composto central para o metanol}

As respostas obtidas para o planejamento de experimentos para o metanol estão apresentadas na TAB. 11 e na FIG. 13.

Nas TAB. 12 e 13 podem ser visualizados os resultados dos cálculos estatísticos utilizados na construção e avaliação do modelo quadrático para o metanol.

\section{Avaliacão da qualidade do ajuste do modelo}

A validade do modelo adotado para o metanol foi avaliada mediante a análise de variância (ANOVA) apresentada na TAB. 12, e por meio da observação do gráfico dos resíduos na FIG. 14. Neste modelo, o coeficiente de determinação $\left(R^{2}\right)$ foi de $97,7 \%$, indicando que a maior parte da variação total das observações em torno da média pode ser descrita pela equação de regressão, uma vez que a aplicação do teste $\mathrm{F}$, no nível de confiança de $95 \%$, revelou um modelo bem

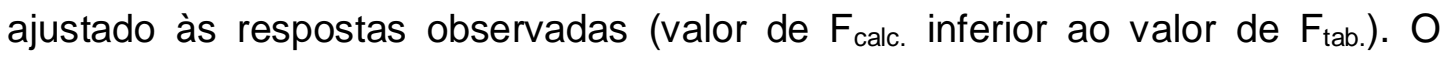
resultado de $F_{\text {calc. }}$ para a equação de regressão foi altamente significativo, sendo aproximadamente 15 vezes maior do que o valor de $F_{\text {tab. }} O$ gráfico dos resíduos (FIG. 14) também se mostrou satisfatório, com pontos distribuídos de forma aleatória, embora indiquem uma certa heteroscedasticidade (a variância dos erros não é constante ao longo de toda a faixa estudada). 
TABELA 11 - Resultados do planejamento composto central para o metanol. Os níveis das variáveis estão codificados.

\begin{tabular}{|c|c|c|c|c|c|}
\hline Planejamento & $\begin{array}{l}\text { Ordem } \\
\text { padrão }\end{array}$ & $\begin{array}{c}\text { Ordem dos } \\
\text { ensaios } \\
\text { realizados }\end{array}$ & $\begin{array}{c}\text { Tempo de } \\
\text { moagem } \\
\left(x_{1}\right)\end{array}$ & $\begin{array}{c}\text { Quantidade } \\
\text { de ACP } \\
\left(x_{2}\right)\end{array}$ & $\begin{array}{c}\text { Densidade } \\
\text { relativa } \\
\left(\% d_{t}\right)^{*}\end{array}$ \\
\hline \multirow{4}{*}{$\begin{array}{l}\text { Pontos } \\
\text { fatoriais }\end{array}$} & 1 & 9 & -1 & -1 & 87,24 \\
\hline & 2 & 6 & +1 & -1 & 74,83 \\
\hline & 3 & 3 & -1 & +1 & 94,88 \\
\hline & 4 & 7 & +1 & +1 & 85,04 \\
\hline \multirow{4}{*}{ Pontos axiais } & 5 & 8 & $-\sqrt{ } 2$ & 0 & 92,00 \\
\hline & 6 & 11 & 0 & $\sqrt{2}$ & 89,00 \\
\hline & 7 & 4 & $\sqrt{2}$ & 0 & 77,06 \\
\hline & 8 & 10 & 0 & $-\sqrt{ } 2$ & 78,27 \\
\hline \multirow{5}{*}{$\begin{array}{l}\text { Pontos } \\
\text { centrais }\end{array}$} & 9 & 13 & 0 & 0 & 88,79 \\
\hline & 10 & 1 & 0 & 0 & 90,33 \\
\hline & 11 & 2 & 0 & 0 & 87,64 \\
\hline & 12 & 5 & 0 & 0 & 89,50 \\
\hline & 13 & 12 & 0 & 0 & 88,00 \\
\hline
\end{tabular}

${ }^{*} \mathrm{~d}_{\mathrm{t}}=4,54 \mathrm{~g} / \mathrm{cm}^{3}$ (densidade teórica do $\mathrm{NbAl}_{3}$ ). 


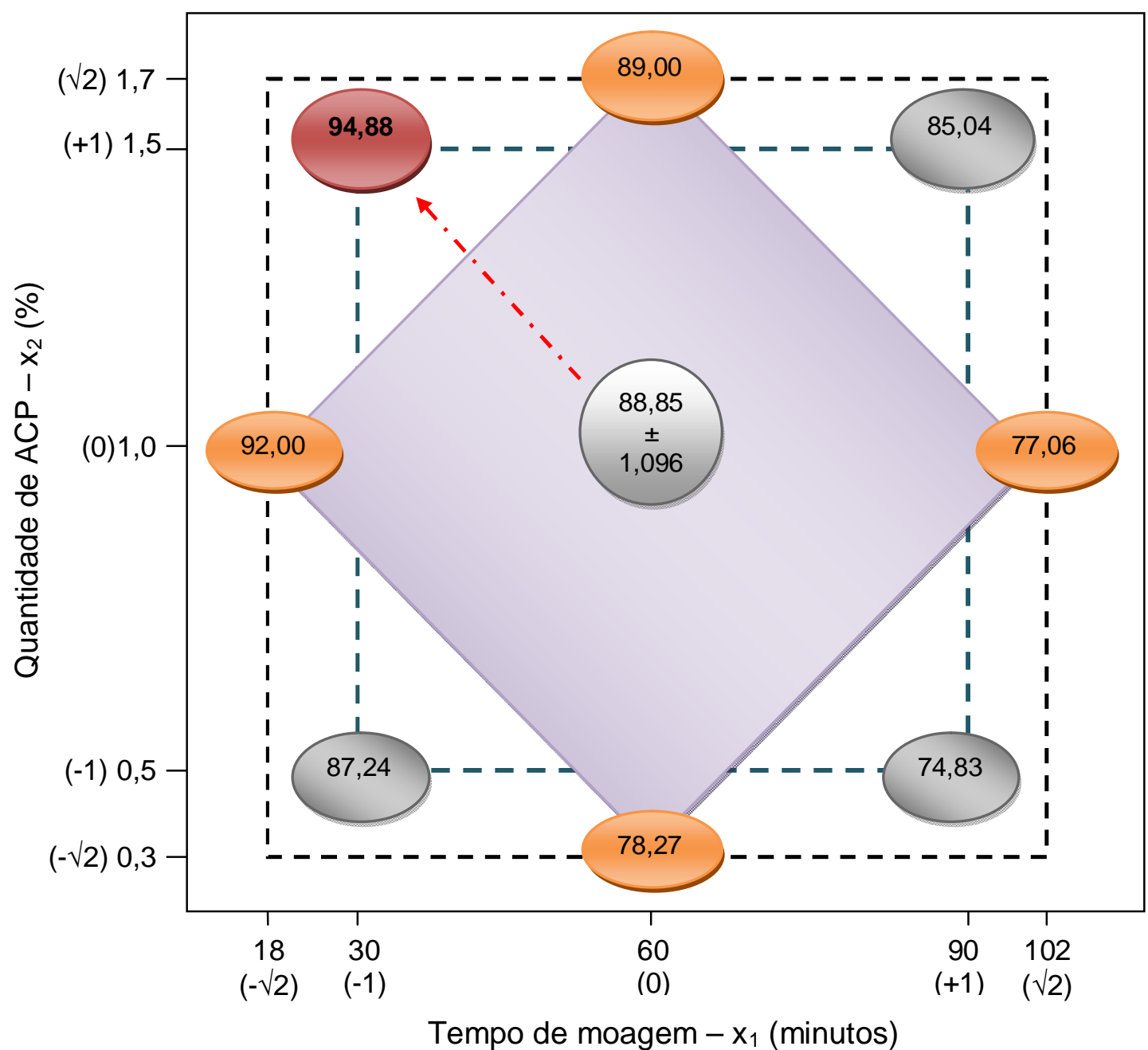

FIGURA 13 - Representação geométrica dos resultados obtidos no planejamento composto central para o metanol. A seta vermelha indica a direção para a otimização da resposta.

TABELA 12 - Análise de variância (ANOVA) para o metanol.

\begin{tabular}{|c|c|c|c|c|c|c|}
\hline Fonte de variação & GL & SQ & MQ & $\mathbf{F}_{\text {calc. }}$ & $F_{\text {tab. }}$ & $\mathbf{R}^{2}$ \\
\hline Regressão & 5 & 424,758 & 84,952 & 60,31 & 3,97 & \multirow{5}{*}{$97,7 \%$} \\
\hline Resíduos & 7 & 9,860 & 1,409 & & & \\
\hline Falta de ajuste (faj) & 3 & 5,056 & 1,685 & 1,40 & 6,59 & \\
\hline Erro puro (ep) & 4 & 4,803 & 1,201 & & & \\
\hline Total & 12 & 434,618 & & & & \\
\hline \multicolumn{7}{|c|}{ I.C. $=95 \%$} \\
\hline \multicolumn{7}{|c|}{ \% máxima de variação explicável: 98,9\% } \\
\hline
\end{tabular}

$\mathrm{GL}$ = graus de liberdade; SQ: soma quadrática; $\mathrm{MQ}$ : média quadrática; $\mathrm{R}^{2}=$ coeficiente de determinação do modelo.

\% máxima de variação explicável: $\left[\left(S Q_{T}-S Q_{e p}\right) / S Q_{T}\right]$ x 100 


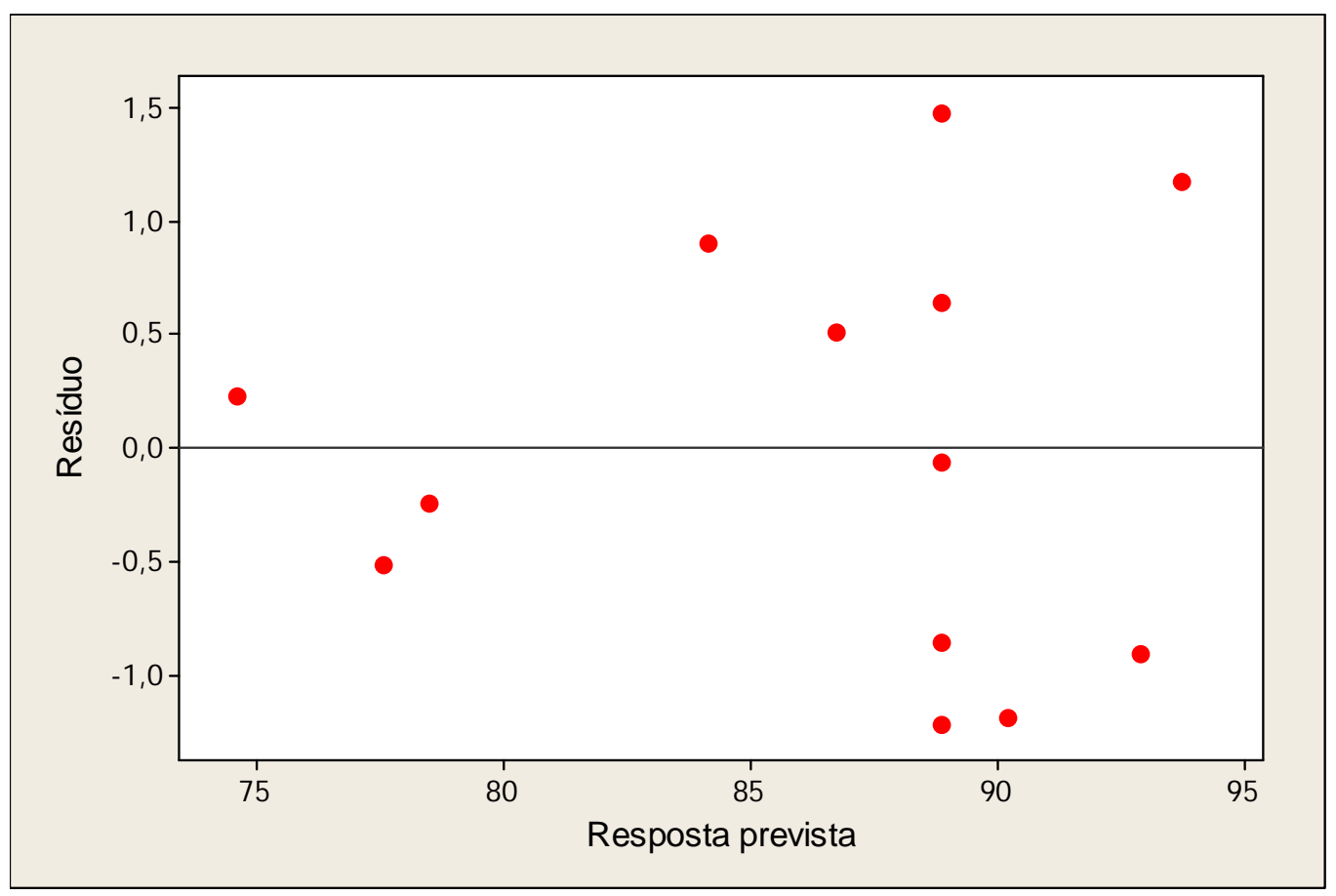

FIGURA 14 - Resíduos relativos ao modelo adotado para o metanol.

Como as condições para validar o modelo foram amplamente satisfeitas, com o grau de significância estatística para a equação de regressão superior a 10

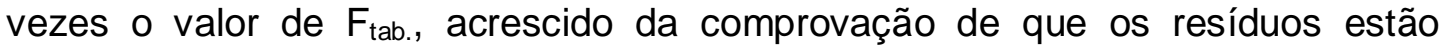
distribuídos aleatoriamente em torno da média (pelo exame do gráfico dos

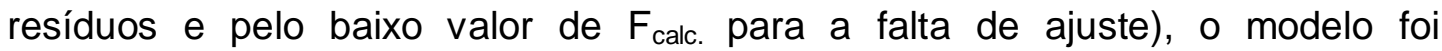
considerado útil para fins de previsão e para descrever a superfície de resposta na região investigada.

\section{Estimativa da influência das variáveis sobre a resposta}

Os resultados apresentados graficamente na FIG. 13 indicam que, para um mesmo tempo de moagem, maiores densidades relativas podem ser obtidas com a adição de uma maior quantidade de metanol. Tal como observado para o ácido esteárico e etanol, o emprego de 30 minutos de moagem gerou o maior valor de densidade $(94,88 \%)$. No entanto, para o metanol este objetivo foi atingido com $1,5 \%$ do agente, ao contrário do ácido esteárico e etanol, cujas maiores densidades foram obtidas com adições de 0,5\% desses ACPs. Em relação à condição padrão, houve uma melhoria de 6,0\% na densidade relativa do $\mathrm{NbAl}_{3}$. Um segundo resultado satisfatório (em termos de densidade) foi obtido para 18 
minutos de moagem com 1,0\% do agente, representando um acréscimo de 3,2\% em relação à condição padrão.

A expressão para o modelo quadrático adotado, com seus respectivos erros padrão, pode ser visualizada na equação 5.4 .

$$
\hat{y}_{\text {met. }}=\underset{( \pm 0,531)}{88,85-5,4223 x_{1}}+\underset{( \pm 0,420)}{8,1281} \quad( \pm 0,420) \quad \underset{( \pm 0,450)}{1,8073 x_{1}{ }^{2}-2,2548 x_{2}^{2}}+\underset{( \pm 0,450)}{0,6425 x_{1} x_{2}}(5.4)
$$

Como não houve evidência de falta de ajuste do modelo, os erros padrão dos parâmetros foram obtidos a partir dos resíduos da equação de regressão, calculados com sete graus de liberdade.

\begin{tabular}{|c|c|c|c|c|c|}
\hline Variáveis & Efeitos & b & $\mathbf{S}_{\mathbf{b}}$ & $t_{7} \times s_{b}$ & I.C. \\
\hline $\begin{array}{c}\mathrm{b}_{0} \\
\text { (grande média) }\end{array}$ & - & 88,85 & 0,531 & 1,256 & $(87,594 ; 90,106)$ \\
\hline $\begin{array}{c}\mathrm{x}_{1} \\
\text { (tempo de moagem) }\end{array}$ & $-10,8446$ & $-5,4223$ & 0,420 & 0,993 & $(-6,4153 ;-4,4293)$ \\
\hline $\begin{array}{c}\mathrm{X}_{2} \\
\text { (quantidade de ACP) }\end{array}$ & 8,2562 & 4,1281 & 0,420 & 0,993 & $(3,1351 ; 5,1211)$ \\
\hline $\begin{array}{c}\mathrm{x}_{1}{ }^{2} \\
(\text { tempo de moagem })^{2}\end{array}$ & - & $-1,8073$ & 0,450 & 1,064 & $(-2,8713 ;-0,7433)$ \\
\hline $\begin{array}{c}\mathrm{x}_{2}{ }^{2} \\
\text { (quantidade de } \mathrm{ACP})^{2}\end{array}$ & - & $-2,2548$ & 0,450 & 1,064 & $(-3,3188 ;-1,1908)$ \\
\hline $\begin{array}{c}\mathrm{X}_{1} \mathrm{X}_{2} \\
\text { (tempo de moagem } \times \\
\text { quantidade de } \mathrm{ACP} \text { ) }\end{array}$ & 1,2850 & 0,6425 & 0,593 & 1,402 & $(-0,7595 ; 2,0445)$ \\
\hline \multicolumn{3}{|c|}{$s=1,187$} & \multicolumn{3}{|c|}{$t_{7}=2,365$ a $95 \%$ de confiança } \\
\hline
\end{tabular}

TABELA 13 - Estimativa do grau de significância das variáveis para o metanol.

$\mathrm{b}=$ coeficientes do modelo; $\mathrm{s}_{\mathrm{b}}=$ erro padrão dos coeficientes do modelo;

$\mathrm{s}=$ erro experimental; $\mathrm{t}_{7}=$ distribuição de Student com sete graus de liberdade;

I.C. = intervalo de confiança. 
Pela equação do modelo e com os resultados apresentados na TAB. 13, pode-se observar que todos os termos, com exceção da interação entre as variáveis, foram considerados significativos no intervalo de confiança de $95 \%$. termo linear positivo para a quantidade de agente indica que pastilhas mais densas podem ser obtidas com a adição de uma maior porcentagem de metanol, ao passo que o sinal negativo para o tempo de moagem sugere que a diminuição no nível desta variável deve resultar em maiores valores para a resposta estudada. Entretanto, a contribuição negativa dos termos quadráticos indica que a região ótima deve estar próxima dos experimentos realizados.

Nas FIG. 15 e 16 estão representadas, respectivamente, a superfície de resposta e as curvas de nível para a região investigada para o metanol. Em termos geométricos, a superfície de resposta descrita para o modelo assemelhase a uma cumeeira. A região investigada apresenta um ponto de máximo localizado próximo de 18 minutos de moagem e 1,4\% de metanol. Nessa condição a estimativa para a densidade relativa é de aproximadamente 95\%, representando uma melhoria de quase $10 \%$ em relação ao ponto de origem (condição padrão).

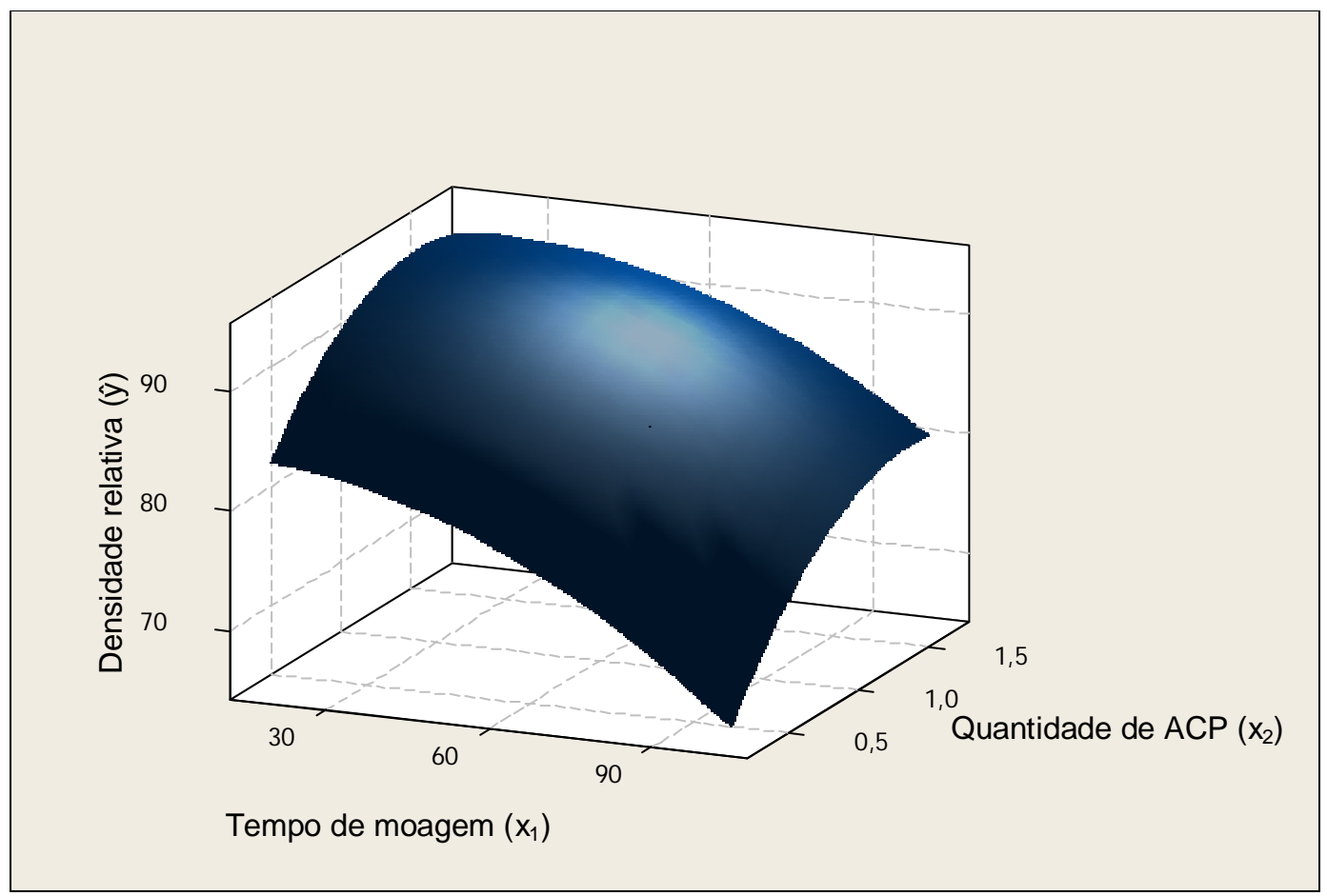

FIGURA 15 - Superfície de resposta descrita pela equação 5.4. 

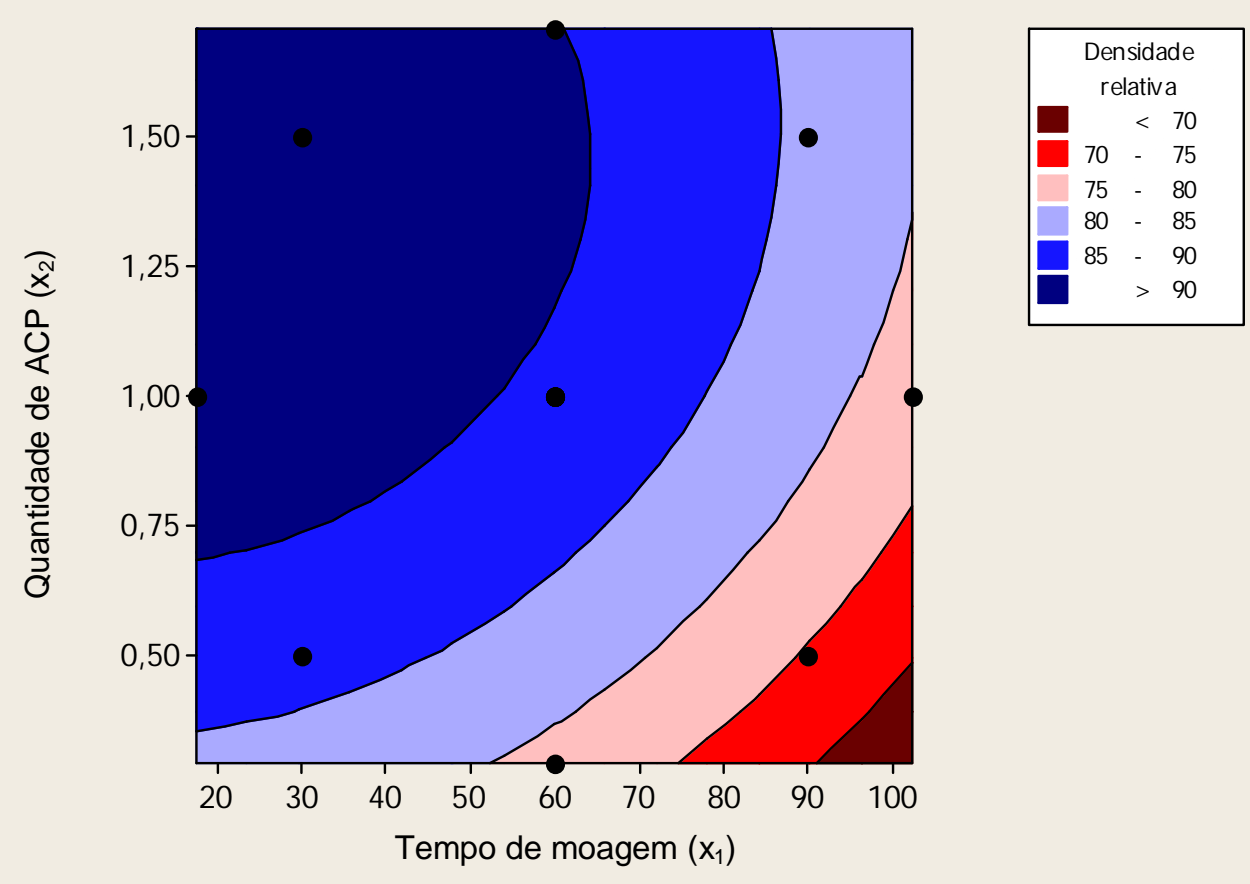

FIGURA 16 - Curvas de nível para a equação 5.4 .

\subsubsection{Planejamento composto central para o ciclohexano}

Os resultados do planejamento de experimentos para o ciclohexano podem ser visualizados na TAB. 14 e FIG. 17.

\section{Avaliação da qualidade do ajuste do modelo}

A análise de variância (ANOVA) apresentada na TAB. 15 mostra os resultados obtidos nos cálculos para avaliar o ajuste do modelo às respostas observadas. A equação de regressão adotada para o ciclohexano é capaz de explicar $98,6 \%\left(R^{2}\right)$ da variação total das observações em torno da média. $O$ modelo adotado não apresenta falta de ajuste, uma vez que o valor de $F_{\text {calc. foi }}$ menor do que o valor de $F_{\text {tab. }}$. A aplicação do teste $F$ para a regressão revelou

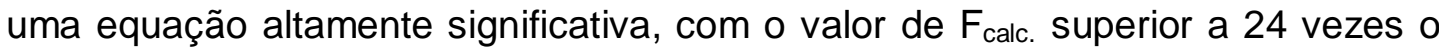

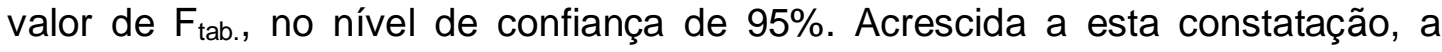
distribuição aleatória dos resíduos (FIG. 18) é mais um indicativo de que o modelo adotado está bem ajustado às observações e pode ser considerado útil para realizar previsões. 
TABELA 14 - Resultados do planejamento composto central para o ciclohexano. Os níveis das variáveis estão codificados.

\begin{tabular}{|c|c|c|c|c|c|}
\hline Planejamento & $\begin{array}{l}\text { Ordem } \\
\text { padrão }\end{array}$ & $\begin{array}{c}\text { Ordem dos } \\
\text { ensaios } \\
\text { realizados }\end{array}$ & $\begin{array}{c}\text { Tempo de } \\
\text { moagem } \\
\left(x_{1}\right)\end{array}$ & $\begin{array}{c}\text { Quantidade } \\
\text { de ACP } \\
\left(x_{2}\right)\end{array}$ & $\begin{array}{c}\text { Densidade } \\
\text { relativa } \\
\left(\% d_{t}\right)^{*}\end{array}$ \\
\hline \multirow{4}{*}{$\begin{array}{l}\text { Pontos } \\
\text { fatoriais }\end{array}$} & 1 & 1 & -1 & -1 & 82,70 \\
\hline & 2 & 9 & +1 & -1 & 71,22 \\
\hline & 3 & 12 & -1 & +1 & 90,96 \\
\hline & 4 & 5 & +1 & +1 & 72,94 \\
\hline \multirow{4}{*}{ Pontos axiais } & 5 & 4 & $-\sqrt{2}$ & 0 & 91,18 \\
\hline & 6 & 10 & 0 & $\sqrt{2}$ & 84,01 \\
\hline & 7 & 6 & $\sqrt{ } 2$ & 0 & 71,57 \\
\hline & 8 & 7 & 0 & $-\sqrt{ } 2$ & 76,13 \\
\hline \multirow{5}{*}{$\begin{array}{l}\text { Pontos } \\
\text { centrais }\end{array}$} & 9 & 3 & 0 & 0 & 76,70 \\
\hline & 10 & 13 & 0 & 0 & 78,23 \\
\hline & 11 & 2 & 0 & 0 & 77,53 \\
\hline & 12 & 8 & 0 & 0 & 78,09 \\
\hline & 13 & 11 & 0 & 0 & 76,17 \\
\hline
\end{tabular}

${ }^{*} \mathrm{~d}_{\mathrm{t}}=4,54 \mathrm{~g} / \mathrm{cm}^{3}$ (densidade teórica do $\mathrm{NbAl}_{3}$ ). 


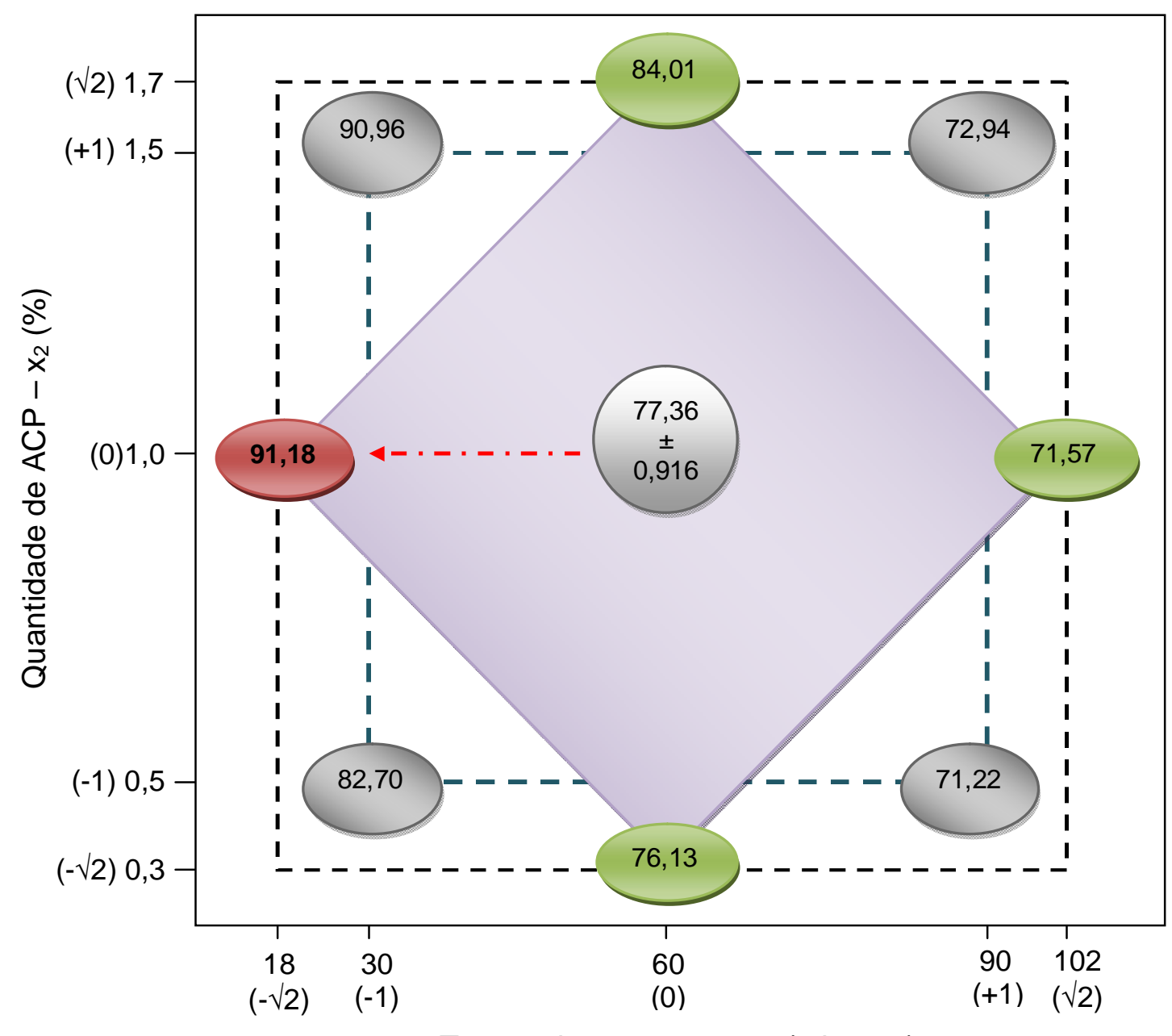

Tempo de moagem $-x_{1}$ (minutos)

FIGURA 17 - Representação geométrica dos resultados obtidos no planejamento composto central para o ciclohexano. A seta vermelha indica a direção para a otimização da resposta.

TABELA 15 - Análise de variância (ANOVA) para o ciclohexano.

\begin{tabular}{|c|c|c|c|c|c|c|}
\hline Fonte de variação & GL & SQ & MQ & $\mathbf{F}_{\text {calc. }}$ & $\mathbf{F}_{\text {tab. }}$ & $\mathbf{R}^{2}$ \\
\hline Regressão & 5 & 500,466 & 100,093 & 98,31 & 3,97 & \\
\hline Resíduos & 7 & 7,127 & 1,018 & & & \\
\hline Falta de ajuste (faj) & 3 & 3,773 & 1,258 & 1,50 & 6,59 & $98,6 \%$ \\
\hline Erro puro (ep) & 4 & 3,354 & 0,839 & & & \\
\hline Total & 12 & 507,593 & & & & \\
\hline \multicolumn{7}{|c|}{ I.C. $=95 \%$} \\
\hline & 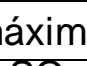 & variaç & xplicá & $9,3 \%$ & & \\
\hline
\end{tabular}

$\mathrm{GL}$ = graus de liberdade; SQ: soma quadrática; $\mathrm{MQ}$ : média quadrática;

$\mathrm{R}^{2}=$ coeficiente de determinação do modelo.

$\%$ máxima de variação explicável: $\left[\left(S Q_{T}-S Q_{e p}\right) / S Q_{T}\right]$ x 100 


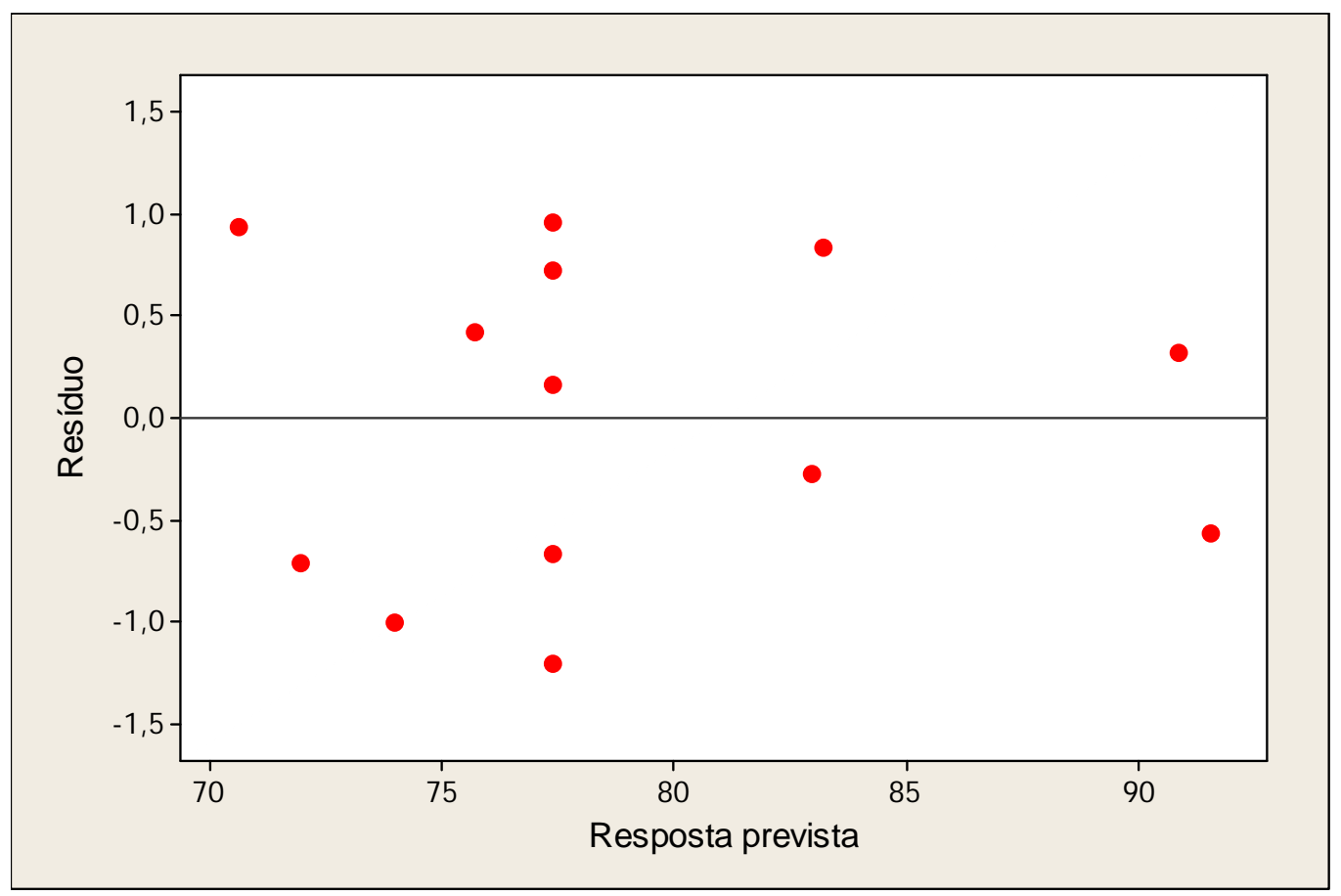

FIGURA 18 - Resíduos relativos ao modelo adotado para o ciclohexano.

\section{Estimativa da influência das variáveis sobre a resposta}

Os resultados de densidade relativa obtidos neste planejamento mostram um aumento da resposta de interesse com uma maior quantidade de ACP e o emprego de um menor tempo de moagem, de forma semelhante ao verificado no planejamento de experimentos do metanol. Entretanto, para o ciclohexano, o efeito do tempo de moagem foi muito mais pronunciado, notando-se que a influência da quantidade de ACP foi mais expressiva somente para tempos inferiores a 60 minutos. Em relação à condição padrão, a melhoria proporcionada à densidade foi superior a $13 \%$, sendo o maior valor $(91,18 \%)$ registrado para 18 minutos de moagem com $1,0 \%$ do agente. Os pós moídos por 30 minutos com $1,5 \%$ de ciclohexano também resultaram em uma melhoria significativa na resposta, observando-se uma densidade de 90,96\% no experimento realizado nesta condição. Contudo, apesar do evidente aumento na densificação das pastilhas, os melhores resultados obtidos para o ciclohexano são inferiores aos observados com a utilização dos outros agentes. 
$\mathrm{Na}$ TAB. 16 é apresentada a estimativa dos termos da equação de regressão. A expressão que descreve o modelo quadrático ajustado para a região investigada é apresentada na equação 5.5 .

$$
\begin{aligned}
& \hat{y}_{\text {chex }}=77,36-7,1541 x_{1}+2,6405 x_{2}+1,6890 x_{1}^{2}+1,0360 x_{2}^{2}-1,6350 x_{1} x_{2}(5.5)
\end{aligned}
$$

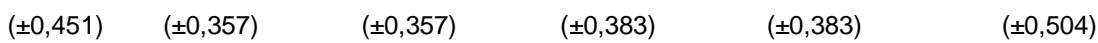

Novamente, como não houve evidência de falta de ajuste do modelo, a estimativa dos erros padrão dos parâmetros foi realizada com sete graus de liberdade, a partir dos resíduos verificados na equação de regressão.

TABELA 16 - Estimativa do grau de significância das variáveis para o ciclohexano.

\begin{tabular}{|c|c|c|c|c|c|}
\hline Variáveis & Efeitos & b & $\mathbf{s}_{\mathrm{b}}$ & $t_{7} \times s_{b}$ & I.C. \\
\hline $\begin{array}{c}\mathrm{b}_{0} \\
\text { (grande média) }\end{array}$ & - & 77,36 & 0,451 & 1,067 & $(76,293 ; 78,427)$ \\
\hline $\begin{array}{c}\mathrm{X}_{1} \\
\text { (tempo de moagem) }\end{array}$ & $-14,3082$ & $-7,1541$ & 0,357 & 0,844 & $(-7,9981 ;-6,3101)$ \\
\hline $\begin{array}{c}\mathrm{X}_{2} \\
\text { (quantidade de ACP) }\end{array}$ & 5,2810 & 2,6405 & 0,357 & 0,844 & $(1,7965 ; 3,4845)$ \\
\hline $\begin{array}{c}\mathrm{x}_{1}{ }^{2} \\
\text { (tempo de moagem })^{2}\end{array}$ & - & $-1,6890$ & 0,383 & 0,906 & $(-2,5950 ;-0,7830)$ \\
\hline $\begin{array}{c}\mathrm{x}_{2}{ }^{2} \\
\text { (quantidade de } \mathrm{ACP})^{2}\end{array}$ & - & $-1,0360$ & 0,383 & 0,906 & $(-1,9420 ;-0,1300)$ \\
\hline $\begin{array}{c}\mathrm{X}_{1} \mathrm{X}_{2} \\
\text { (tempo de moagem } \times \\
\text { quantidade de } \mathrm{ACP} \text { ) }\end{array}$ & $-3,2700$ & $-1,6350$ & 0,504 & 1,192 & $(-2,827 ;-0,4430)$ \\
\hline \multicolumn{3}{|c|}{$s=1,009$} & \multicolumn{3}{|c|}{$t_{7}=2,365$ a $95 \%$ de confiança } \\
\hline
\end{tabular}

$\mathrm{b}=$ coeficientes do modelo; $\mathrm{s}_{\mathrm{b}}=$ erro padrão dos coeficientes do modelo;

$\mathrm{s}=$ erro experimental; $\mathrm{t}_{7}=$ distribuição de Student com sete graus de liberdade; I.C. = intervalo de confiança. 
A expressão do modelo para o ciclohexano, juntamente com os resultados apresentados na TAB. 16, mostram que todos os termos são significativos no intervalo de confiança de $95 \%$, especialmente o termo linear negativo associado ao tempo de moagem. A equação indica que uma diminuição no tempo de moagem e a adição de uma maior quantidade de agente são favoráveis para aumentar a resposta. Além disso, os sinais negativos dos termos quadráticos e da interação indicam que a região ótima deve estar próxima das condições estudadas.

A superfície de resposta e as curvas de nível descritas pela equação 5.5 estão representadas nas FIG. 19 e 20. A região investigada apresenta um ponto de máximo localizado próximo de 18 minutos de moagem e 1,7\% de ciclohexano. Nessa condição, a estimativa para a densidade relativa é de aproximadamente $99 \%$, representando uma melhoria de aproximadamente $22 \%$ em relação à condição padrão.

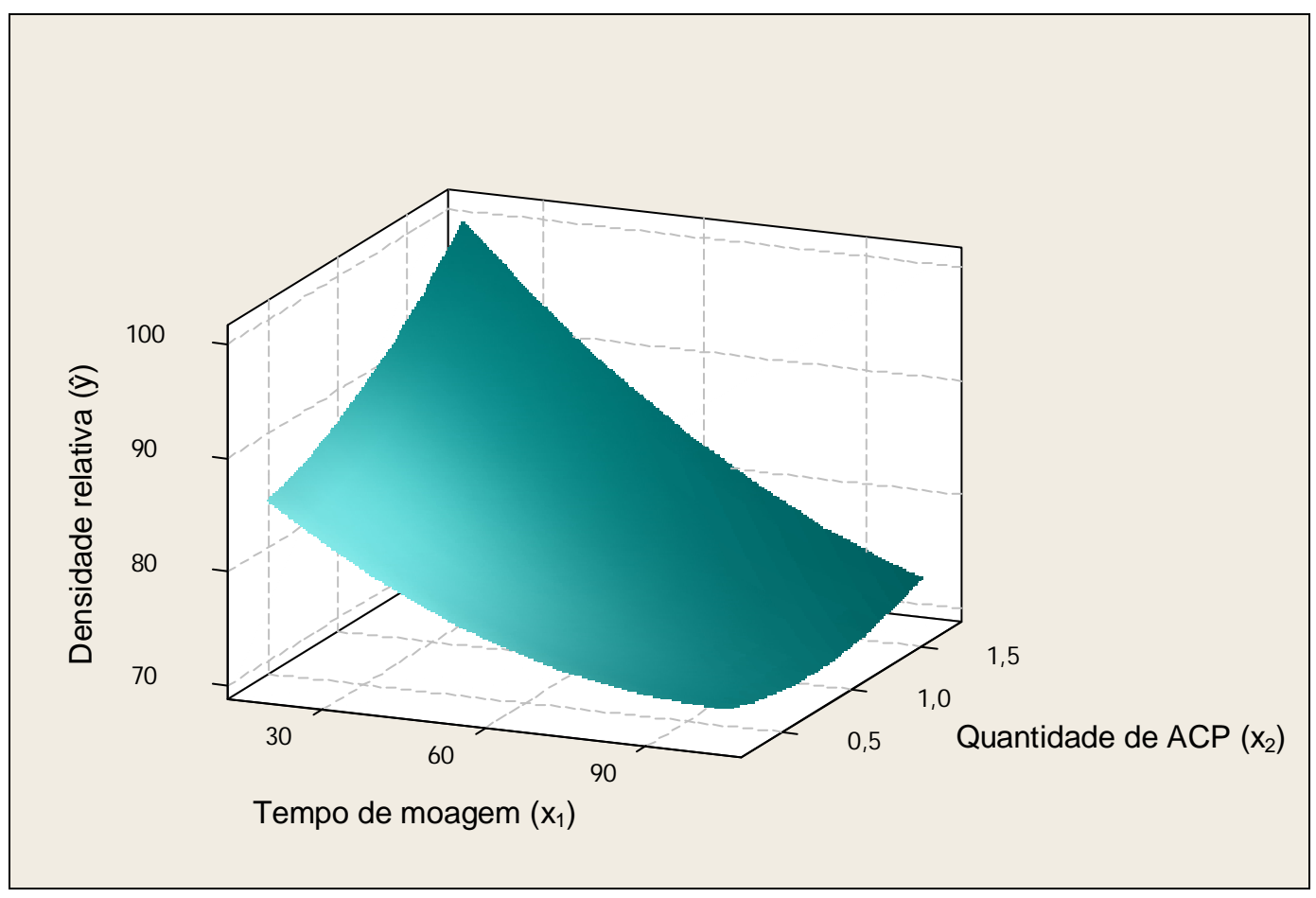

FIGURA 19 - Superfície de resposta descrita pela equação 5.5. 

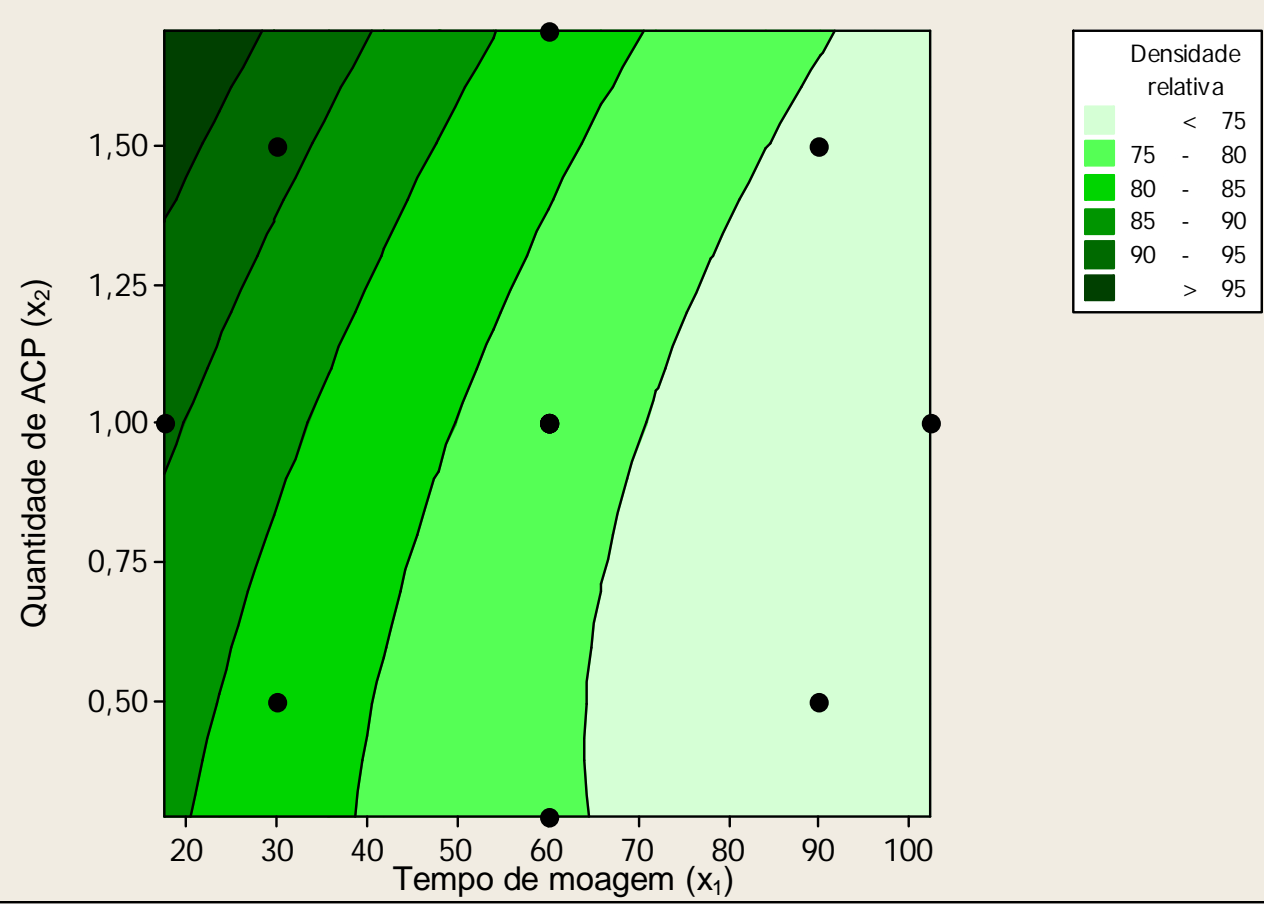

FIGURA 20 - Curvas de nível para a equação 5.5.

\subsubsection{Correlação entre os ACPs}

A elaboração dos planejamentos compostos centrais para cada ACP permitiu também verificar semelhanças e diferenças entre os comportamentos dos agentes em relação à resposta de interesse. As representações geométricas dos resultados obtidos com o ácido esteárico (FIG. 7) e o etanol (FIG. 11) indicaram a mesma direção para se obter maiores densidades relativas, na região investigada. Da mesma forma, com os agentes metanol e ciclohexano (FIG. 13 e 17, respectivamente), as tendências foram similares, sendo que a adição de uma maior quantidade de agente acarretou em maiores densidades para o $\mathrm{NbAl}_{3}$.

Considerando os agentes como variáveis, os coeficientes de correlação de Pearson, que representam uma medida da relação entre os ACPs, podem ser visualizados, numericamente, na TAB. 17. Tal como observado anteriormente, apenas as combinações entre os ACPs, a saber: ácido esteárico e etanol, metanol e ciclohexano, apresentaram uma correlação positiva considerada de moderada (metanol e ciclohexano) a forte (ácido esteárico e etanol). As demais combinações entre os agentes não apresentaram uma correlação significativa. 
Graficamente, as correlações consideradas significativas entre as densidades relativas utilizando os diferentes tipos de ACPs são apresentadas nas FIG. 21 e 22.

TABELA 17 - Correlação entre os ACPs.

\begin{tabular}{|c|c|c|c|}
\cline { 2 - 4 } \multicolumn{1}{c|}{} & Etanol & Metanol & Ciclohexano \\
\hline Ácido esteárico & $\mathbf{0 , 8 8 0}$ & 0,567 & 0,214 \\
\hline Etanol & - & 0,298 & $-0,173$ \\
\hline Metanol & - & - & $\mathbf{0 , 7 6 5}$ \\
\hline
\end{tabular}

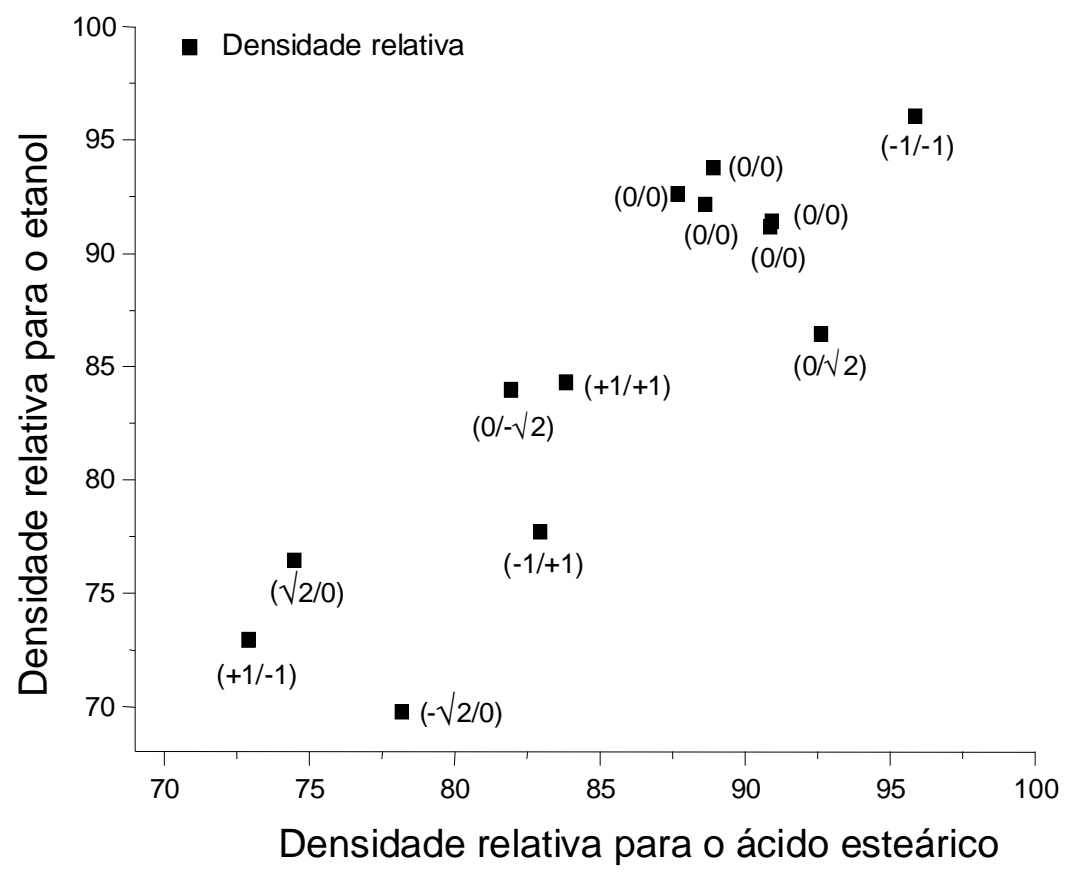

FIGURA 21 - Representação gráfica da correlação entre as densidades relativas obtidas para os agentes ácido esteárico e etanol. 


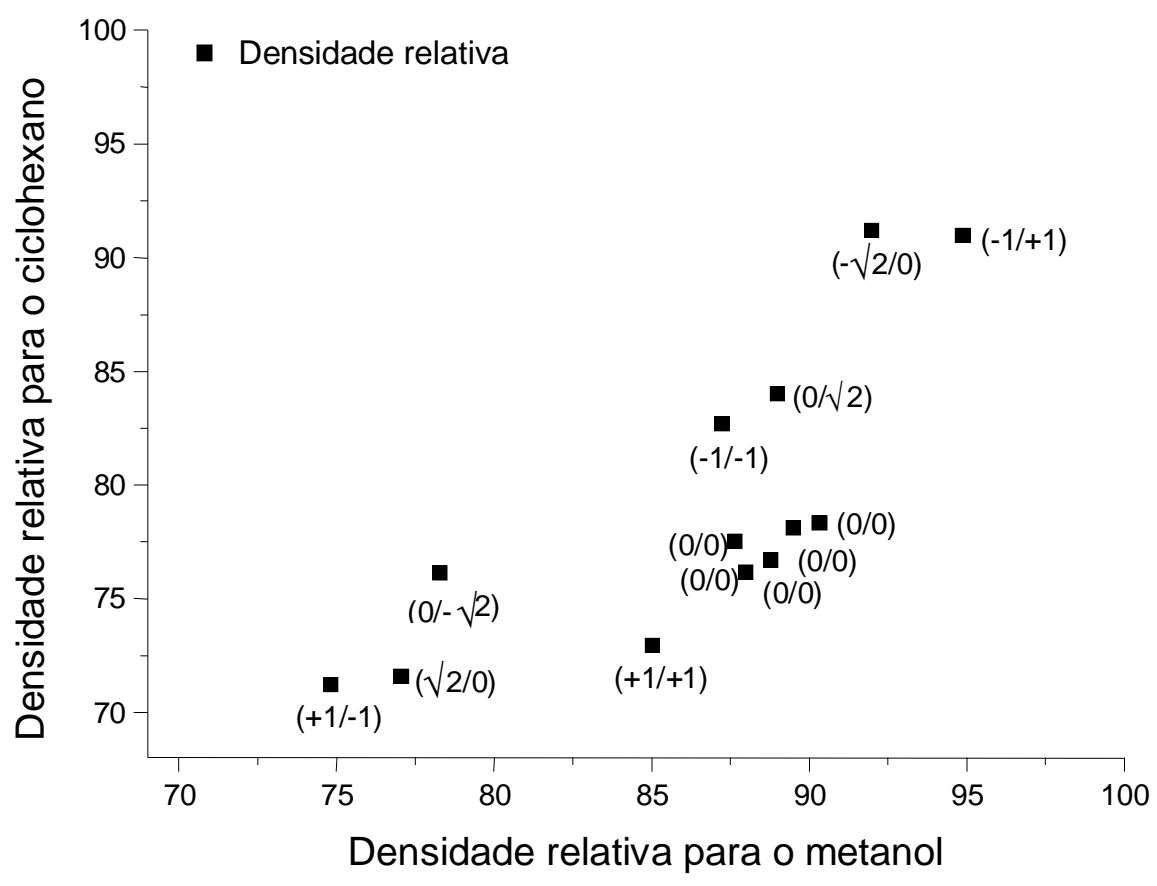

FIGURA 22 - Representação gráfica da correlação entre as densidades relativas obtidas para os agentes metanol e ciclohexano.

\subsubsection{Síntese dos principais resultados obtidos nos planejamentos}

Os resultados apresentados nos planejamentos compostos centrais para cada ACP mostraram que é possível obter um aumento nas densidades relativas das pastilhas de $\mathrm{NbAl}_{3}$ em relação à condição padrão. Essa melhoria foi obtida com a diminuição do tempo de moagem, associada a uma também redução nas quantidades de ácido esteárico e etanol, e a maiores adições de metanol e ciclohexano. O aumento nas densidades em relação ao ponto central foi mais significativo para o ciclohexano e menos pronunciado para o etanol.

$\mathrm{Na}$ TAB. 18 são apresentados os resultados das densidades obtidas para cada ACP na condição que revelou a maior densidade e no ponto central (60 minutos e 1,0\%). Observa-se que o agente etanol, mesmo na condição padrão, apresentou uma densidade mais elevada $(92,12 \%)$ do que o ciclohexano em uma condição otimizada $(91,18 \%)$. As pastilhas mais densas foram obtidas com a utilização dos agentes etanol e ácido esteárico, seguido do metanol e 
ciclohexano. Essa mesma sequência também foi observada nas densidades obtidas na condição padrão, indicando que os efeitos do etanol e ácido esteárico são mais pronunciados do que os dos outros ACPs, na região investigada.

Na TAB. 19 são apresentados os modelos adotados nos planejamentos de cada ACP.

TABELA 18 - Densidades obtidas nas condições de maior densidade e padrão (indicadas entre parênteses).

\begin{tabular}{|c|c|c|c|}
\hline ACP & $\begin{array}{c}\text { Tempo de moagem } \\
\text { (minutos) }\end{array}$ & $\begin{array}{c}\text { Quantidade de ACP } \\
\mathbf{( \% )}\end{array}$ & $\begin{array}{c}\text { Densidade relativa } \\
\left(\% \mathbf{d}_{\mathbf{t}}\right)^{*}\end{array}$ \\
\hline Ác. esteárico & 30 & 0,5 & $95,88(89,41)$ \\
\hline Etanol & 30 & 0,5 & $96,05(92,12)$ \\
\hline Metanol & 30 & 1,5 & $94,88(88,85)$ \\
\hline Ciclohexano & 18 & 1,0 & $91,18(77,36)$ \\
\hline
\end{tabular}

${ }^{*} d_{t}=4,54 \mathrm{~g} / \mathrm{cm}^{3}$ (densidade teórica do $\mathrm{NbAl}_{3}$ ).

TABELA 19 - Modelo adotado no planejamento de cada ACP.

\begin{tabular}{|c|c|}
\hline ACP & Equação de regressão do modelo \\
\hline $\begin{array}{l}\text { Ácido } \\
\text { esteárico* }\end{array}$ & 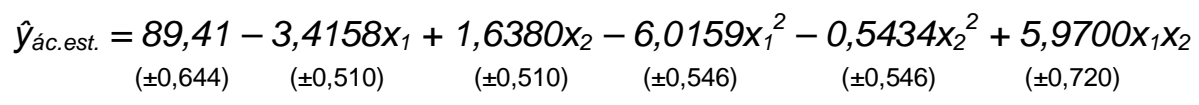 \\
\hline Etanol** & 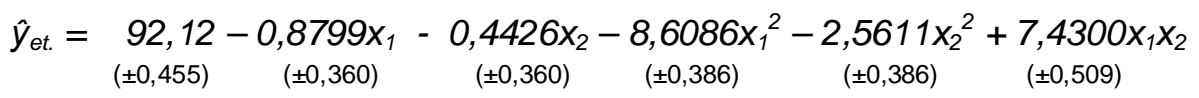 \\
\hline Metanol & $\hat{y}_{\text {met. }}=\underset{( \pm 0,531)}{88,85}-\underset{( \pm 0,420)}{5,4223 x_{1}}+\underset{( \pm 0,420)}{4,1281 x_{2}}-\underset{( \pm 0,450)}{1,8073 x_{1}^{2}}-\underset{( \pm 0,450)}{2,2548 x_{2}^{2}}+\underset{( \pm 0,593)}{0,6425 x_{1}} x_{2}$ \\
\hline Ciclohexano & $\hat{y}_{\text {chex. }}=\underset{( \pm 0,451)}{77,36}-\underset{( \pm 0,357)}{7,1541 x_{1}}+\underset{( \pm 0,357)}{2,6405 x_{2}}+\underset{( \pm 0,383)}{1,6890} x_{1}^{2}+\underset{( \pm 0,383)}{1,0360 x_{2}^{2}}-\underset{( \pm 0,504)}{1,6350} x_{1} x_{2}$ \\
\hline
\end{tabular}

*Estimativa da equação de regressão do modelo no nível de confiança de $99 \%$.

** Estimativa da equação de regressão do modelo com 95\% de confiança. O modelo apresentou falta de ajuste significativa. Os termos estimados indicam as variáveis significativas, porém seus valores numéricos não são precisos. 
As equações de regressão adotadas para o ácido esteárico e etanol apresentaram uma pequena falta de ajuste no nível de confiança de 95\%, sendo esta mais pronunciada para o etanol. No caso do ácido esteárico, o nível de significância para a falta de ajuste foi minimizado no intervalo de confiança de 99\%. Nos modelos dos agentes metanol e ciclohexano, não foi evidenciada nenhuma falta de ajuste, sendo amplamente satisfeitas as condições para fins de previsão e possibilitando a construção das superfícies de resposta para esses dois ACPs. As semelhanças entre as combinações dos agentes (ácido esteárico e etanol, metanol e ciclohexano) também foram observadas nos relativamente altos valores obtidos para os coeficientes de correlação de Pearson.

As faltas de ajuste observadas para o ácido esteárico e etanol, no nível de confiança de $95 \%$, aliadas às elevadas contribuições dos termos quadráticos e de interação verificadas nos seus modelos, podem ser mais um indício de que estes dois agentes apresentam uma influência mais significativa sobre a resposta, especialmente em menores tempos de moagem, revelando também uma dependência funcional mais complexa entre esses agentes. As acentuadas variações nas densidades obtidas em tempos inferiores a 60 minutos para esses ACPs sugerem que os deslocamentos das variáveis ocorreram muito rapidamente nessa faixa. A utilização de uma escala de variação dos fatores menos ampliada nessa região pode proporcionar uma melhor indicação da direção do ponto ótimo. Entretanto, apesar dos requisitos para validar o modelo não terem sido amplamente satisfeitos para o ácido esteárico e etanol, os resultados permitiram uma boa estimativa da influência das variáveis e da condição mais provável para otimizar a resposta de interesse. 


\subsection{Caracterização das misturas mecanicamente ativadas}

A caracterização dos pós moídos foi realizada com o intuito de alcançar um melhor entendimento da influência das variáveis (tipo e quantidade) relativas aos ACPs, notadamente no que concerne à otimização da densidade relativa do $\mathrm{NbAl}_{3}$, apresentada nos planejamentos de experimentos. Os resultados obtidos nas análises por microscopia eletrônica de varredura, distribuição granulométrica, análise de imagem quantitativa, difração de raios $X$ e espectroscopia no infravermelho são apresentados nos próximos itens.

\subsubsection{Forma e distribuição do tamanho de partículas}

A forma e distribuição do tamanho de partículas dos pós moídos (definidos neste trabalho como distribuição do tamanho dos agregados) por 60 minutos com 1,0\% dos ACPs (condição padrão) são apresentadas na FIG. 23.

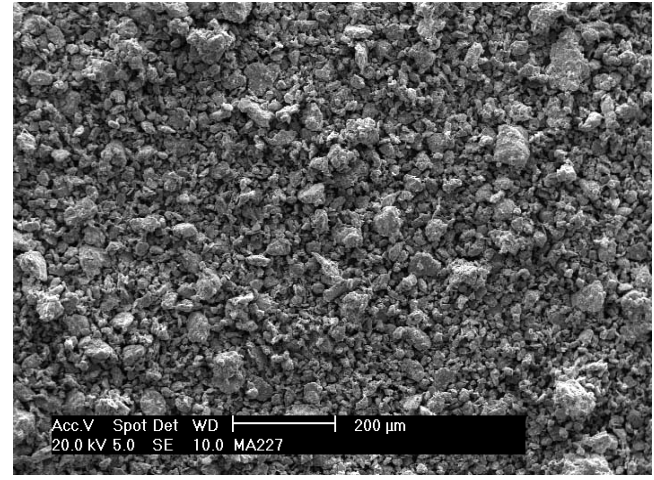

(a) Ácido esteárico $(89,41 \%)$

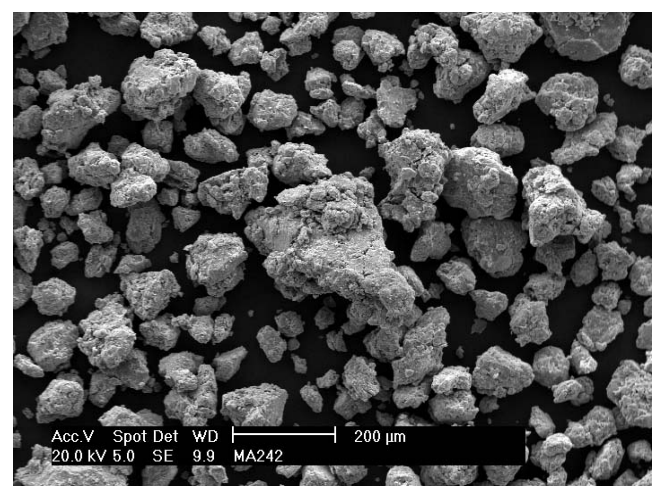

(c) Metanol $(88,85 \%)$

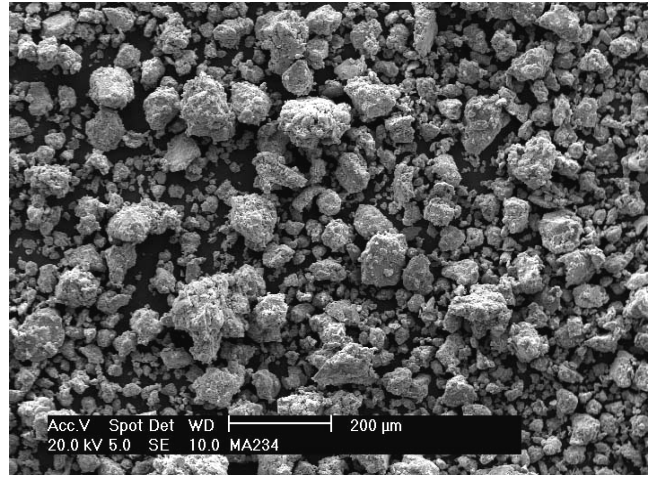

(b) Etanol $(92,12 \%)$

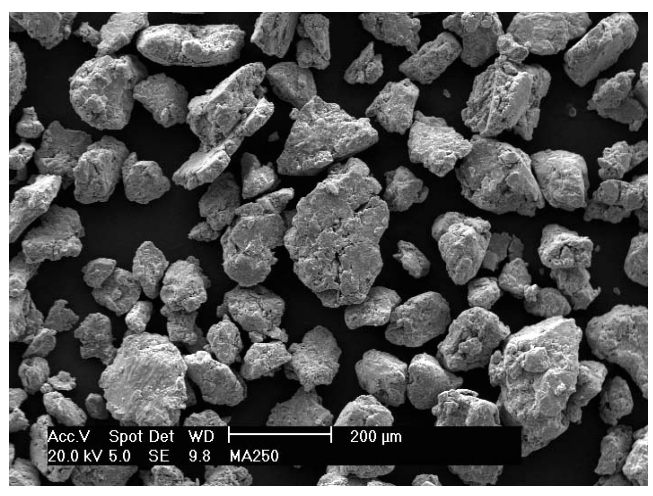

(d) Ciclohexano $(77,36 \%)$

FIGURA 23 - Micrografias eletrônicas de varredura (elétrons secundários) dos pós moídos na condição padrão. O ACP, juntamente com a densidade obtida, está indicado em cada caso. 
Nessa condição de moagem, os agentes ácido esteárico e etanol foram mais efetivos para diminuir o tamanho dos agregados, ao passo que os pós moídos com metanol e ciclohexano apresentaram agregados grosseiros. Em todos os casos, foram observados agregados com formatos ligeiramente achatados e uma ampla dispersão nos seus tamanhos, notadamente para os ACPs etanol e metanol.

Na TAB. 20 são apresentados os resultados de distribuição granulométrica para as misturas moídas com ácido esteárico e etanol, na condição padrão. O menor tamanho médio de agregado foi obtido com o ácido esteárico (39,7 $\mu \mathrm{m})$.

TABELA 20 - Distribuição granulométrica dos pós moídos na condição padrão.

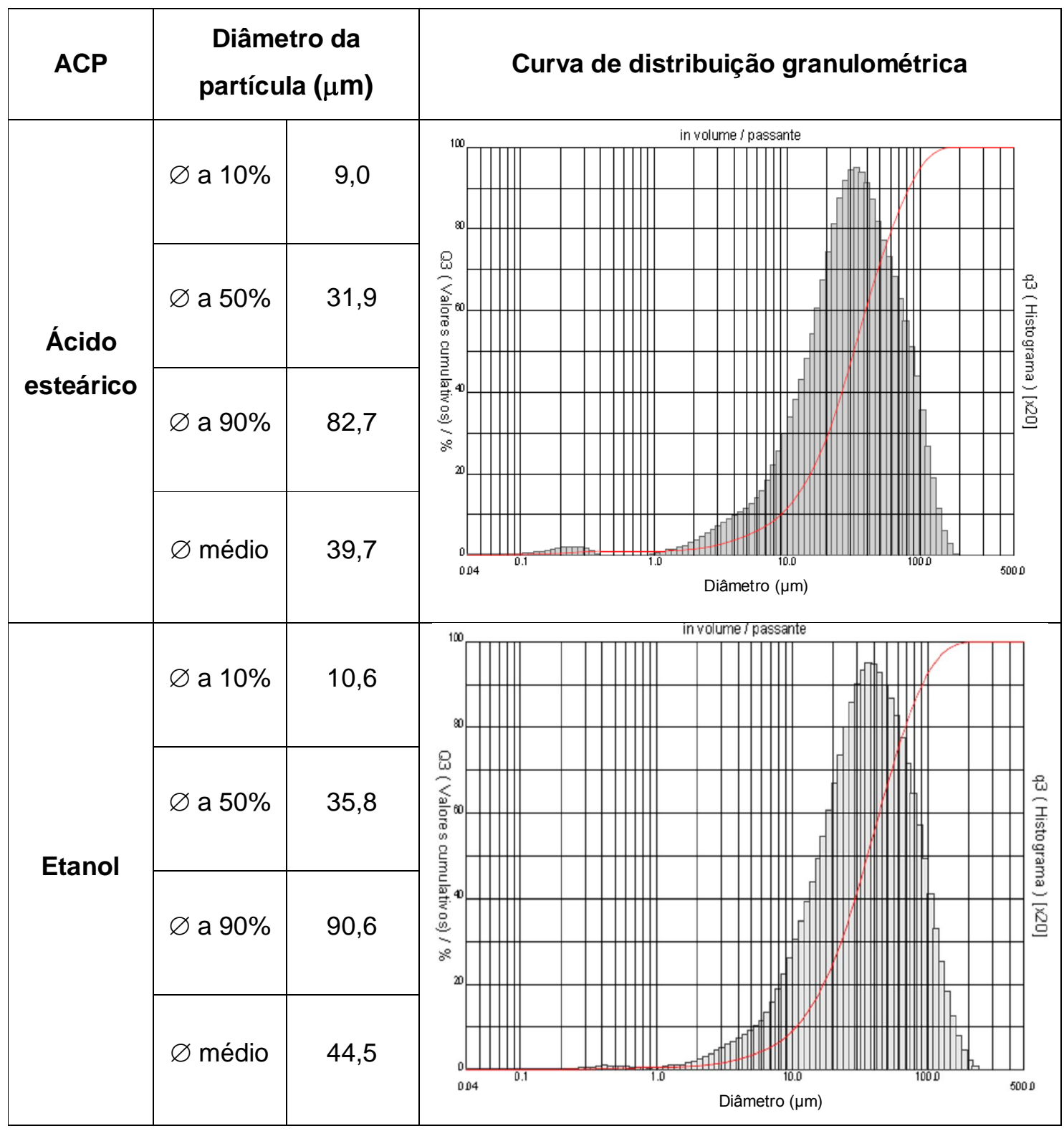


As análises de distribuição granulométrica na condição padrão para os agentes metanol e ciclohexano não foram realizadas, uma vez que esses ACPs apresentaram agregados grosseiros com tamanhos que chegaram a ultrapassar $500 \mu \mathrm{m}$, valor superior à faixa analítica do equipamento.

Segundo constatado por Shaw et al. (2003), pelo fato da ativação mecânica de sistemas dúcteis em tempos de moagem relativamente curtos produzir partículas com formatos achatados (comumente denominadas de flakes) e superfícies com elevada rugosidade, uma certa discrepância pode ser notada entre o tamanho de partícula observado nas micrografias e o determinado pelas técnicas de análise de distribuição granulométrica ou de superfície específica.

A influência da quantidade de ACP na forma e distribuição do tamanho dos agregados para os pós moídos por 30, 60 e 90 minutos é mostrada nas FIG. 24 a 26. As curvas de análise granulométrica foram obtidas para os agentes ácido esteárico, etanol e metanol, nos tempos de moagem de 30,60 e 90 minutos com $1,5 \%$ e $1,7 \%$ de adição desses agentes (TAB. 21 a 23). As curvas para o ciclohexano não foram determinadas em razão desse ACP ter sempre apresentado uma distribuição granulométrica muito heterogênea e com agregados superiores a $500 \mu \mathrm{m}$. Em todos os casos, esse agente mostrou-se ineficiente como inibidor da soldagem.

Um dos efeitos da adição de uma maior quantidade de ACP é o de produzir pós mais finos para um mesmo tempo de moagem, conforme exposto na expressão 3.1 do item 3.5.1. A análise das micrografias permite observar que a adição de uma maior quantidade de agente produziu uma alteração significativa na distribuição e no tamanho dos agregados das misturas moídas. Esse efeito foi mais pronunciado para o etanol e menos evidente para o ciclohexano.

A ativação mecânica para 30 minutos de moagem com 1,5\% de ACP produziu um menor tamanho de agregado em comparação com a condição padrão, notadamente para o etanol (FIG. 24). Nesse tempo de moagem, o tamanho médio do agregado obtido para este agente foi de $14,8 \mu \mathrm{m}$, ao passo que os diâmetros médios determinados para o ácido esteárico e metanol foram de 29,0 e 39,7 $\mu \mathrm{m}$, respectivamente (TAB 21). 
$0,5 \%$

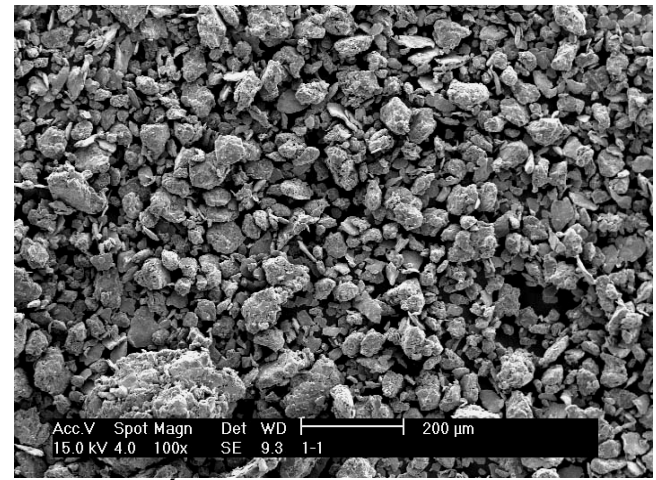

(a) Ácido esteárico $(95,88 \%)$

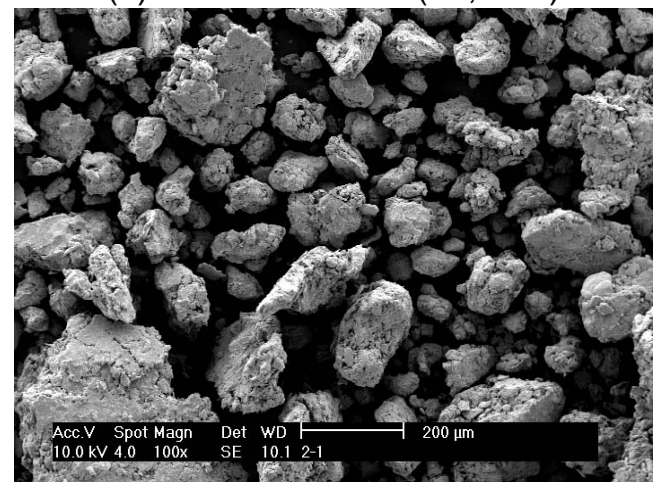

(c) Etanol $(96,05 \%)$

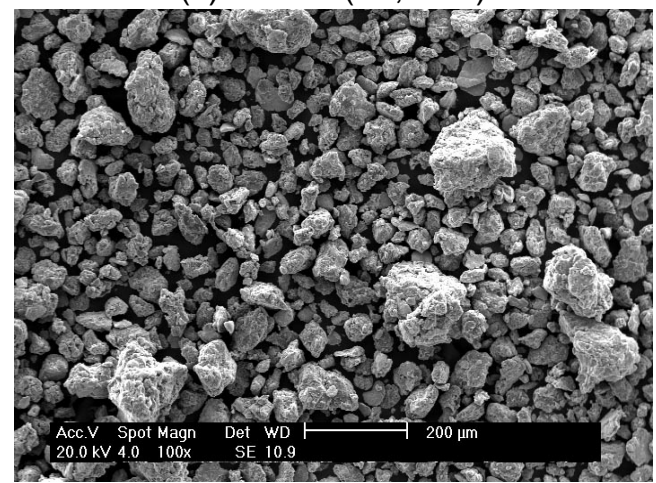

(e) Metanol $(87,24 \%)$

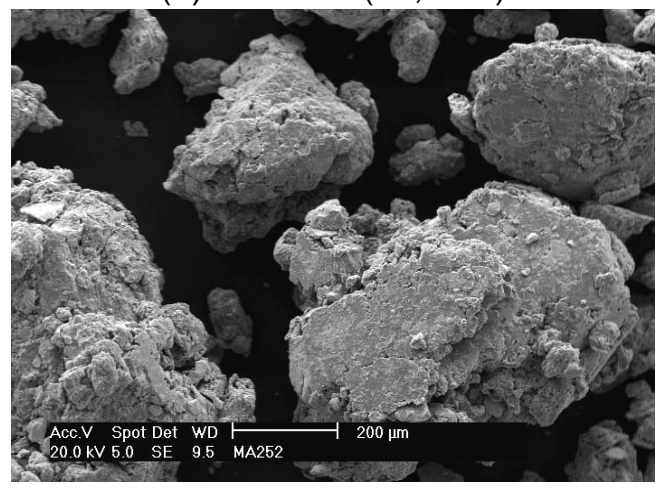

(g) Ciclohexano $(82,70 \%)$
$1,5 \%$

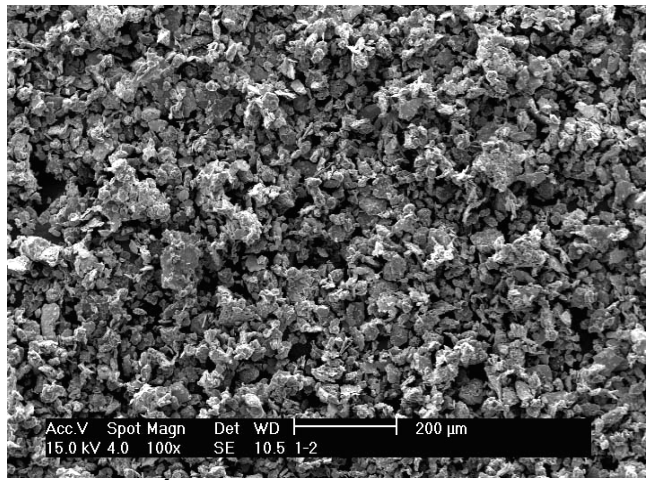

(b) Ácido esteárico $(82,94 \%)$

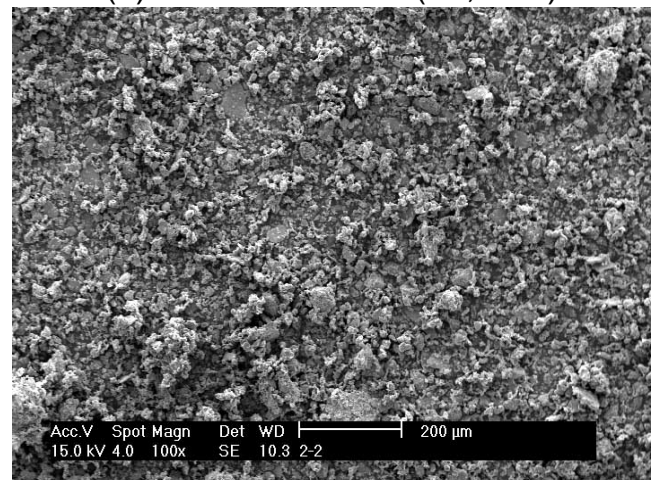

(d) Etanol $(77,68 \%)$

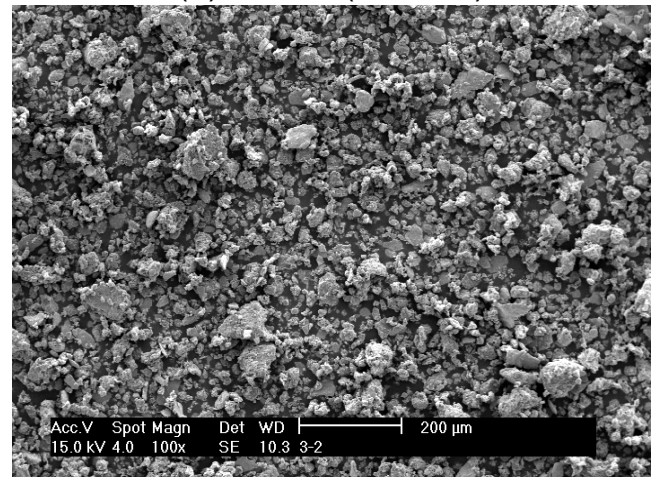

(f) Metanol $(94,88 \%)$

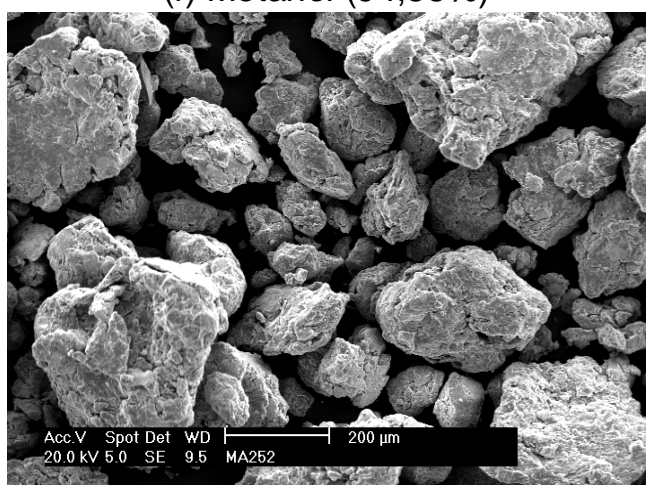

(h) Ciclohexano $(90,96 \%)$

FIGURA 24 - Micrografias eletrônicas de varredura (elétrons secundários) dos pós moídos por 30 minutos com 0,5 e 1,5\% de cada ACP. 
TABELA 21 - Distribuição granulométrica dos pós moídos por 30 minutos com $1,5 \%$ de cada ACP.

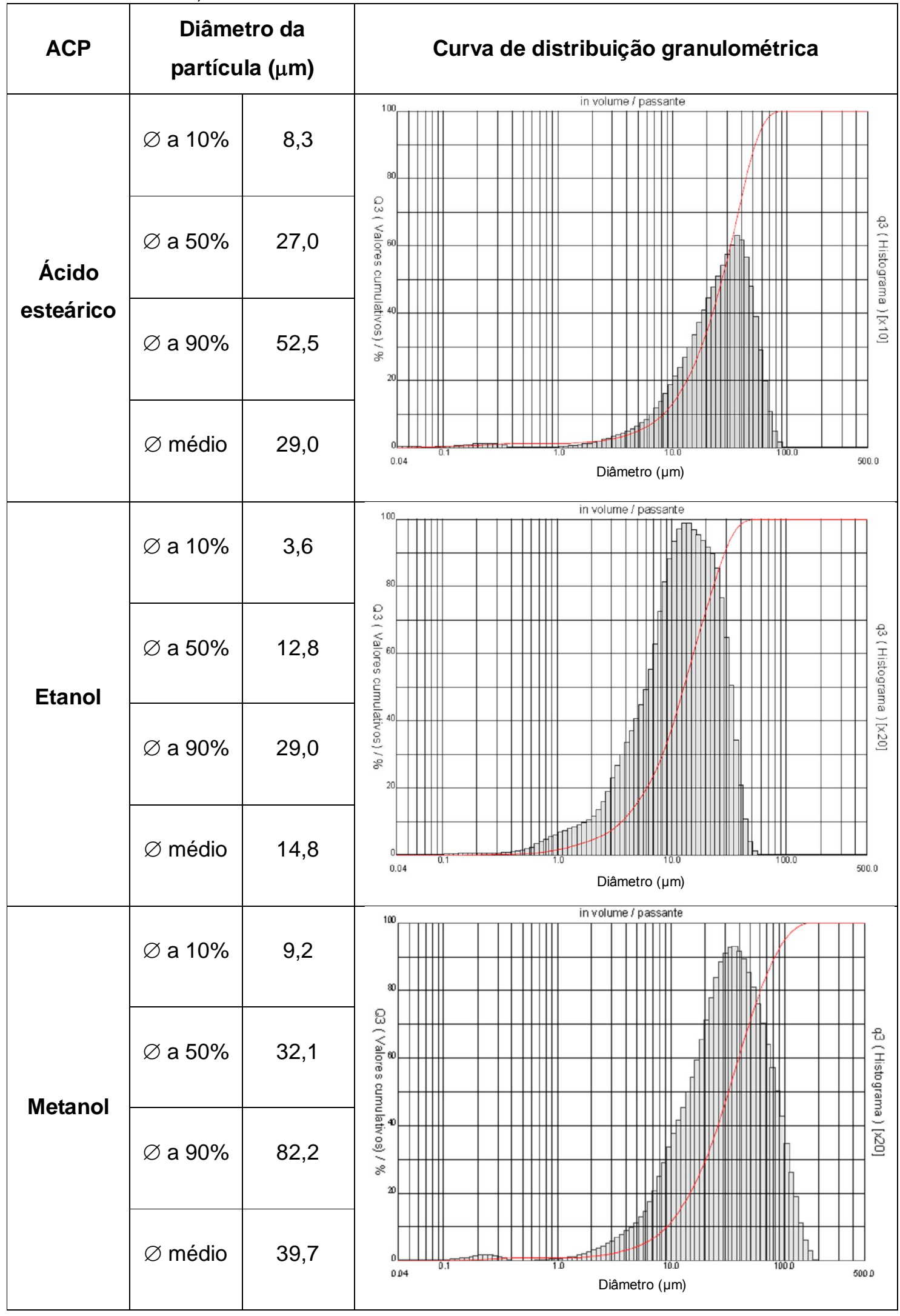


A observação da dispersão entre os tamanhos dos agregados (verificada pela diferença entre os diâmetros relativos a 90 e 10\%) das misturas moídas por 30 minutos com $1,5 \%$ de agente também permite constatar uma redução no tamanho de agregado de aproximadamente 1,5 vezes para o ácido esteárico e acima de três vezes para o etanol em relação à condição padrão.

$\mathrm{Na}$ FIG. 25 são apresentadas as micrografias dos pós moídos por 60 minutos com adições de 1,0\% (condição padrão) e 1,7\% dos ACPs. A análise visual das micrografias permite observar que os efeitos mais significativos na redução dos tamanhos dos agregados com a adição de uma maior quantidade de ACP foram obtidos para os agentes etanol e metanol. Novamente, é possível também constatar uma redução na amplitude da dispersão entre os tamanhos dos agregados em relação à condição padrão (TAB. 22).

A comparação entre as moagens realizadas por 90 minutos com 0,5 e 1,5\% dos ACPs é apresentada na FIG. 26. A utilização de uma menor quantidade de agente resultou em agregados maiores do que os obtidos na condição padrão. A exemplo do observado nas misturas moídas por 30 minutos, a adição de 1,5\% de ACP resultou em pós notadamente mais finos, especialmente para o etanol, sendo mais um indicativo de que uma pequena alteração na quantidade desse agente é capaz de alterar de forma pronunciada o tamanho dos agregados das misturas. Entretanto, tal efeito foi pouco significativo para o agente ciclohexano. Com relação às análises de distribuição granulométrica para 90 minutos de moagem com $1,5 \%$ dos agentes (TAB. 23$)$, o menor diâmetro médio $(20,4 \mu \mathrm{m})$ e a menor dispersão foram observados para o agente ácido esteárico, seguido do etanol $(26,5 \mu \mathrm{m})$ e metanol $(35,5 \mu \mathrm{m})$.

Como já era esperado, é importante notar que a influência da quantidade de ACP na distribuição e no tamanho dos agregados das misturas moídas foi superior ao efeito do tempo de moagem. Tal constatação é evidente nas micrografias apresentadas (FIG. 24 e 26) e nos resultados das análises de distribuição granulométrica (TAB. 21 e 23) para os pós moídos com 30 e 90 minutos. Observa-se que a adição de $1,5 \%$ de ACP resultou em um diâmetro médio e em uma distribuição no tamanho dos agregados muito semelhante para esses dois tempos de moagem. 
$1,0 \%$

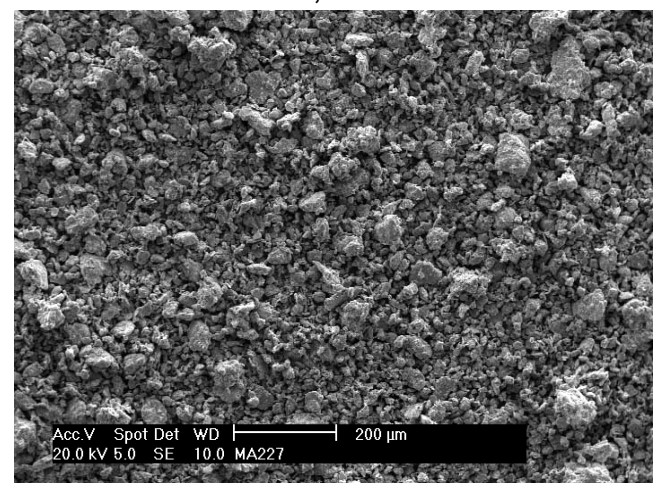

(a) Ácido esteárico $(89,41 \%)$

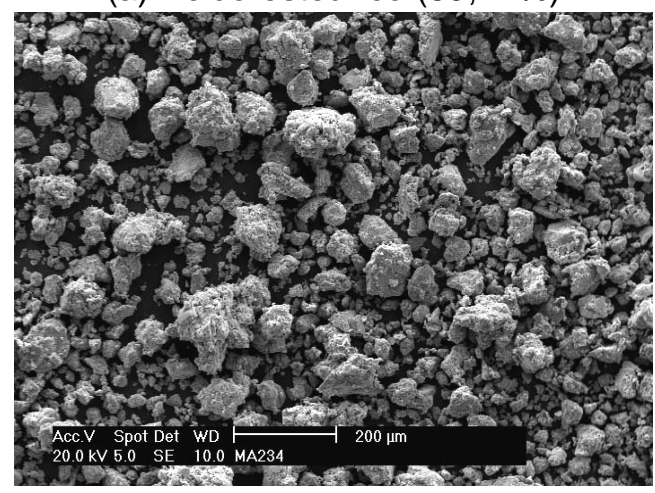

(c) Etanol $(92,12 \%)$

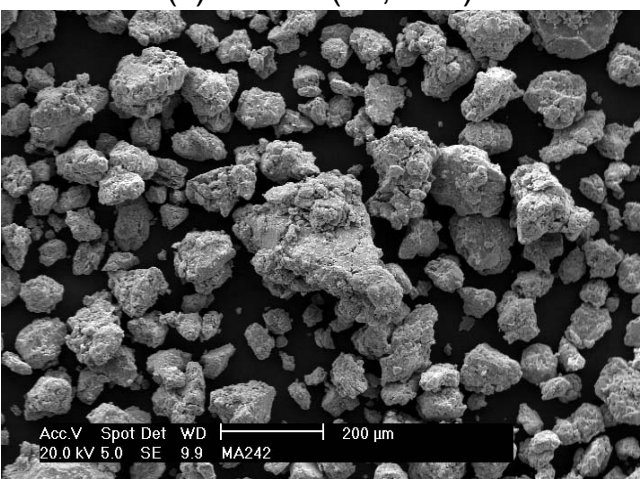

(e) Metanol $(88,85 \%)$

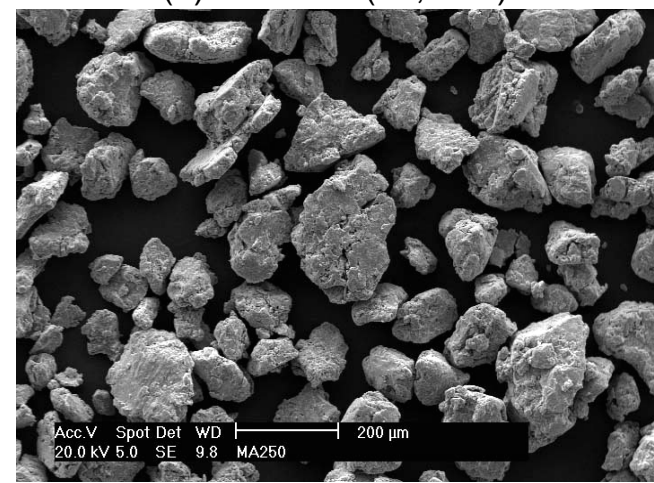

(g) Ciclohexano $(77,36 \%)$
$1,7 \%$

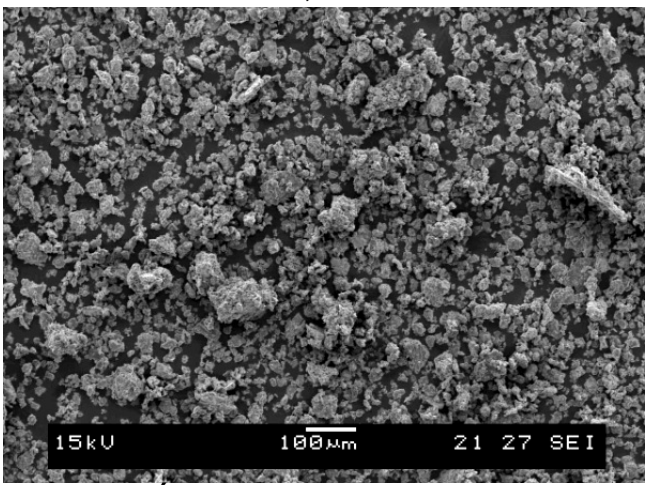

(b) Acido esteárico $(92,62 \%)$

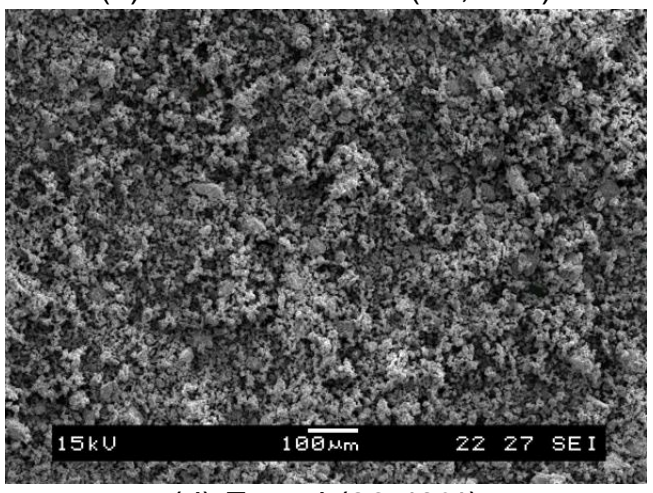

(d) Etanol $(86,43 \%)$

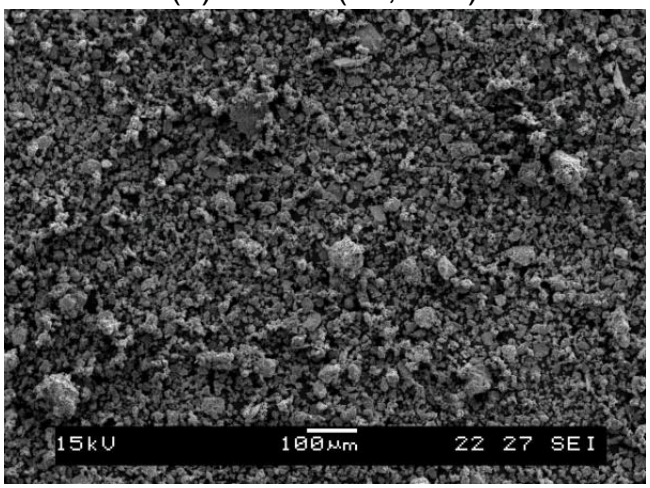

(f) Metanol $(89,00 \%)$

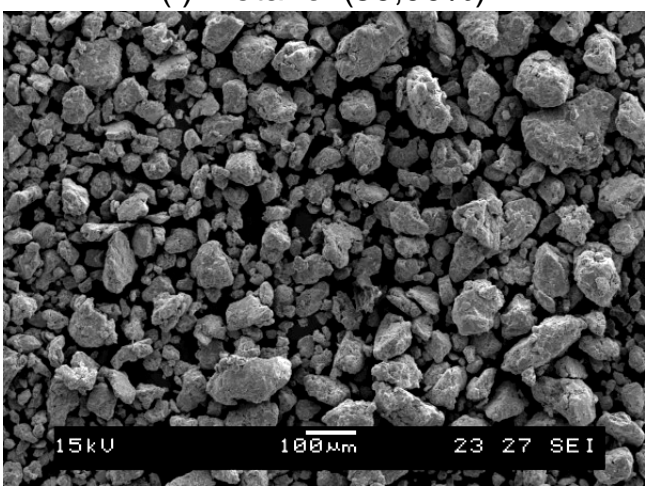

(h) Ciclohexano $(84,01 \%)$

FIGURA 25 - Micrografias eletrônicas de varredura (elétrons secundários) dos pós moídos por 60 minutos com 1,0 e 1,7\% de cada ACP. 
TABELA 22 - Distribuição granulométrica dos pós moídos por 60 minutos com $1,7 \%$ de cada ACP.

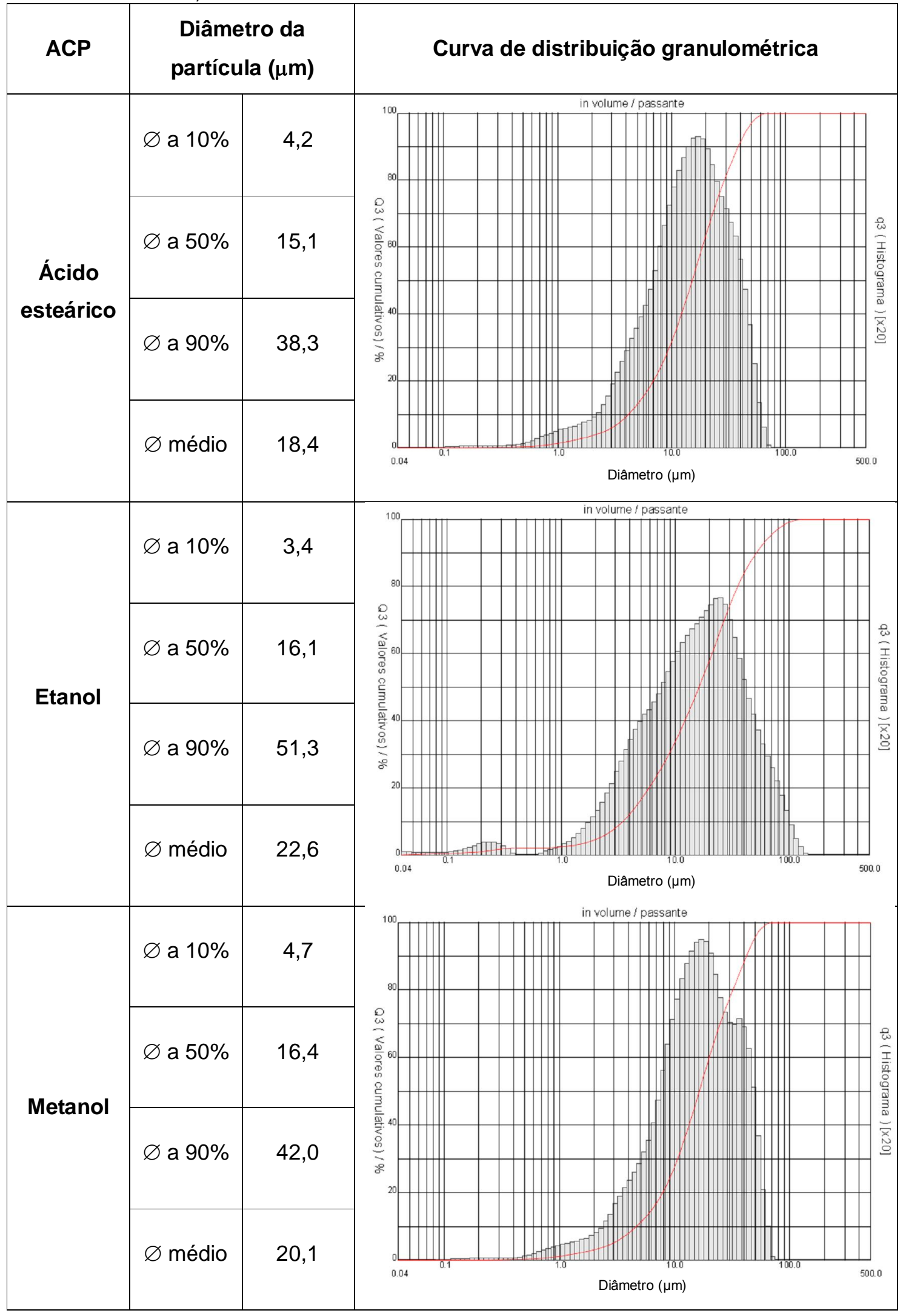




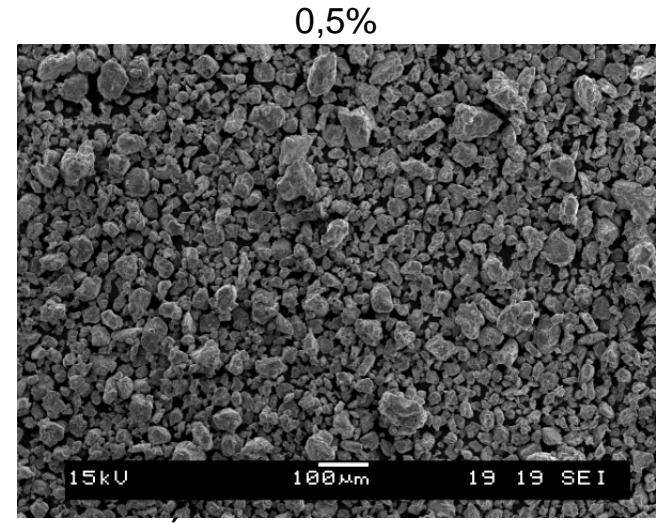

(a) Ácido esteárico (72,90\%)

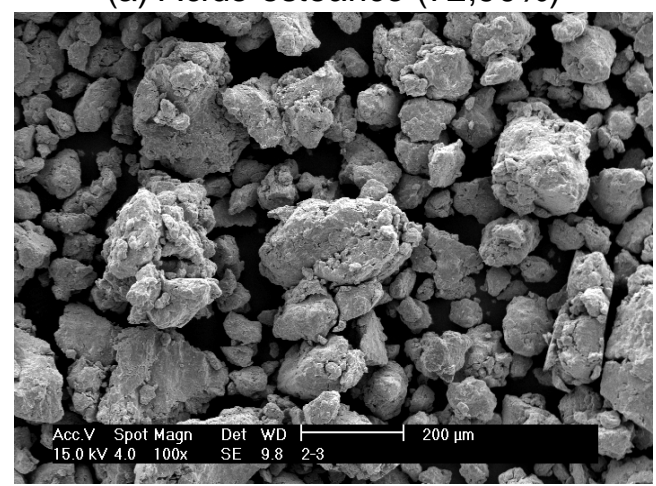

(c) Etanol $(72,94 \%)$

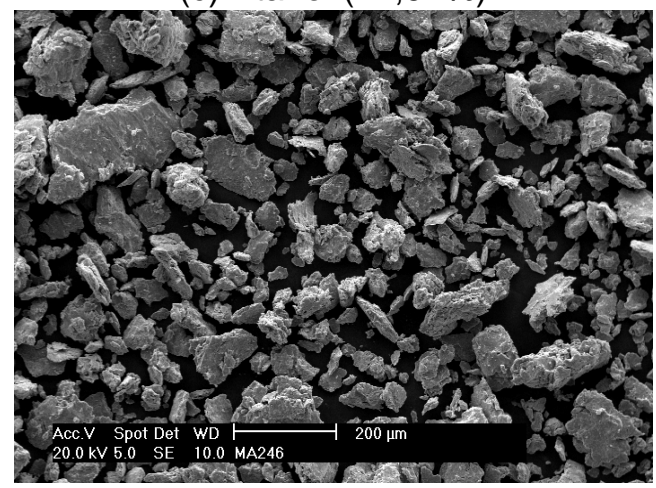

(e) Metanol (74,83\%)

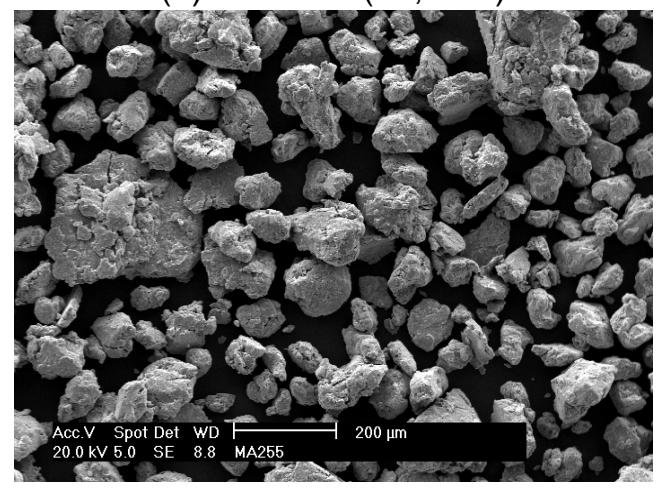

(g) Ciclohexano $(71,22 \%)$

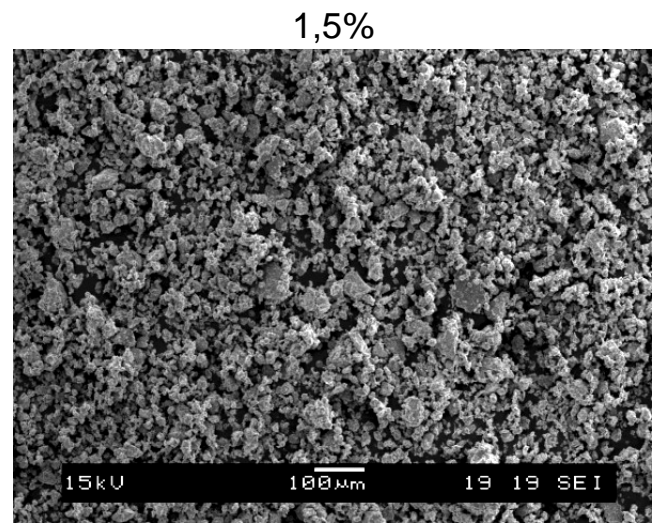

(b) Ácido esteárico $(83,84 \%)$

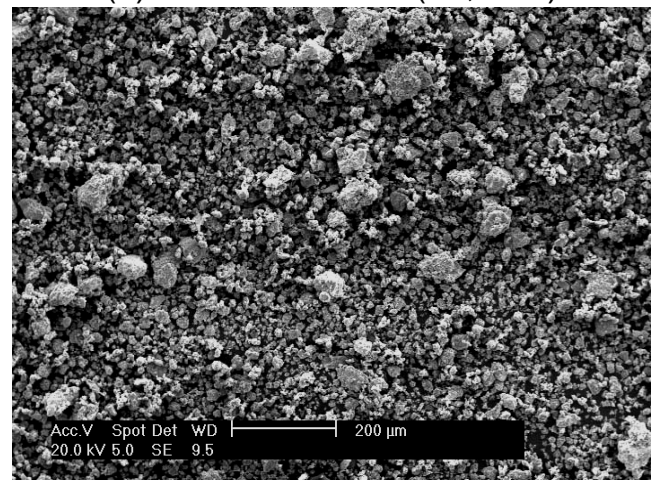

(d) Etanol $(84,29 \%)$

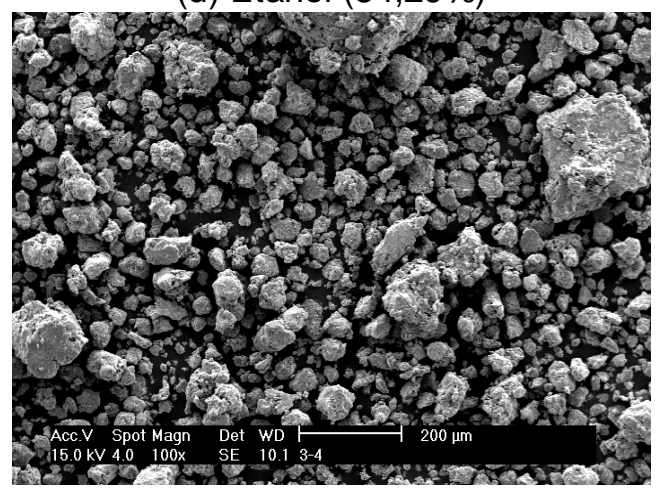

(f) Metanol $(85,04 \%)$

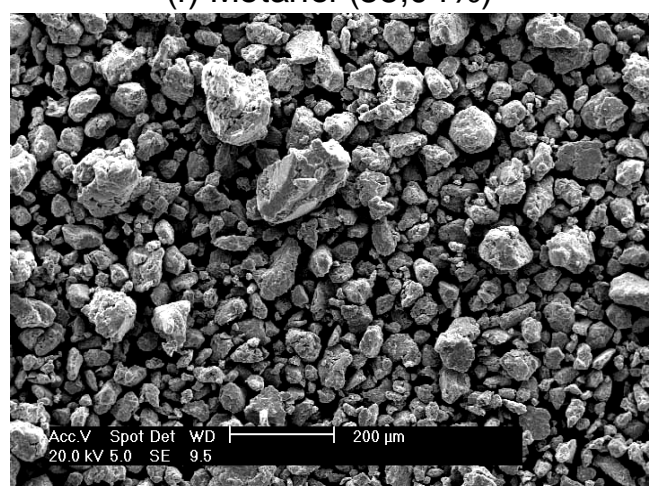

(h) Ciclohexano $(72,94 \%)$

FIGURA 26 - Micrografias eletrônicas de varredura (elétrons secundários) dos pós moídos por 90 minutos com 0,5 e 1,5\% de cada ACP. 
TABELA 23 - Distribuição granulométrica dos pós moídos por 90 minutos com $1,5 \%$ de cada ACP.

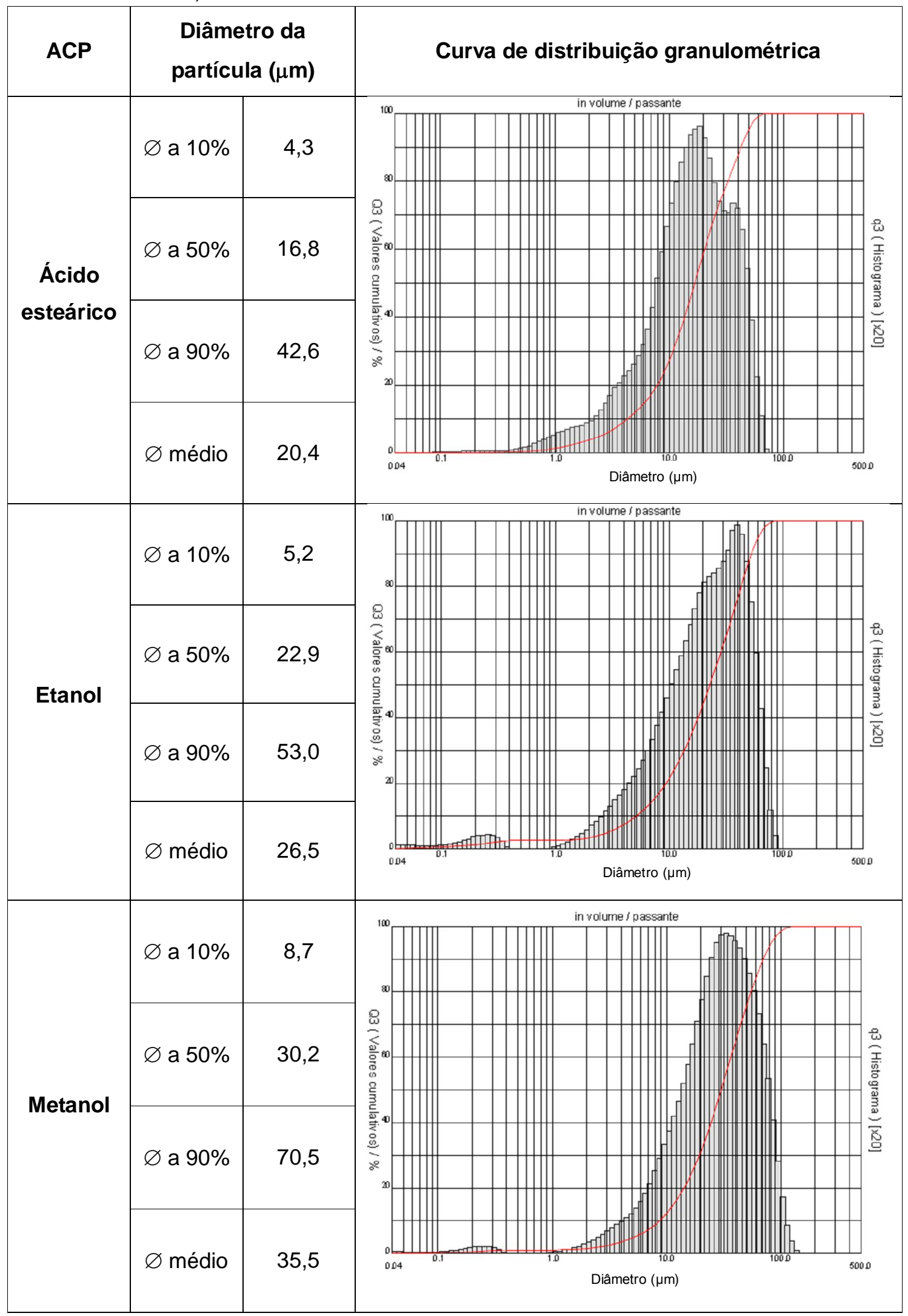




\subsubsection{Microestrutura das misturas mecanicamente ativadas}

Uma das conseqüências dos eventos de soldagem e fratura do processo de moagem com alta energia de materiais dúcteis e dissimilares é a formação de uma microestrutura composta por lamelas da fase menos dúctil (em geral, presente em uma menor fração volumétrica) incorporadas às partículas da fase mais dúctil (Benjamin e Volin, 1974; Lai e Lü, 1998). A análise das microestruturas obtidas nos pós moídos com os diferentes ACPs é de grande importância para tentar estabelecer uma associação entre estas e as densidades relativas obtidas após reação, bem como para alcançar um melhor entendimento da influência dos agentes no processo de ativação mecânica.

Na FIG. 27 são apresentadas as micrografias das misturas moídas na condição padrão com os diferentes tipos de ACPs. É possível observar a formação de agregados com microestrutura lamelar, constituídos pelos elementos nióbio (região clara) e alumínio (região cinza). A matriz escura que envolve as partículas e os agregados corresponde à resina de embutimento dos pós. Nas moagens com ácido esteárico, etanol e metanol, verificou-se a presença de partículas isoladas de nióbio (não associadas com o alumínio). A observação das micrografias permite também constatar que a moagem com ácido esteárico produziu agregados com uma microestrutura lamelar mais fina em comparação com os outros agentes. Esse fato pode estar associado a um menor tamanho dos agregados obtidos nas moagens com ácido esteárico na condição padrão (TAB. 20 do item 5.2.1).

Como uma tendência geral, as maiores densidades foram obtidas com 30 minutos de moagem (exceção para o ciclohexano que registrou uma densidade ligeiramente maior com 18 minutos), ao passo que os pós moídos por 90 minutos e $0,5 \%$ de ACP produziram pastilhas com menores densidades relativas (exceção para o etanol cuja densidade mais baixa foi obtida com 18 minutos de moagem). Na FIG. 28 é apresentada uma comparação entre as microestruturas obtidas com 30 e 90 minutos de moagem. É possível verificar a formação de agregados de nióbio e alumínio com características notadamente distintas, indicando diferentes estágios de ativação mecânica. Nas misturas moídas por 90 minutos (estágio de ativação mecânica mais avançado), observou-se uma estrutura lamelar altamente 
Dispersão dos agregados

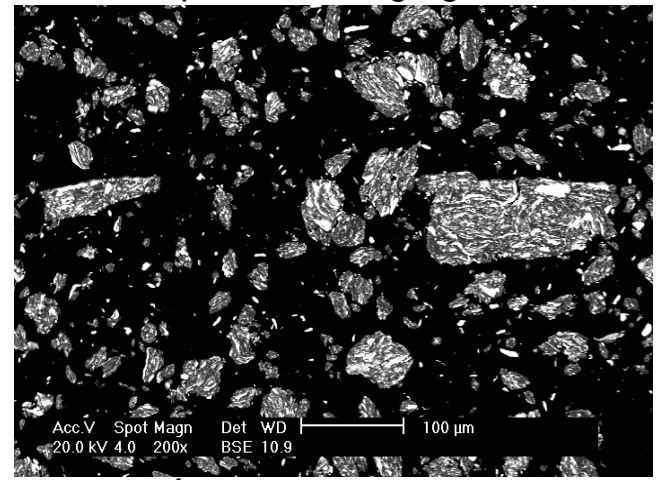

(a) Ácido esteárico $(89,41 \%)$

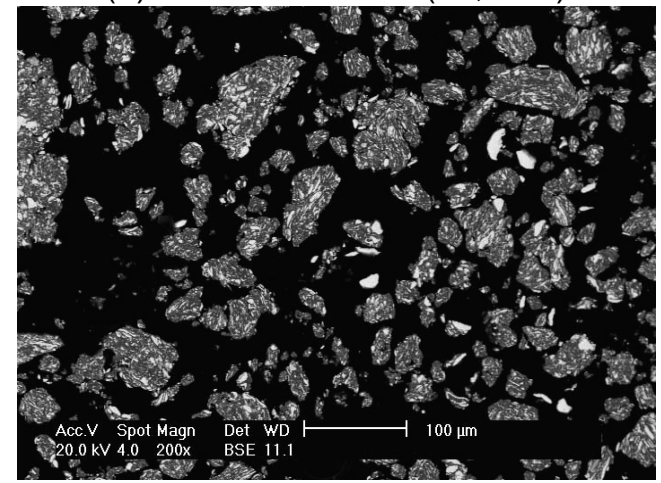

(c) Etanol $(92,12 \%)$

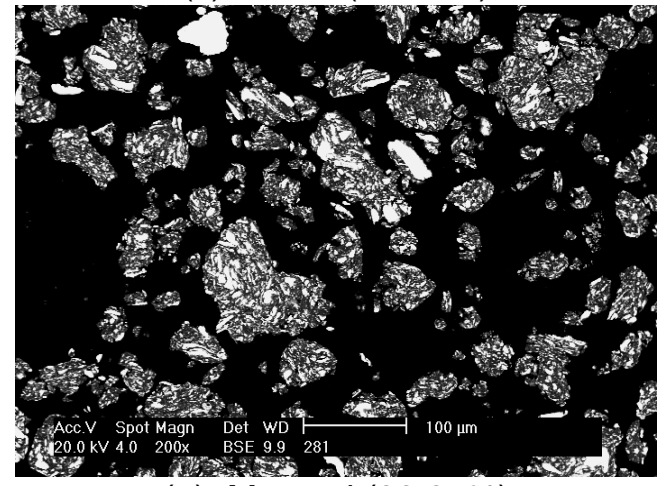

(e) Metanol $(88,85 \%)$

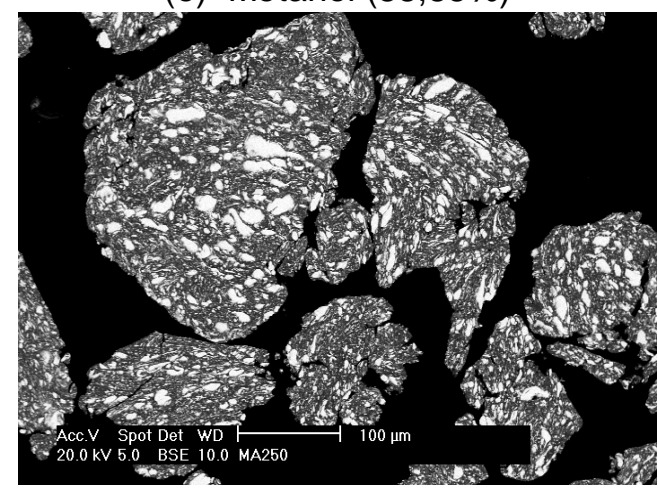

(g) Ciclohexano $(77,36 \%)$
Detalhe da microestrutura

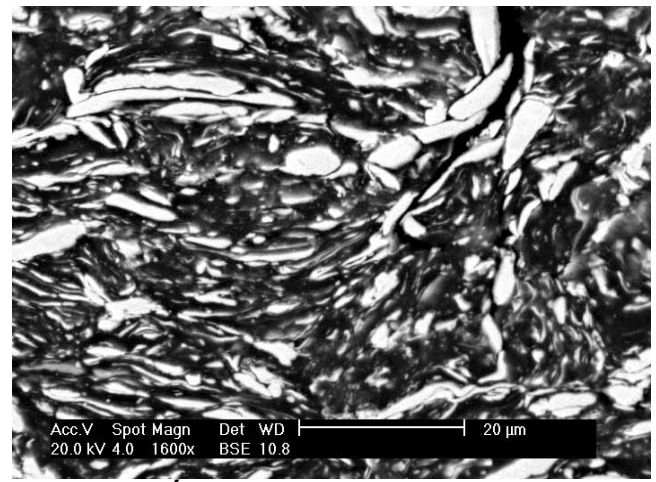

(b) Ácido esteárico $(89,41 \%)$

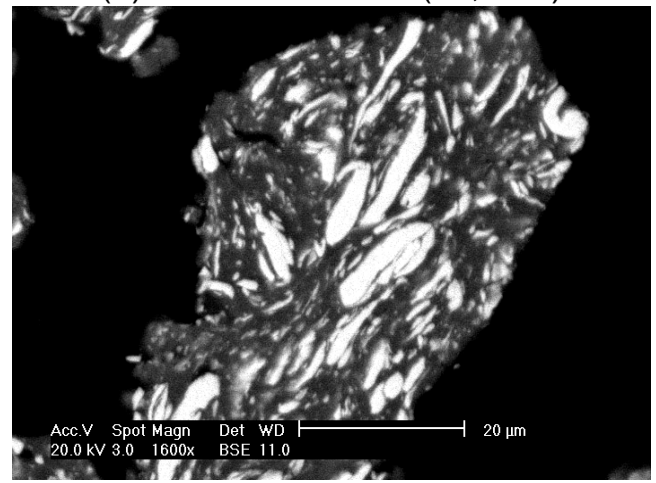

(d) Etanol $(92,12 \%)$

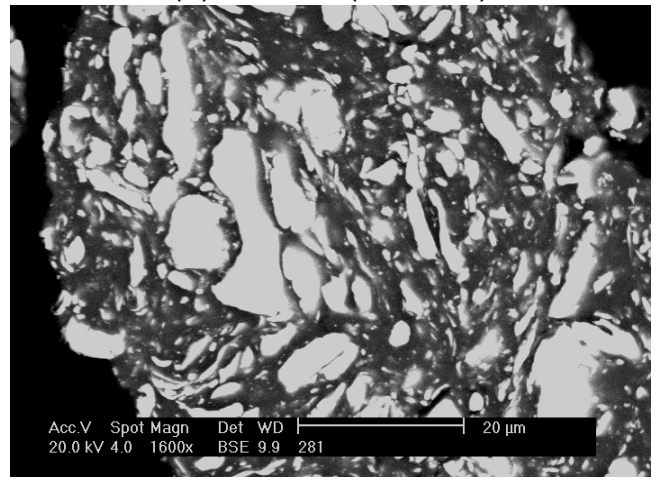

(f) Metanol $(88,85 \%)$

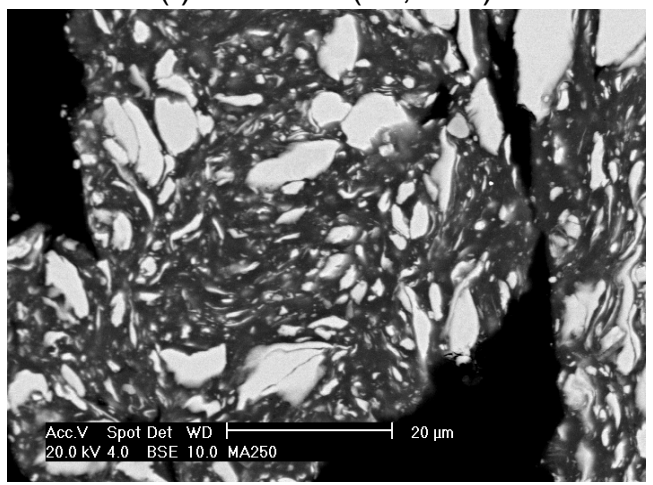

(h) Ciclohexano $(77,36 \%)$

FIGURA 27 - Micrografias eletrônicas de varredura (elétrons retroespalhados) dos pós moídos na condição padrão. O ACP, juntamente com a densidade obtida, está indicado em cada caso. 


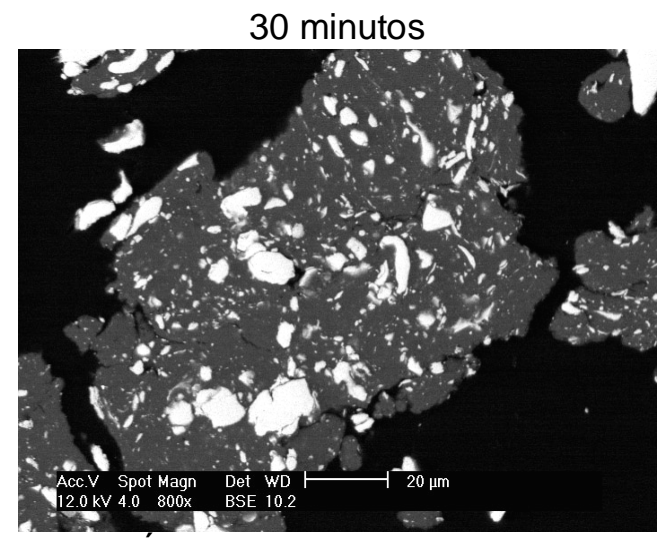

(a) Ác. esteárico: 0,5\% (95,88\%)

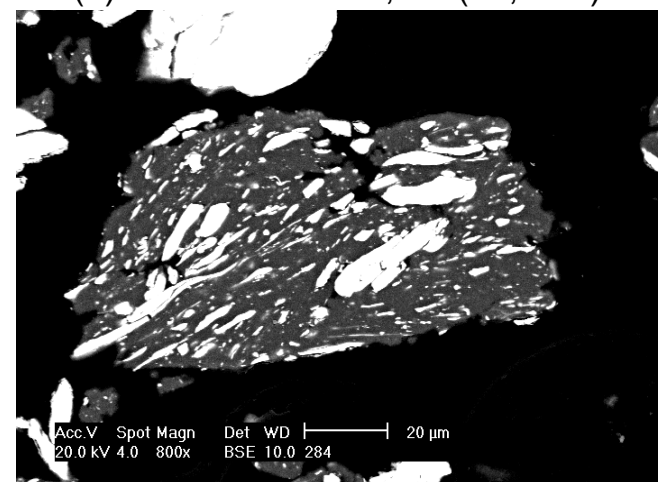

(c) Etanol: 0,5\% (96,05\%)

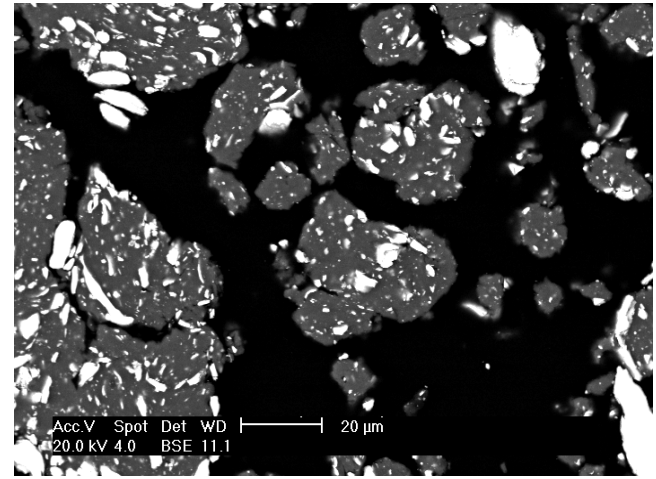

(e) Metanol: 1,5\% (94,88\%)

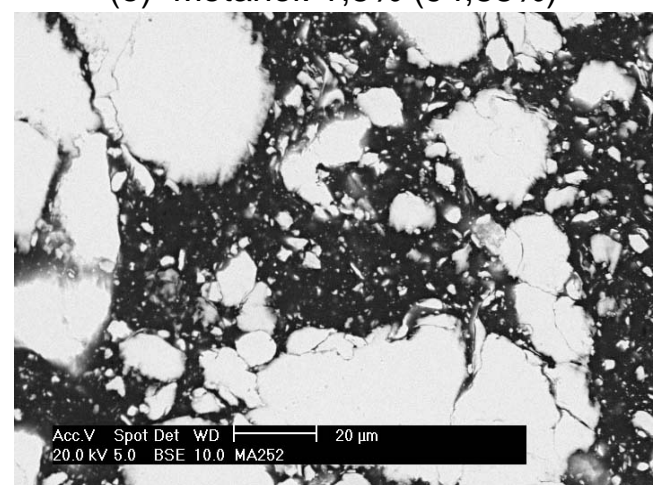

(g) Ciclohexano: $1,5 \%(90,96 \%)$

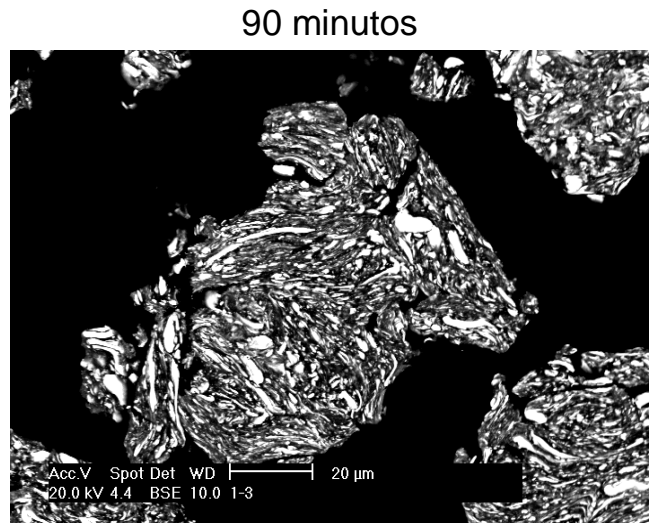

(b) Ác. esteárico: 0,5\% (72,90\%)

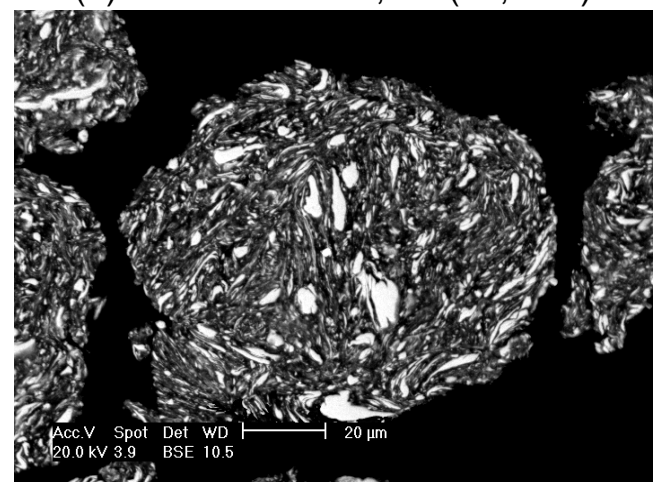

(d) Etanol: 0,5\% (72,94\%)

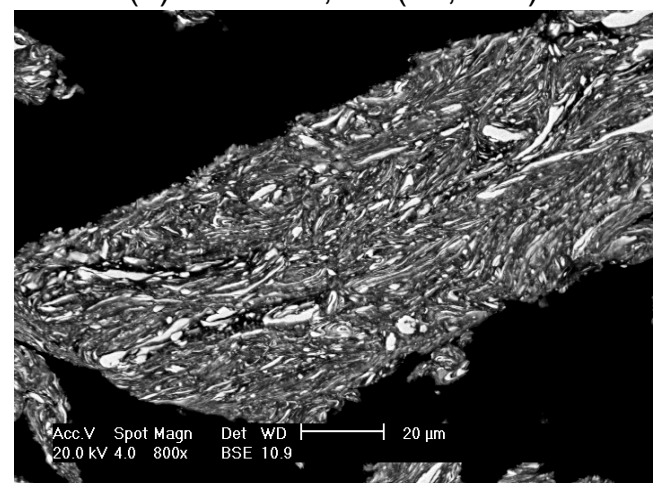

(f) Metanol: 0,5\% (74,83\%)

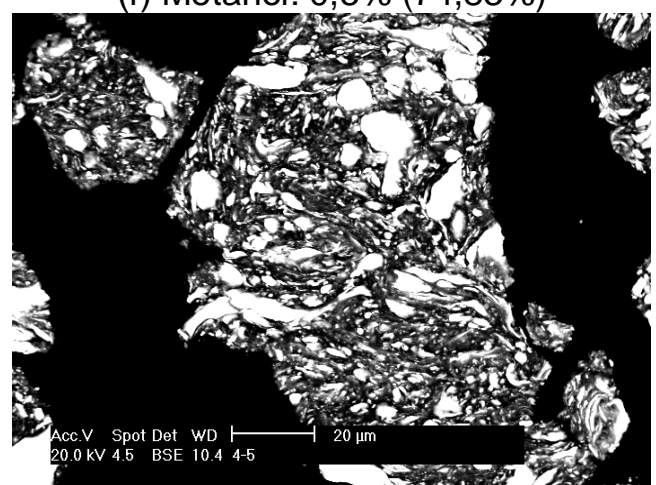

(h) Ciclohexano: 0,5\% (71,22\%)

FIGURA 28 - Micrografias eletrônicas de varredura (elétrons retroespalhados) dos pós moídos por 30 e 90 minutos. A quantidade de ACP utilizada está indicada em cada caso. 
refinada para o ácido esteárico, etanol e metanol, contrariamente ao observado nas moagens com 30 minutos. Nestas últimas (estágio de ativação mecânica inicial), verificou-se uma estrutura rica em alumínio contendo partículas incrustadas de nióbio. Somente o etanol apresentou agregados com estrutura mais semelhante à lamelar.

Os dados indicam que a produção de uma microestrutura lamelar refinada é prejudicial às densidades das pastilhas após reação, conforme verificado pelos baixos valores de densidades obtidos para 90 minutos de moagem. Acrescida à questão da microestrutura, a obtenção de agregados grosseiros também é desfavorável à densificação, fato que ajuda a explicar as baixas densidades obtidas com o agente ciclohexano.

Outro aspecto a ser considerado, além da microestrutura dos agregados, é a fração volumétrica de partículas isoladas (não associadas na forma de agregados) do elemento menos dúctil (no caso o nióbio).

Segundo Maurice e Courtney (1990), uma das conseqüências da adição de ACPs é o atraso na formação dos agregados pela supressão do evento de soldagem. Tal afirmação pode ser verificada também no trabalho de Rocha et al. (2003) pela presença de partículas isoladas de nióbio nos pós após moagem com alta energia. No presente estudo, considerando as misturas moídas por 30 e 60 minutos, as moagens realizadas com adições de 0,5\% (30 minutos) e 1,0\% (60 minutos) dos agentes apresentaram uma menor quantidade de partículas isoladas de nióbio (não associadas com o alumínio) em relação às adições com 1,5\% e 1,7\%, conforme pode ser observado nas FIG. 29 a 32.

Restringindo-se apenas às moagens com 30 minutos, a adição de uma maior quantidade de ACP resultou em uma microestrutura praticamente não lamelar, constituída por partículas de nióbio e alumínio altamente deformadas e achatadas, lembrando plaquetas (flakes). As diferenças verificadas entre as microestruturas com 0,5 e 1,5\% de ACP foram mais significativas para os agentes ácido esteárico e etanol (FIG. 29 e 30), e menos pronunciadas no caso do metanol e ciclohexano (FIG. 31 e 32). Este último apresentou estruturas muito semelhantes com 0,5 e 1,5\%, sendo a principal diferença detectada relacionada à diminuição no tamanho dos agregados com 1,5\% do agente. Para os ACPs ácido 
esteárico e etanol, as expressivas diferenças observadas nas microestruturas também foram refletidas nos resultados de densidade relativa das pastilhas reagidas. O etanol apresentou a maior dispersão (aproximadamente 18\%) entre os valores de densidade obtidos com 0,5 e 1,5\% de adição do agente.

Nas moagens realizadas por 60 minutos, a comparação entre as microestruturas obtidas com 1,0 e 1,7\% de cada agente revelou microestruturas muito semelhantes para o ácido esteárico, metanol e ciclohexano. Em relação às misturas moídas por 30 minutos, as moagens com 60 minutos apresentaram um aspecto mais lamelar. Novamente, a maior diferença foi detectada para o agente etanol. Estes resultados indicam que o etanol é mais efetivo na supressão da soldagem para tempos de moagem relativamente curtos, ao passo que 0 ciclohexano mostrou-se ineficiente como inibidor da soldagem.

A constatação de que o agente etanol é capaz de produzir significativas alterações microestruturais resultantes de pequenas mudanças na sua quantidade $(0,5 \%$ para 30 minutos de moagem), pode explicar as grandes disparidades encontradas nos resultados de densidade relativa para tempos de moagem relativamente curtos. Tais observações são mais um indício de que a realização de um estudo em uma faixa menos ampliada de variação dos fatores (variáveis) para esse agente em tempos de moagem inferiores a 60 minutos, pode proporcionar um modelo mais adequado para realizar previsões e construir a superfície de resposta na região investigada.

Os resultados encontrados até 0 momento para os quatro ACPs contradizem os obtidos por Shaw et al. (2003), que verificaram uma melhor eficiência do metanol em relação ao ácido esteárico na supressão da soldagem em moagens com 960 minutos para ligas de alumínio. Contudo, as disparidades encontradas podem estar relacionadas com os distintos tempos de processamento das misturas empregados em cada caso. 


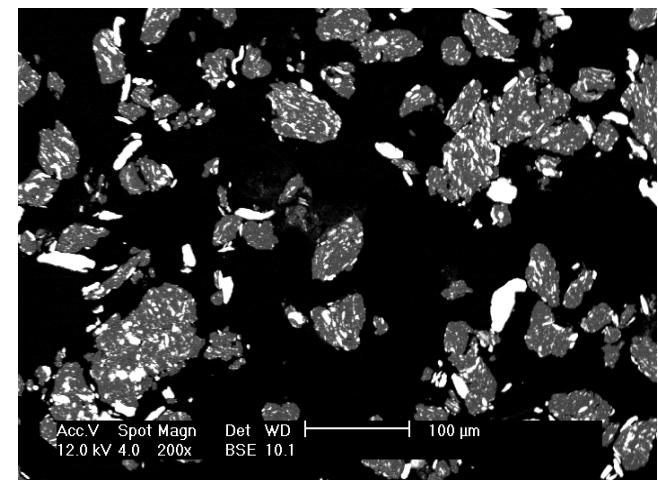

(a) 30 minutos; 0,5\% (95,88\%)

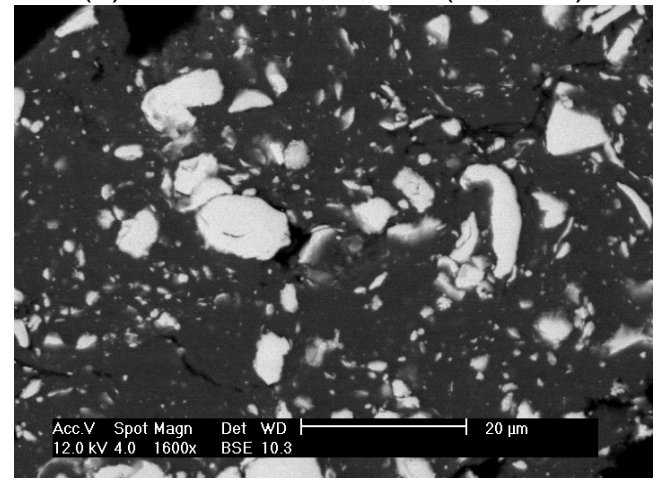

(c) Detalhe da microestrutura em (a)

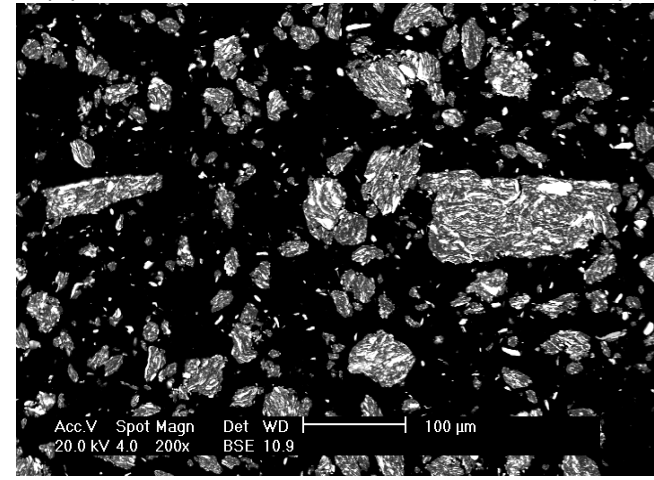

(e) 60 minutos; $1,0 \%(89,41 \%)$

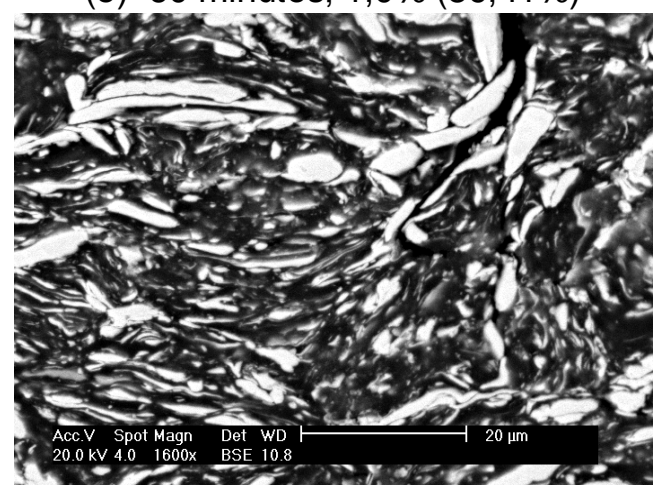

(g) Detalhe da microestrutura em (e)

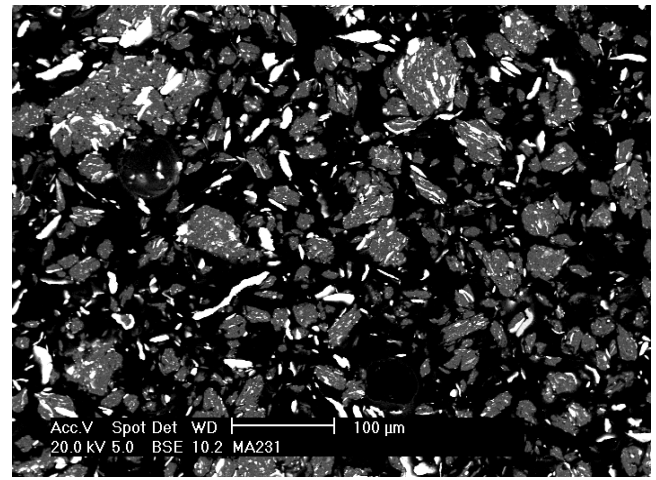

(b) 30 minutos; $1,5 \%(82,94 \%)$

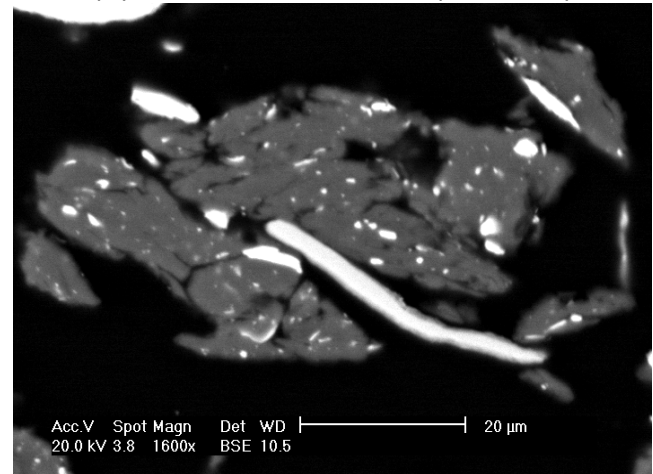

(d) Detalhe da microestrutura em (b)

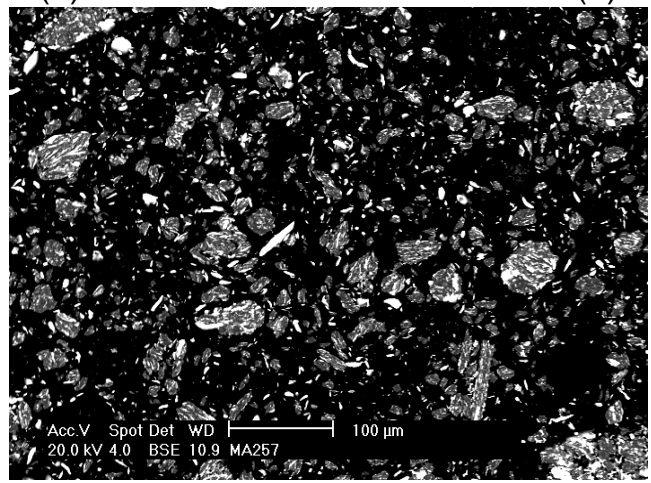

(f) 60 minutos; $1,7 \%(92,62 \%)$

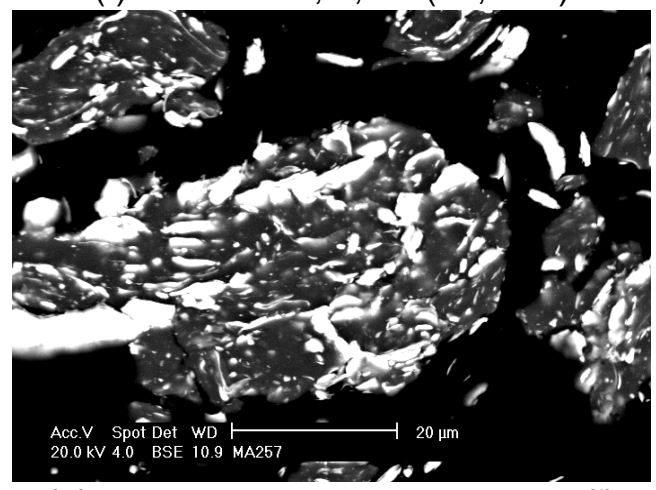

(h) Detalhe da microestrutura em (f)

FIGURA 29 - Micrografias eletrônicas de varredura (elétrons retroespalhados) dos pós moídos com ácido esteárico por 30 e 60 minutos. As quantidades estão indicadas em cada caso. 


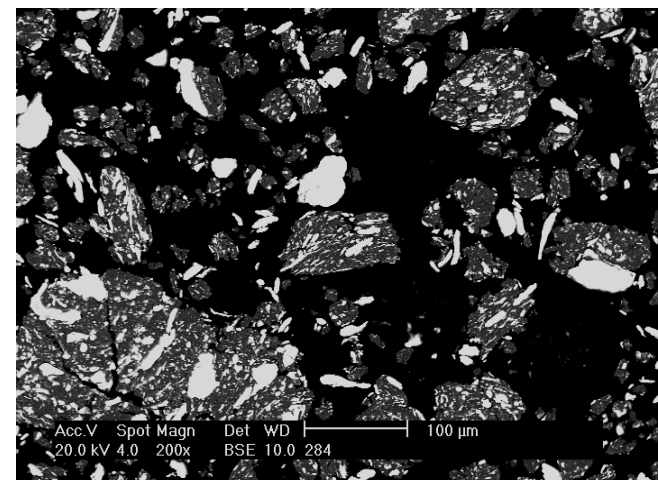

(a) 30 minutos; $0,5 \%(96,05 \%)$

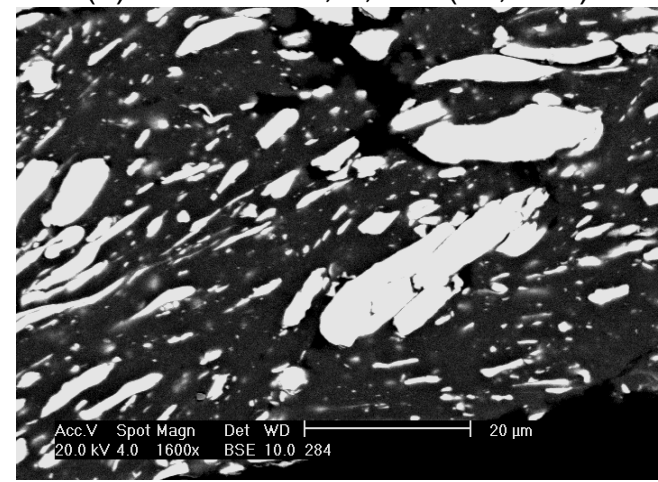

(c) Detalhe da microestrutura em (a)

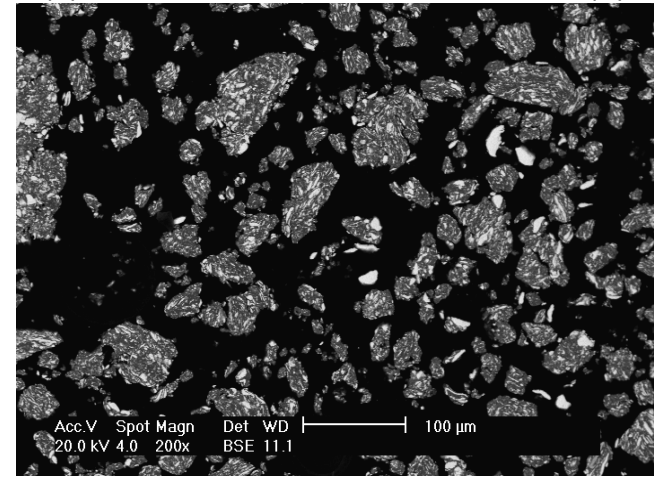

(e) 60 minutos; $1,0 \%(92,12 \%)$

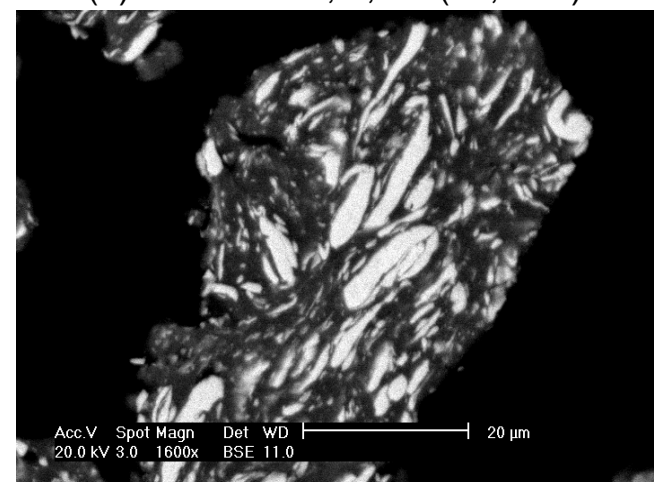

(g) Detalhe da microestrutura em (e)

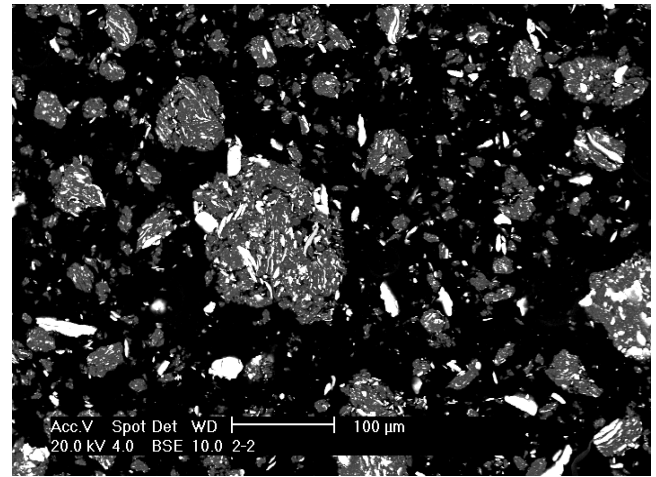

(b) 30 minutos; $1,5 \%(77,68 \%)$

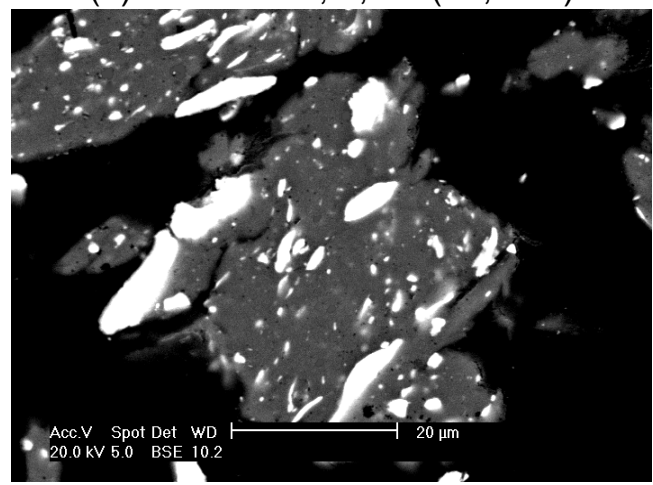

(d) Detalhe da microestrutura em (b)

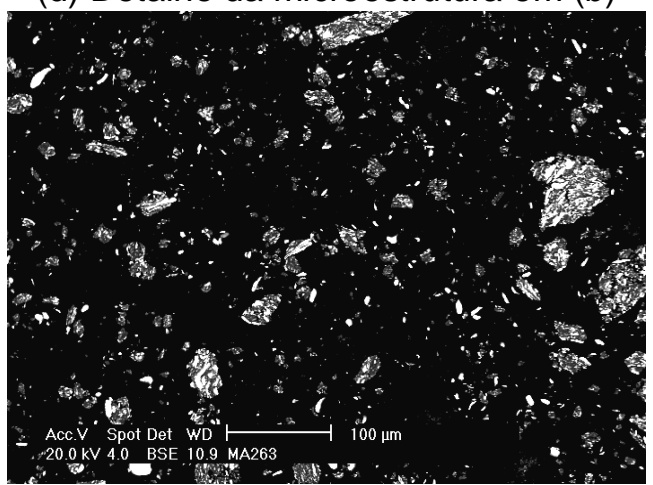

(f) 60 minutos; $1,7 \%(86,43 \%)$

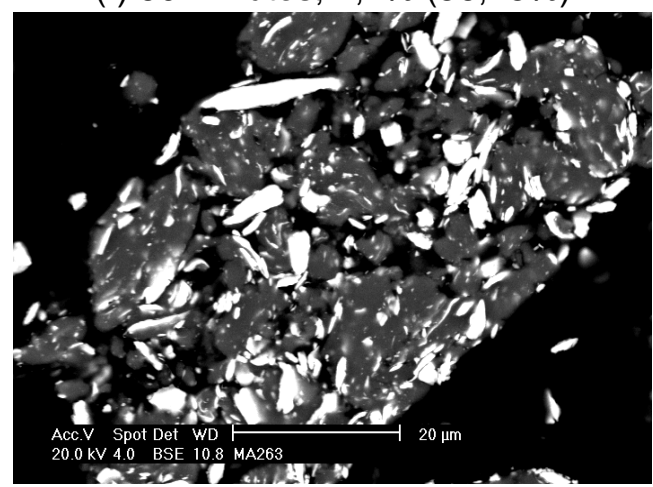

(h) Detalhe da microestrutura em (f)

FIGURA 30 - Micrografias eletrônicas de varredura (elétrons retroespalhados) dos pós moídos com etanol por 30 e 60 minutos. As quantidades estão indicadas em cada caso. 


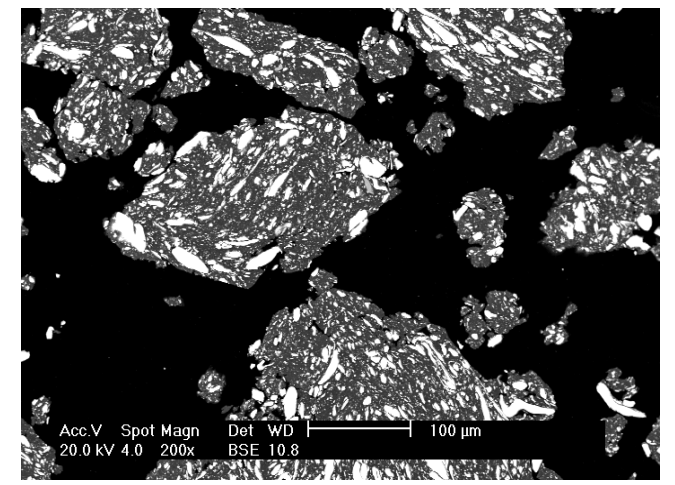

(a) 30 minutos; $0,5 \%(87,24 \%)$

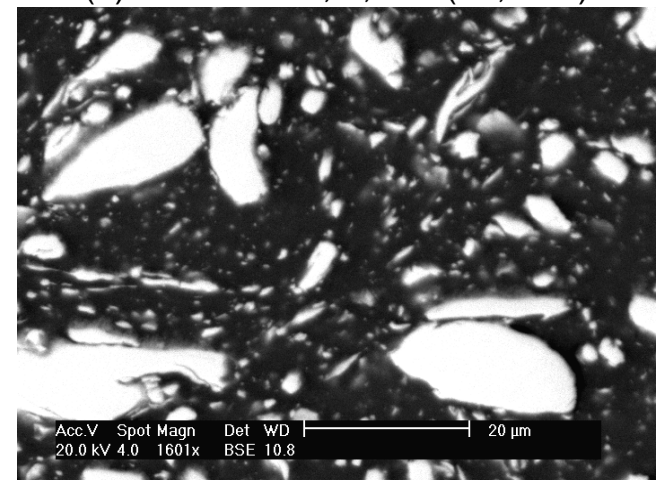

(c) Detalhe da microestrutura em (a)

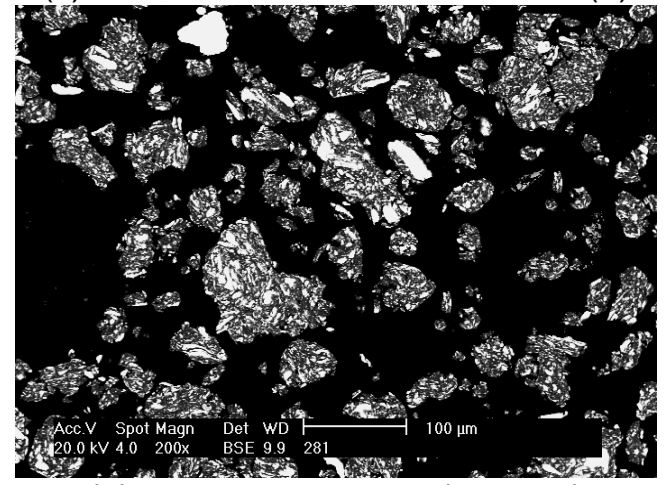

(e) 60 minutos; $1,0 \%(88,85 \%)$

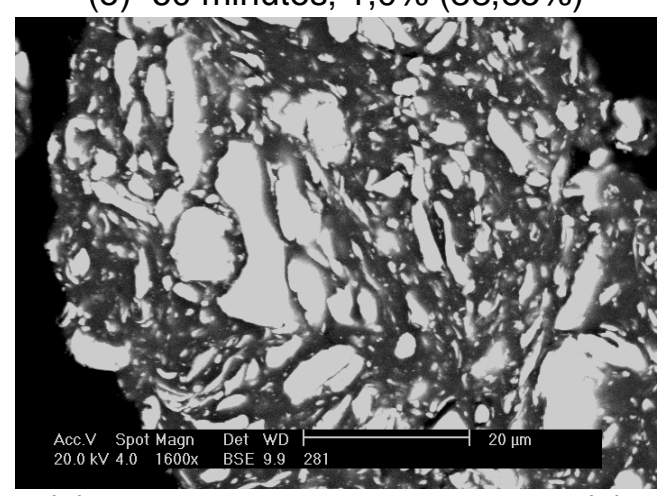

(g) Detalhe da microestrutura em (e)

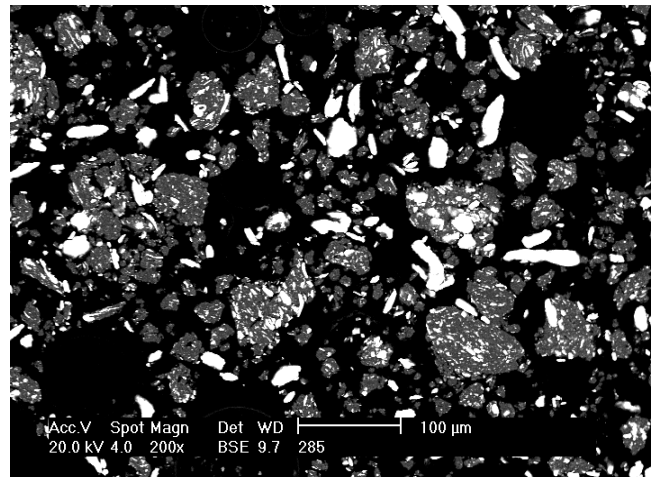

(b) 30 minutos; $1,5 \%(94,88 \%)$

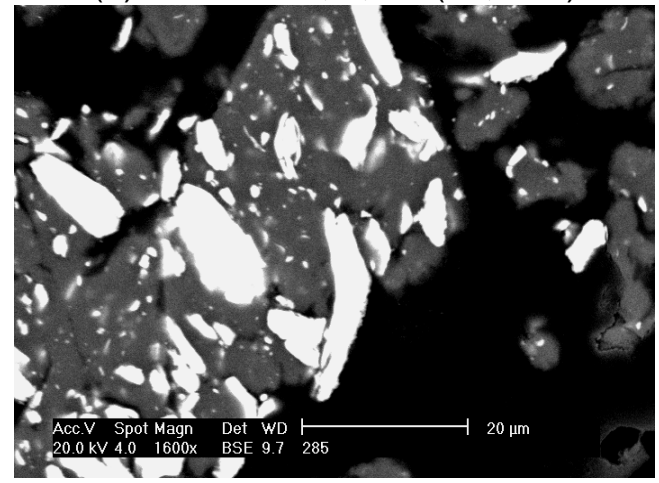

(d) Detalhe da microestrutura em (b)

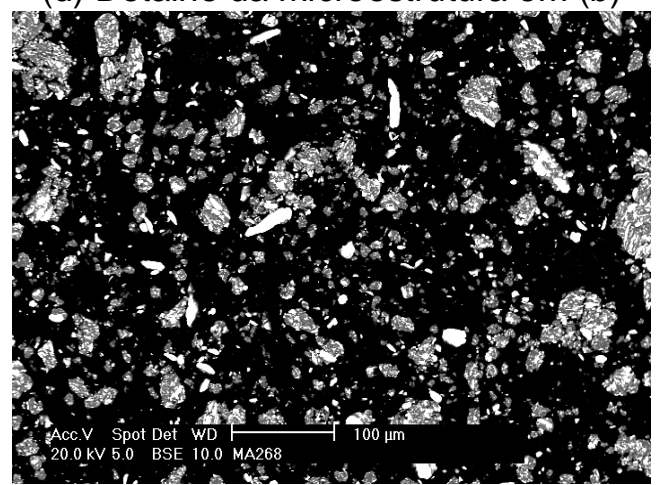

(f) 60 minutos; $1,7 \%(89,00 \%)$

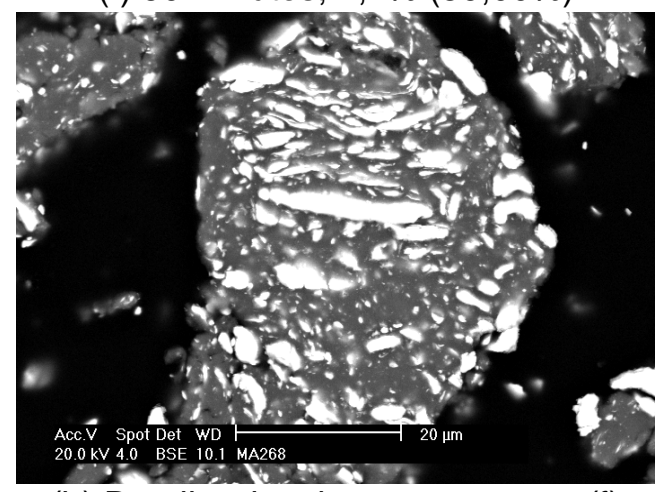

(h) Detalhe da microestrutura em (f)

FIGURA 31 - Micrografias eletrônicas de varredura (elétrons retroespalhados) dos pós moídos com metanol por 30 e 60 minutos. As quantidades estão indicadas em cada caso. 


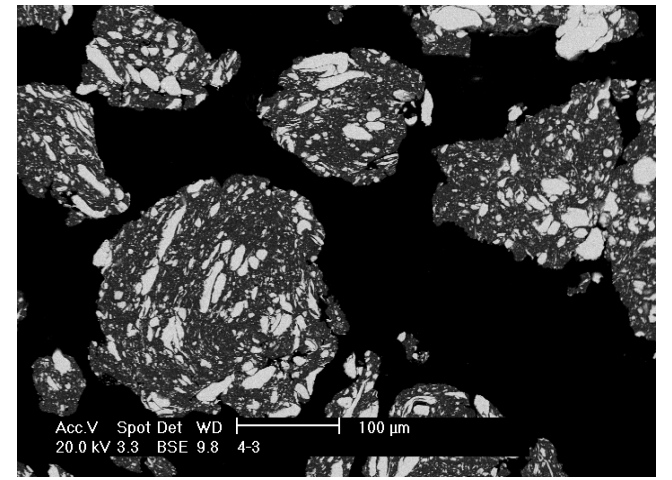

(a) 30 minutos; $0,5 \%(82,70 \%)$

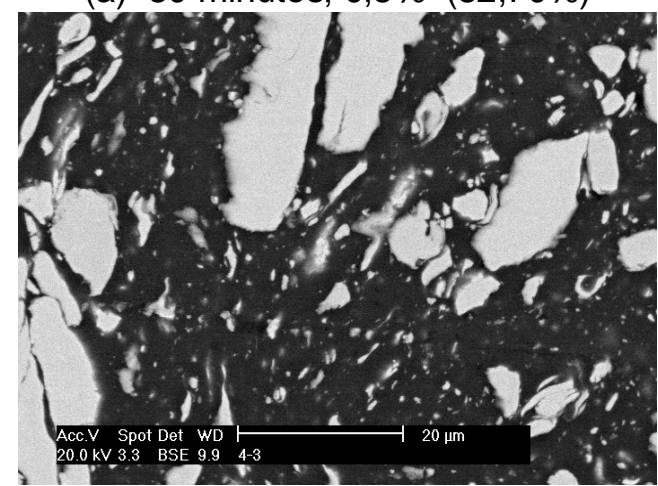

(c) Detalhe da microestrutura em (a)

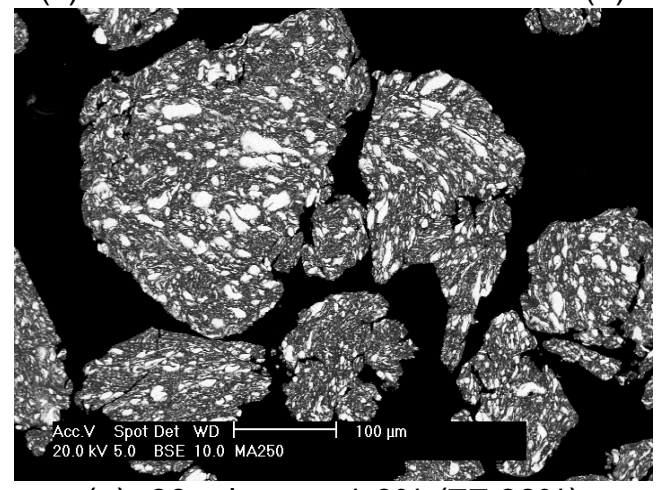

(e) 60 minutos; $1,0 \%(77,36 \%)$

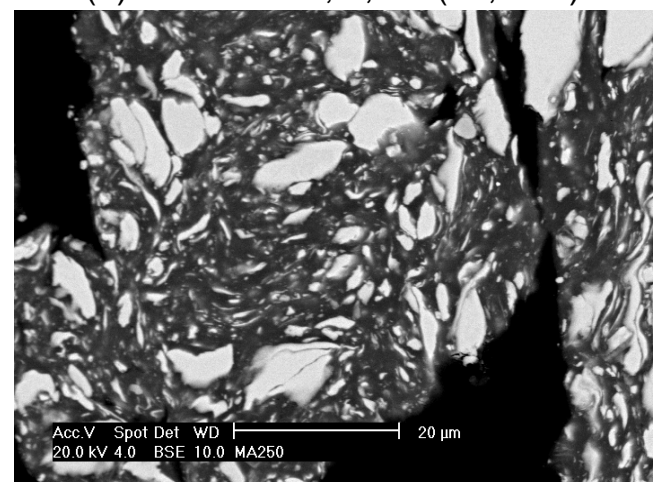

(g) Detalhe da microestrutura em (e)

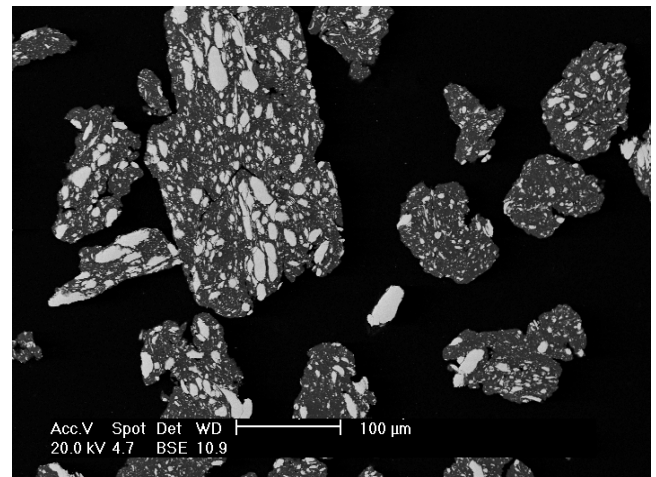

(b) 30 minutos; $1,5 \%(90,96 \%)$

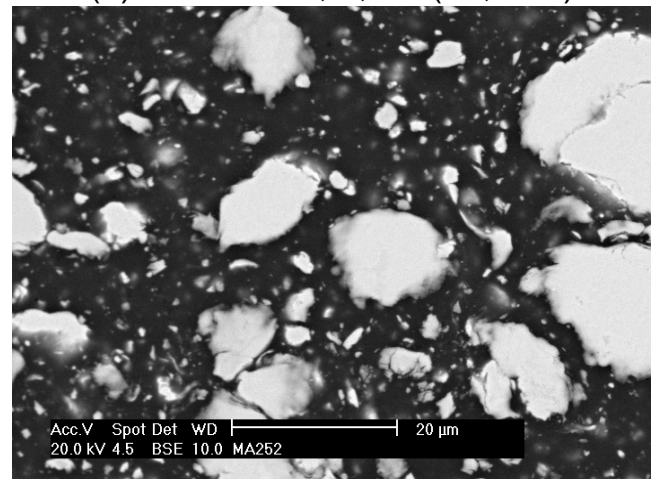

(d) Detalhe da microestrutura em (b)

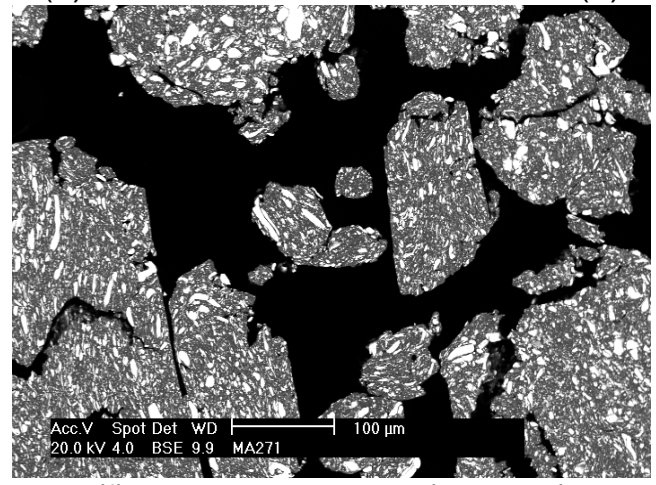

(f) 60 minutos; $1,7 \%(84,01 \%)$

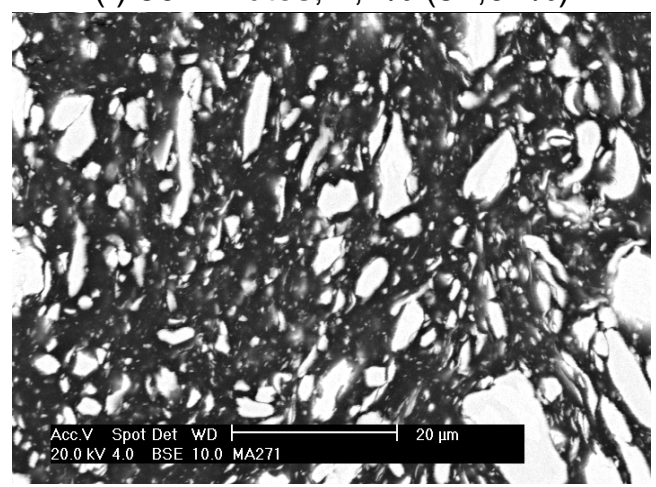

(h) Detalhe da microestrutura em (f)

FIGURA 32 - Micrografias eletrônicas de varredura (elétrons retroespalhados) dos pós moídos com ciclohexano por 30 e 60 minutos. As quantidades estão indicadas em cada caso. 
É importante tecer algumas considerações com relação aos pós moídos por 18 minutos com 1,0\% de cada ACP. Esta condição revelou-se benéfica para as densidades relativas obtidas com o uso dos agentes metanol e ciclohexano, ao passo que para o ácido esteárico e, sobretudo, para o etanol, resultou em densidades bem inferiores ao esperado. Na FIG. 33 são apresentadas as micrografias das misturas moídas nessa condição.

A supressão mais pronunciada do evento de soldagem nas misturas com ácido esteárico e etanol (para 18 minutos de moagem com 1,0\% de ACP) originou partículas achatadas com uma grande quantidade de partículas de nióbio não associadas com o alumínio, correspondente aos primeiros estágios da ativação mecânica. Aliado a este fato, a análise visual permite observar uma maior dispersão no tamanho das partículas na moagem com etanol. Nos pós moídos com metanol e, notadamente, com ciclohexano, observou-se a presença de partículas de alumínio ligeiramente arredondadas contendo partículas de nióbio incrustadas. Tais microestruturas remetem, respectivamente, às obtidas com a adição de $0,5 \%$ de ácido esteárico e 1,5\% de metanol para 30 minutos de moagem, e evidenciam a menor eficiência dos agentes metanol e ciclohexano na atuação como lubrificantes.

Com o intuito de tornar mais objetiva a análise das diferenças encontradas com relação à quantidade de partículas isoladas de nióbio nas misturas moídas com 30 e 60 minutos de moagem (condições que resultaram em maiores densidades relativas), foi realizada uma quantificação da fração volumétrica dessas partículas por meio da análise de imagem. Tal análise foi realizada com o auxílio do software Quantikov (Pinto, 1996), após tratamento manual das imagens no programa Adobe Photoshop ${ }^{\circledR}$ CS3. Esse tratamento preliminar foi necessário em razão da dificuldade em discriminar, nos programas de análises de imagens, 0 nióbio como partícula isolada, do nióbio presente nos agregados. O software Quantikov mensura as fases em branco (nível de cinza correspondente a 255), sendo necessário converter, em preto e branco, as imagens coloridas. As análises foram realizadas em 10 regiões distintas para cada condição, em micrografias obtidas em aumentos de $100 \times$. Na FIG. 34 é apresentada a sequência do procedimento adotado. As escalas das micrografias foram suprimidas visando alcançar uma maior área efetiva da imagem. 
Dispersão dos agregados

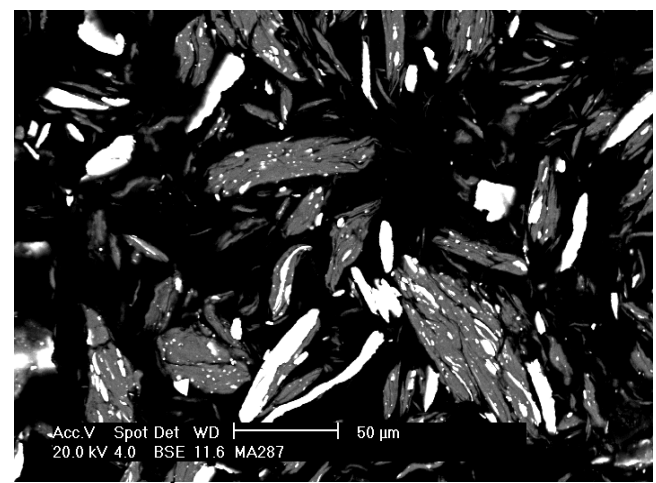

(a) Ácido esteárico $(78,19 \%)$

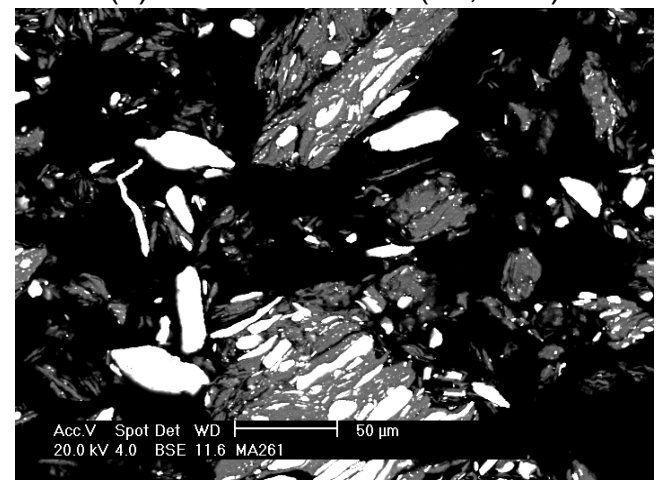

(c) Etanol $(69,76 \%)$

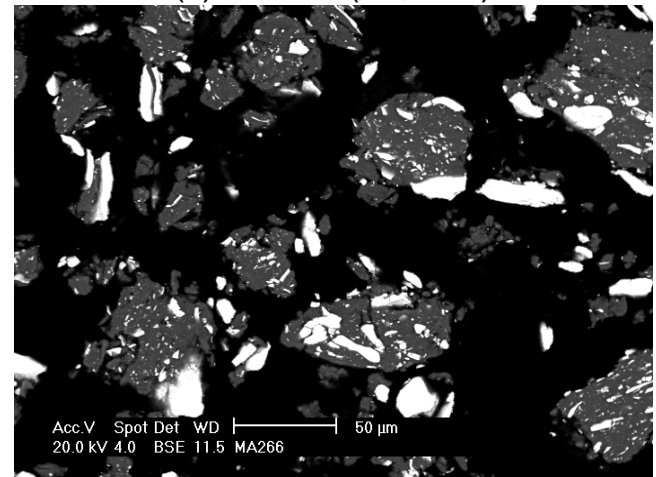

(e) Metanol $(92,00 \%)$

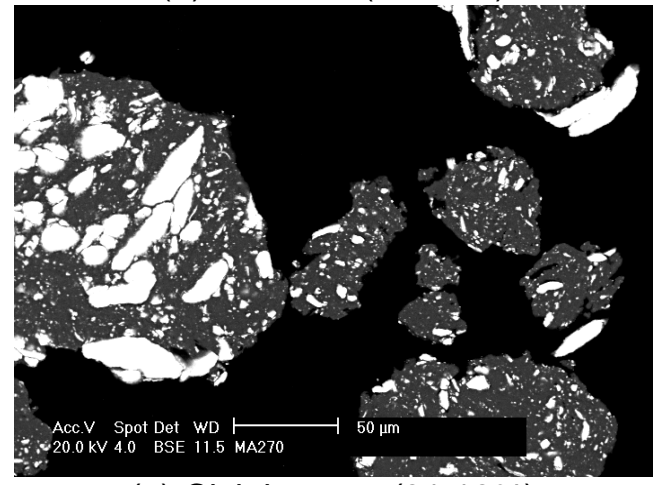

(g) Ciclohexano $(91,18 \%)$
Detalhe da microestrutura

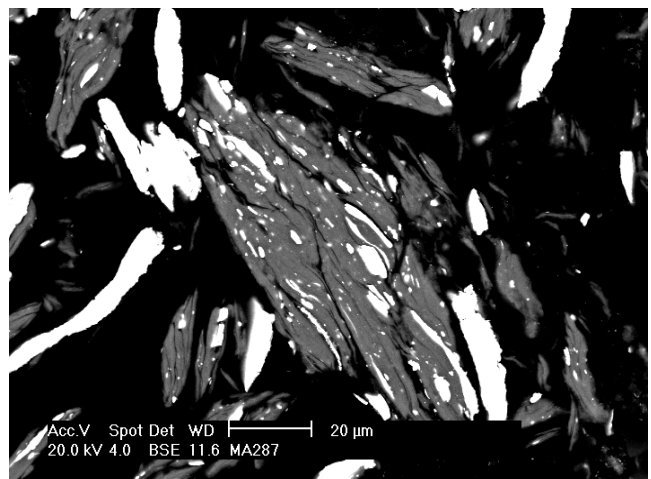

(b) Ácido esteárico $(78,19 \%)$

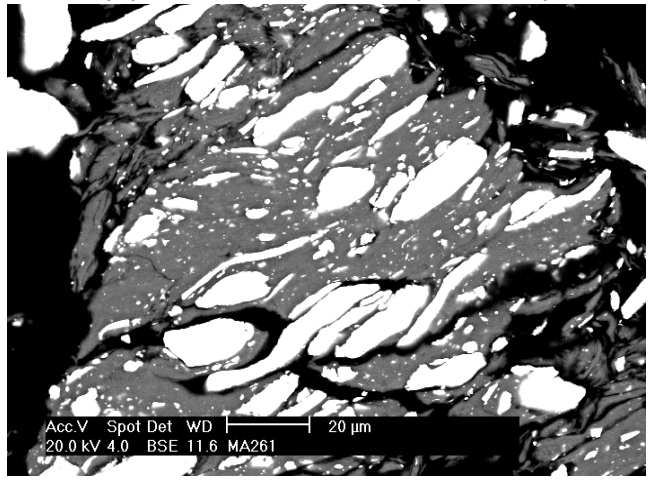

(d) Etanol $(69,76 \%)$

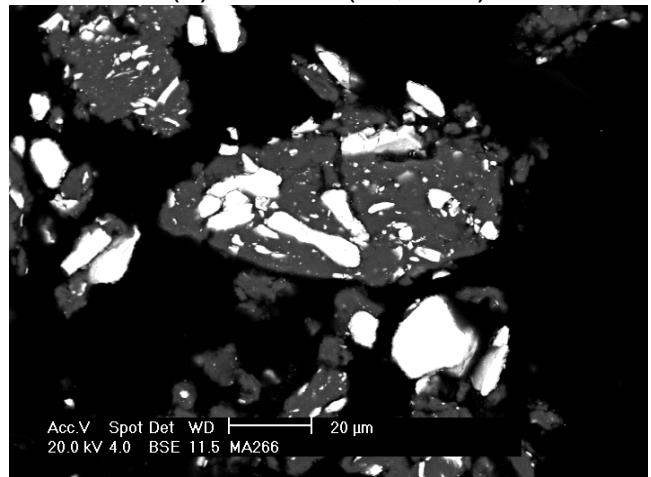

(f) Metanol $(92,00 \%)$

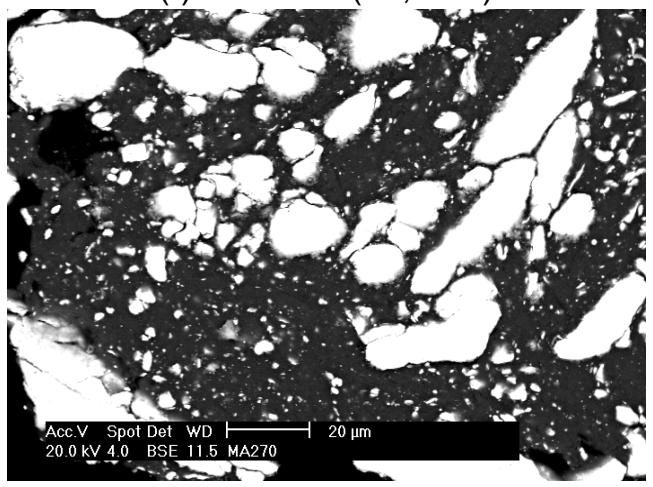

(h) Ciclohexano $(91,18 \%)$

FIGURA 33 - Micrografias eletrônicas de varredura (elétrons retroespalhados) dos pós moídos por 18 minutos com 1,0\% de cada ACP. 

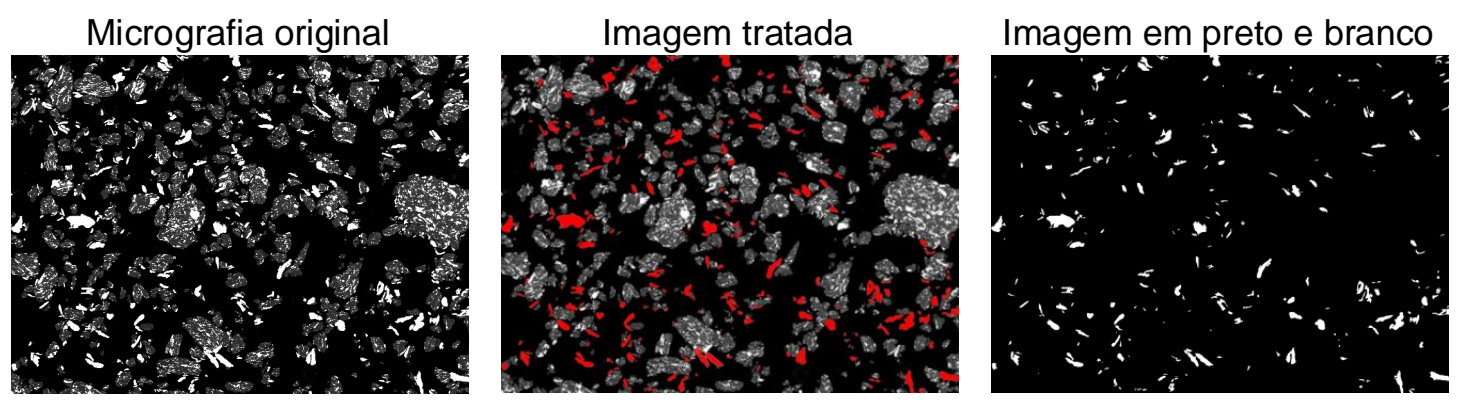

Ácido esteárico
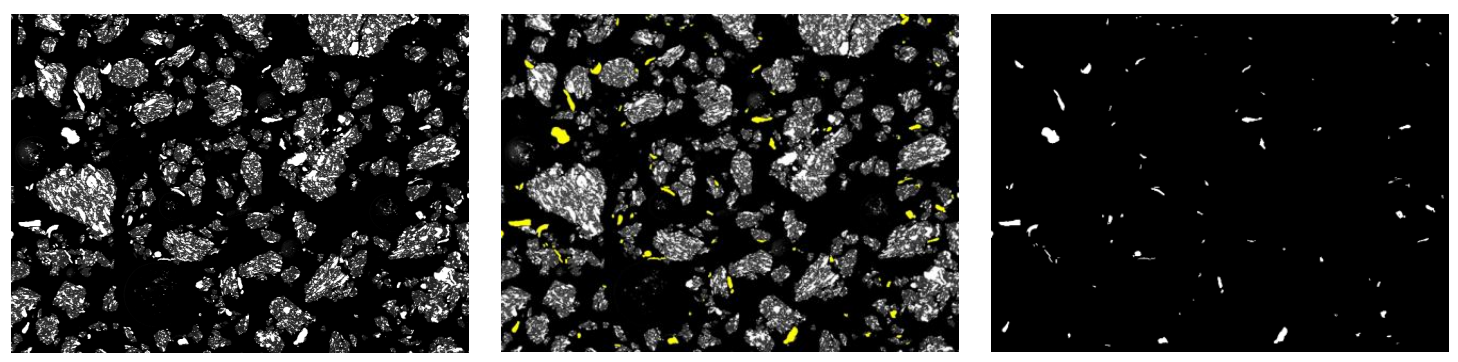

\section{Etanol}
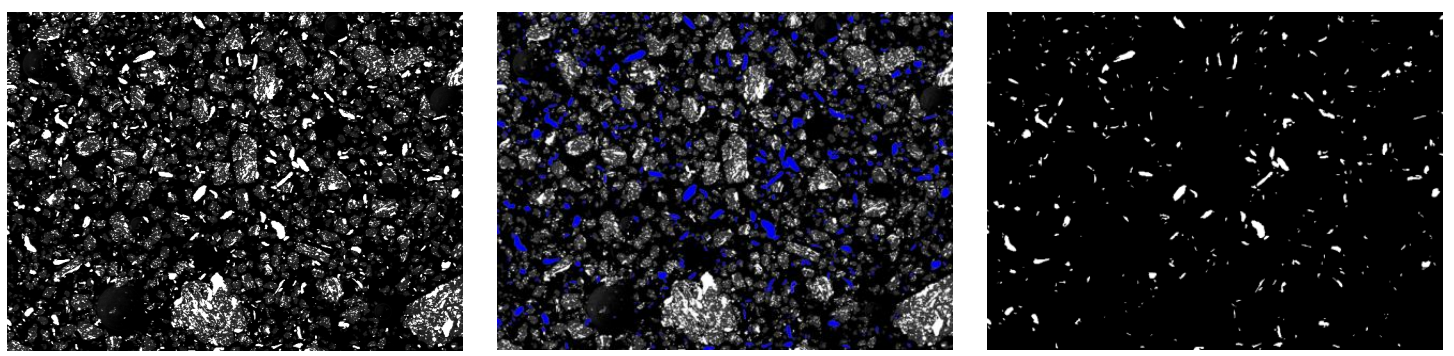

Metanol
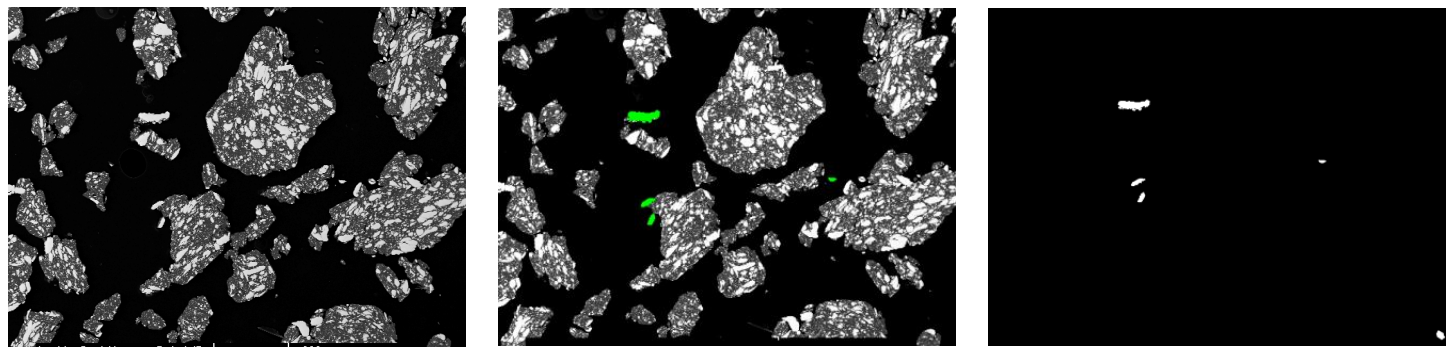

Ciclohexano

FIGURA 34 - Sequência do procedimento adotado nas análises de imagens.

$\mathrm{Na}$ TAB. 24 são apresentados os resultados obtidos nas análises de imagens das misturas moídas com os quatro ACPs na condição padrão e com 30 minutos de moagem (0,5\% para o ácido esteárico e etanol; 1,5\% para o metanol e ciclohexano). 
TABELA 24 - Análises de imagens das misturas moídas por 30 e 60 minutos.

\begin{tabular}{|c|c|c|c|c|}
\hline \multirow{2}{*}{ ACP } & $\begin{array}{c}\text { Tempo de } \\
\text { moagem } \\
\text { (minutos) }\end{array}$ & $\begin{array}{c}\text { Quantidade } \\
\text { de ACP } \\
\text { (\%) }\end{array}$ & $\begin{array}{c}\text { Fvol média de }_{\text {partículas isoladas }} \\
\text { de nióbio (\%) }\end{array}$ & $\begin{array}{c}\text { Desvio } \\
\text { padrão das } \\
\text { medidas }\end{array}$ \\
\hline \multirow{2}{*}{ Ácido esteárico } & 30 & 0,5 & 9,01 & $\pm 0,84$ \\
\cline { 2 - 5 } & 60 & 1,0 & 1,21 & $\pm 0,12$ \\
\hline \multirow{2}{*}{ Etanol } & 30 & 0,5 & 8,84 & $\pm 0,62$ \\
\cline { 2 - 5 } & 60 & 1,0 & 1,64 & $\pm 0,14$ \\
\hline \multirow{2}{*}{ Metanol } & 30 & 1,5 & 9,72 & $\pm 0,92$ \\
\cline { 2 - 5 } & 60 & 1,0 & 1,25 & $\pm 0,13$ \\
\hline \multirow{2}{*}{ Ciclohexano } & 30 & 1,5 & 0,45 & $\pm 0,07$ \\
\cline { 2 - 5 } & 60 & 1,0 & 0,25 & $\pm 0,05$ \\
\hline
\end{tabular}

$\mathrm{F}_{\mathrm{vol} .}=$ fração volumétrica

Os valores de fração volumétrica $\left(F_{\text {vol }}\right)$ média apresentados foram obtidos em relação à fração volumétrica de todas as partículas existentes em cada micrografia.

Os resultados apresentados na TAB. 24 estão condizentes com as análises visuais das micrografias obtidas nessas condições. Para 60 minutos de moagem com $1,0 \%$ de ACP, o etanol atuou de forma mais preponderante na supressão do evento de soldagem, evidenciada por uma quantidade de partículas isoladas de nióbio ligeiramente superior em comparação com os outros agentes. Por outro lado, a adição de 1,0\% de ciclohexano mostrou-se ineficiente para esse tempo de moagem, produzindo mais de $99 \%$ de partículas grosseiras na forma de agregados de nióbio e alumínio.

Para 30 minutos de moagem com os agentes ácido esteárico, etanol e metanol houve praticamente a mesma quantidade de partículas isoladas de nióbio, considerando os desvios padrão obtidos nas medidas. Entretanto, vale ressaltar que nesse tempo de moagem, as misturas de Nb75Al foram moídas com apenas $0,5 \%$ de ácido esteárico e etanol contra 1,5\% de metanol. Nesta condição, os valores consideravelmente elevados dos desvios padrão sugerem a necessidade de realizar análises de imagens em um maior número de regiões 
distintas com o intuito de classificar os agentes segundo a fração volumétrica de partículas soltas. Os ACPs ácido esteárico e etanol, assim como observado nas micrografias, acarretaram em um maior atraso na cinética de formação dos agregados. Mais uma vez, a adição de $1,5 \%$ de ciclohexano não foi suficiente para evitar a soldagem.

Os resultados obtidos até o momento sugerem um compromisso entre a presença de partículas isoladas de nióbio com a microestrutura dos agregados, capaz de promover alterações significativas nas densidades das pastilhas de $\mathrm{NbAl}_{3}$. É provável que exista um estágio durante o processo de ativação mecânica, antes e após o qual, as densidades começam a diminuir. Tal fato pôde ser observado notadamente para os agentes ácido esteárico e etanol. A presença de lamelas altamente refinadas revelou-se prejudicial à densificação, conforme observado nas micrografias obtidas com as misturas moídas por 90 minutos, (FIG. 28). Por outro lado, uma microestrutura correspondente aos primeiros estágios da ativação mecânica (FIG. 33) também gerou pastilhas com baixas densidades relativas (no caso do etanol a densidade foi inferior às obtidas com 90 minutos de moagem). Nesse sentido, a presença de certa quantidade de partículas isoladas de nióbio (por volta de 9\%, segundo os dados da TAB. 24), juntamente com agregados de tamanhos reduzidos constituídos por partículas incrustadas, ou lamelas pouco refinadas, de nióbio no alumínio, parecem ser um fator importante na densificação das pastilhas de $\mathrm{NbAl}_{3}$, conforme indicam as microestruturas obtidas nas condições que produziram as maiores densidades relativas, especialmente para os agentes ácido esteárico e etanol (FIG. 29 e 30).

\subsubsection{Difração de raios $\mathrm{X}$ das misturas mecanicamente ativadas}

As misturas moídas por 30 minutos com 0,5\% de ácido esteárico e etanol, e com $1,5 \%$ de metanol e ciclohexano (condição que gerou maiores densidades relativas), 60 minutos com 1,0\% de cada ACP (condição padrão) e 90 minutos com $0,5 \%$ de cada ACP (condição que gerou menores densidades relativas), foram analisadas qualitativamente por difração de raios $X$. Essa análise teve como intuito verificar a formação de fases de nióbio e alumínio previamente à 
reação de combustão. Os difratogramas destas misturas são apresentados nas FIG. 35 a 37.

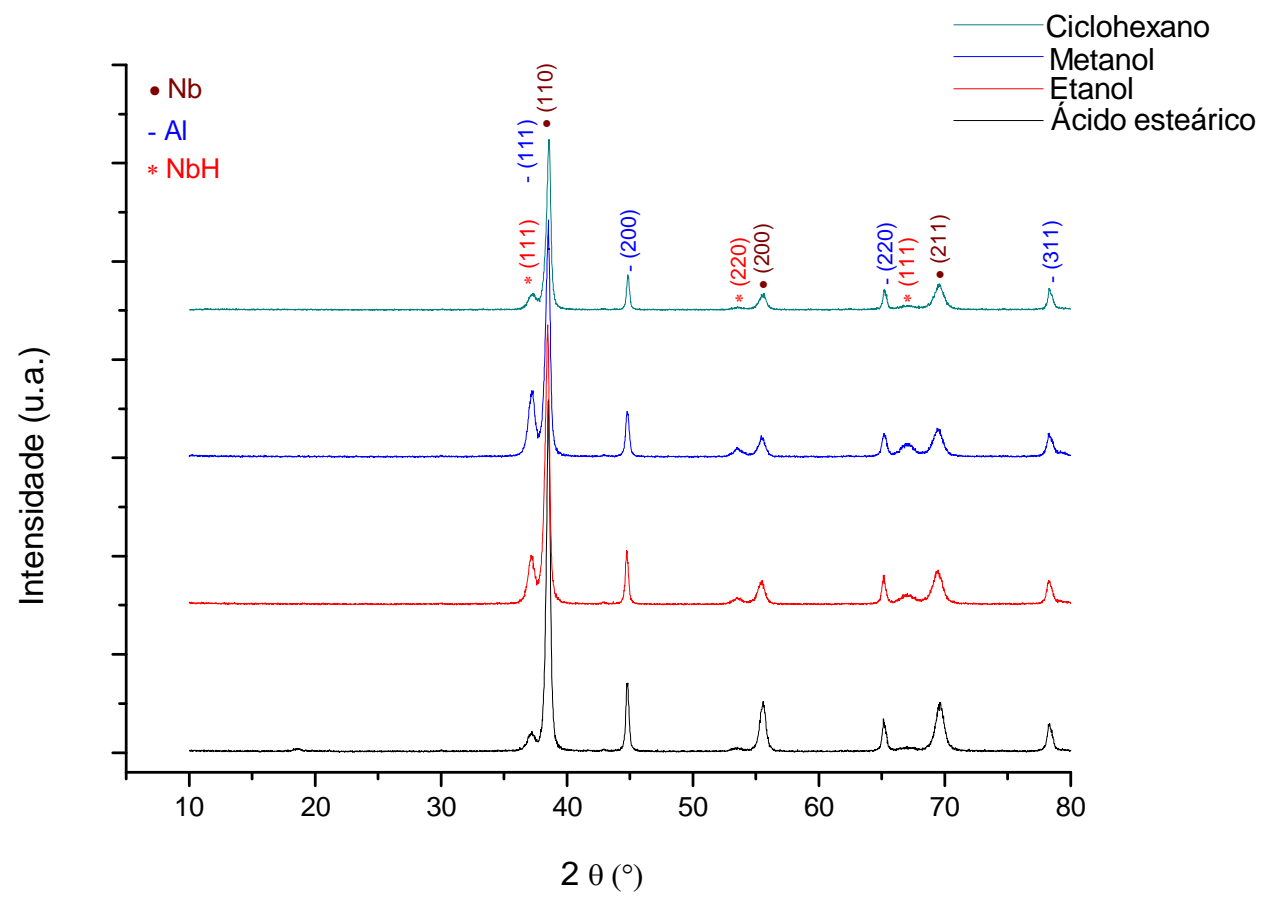

FIGURA 35 - Difratogramas de raios, $X$ das misturas moídas por 30 minutos com os diferentes ACPs. Ácido esteárico e etanol (0,5\%); metanol e ciclohexano $(1,5 \%)$.

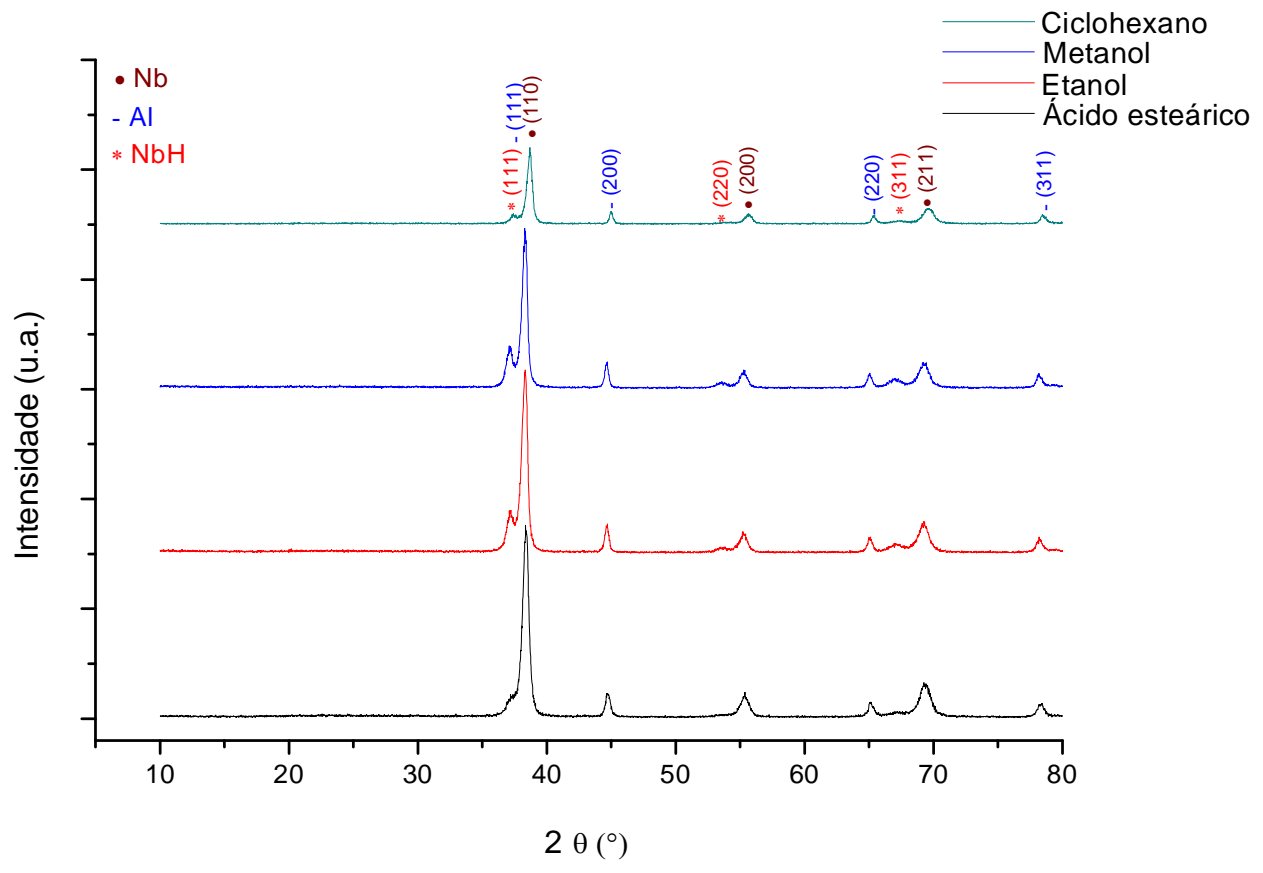

FIGURA 36 - Difratogramas de raios $X$ das misturas moídas por 60 minutos com $1,0 \%$ dos diferentes ACPs. 


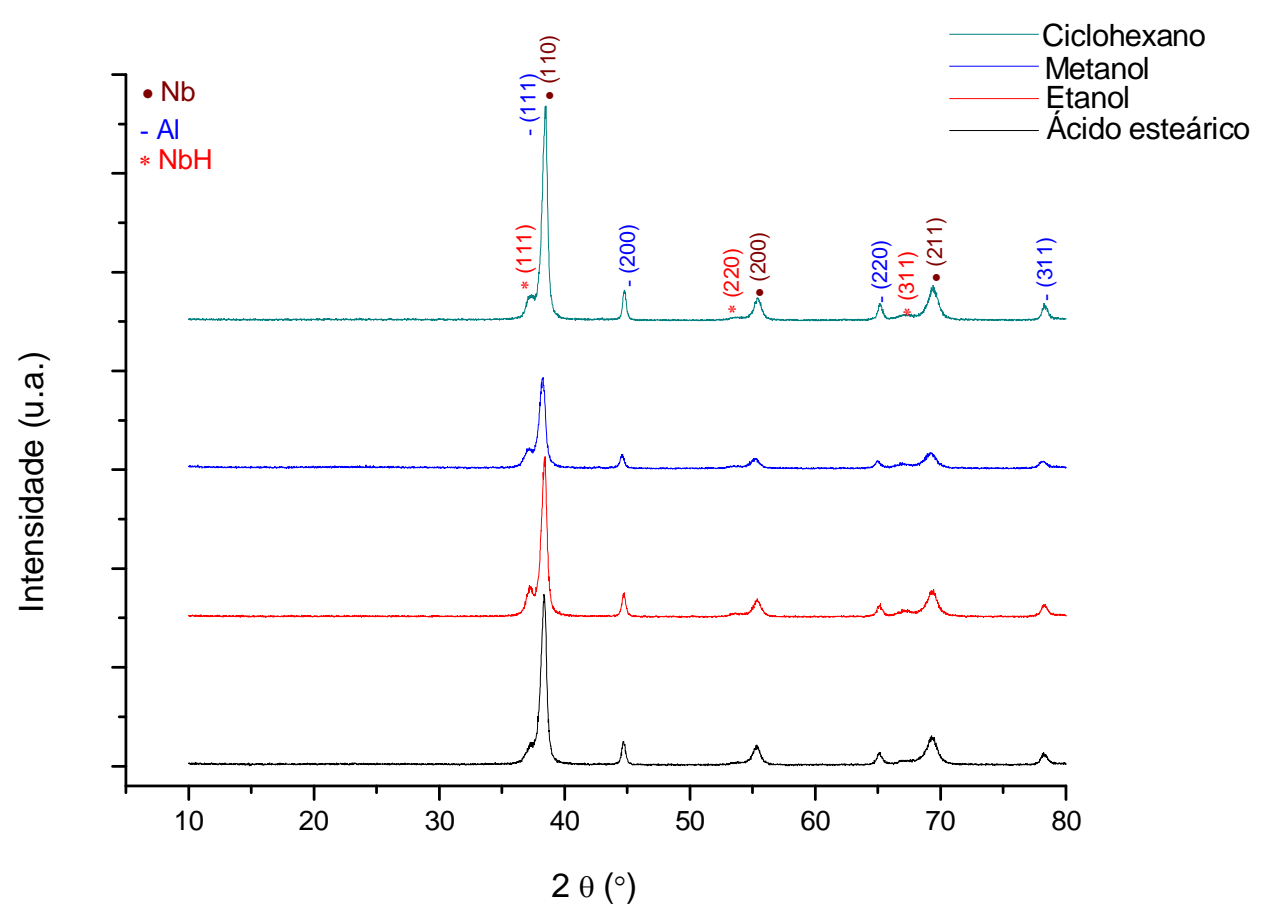

FIGURA 37 - Difratogramas de raios $\mathrm{X}$ das misturas moídas por 90 minutos com $0,5 \%$ dos diferentes ACPs.

A formação do composto intermetálico $\mathrm{NbAl}_{3}$ durante a moagem com alta energia não foi detectada em nenhuma das condições apresentadas nos difratogramas (FIG. 35 a 37). É possível apenas constatar a presença dos picos relativos às estruturas cristalinas cúbicas de corpo centrado e face centrada, respectivamente, dos elementos nióbio e alumínio. Acrescido a estes picos, observou-se também a presença dos picos referentes à fase hidreto de nióbio $(\mathrm{NbH})$. Tal fase não foi revelada no difratograma de raios $\mathrm{X}$ do pó de nióbio (FIG. 38). A explicação mais provável para a formação de tal hidreto é a de que este seja proveniente de uma absorção de hidrogênio (possivelmente fornecido por uma decomposição parcial ou total dos agentes) pelo nióbio durante a moagem com alta energia. O comportamento térmico das pastilhas compactadas (avaliado mediante a pressão do sistema durante o ciclo de aquecimento para a reação por combustão) também sugere a presença de $\mathrm{NbH}$ nas misturas moídas. Por volta de $300^{\circ} \mathrm{C}$ ocorre um aumento progressivo da pressão do sistema, provocada por uma liberação de gases, a qual volta a diminuir a partir de $350^{\circ} \mathrm{C}$. Nesse intervalo de temperatura, Portnoy et al. (2000) observaram a liberação de hidrogênio 
durante tratamento térmico realizado após 20 minutos de moagem com alta energia de pós de nióbio em atmosfera de hidrogênio, sob pressão de 170 torr $(\sim 23 \mathrm{kPa})$.

Na FIG. 39 são apresentados os difratogramas das misturas moídas por 18, 60 e 102 minutos com 1,0\% de ácido esteárico. Com apenas 18 minutos de moagem já é possível observar a presença dos picos relativos ao $\mathrm{NbH}$, sendo mais um indício de que uma possível decomposição do ácido esteárico ocorre logo nos primeiros estágios da ativação mecânica.

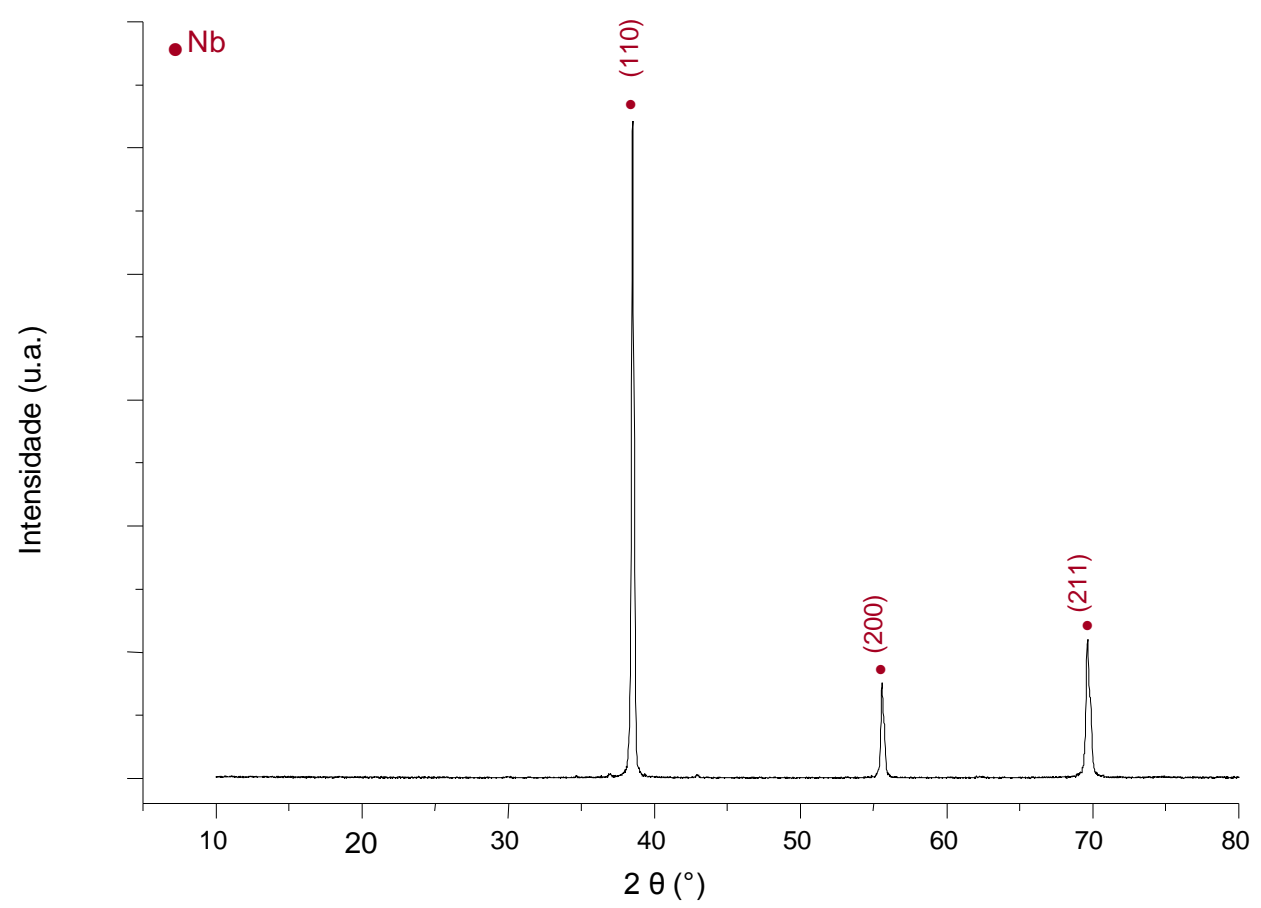

FIGURA 38 - Difratograma de raios $\mathrm{X}$ do pó de nióbio. 


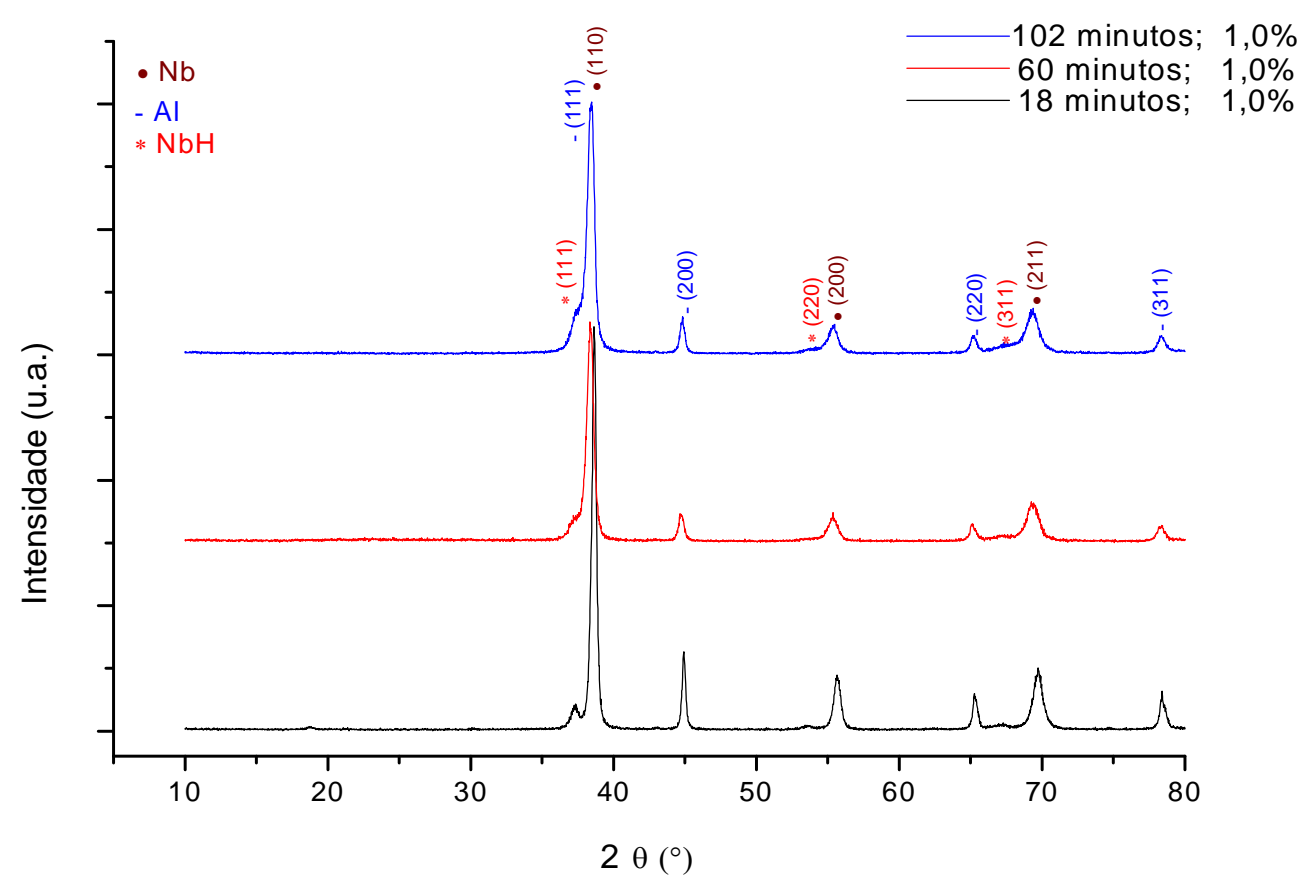

FIGURA 39 - Difratogramas de raios X das misturas moídas por 18, 60 e 102 minutos com $1,0 \%$ de ácido esteárico.

\subsubsection{Espectroscopia no infravermelho das misturas moídas}

Com o propósito de alcançar um melhor entendimento sobre o processo de atuação dos diferentes ACPs com os pós de nióbio e alumínio durante a moagem com alta energia, foram obtidos espectros na região do infravermelho médio para as misturas moídas por 30 minutos com 1,5\% de ácido esteárico e 18 minutos com $1,0 \%$ dos agentes etanol e metanol.

As condições de moagem empregadas foram escolhidas com base na resolução dos espectros, os quais apresentaram baixa relação sinal-ruído com o aumento do tempo de moagem. Os espectros relativos ao ACP ciclohexano não foram apresentados, uma vez que o nível de ruído obtido nessas amostras foi muito elevado, dificultando a interpretação da análise. Com base nos resultados obtidos, foi possível sugerir um mecanismo de interação dos agentes com os pós de Nb75Al para tempos de moagem iguais e inferiores a 30 minutos.

Na FIG. 40 são apresentados os espectros no infravermelho médio obtidos para o ácido esteárico puro e para a mistura moída com $1,5 \%$ deste agente. 0 
intervalo de número de onda analisado no espectro da mistura moída compreendeu 2400 a $650 \mathrm{~cm}^{-1}$, em razão da baixa relação sinal-ruído para números de onda inferiores a $2400 \mathrm{~cm}^{-1}$. As principais vibrações características da molécula do ácido esteárico estão indicadas na figura.

Após o processo de moagem por 30 minutos, ainda é possível distinguir a principal banda de absorção no infravermelho para o ácido esteárico correspondente à vibração de estiramento do grupo carbonila $(\mathrm{C}=\mathrm{O})$, que ocorre por volta de $1700 \mathrm{~cm}^{-1}$. Tal constatação indica que o ácido não se decompôs durante a moagem, ou que ocorreu apenas uma decomposição parcial. Lembrando que a molécula de ácido esteárico consiste em uma cadeia linear alifática com uma terminação polar $(\mathrm{COOH})$, uma possível forma de atuação do ACP com os pós é ilustrada no esquema a seguir.

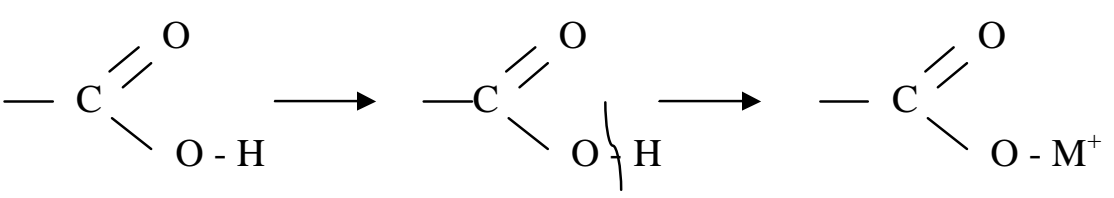

onde $\mathrm{M}^{+}$indica a ligação do oxigênio do ACP com a superfície dos metais.

O esquema apresentado sugere que, durante o processo de moagem, ocorre a quebra da ligação $\mathrm{O}-\mathrm{H}$, liberando hidrogênio. Deste modo, a adsorção do ácido ocorre a partir do oxigênio que se liga à superfície dos pós metálicos, em especial do alumínio, em razão de sua maior afinidade com o oxigênio em relação ao nióbio. 

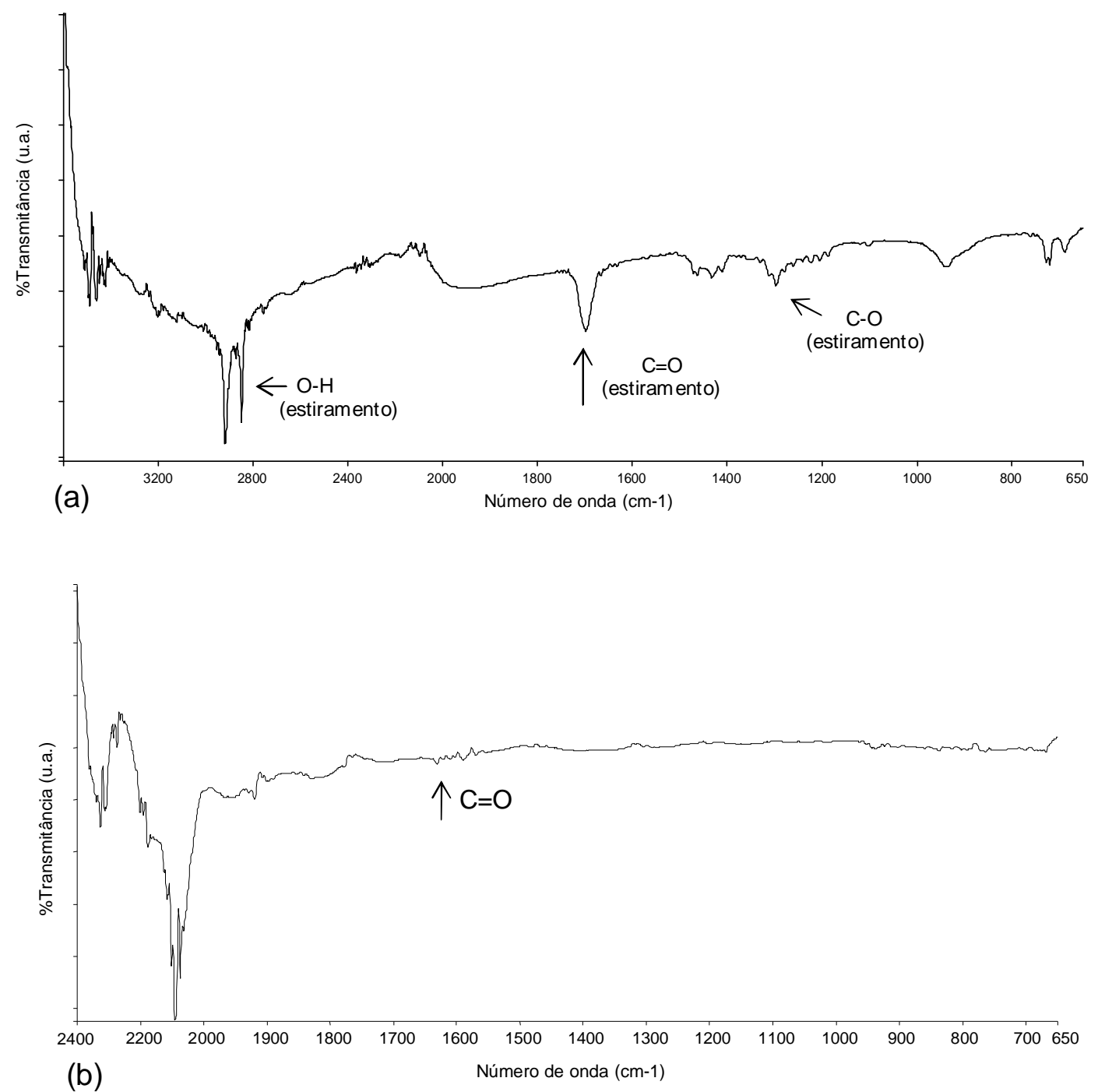

FIGURA 40 - Espectros no infravermelho médio. (a) ácido esteárico; (b) pós moídos por 30 minutos com $1,5 \%$ de ácido esteárico.

Nas FIG. 41 e 42 são apresentados os espectros no infravermelho médio para os agentes etanol (FIG. 41a) e metanol (FIG. 42a), ambos misturados com alumínio antes da moagem com alta energia, e para as misturas moídas com esses agentes (FIG. 41b e 42b). Nos espectros apresentados após 18 minutos de moagem, é possível distinguir a principal banda característica da ligação O-H presente nos álcoois, que ocorre para números de onda entre 3600 e $3200 \mathrm{~cm}^{-1}$. Embora tal banda também possa sugerir a presença de água adsorvida na superfície dos pós, a ligeira semelhança apresentada pelos espectros das 
misturas com etanol, antes e após moagem com alta energia, na região compreendendo o intervalo de número de onda de 1400 a $1000 \mathrm{~cm}^{-1}$, indica a possibilidade da existência deste ACP na forma livre (não decomposta) nos pós moídos por 18 minutos.

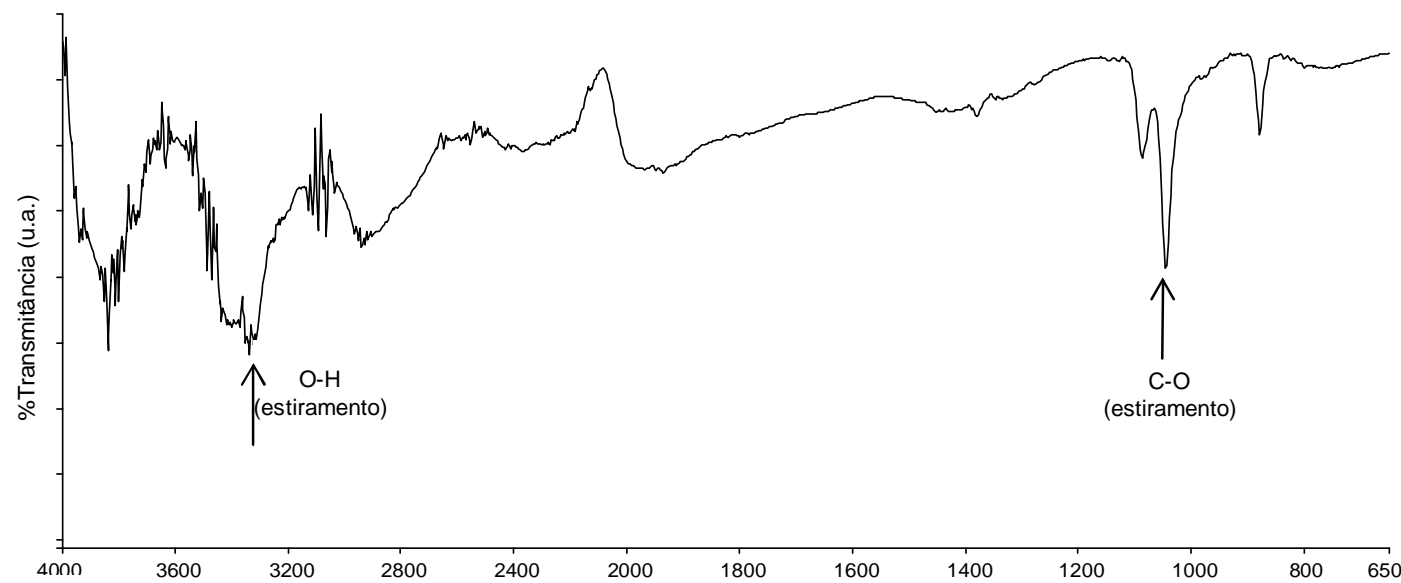

(a)

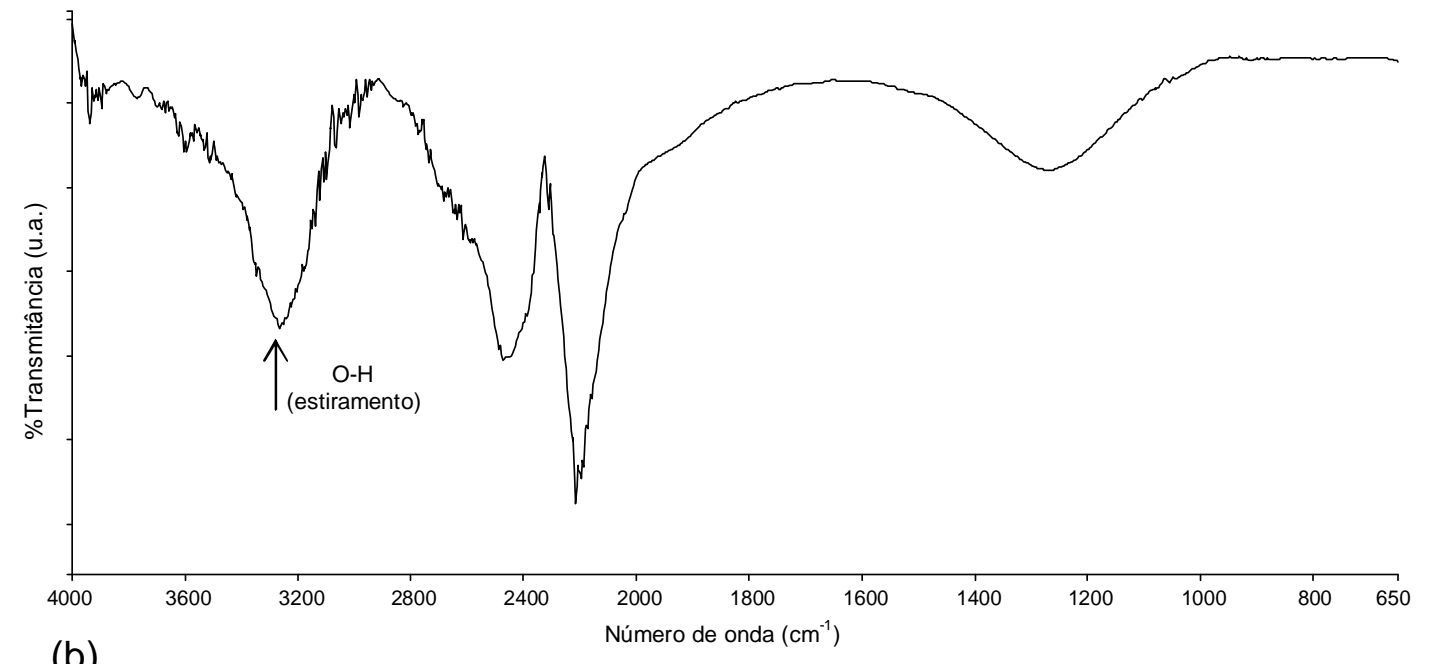

(b)

FIGURA 41 - Espectros no infravermelho médio. (a) etanol; (b) pós moídos por 18 minutos com $1,0 \%$ de etanol. 


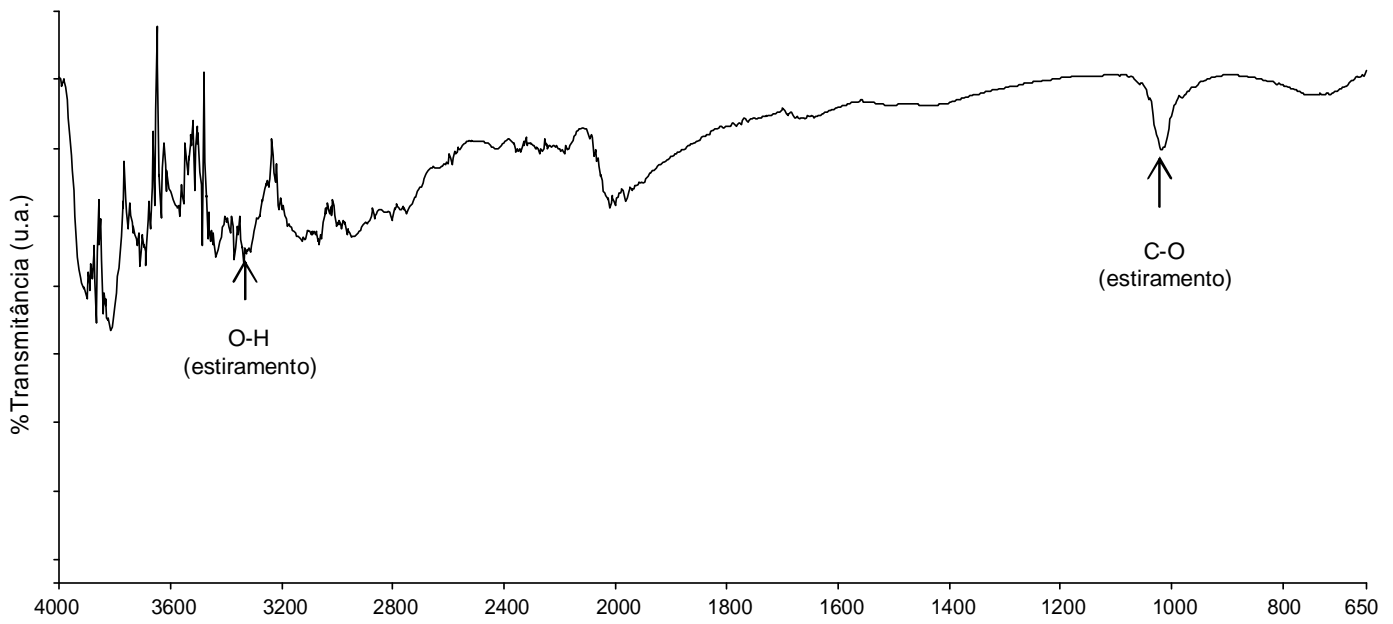

(a)

Número de onda $\left(\mathrm{cm}^{-1}\right)$

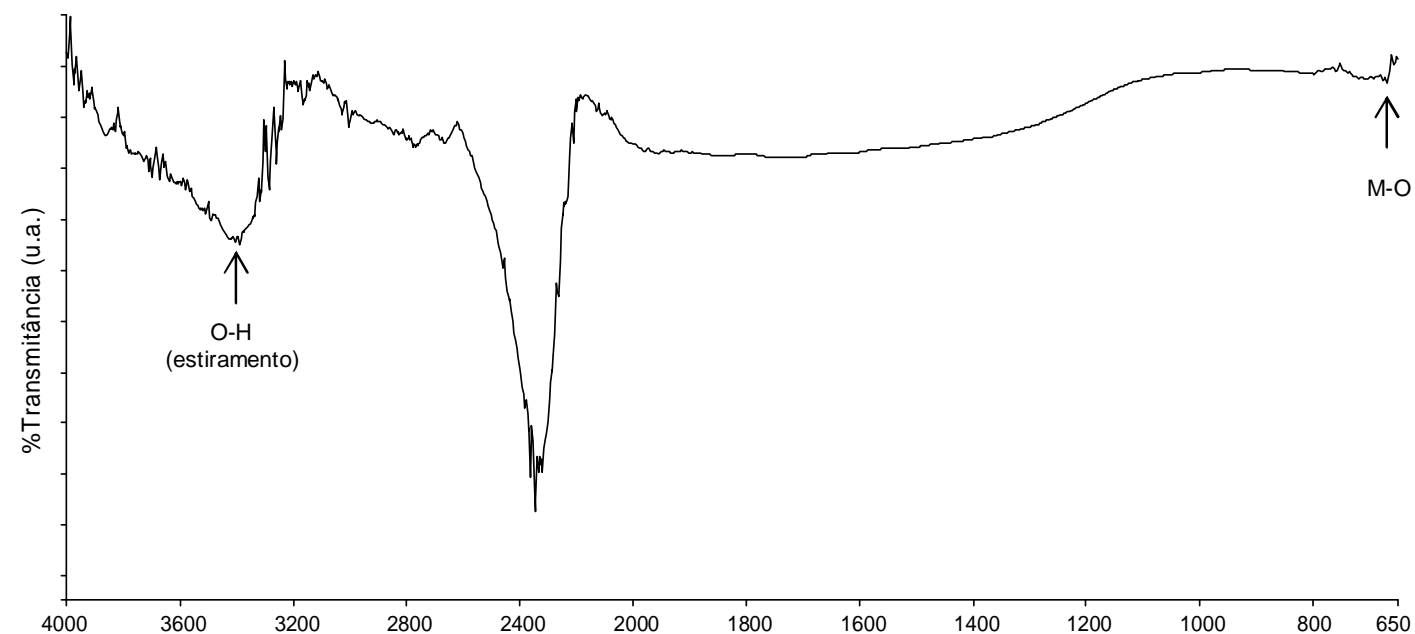

(b)

Número de onda $\left(\mathrm{cm}^{-1}\right)$

FIGURA 42 - Espectros no infravermelho médio. (a) metanol; (b) pós moídos por 18 minutos com $1,0 \%$ de metanol.

Considerando os espectros obtidos para os álcoois, também é possível sugerir que a forma de atuação desses agentes com os pós metálicos de nióbio e alumínio é semelhante à proposta para o ácido esteárico, ocorrendo uma associação desses ACPs com a superfície do alumínio por meio do oxigênio (após a quebra da ligação $\mathrm{O}-\mathrm{H}$ ). A presença de uma banda para o metanol, mostrada na FIG. 42b, próximo ao número de onda de $650 \mathrm{~cm}^{-1}$, característico de ligações oxigênio-metal, ajuda a corroborar tal afirmação. 
Nas misturas moídas com os ACPs ácido esteárico, etanol e metanol, observou-se a presença de uma banda intensa entre 2400 e $2000 \mathrm{~cm}^{-1}$ atribuída à presença de $\mathrm{CO}_{2}$ da atmosfera, a qual pode eventualmente se manifestar em razão das características de operação do equipamento utilizado.

Os resultados apresentados nos espectros no infravermelho (FIG. 40 a 42) mostram que, para tempos de moagem iguais ou inferiores a 30 minutos para o ácido esteárico, e 18 minutos para o etanol e metanol, ainda é possível distinguir a presença desses ACPs na forma livre (não associada com os pós), embora uma decomposição parcial possa ter ocorrido, conforme indicado pela presença de um pico próximo a $650 \mathrm{~cm}^{-1}$ para o metanol. Acrescida a esta constatação, a presença da fase $\mathrm{NbH}$ observada nos difratogramas de raios $\mathrm{X}$ com apenas 18 minutos de moagem, fortalece tal proposição.

\subsection{Perfis de temperatura das pastilhas reagidas}

A evolução da temperatura das pastilhas compactadas a partir das misturas moídas na condição padrão (60 minutos com 1,0\% de ACP), por 30 minutos (com $0,5 \%$ de ácido esteárico e etanol, e com 1,5\% de metanol e ciclohexano) e por 90 minutos (com $0,5 \%$ de cada agente), pode ser visualizada na FIG. 43. Os perfis de temperatura apresentados correspondem à segunda parte do ciclo térmico (após o tratamento de desgaseificação) até o final da reação de combustão. A observação desses perfis permite constatar que as pastilhas obtidas pela moagem dos pós na condição padrão sofreram ignição próxima ao patamar de fusão do alumínio $\left(\sim 660^{\circ} \mathrm{C}\right)$, indicando praticamente 0 mesmo nível de ativação mecânica para os diferentes ACPs. A comparação dos perfis de temperatura registrados nessa condição mostrou uma ignição antecipada (no tempo) nas misturas moídas com ácido esteárico e ciclohexano, em relação às misturas com etanol e metanol. Entretanto, a adição de ácido esteárico resultou em um maior tempo de fusão do alumínio (cerca de 20 segundos), em comparação com o ciclohexano. Os atrasos verificados para o início da reação devem ser analisados com cautela, uma vez que o posicionamento do termopar constitui uma fonte de variabilidade do processo. As contrações e expansões das pastilhas durante o aquecimento podem ocasionar a 
perda do contato do termopar com a superfície da pastilha (minimizando a transferência de calor desta para o termopar), o que pode acarretar em um ligeiro atraso no registro da temperatura no momento da ignição.

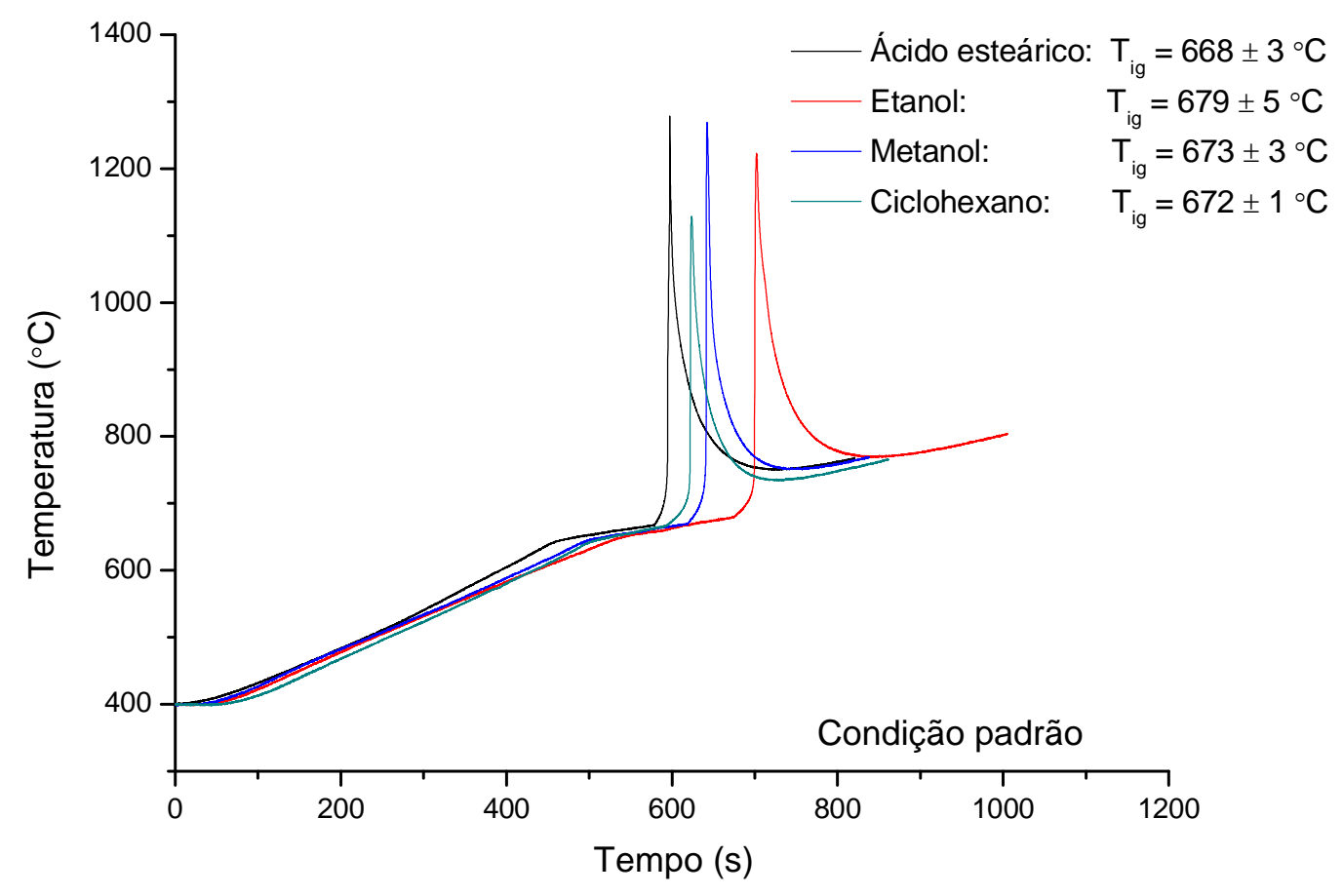

FIGURA 43 - Perfis de temperatura de pastilhas aquecidas a $30{ }^{\circ} \mathrm{C} / \mathrm{min}$ a partir das misturas moídas na condição padrão com os diferentes ACPs. 
Os comportamentos observados podem ser tentativamente explicados mediante a observação das diferentes formas com que os ACPs atuaram para impedir a soldagem excessiva durante a moagem com alta energia, como visto nos itens anteriores. Nas micrografias apresentadas no item 5.2.2 (FIG. 27), notase que nos pós moídos com ciclohexano a associação de partículas dissimilares (nióbio e alumínio) foi maior, acarretando em um menor número de partículas isoladas de nióbio, constatação também verificada na análise de imagem quantitativa $\left(\mathrm{F}_{\mathrm{vol}} \sim 0,25 \%\right)$. Tal fato contribuiu para a antecipação da temperatura de ignição, uma vez que um maior contato entre as partículas de nióbio e alumínio é favorável para o início da reação, conforme já reportado em trabalhos anteriores (Leal Neto e Rocha, 2001, 2000). Nos pós moídos com ácido esteárico, apesar de notar-se a presença de partículas isoladas de nióbio $\left(F_{\mathrm{vol}} \sim 1,2 \%\right)$, observa-se uma microestrutura composta por lamelas mais finas de nióbio nos agregados de alumínio, condição que também contribui para a antecipação da ignição.

A comparação dos perfis de temperatura para as pastilhas preparadas a partir das misturas moídas por 30 minutos com 0,5\% de ácido esteárico e etanol, e $1,5 \%$ de metanol e ciclohexano, e por 90 minutos com $0,5 \%$ de cada ACP, é mostrada nas FIG. 44 e 45. É possível observar a contribuição dos efeitos do tempo de moagem e, em menor escala, da quantidade de ACP para o início da reação. Como uma regra geral, as misturas moídas por 90 minutos acarretaram na redução nas temperaturas de ignição registradas para cada agente. Com a diminuição do tempo de moagem, houve uma elevação nas temperaturas de ignição juntamente com um atraso para o início da reação e um maior tempo de fusão do alumínio, notadamente para o agente metanol, adicionado em maior quantidade $(1,5 \%)$ nas misturas moídas por 30 minutos.

Ao estabelecer um comparativo com as microestruturas (FIG. 28), nota-se que nos pós moídos com um menor tempo de moagem (condição que gerou maiores densidades relativas), há um maior número de partículas isoladas de nióbio e a presença de uma microestrutura rica em alumínio contendo partículas incrustadas de nióbio. No caso do agente ciclohexano, o aumento na temperatura de ignição para 30 minutos de moagem ocorreu principalmente em razão da presença de agregados grosseiros. 


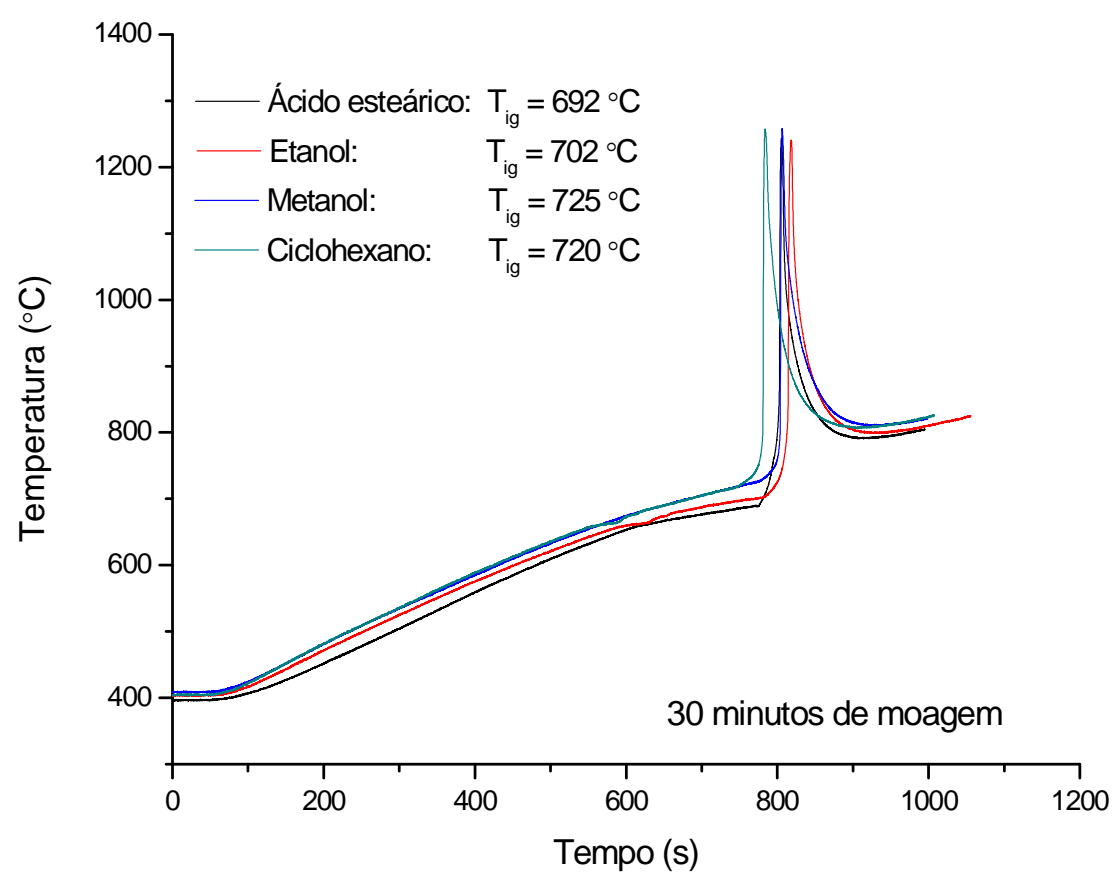

FIGURA 44 - Perfis de temperatura de pastilhas aquecidas a $30{ }^{\circ} \mathrm{C} / \mathrm{min}$ a partir das misturas moídas por 30 minutos. Ácido esteárico e etanol $(0,5 \%)$; metanol e ciclohexano $(1,5 \%)$.

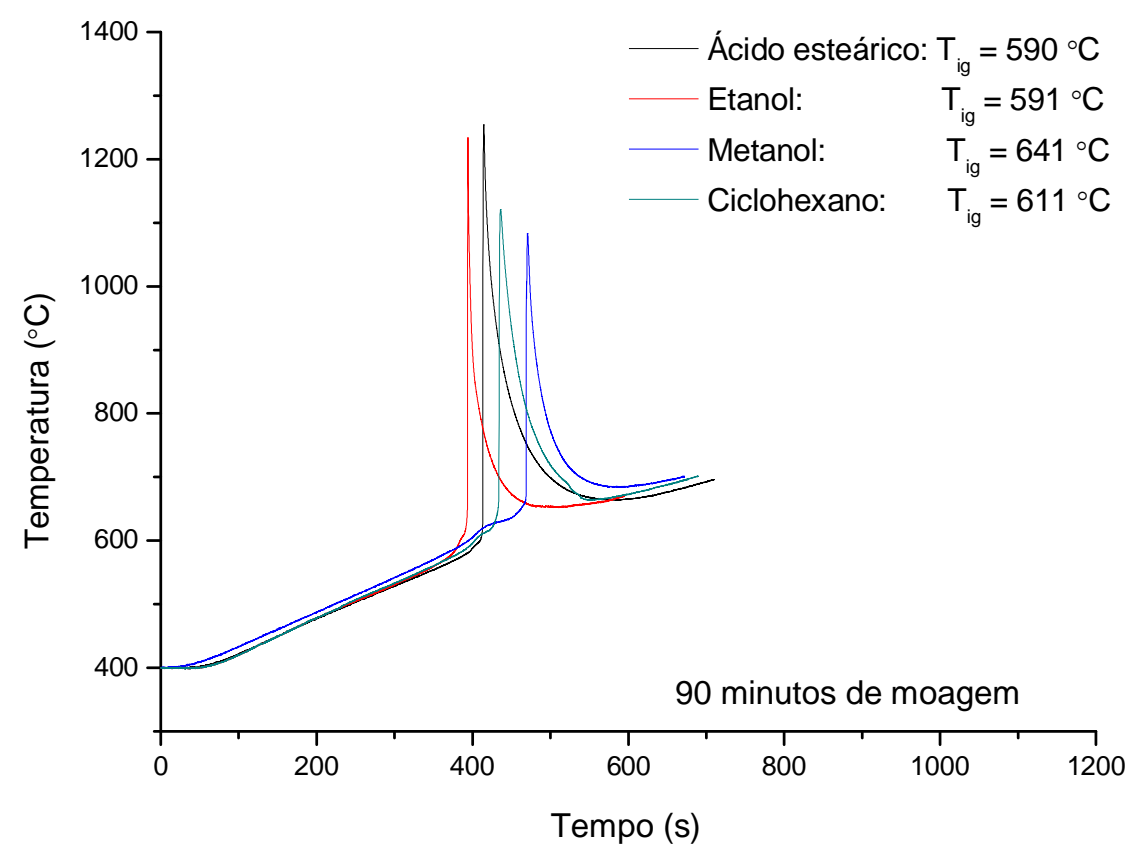

FIGURA 45 - Perfis de temperatura de pastilhas aquecidas a $30{ }^{\circ} \mathrm{C} / \mathrm{min}$ a partir das misturas moídas por 90 minutos com $0,5 \%$ de cada ACP. 
Nos pós moídos por 90 minutos com 0,5\% de ACP (condição que gerou menores densidades relativas), a microestrutura dos agregados é composta por lamelas altamente refinadas. O início da reação é significativamente afetado pela variável tempo de moagem e, consequentemente, pelo grau de refinamento da microestrutura dos agregados e pela fração volumétrica de partículas isoladas de nióbio. Quanto maior o contato entre partículas dissimilares, maior é a reatividade dos reagentes para o início da reação. Na mistura moída com metanol, verificouse um atraso para o início da reação e um maior tempo de fusão do alumínio, fatos que podem ter contribuído para a maior densidade relativa verificada para esse agente.

Nos perfis de temperatura agrupados por tipo de ACP para um mesmo tempo de moagem (FIG. 46 a 48), torna-se mais evidente o efeito da quantidade do agente. Como uma tendência geral, a adição de uma maior quantidade de ACP provocou um aumento nas temperaturas de ignição e nos tempos de fusão do alumínio, bem como em um atraso nas reações (exceção para as misturas moídas com ácido esteárico por 30 minutos e ciclohexano por 90 minutos, fatos que podem ser atribuídos ao posicionamento do termopar), deslocando os perfis de temperatura levemente para a direita. As maiores temperaturas de ignição registradas podem estar associadas com a diminuição no grau de soldagem entre as partículas, verificada nas moagens com uma maior quantidade de agente e constatada pelas análises de imagens quantitativas. Os aumentos nas temperaturas de ignição foram mais significativos nas misturas moídas por 30 minutos com ácido esteárico e etanol (FIG. 46a e b), e menos pronunciados para as misturas moídas com metanol e ciclohexano.

A partir dos resultados reportados, relativos aos efeitos dos agentes nas temperaturas de ignição, a seguinte consideração pode ser formulada: em um primeiro momento, verificou-se que a adição de uma maior quantidade de ACP é benéfica no sentido de manter um equilíbrio entre os eventos de soldagem e fratura durante a moagem, conforme apresentado nas micrografias do item 5.2.2; no entanto, tal efeito também está diretamente relacionado ao tempo de moagem, conforme verificado nos resultados dos planejamentos de experimentos. $\mathrm{Na}$ prática, observou-se que um menor tempo de moagem, associado a uma maior quantidade de ACP acarretou em um aumento nas temperaturas de ignição e em 
um atraso nas reações de combustão. Esse aumento foi mais significativo para os agentes ácido esteárico e etanol, especialmente para tempos de moagem inferiores a 60 minutos, sendo mais um indício de que estes ACPs exercem uma influência mais pronunciada na ativação mecânica em comparação aos outros agentes.

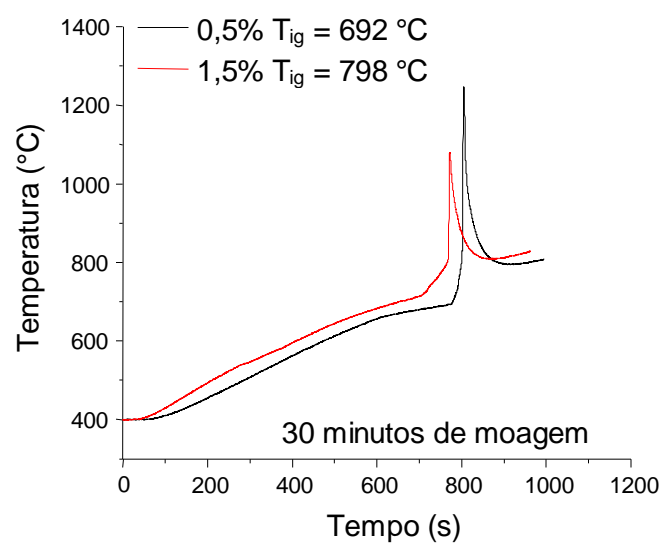

(e) Ácido esteárico

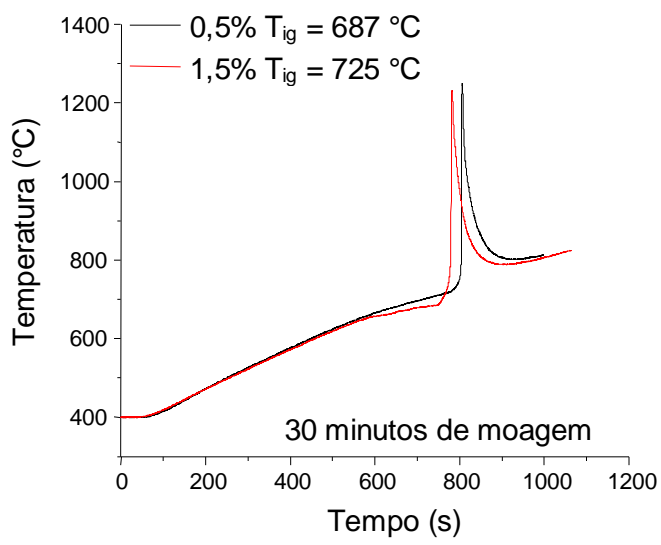

(g) Metanol

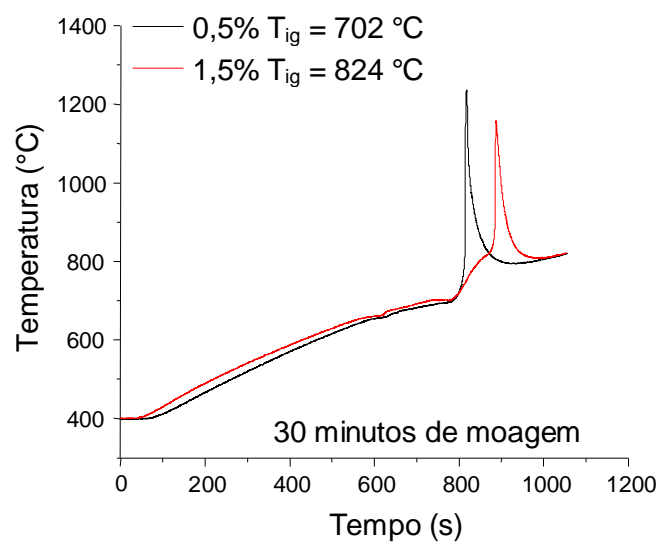

(f) Etanol

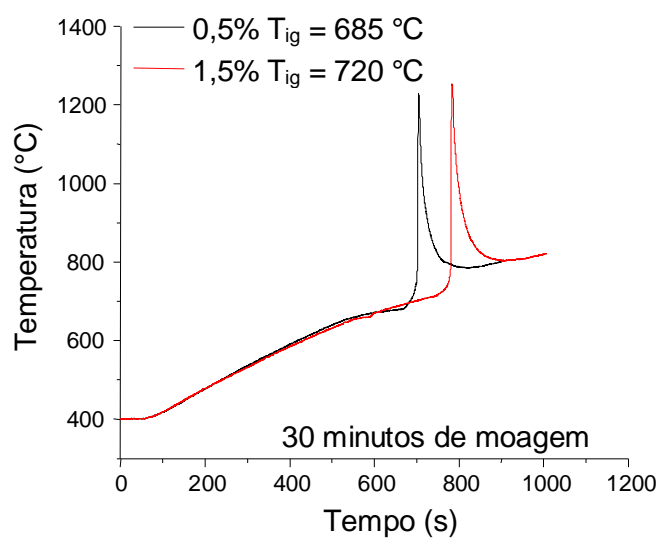

(h) Ciclohexano

FIGURA 46 - Perfis de temperatura de pastilhas aquecidas a $30{ }^{\circ} \mathrm{C} / \mathrm{min}$ a partir das misturas moídas por 30 minutos com 0,5 e 1,5\% de cada ACP. 


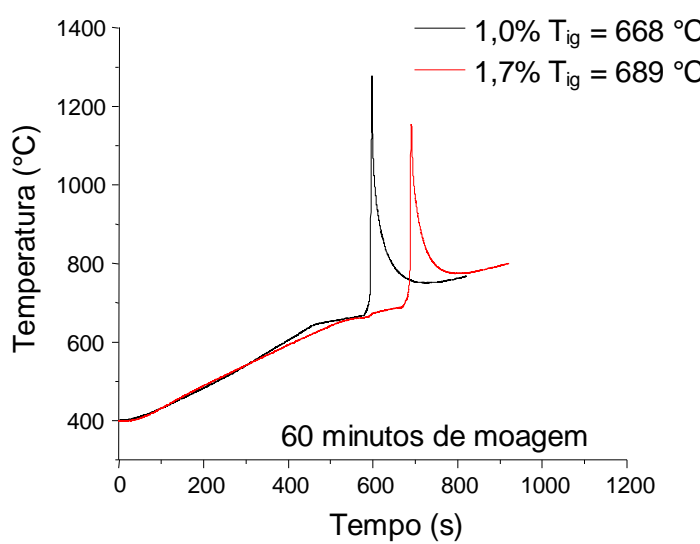

(a) Ácido esteárico

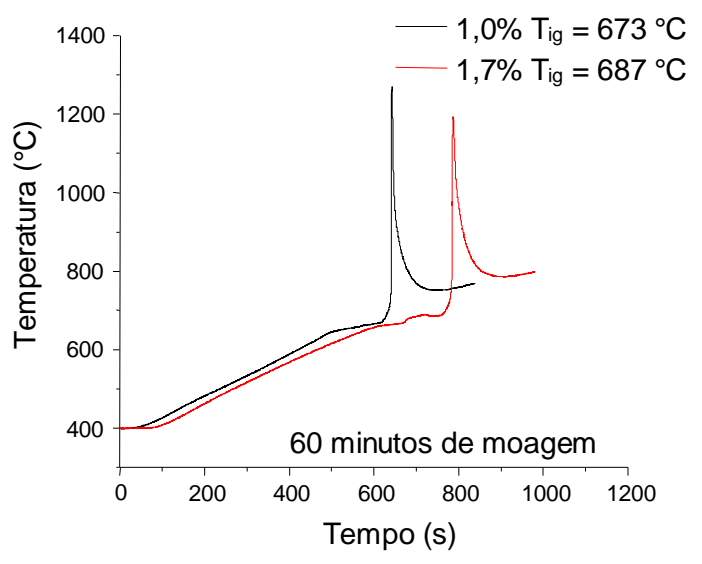

(c) Metanol

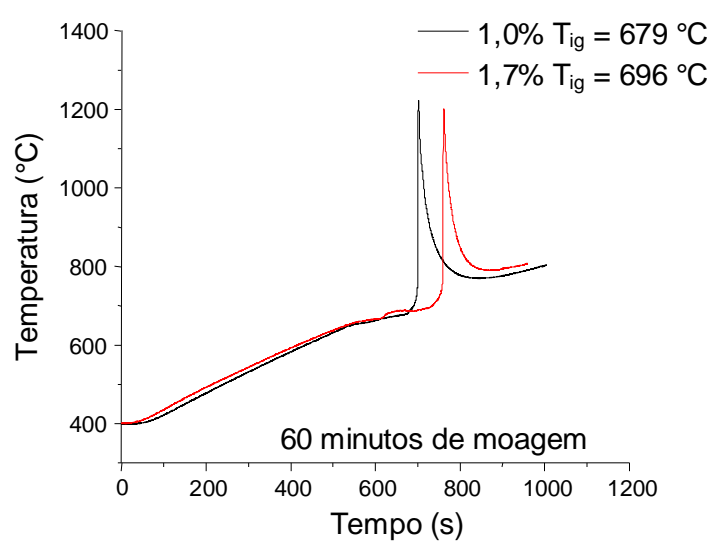

(b) Etanol

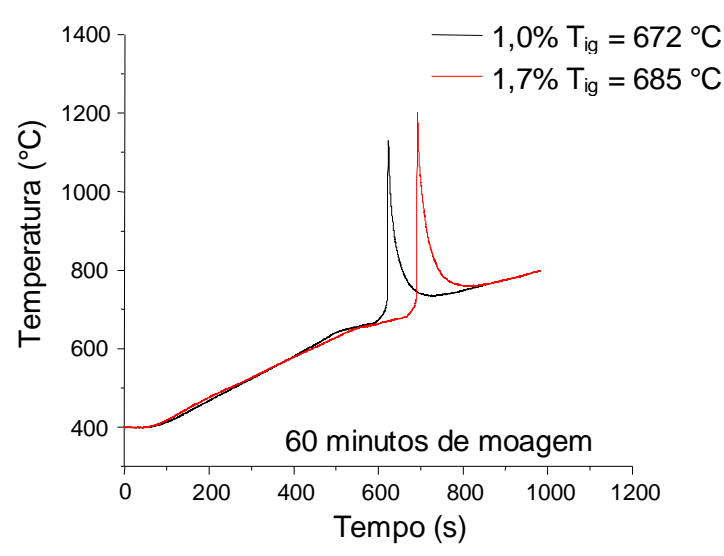

(d) Ciclohexano

FIGURA 47 - Perfis de temperatura de pastilhas aquecidas a $30{ }^{\circ} \mathrm{C} / \mathrm{min}$ a partir das misturas moídas por 60 minutos com 1,0 e 1,7\% de cada ACP. 


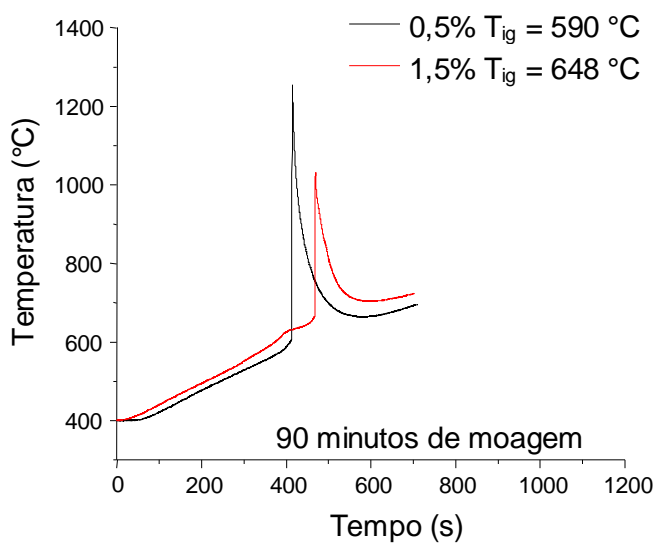

(a) Ácido esteárico

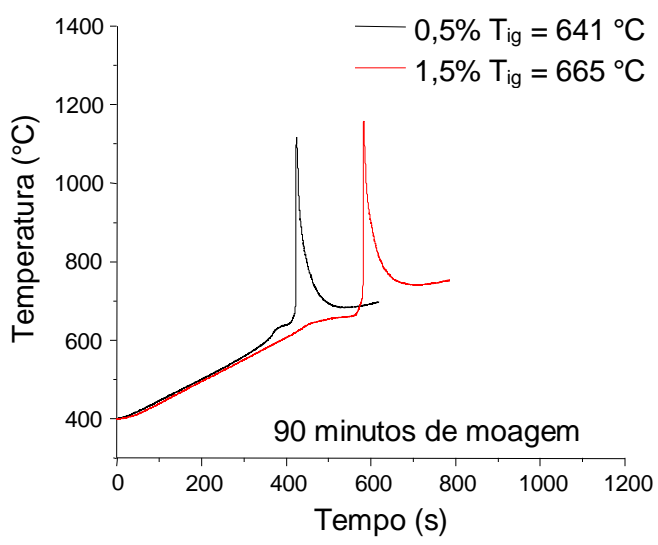

(c) Metanol

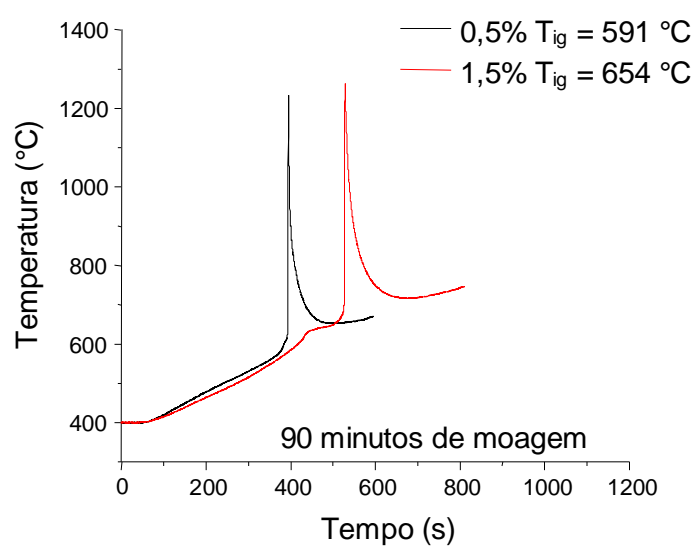

(b) Etanol

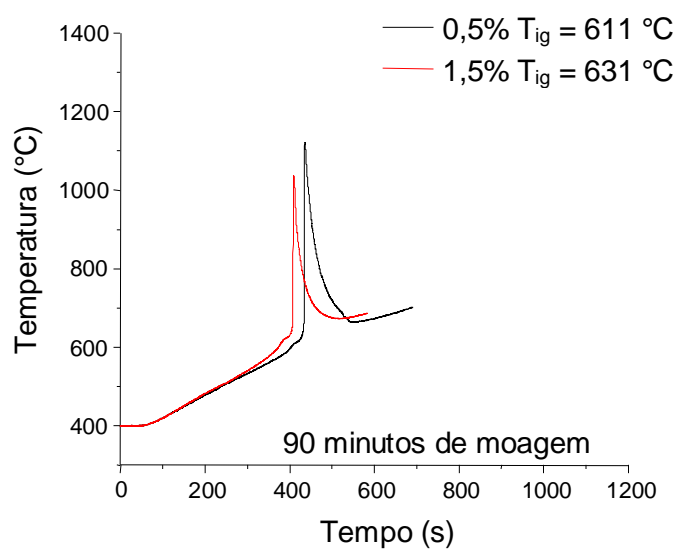

(d) Ciclohexano

FIGURA 48 - Perfis de temperatura de pastilhas aquecidas a $30{ }^{\circ} \mathrm{C} / \mathrm{min}$ a partir das misturas moídas por 90 minutos com 0,5 e 1,5\% de cada ACP. 


\subsection{Caracterização das pastilhas reagidas}

A caracterização das pastilhas reagidas foi realizada com o propósito de determinar as densidades relativas do $\mathrm{NbAl}_{3}$ obtidas após reação (apresentadas no item 5.1), e verificar o aspecto da porosidade interna e a completitude da reação de combustão, relacionando tais características com as diferentes condições de processamento utilizadas para a preparação das misturas de $\mathrm{Nb75Al}$. Os resultados obtidos por microscopia eletrônica de varredura, análise de imagem quantitativa e difração de raios $X$, são apresentados nos próximos itens.

\subsubsection{Microestrutura das pastilhas reagidas}

As microestruturas das pastilhas reagidas e processadas a partir das misturas moídas na condição padrão com os diferentes ACPs estão apresentadas na FIG. 49. Nessa condição, o agente ciclohexano gerou pastilhas com poros grosseiros e interconectados em algumas regiões, o que foi refletido nas baixas densidades relativas obtidas. Os agentes ácido esteárico, etanol e metanol apresentaram poros arredondados com menores dimensões.

$\mathrm{Na}$ FIG. 50 são apresentadas as microestruturas das pastilhas processadas por 30 e 90 minutos de moagem, nas condições que geraram, respectivamente, as densidades relativas mais elevadas e as mais baixas. $O$ processamento das misturas com um menor tempo de moagem produziu pastilhas com poros de dimensões levemente inferiores àqueles das amostras preparadas na condição padrão (exceção para o etanol, cujo formato dos poros indica um possível aprisionamento de gases). No caso das misturas moídas por 90 minutos com $0,5 \%$ de $A C P$, verificou-se uma grande quantidade de poros interconectados para todos os agentes utilizados.

Em todas as pastilhas a fase majoritária identificada foi $\circ \mathrm{NbAl}_{3}$ (representado pela tonalidade cinza clara nas imagens da FIG. 51), mediante análise por espectroscopia por energia dispersiva (EDS). A presença de partículas com alto teor de alumínio e oxigênio (tonalidade cinza escura), e partículas com alto teor de nióbio e carbono (tonalidade clara), ambas finamente distribuídas na matriz de $\mathrm{NbAl}_{3}$, também foi detectada nessa análise e nas micrografias eletrônicas de varredura (FIG. 51). O constituinte eutético 
$\mathrm{Nb}_{2} \mathrm{Al}-\mathrm{NbAl}_{3}$ (regiões claras mostradas na FIG. 50 e, em maior aumento, na FIG. $51 \mathrm{a}$ e b) foi identificado nas pastilhas processadas para tempos de moagem iguais e inferiores a 30 minutos. A presença desse constituinte pode ser atribuída a pequenos desvios na estequiometria do composto (com perda de alumínio por evaporação durante a reação), em razão de heterogeneidades na dispersão dos reagentes, que contém agregados ricos em alumínio e pobres em nióbio.

A fração volumétrica do constituinte eutético (regiões claras) observado nas FIG. 50 e 51 foi quantificada por análise de imagem da microestrutura das pastilhas processadas a partir das misturas moídas por 30 minutos com os agentes ácido esteárico (0,5\%) e metanol (1,5\%). O procedimento adotado foi semelhante ao aplicado nas análises dos pós moídos, com o auxílio do software Quantikov (Pinto, 1996), após tratamento manual das imagens no programa Adobe Photoshop ${ }^{\circledR}$ CS3. As análises foram efetuadas em 10 regiões distintas para cada condição, em micrografias obtidas com aumentos de $300 \times$. Os resultados obtidos estão apresentados na TAB. 25.

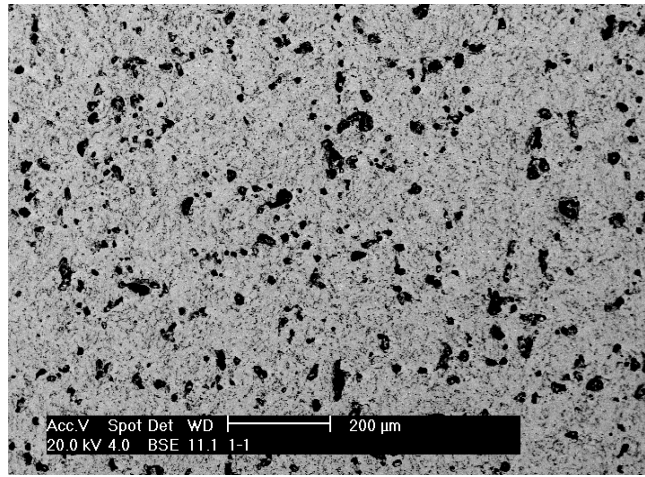

Ácido esteárico $(89,41 \%)$

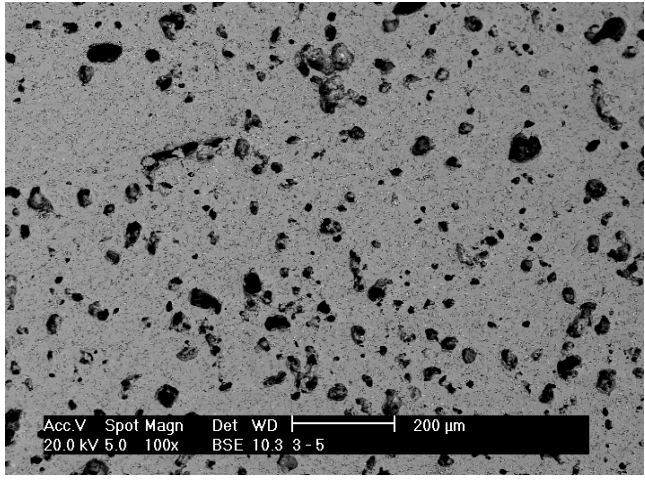

Metanol $(88,85 \%)$

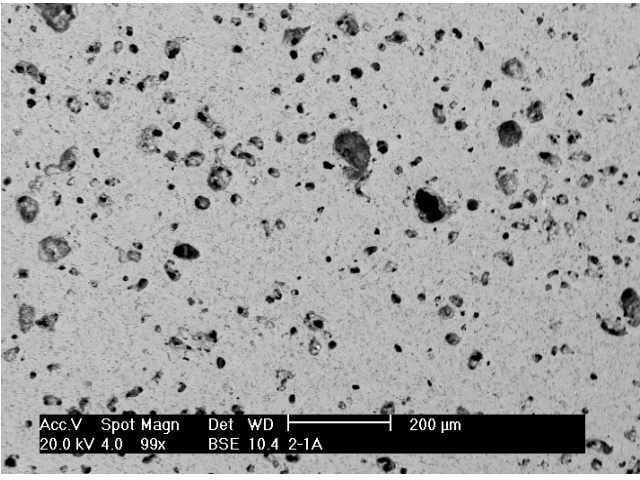

Etanol $(92,12 \%)$

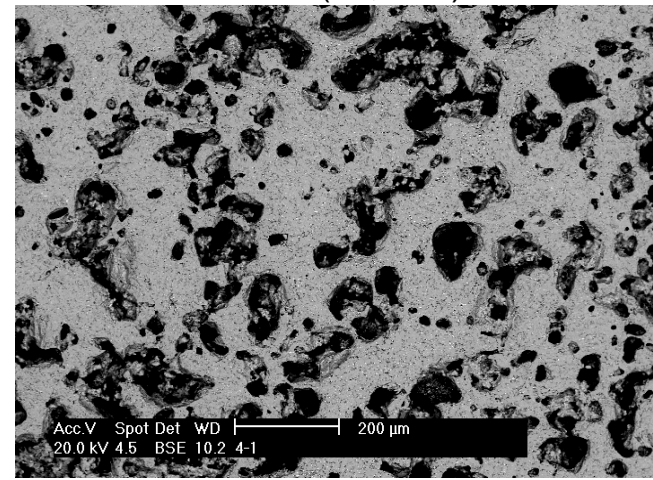

Ciclohexano $(77,36 \%)$

FIGURA 49 - Micrografias eletrônicas de varredura (elétrons retroespalhados) das pastilhas reagidas e processadas na condição padrão. 


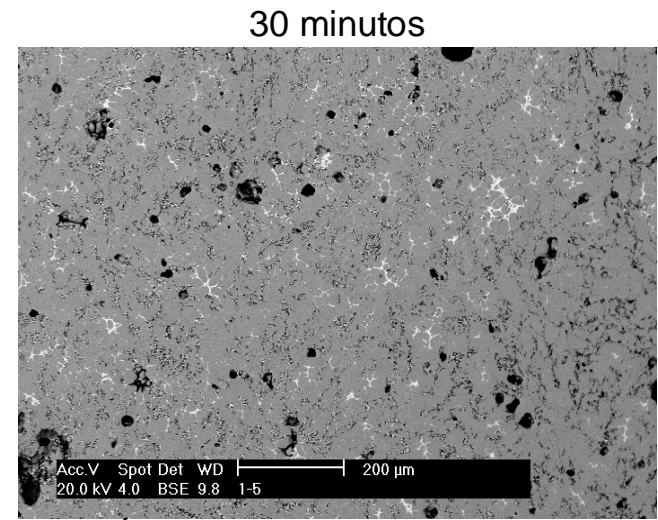

(a) Ácido esteárico: 0,5\% (95,88\%)

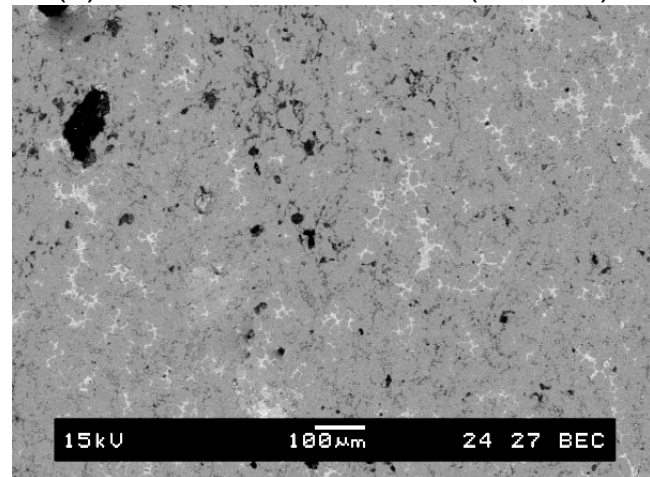

(c) Etanol: 0,5\% (96,05\%)

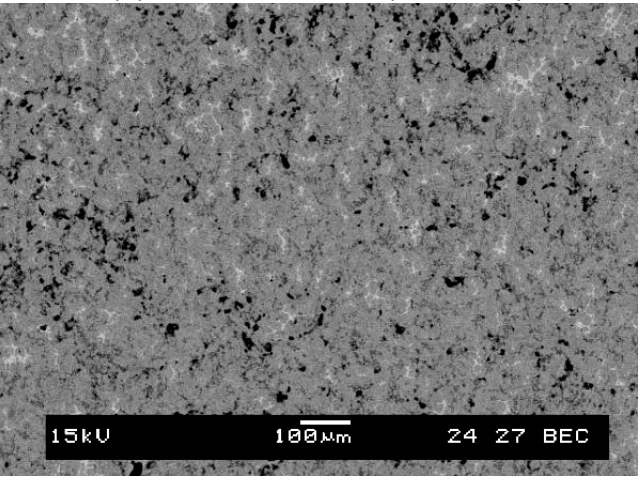

(e) Metanol: 1,5\% (94,88\%)

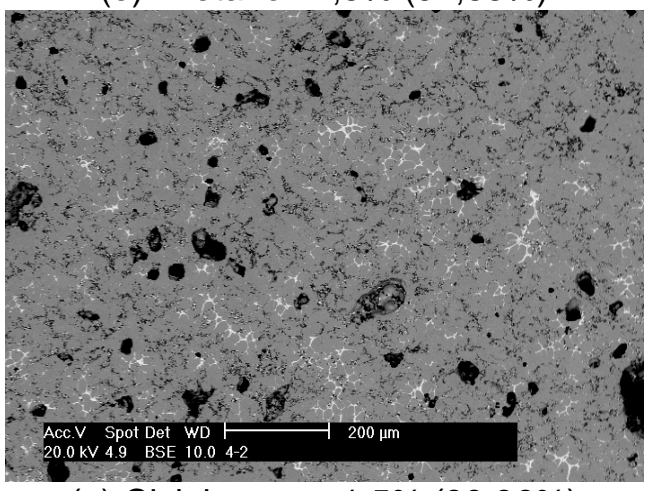

(g) Ciclohexano: 1,5\% (90,96\%)
90 minutos

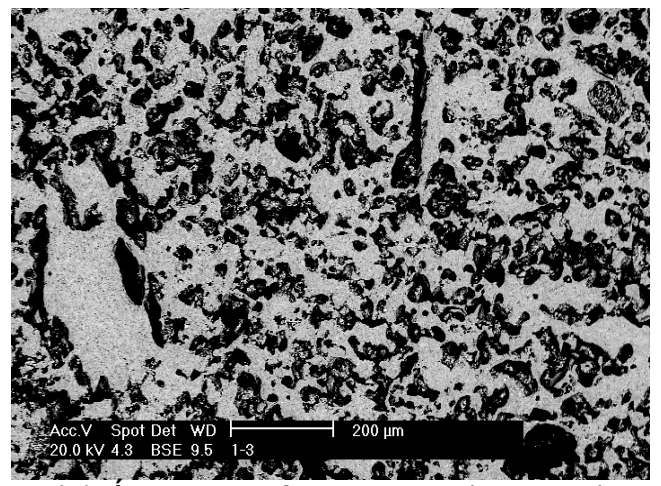

(b) Ácido esteárico: 0,5\% (72,90\%)

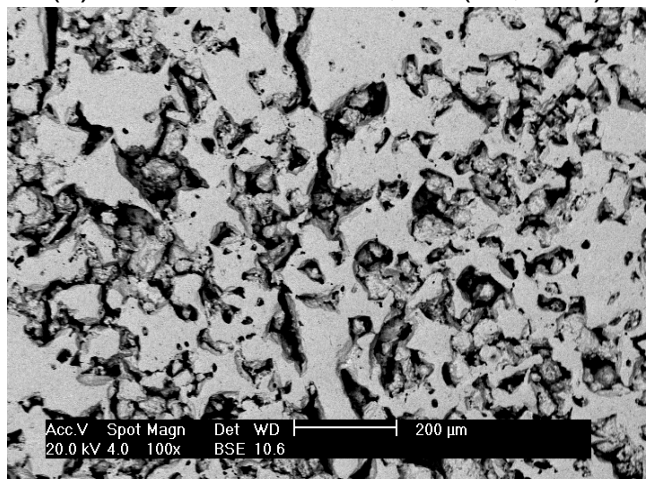

(d) Etanol: 0,5\% (72,94\%)

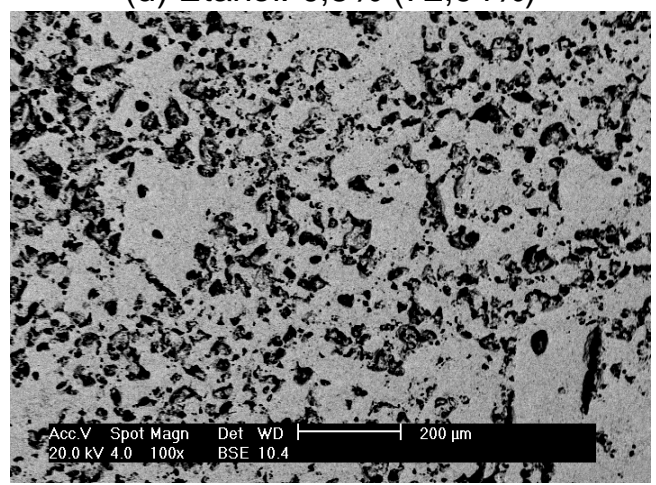

(f) Metanol: 0,5\% (74,83\%)

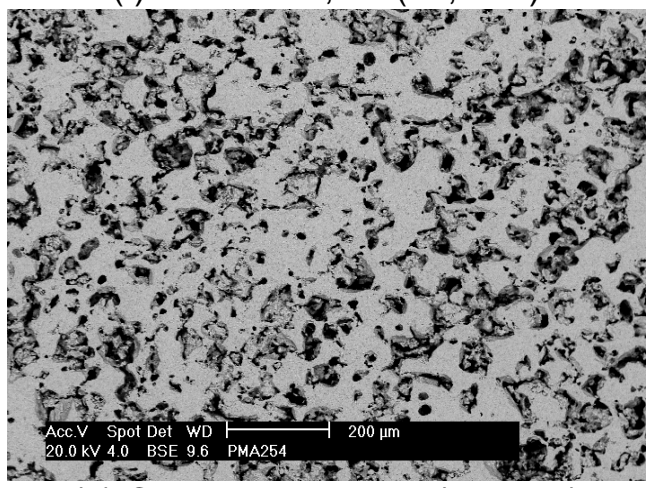

(h) Ciclohexano: 0,5\% (71,22\%)

FIGURA 50 - Micrografias eletrônicas de varredura (elétrons retroespalhados) das pastilhas reagidas e processadas a partir das misturas moídas por 30 e 90 minutos com os diferentes ACPs. 


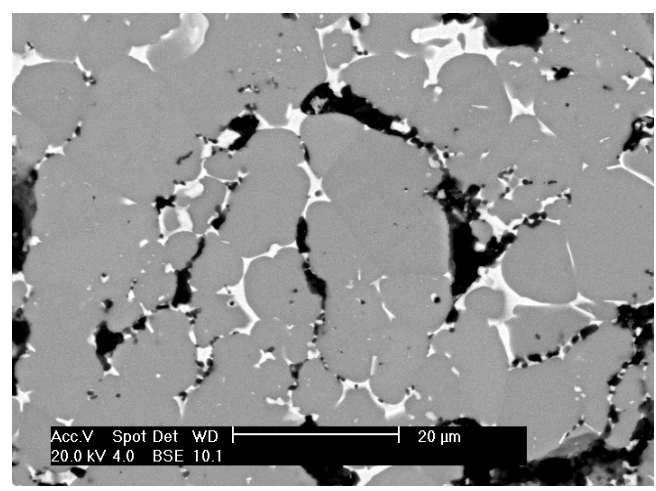

(a)

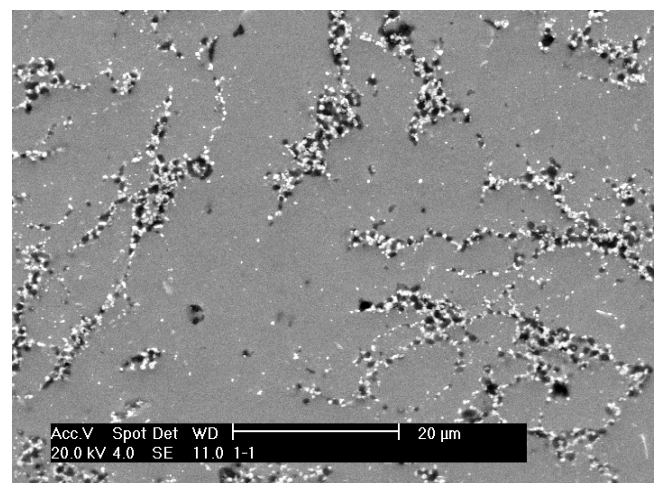

(c)

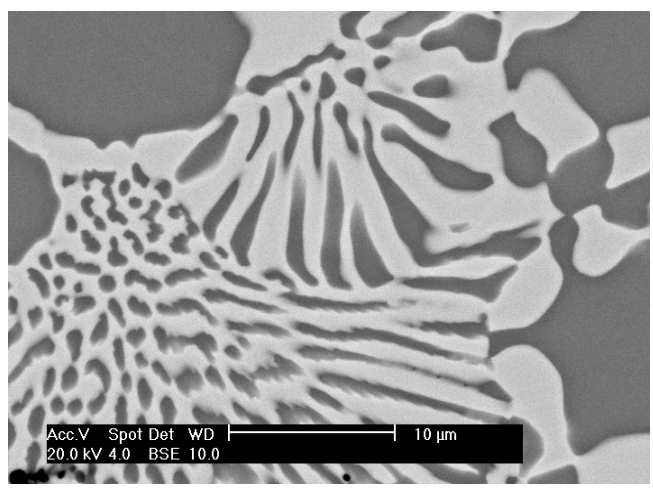

(b)

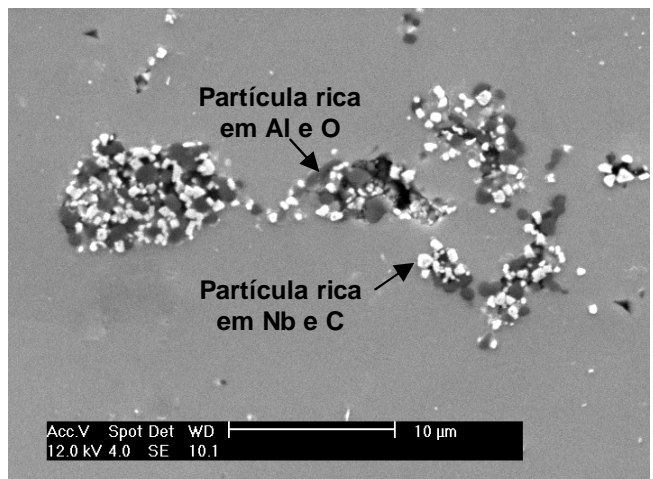

(d)

FIGURA 51 - Micrografias eletrônicas de varredura (elétrons retroespalhados: a e b; e secundários: c e d) das pastilhas reagidas a partir das misturas moídas por 30 minutos. (a) e (b): detalhe do constituinte eutético $\mathrm{Nb}_{2} \mathrm{Al}-\mathrm{NbAl}_{3}$; (c) e (d): detalhe das partículas com alto teor de alumínio e oxigênio (tonalidade cinza escura) e partículas com alto teor de nióbio e carbono (tonalidade clara).

TABELA 25 - Fração volumétrica do constituinte eutético das pastilhas reagidas a partir das misturas moídas por 30 minutos.

\begin{tabular}{|c|c|c|c|c|}
\hline ACP & $\begin{array}{c}\text { Tempo de } \\
\text { moagem } \\
\text { (minutos) }\end{array}$ & $\begin{array}{c}\text { Quantidade } \\
\text { de ACP } \\
(\%)\end{array}$ & $\begin{array}{c}\mathbf{F}_{\text {vol média da fase }} \\
\text { clara }\left(\mathbf{N b}_{2} \mathbf{A l}-\mathbf{N b A l}_{3}\right) \\
\mathbf{( \% )}\end{array}$ & $\begin{array}{c}\text { Desvio } \\
\text { padrão das } \\
\text { medidas }\end{array}$ \\
\hline Ácido esteárico & 30 & 0,5 & 1,30 & $\pm 0,25$ \\
\hline Metanol & 30 & 1,5 & 1,51 & $\pm 0,32$ \\
\hline
\end{tabular}

Os resultados apresentados na TAB. 25 mostram praticamente a mesma fração volumétrica da fase clara para ambas as misturas, independentemente, nesse caso específico, da quantidade de agente utilizada. Tais dados indicam que a presença do constituinte eutético pode ser atribuída principalmente à variável 
tempo de moagem, uma vez que nas moagens superiores a 30 minutos, o constituinte eutético não foi observado. Quanto menor o tempo, maior é a heterogeneidade na dispersão dos reagentes, acarretando em um aumento nas temperaturas de ignição (conforme notado no item 5.3) e, consequentemente, em uma maior perda de alumínio por evaporação. Essa perda de alumínio também pôde ser verificada a partir das massas das pastilhas após reação. A diferença entre as massas das pastilhas reagida e compactada a partir das misturas moídas por 30 minutos foi de $0,1 \mathrm{~g}$, ao passo que para as moagens iguais e superiores a 60 minutos essa diferença foi de apenas $0,03 \mathrm{~g}$.

\subsubsection{Difração de raios $X$ das pastilhas reagidas}

As misturas moídas por 30 minutos com 0,5\% de ácido esteárico e etanol, e com 1,5\% de metanol e ciclohexano (condição que gerou maiores densidades relativas), 60 minutos com 1,0\% de cada ACP (condição padrão) e 90 minutos com $0,5 \%$ de cada ACP (condição que gerou menores densidades relativas), foram analisadas qualitativamente por difração de raios X. Essa análise teve como intuito verificar a completitude da reação e avaliar a estequiometria das partículas observadas na FIG. 51c e d. Os difratogramas destas pastilhas são apresentados nas FIG. 52 a 54.

$\mathrm{O} \mathrm{NbAl}{ }_{3}$, tal como observado nas micrografias eletrônicas de varredura, é a fase majoritária em todas as condições analisadas. Os picos de difração das fases correspondentes às partículas com tonalidades cinza escura e clara, presentes na FIG. 51c e d, também foram observadas nos difratogramas e identificadas como óxido de alumínio $\left(\mathrm{Al}_{2} \mathrm{O}_{3}\right)$, fase mais escura e carbeto de nióbio ( $\mathrm{NbC}$ ), fase mais clara. A explicação mais provável para a formação dessas partículas é a de que estas sejam provenientes de reações (ativadas pelo aquecimento durante o ciclo térmico para a reação de combustão) entre os pós metálicos e os elementos carbono e oxigênio disponibilizados por uma decomposição parcial dos ACPs. Essa decomposição parcial pôde ser observada já para 30 minutos de moagem. A presença da fase correspondente ao $\mathrm{Al}_{2} \mathrm{O}_{3}$ nas misturas moídas com o agente ciclohexano indica que o oxigênio fornecido foi proveniente de outras fontes. A ausência dos picos relativos ao $\mathrm{NbH}$ (observados 


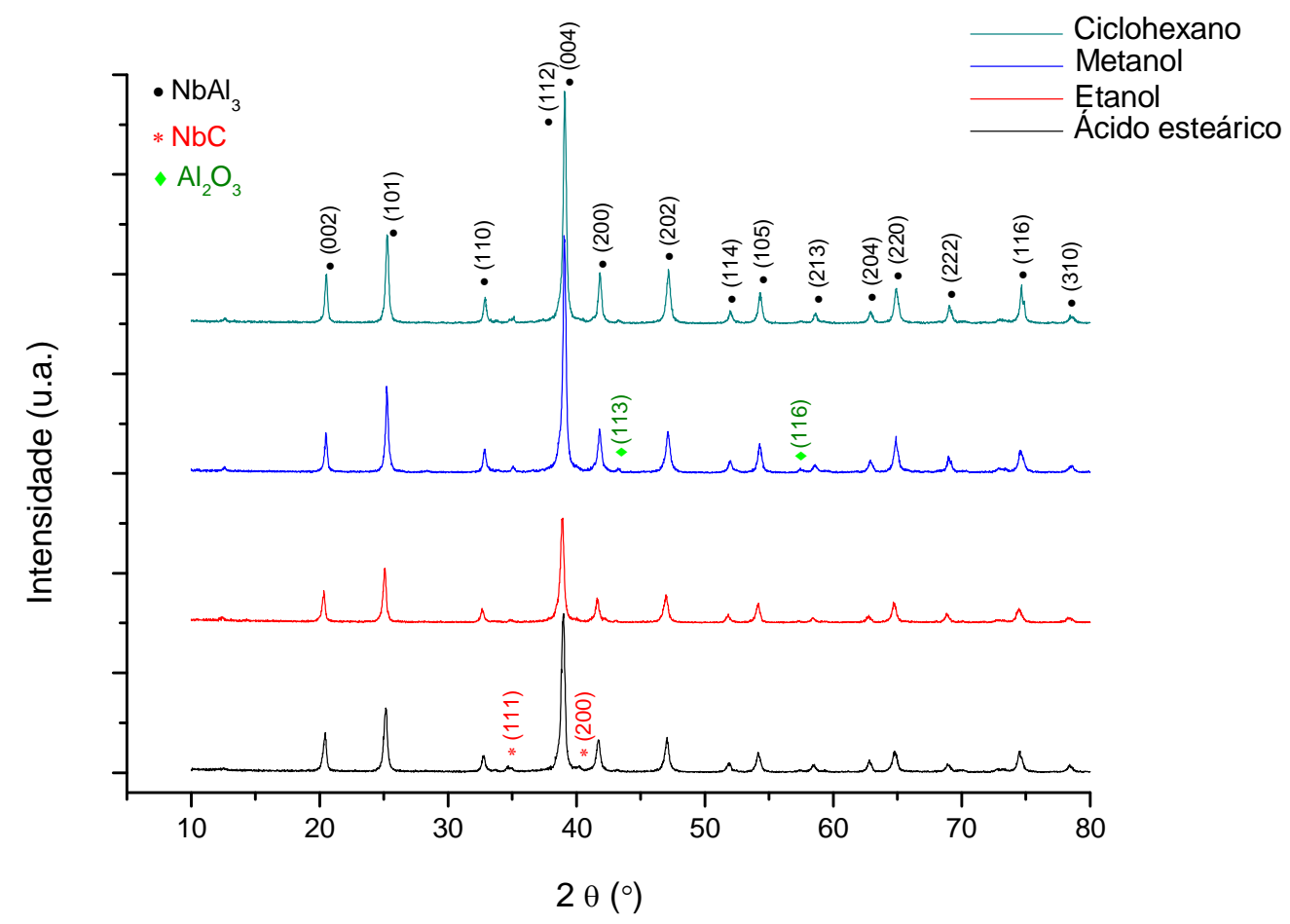

FIGURA 52 - Difratogramas de raios $X$ das pastilhas reagidas a partir das misturas processadas por 30 minutos. Ácido esteárico e etanol $(0,5 \%)$; metanol e ciclohexano $(1,5 \%)$.

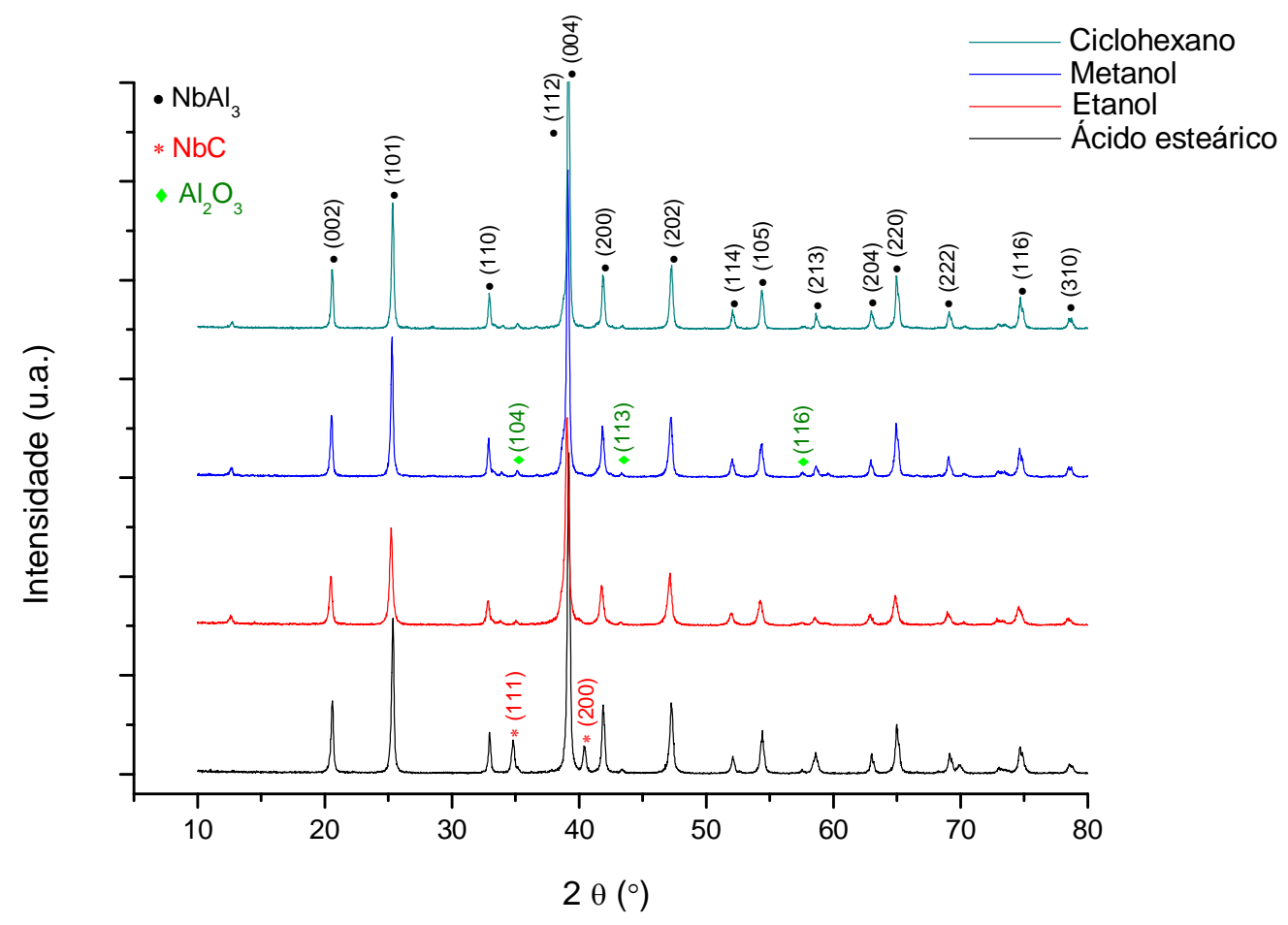

FIGURA 53 - Difratogramas de raios $X$ das pastilhas reagidas a partir das misturas processadas por 60 minutos com $1,0 \%$ de cada ACP. 


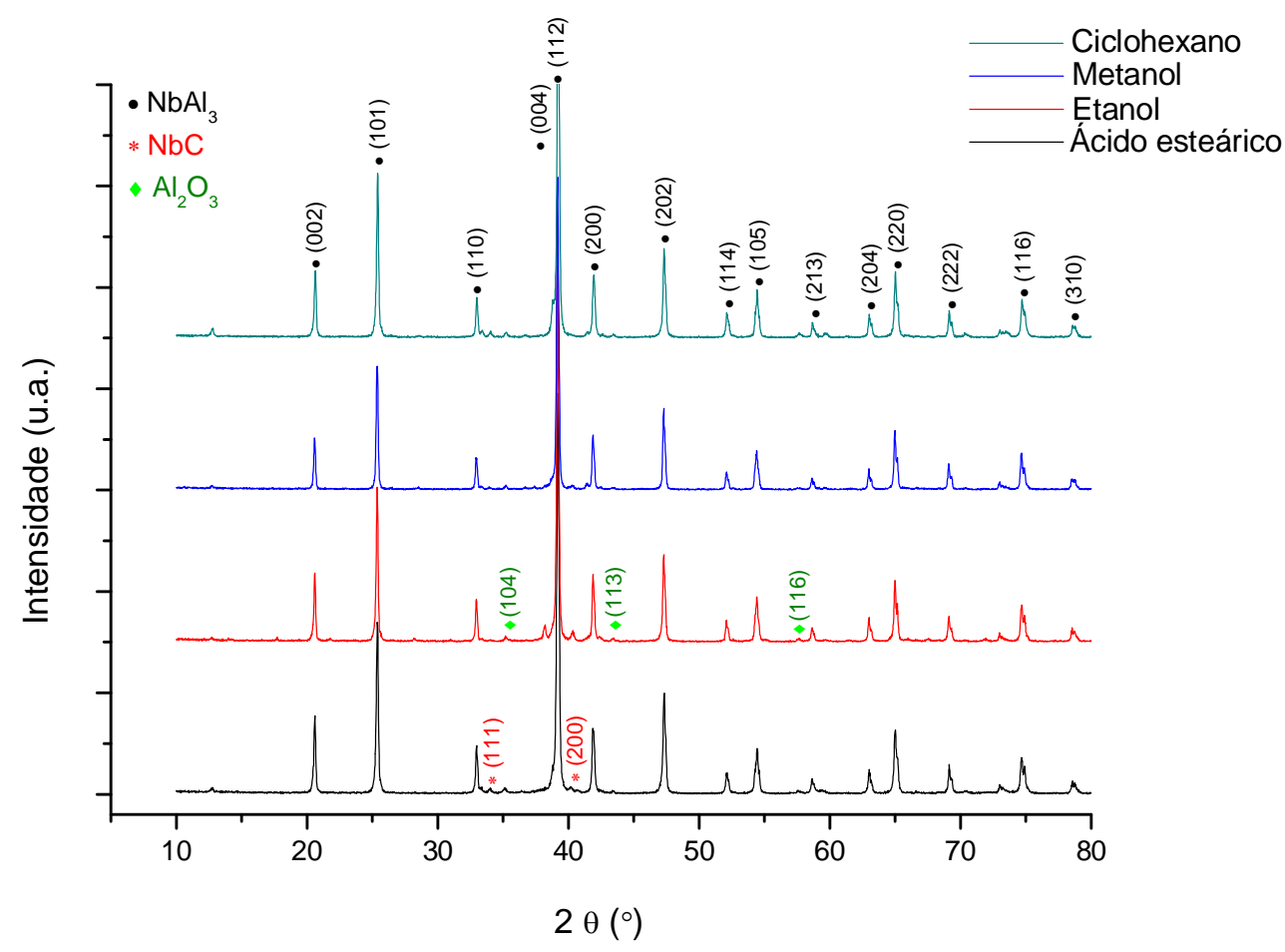

FIGURA 54 - Difratogramas de raios X das pastilhas reagidas a partir das misturas processadas por 90 minutos com $0,5 \%$ de cada ACP.

nas misturas moídas) indica que ocorreu a dessorção do hidrogênio no nióbio durante o tratamento térmico para a reação de combustão.

\subsection{Síntese dos principais resultados obtidos na caracterização dos pós moídos e das pastilhas reagidas}

Os resultados obtidos na caracterização dos pós moídos e das pastilhas reagidas, juntamente com a análise dos perfis de temperatura registrados durante as reações de combustão, auxiliaram o melhor entendimento sobre a influência e a forma de atuação dos diferentes ACPs (especialmente dos agentes ácido esteárico, etanol e metanol) no que concerne à interação destes com os pós moídos e sua influência nas densidades relativas das pastilhas de $\mathrm{NbAl}_{3}$ obtidas após reação. Os dados referentes às densidades e temperaturas de ignição estão apresentados na TAB. 26 para as misturas processadas por 30, 60 e 90 minutos de moagem com diferentes quantidades dos agentes. 
TABELA 26 - Temperaturas de ignição $\left(T_{\text {ig }}\right)$ e densidades relativas das pastilhas de $\mathrm{NbAl}_{3}$.

\begin{tabular}{|c|c|c|c|c|}
\hline ACP & $\begin{array}{l}\text { Tempo de } \\
\text { moagem } \\
\text { (minutos) }\end{array}$ & $\begin{array}{l}\text { Quantidade de } \\
\text { ACP } \\
(\%)\end{array}$ & $\begin{array}{c}\mathrm{T}_{\mathrm{ig}} \\
\left({ }^{\circ} \mathrm{C}\right)\end{array}$ & $\begin{array}{l}\text { Densidade } \\
\text { relativa } \\
\left(\% d_{t}\right)^{*}\end{array}$ \\
\hline \multirow{6}{*}{ Ácido esteárico } & \multirow{2}{*}{30} & 0,5 & 692 & 95,88 \\
\hline & & 1,5 & 798 & 82,94 \\
\hline & \multirow{2}{*}{60} & 1,0 & $668 \pm 3$ & $89,41 \pm 1,44$ \\
\hline & & 1,7 & 689 & 92,62 \\
\hline & \multirow{2}{*}{90} & 0,5 & 590 & 72,90 \\
\hline & & 1,5 & 648 & 83,84 \\
\hline \multirow{6}{*}{ Etanol } & \multirow{2}{*}{30} & 0,5 & 702 & 96,05 \\
\hline & & 1,5 & 824 & 77,68 \\
\hline & \multirow{2}{*}{60} & 1,0 & $679 \pm 5$ & $92,12 \pm 1,02$ \\
\hline & & 1,7 & 696 & 86,43 \\
\hline & \multirow{2}{*}{90} & 0,5 & 591 & 72,94 \\
\hline & & 1,5 & 654 & 84,29 \\
\hline \multirow{6}{*}{ Metanol } & \multirow{2}{*}{30} & 0,5 & 687 & 87,24 \\
\hline & & 1,5 & 725 & 94,88 \\
\hline & \multirow{2}{*}{60} & 1,0 & $673 \pm 3$ & $88,85 \pm 1,09$ \\
\hline & & 1,7 & 687 & 89,00 \\
\hline & \multirow{2}{*}{90} & 0,5 & 641 & 74,83 \\
\hline & & 1,5 & 665 & 85,04 \\
\hline \multirow{6}{*}{ Ciclohexano } & \multirow{2}{*}{30} & 0,5 & 685 & 82,70 \\
\hline & & 1,5 & 720 & 90,96 \\
\hline & \multirow{2}{*}{60} & 1,0 & $672 \pm 1$ & $77,36 \pm 0,92$ \\
\hline & & 1,7 & 685 & 84,01 \\
\hline & \multirow{2}{*}{90} & 0,5 & 611 & 71,22 \\
\hline & & 1,5 & 631 & 72,94 \\
\hline
\end{tabular}

${ }^{*} d_{t}=4,54 \mathrm{~g} / \mathrm{cm}^{3}$ (densidade teórica do $\mathrm{NbAl}_{3}$ ) 
A análise da TAB. 26 permite constatar que a adição de uma maior quantidade de $\mathrm{ACP}$, aliada a um menor tempo de moagem, resultou em maiores densidades relativas para os agentes metanol e ciclohexano. Contudo, para tempos de moagem iguais e inferiores a 30 minutos para o ácido esteárico, e 60 minutos para o etanol, as maiores densidades foram obtidas com uma menor quantidade desses ACPs. As análises de distribuição granulométrica e das microestruturas dos pós moídos indicaram que os agentes ácido esteárico e etanol são mais efetivos para inibir a soldagem dos pós em comparação com o metanol e ciclohexano. A partir das microestruturas, foi possível também constatar que a supressão do evento de soldagem e, consequentemente, da formação de agregados de alumínio contendo lamelas finas de nióbio, favoreceu a obtenção de maiores densidades relativas. Essa supressão também foi evidenciada pela fração volumétrica de partículas isoladas (não associadas com o alumínio) de nióbio (TAB. 24). As temperaturas de ignição registradas durante o processo, e também os tempos para as reações de combustão (verificados mediante o deslocamento dos perfis de temperatura para a direita) refletiram esse atraso no processo de ativação mecânica com a adição de uma maior quantidade de agente. Os aumentos mais significativos nas temperaturas de ignição foram observados para o ácido esteárico e etanol, sobretudo para tempos de moagem inferiores a 60 minutos. Estes resultados sugerem que certa quantidade de partículas isoladas de nióbio (por volta de 9\%, segundo os dados da TAB. 24), aliada a uma microestrutura com agregados de alumínio contendo lamelas pouco refinadas de nióbio, são benéficas para o processo de sinterização. A presença dessas partículas isoladas deve favorecer uma maior interconectividade da fase líquida (alumínio) com o nióbio, fato que contribui para uma melhor densificação em sistemas obtidos por sinterização com fase líquida. Além disso, a presença de partículas isoladas de nióbio promove um atraso nas reações de combustão. Tais atrasos, aliados a maiores temperaturas de ignição, favorecem a obtenção de temperaturas mais elevadas no momento da reação, auxiliando na sinterização das pastilhas.

As análises por difração de raios $X$ das misturas moídas e das pastilhas reagidas, aliadas às espectroscopias no infravermelho, indicam que houve uma decomposição parcial dos ACPs durante a moagem com alta energia. A presença 
de produtos de reação dos agentes com os pós metálicos, como $\mathrm{NbC} \mathrm{e} \mathrm{Al}_{2} \mathrm{O}_{3}$ (nas pastilhas reagidas) puderam ser observados com apenas 30 minutos de moagem. A fase $\mathrm{NbH}$ (nas misturas moídas) pôde ser identificada com apenas 18 minutos de moagem. A identificação das bandas de absorção no infravermelho dos grupos $\mathrm{C}=\mathrm{O}$ (característica do ácido esteárico) para 30 minutos de moagem com 1,5\% do ácido, e O-H (característica dos álcoois) para 18 minutos de moagem com 1,0\% de etanol e metanol, indica que a decomposição destes agentes foi apenas parcial.

A forma de atuação dos agentes ácido esteárico, etanol e metanol ocorreu possivelmente mediante a interação do oxigênio (após a quebra da ligação $\mathrm{O}-\mathrm{H}$ desses ACPs, com liberação de hidrogênio) com a superfície do alumínio. Essa adsorção dos agentes com os pós metálicos por meio do oxigênio pode ser responsável pela capacidade de lubrificação desses ACPs, o que explica a baixa eficiência do agente ciclohexano como inibidor da soldagem, uma vez que este é composto essencialmente por carbono e hidrogênio. 


\section{CONCLUSÕES}

Os resultados apresentados nesta investigação comprovam que o tipo e a quantidade de ACP apresentam efeitos altamente significativos na forma e microestrutura dos agregados formados durante o processo de ativação mecânica (moagem das misturas de pós de Nb75Al). Conseqüentemente, a densidade relativa das pastilhas reagidas de $\mathrm{NbAl}_{3}$ e o mecanismo da reação (avaliado por meio da temperatura de ignição) são diretamente afetados. Com base neste trabalho, as seguintes considerações podem ser formuladas:

1. Os efeitos das variáveis relativas ao ACP (tipo e quantidade) dependem do tempo de moagem adotado. Em geral, a adição de uma maior quantidade de agente produziu agregados de tamanhos menores e com uma estrutura menos lamelar. Observou-se também a presença de um maior número de partículas isoladas de nióbio, notadamente nas amostras moídas por 30 minutos com 0,5\% de ácido esteárico e etanol, e com $1,5 \%$ de metanol. A redução no tamanho dos agregados, juntamente com a presença de certa quantidade de partículas de nióbio não associadas com o alumínio, mostraram-se benéficas para a densificação das pastilhas reagidas. Dentre os agentes empregados, o etanol provocou mudanças mais expressivas nas misturas preparadas pelo mesmo tempo de moagem, porém com quantidades diferentes desse agente. Considerando os pós moídos por 30 minutos, os agentes ácido esteárico e etanol mostraram-se eficientes para a inibição da soldagem com adições de apenas $0,5 \%$. O agente ciclohexano foi ineficiente para prevenir a soldagem nas quantidades investigadas neste trabalho.

2. A adição de uma maior quantidade de ACP ocasionou um ligeiro atraso na ignição das reações. Tal efeito mostrou-se mais significativo nas pastilhas processadas a partir das misturas moídas com ácido esteárico e etanol.

3. As análises por difração de raios $X$ e espectroscopia no infravermelho indicam que ocorreu uma decomposição dos ACPs durante a moagem com alta energia. Essa decomposição pôde ser observada com apenas 18 minutos de moagem, pela identificação dos picos relativos à fase $\mathrm{NbH}$ nas misturas moídas. Os difratogramas das pastilhas reagidas mostraram a existência de partículas de 
$\mathrm{NbC}$ e $\mathrm{Al}_{2} \mathrm{O}_{3}$ com apenas 30 minutos de moagem. $\mathrm{A}$ identificação das bandas de absorção no infravermelho dos grupos $\mathrm{C}=\mathrm{O}$ (característica do ácido esteárico) para 30 minutos de moagem com 1,5\% do ácido, e O-H (característica dos álcoois) para 18 minutos de moagem com 1,0\% de etanol e metanol, indica que a decomposição desses agentes foi apenas parcial. O mecanismo de atuação dos ACPs ácido esteárico, etanol e metanol com os pós de Nb75Al durante o processo de moagem ocorre possivelmente por meio da interação do oxigênio do grupo $\mathrm{OH}$, após quebra desta ligação com liberação de hidrogênio, com a superfície dos pós metálicos, notadamente com o alumínio (elemento com maior afinidade pelo oxigênio).

4. Para cada tipo de ACP empregado na etapa de preparação das misturas mecanicamente ativadas, há uma quantidade ideal para um determinado tempo de moagem, no que concerne a uma melhor densificação do produto final. Estas variáveis foram investigadas por meio da elaboração de planejamentos de experimentos do tipo composto central para cada tipo de agente. Foi possível construir modelos empíricos, notadamente para o metanol e ciclohexano, capazes de relacionar numericamente as variáveis investigadas e indicar a melhor condição para se obter a maximização da resposta avaliada, aqui definida pela densidade relativa das pastilhas de $\mathrm{NbAl}_{3}$. 


\section{SUGESTÕES PARA TRABALHOS FUTUROS}

Em continuidade ao estudo desenvolvido até o momento, os seguintes experimentos adicionais são propostos:

1. Investigação mais profunda e detalhada da interação dos agentes com as partículas dos pós metálicos, especialmente com o auxílio da microscopia eletrônica de transmissão.

2. Determinação da fração volumétrica das fases $\mathrm{NbC} \mathrm{e} \mathrm{Al}_{2} \mathrm{O}_{3}$ identificadas nas pastilhas reagidas, por meio da análise dos difratogramas pelo método de Rietveld.

3. Elaboração de um planejamento do tipo composto central para o etanol, na região onde foram obtidas as maiores densidades relativas, visando melhorar a qualidade do ajuste do modelo e obter uma melhor indicação da condição ideal para maximizar a resposta.

4. Análise química das misturas moídas, sobretudo com relação aos teores de oxigênio e carbono, antes e após moagem com alta energia com os diferentes ACPs. 


\section{ANEXO - Conceitos principais para a interpretação dos resultados obtidos nos planejamentos de experimentos}

\section{Avaliação da qualidade do ajuste de um modelo}

A elaboração de modelos empíricos (em geral, lineares ou quadráticos) possibilita descrever, realizar predições e otimizar processos, por meio da construção de superfícies de resposta. Para tal finalidade, a qualidade do ajuste de um modelo deve ser verificada. Essa avaliação é comumente realizada por meio da análise dos gráficos dos resíduos e pela análise de variância (ANOVA). O método consiste em decompor algebricamente os desvios observados para uma resposta individual em relação à média de todas as respostas observadas (denominada de média global ou grande média), em duas parcelas: a primeira representa o desvio do valor previsto pelo modelo em relação à média global (parcela descrita pela equação de regressão), ao passo que a segunda representa a diferença entre o valor observado no ensaio e o valor previsto pelo modelo adotado (resíduos). Em modelos bem ajustados, o valor da segunda parcela deve ser o menor possível (Barros Neto et al., 2002). Em termos numéricos, essa decomposição pode ser representada pela seguinte equação.

$$
\Sigma\left(y_{i}-\breve{y}\right)^{2}=\Sigma\left(\hat{y}_{i}-\breve{y}\right)^{2}+\Sigma\left(y_{i}-\hat{y}_{i}\right)^{2}
$$

onde $\left(y_{i}-\breve{y}\right)$ representa os desvios das respostas observadas $\left(y_{i}\right)$ em relação à média global $(\breve{y}),\left(\hat{y}_{i}-\breve{y}\right)$ representa o desvio da previsão realizada pelo modelo $\left(\hat{y}_{i}\right)$ em relação à média global e $\left(y_{i}-\hat{y}_{i}\right)$ indica a diferença entre o valor da resposta observada e o valor da resposta prevista pelo modelo. Estas somas dos quadrados dos desvios são comumente denominadas de somas quadráticas (SQ). Utilizando uma notação mais compacta, a equação acima pode ser reescrita como:

$$
S Q_{T}=S Q_{R}+S Q_{r}
$$

onde $S Q_{T}$ é a soma quadrática em torno da média, $S Q_{R}$ representa a soma quadrática em torno da regressão e $S Q_{r}$ indica a soma quadrática residual. É evidente que quanto maior for a fração descrita pela regressão, melhor será o ajuste do modelo. 
A cada soma quadrática há certo número de graus de liberdade associados, que indicam a quantidade de valores independentes utilizados para determiná-la. O produto da divisão da soma quadrática pelo seu respectivo número de graus de liberdade é chamado de média quadrática (MQ). A esta última é atribuída uma interpretação estatística, responsável por avaliar o grau de significância da equação de regressão prevista pelo modelo, bem como a qualidade do ajuste deste, por meio da aplicação de testes dentro de certos intervalos de confiança. Assumindo que os erros sigam uma distribuição normal, pode-se demonstrar que a razão entre médias quadráticas segue uma distribuição de Fisher (comumente denominada de teste F).

$$
\frac{M Q_{R}}{M Q_{r}}
$$

onde $M Q_{R}$ é a média quadrática em razão da regressão, $M Q_{r}$ é a média quadrática residual e $F_{G L R, G L r}$ é a distribuição de Fisher com os respectivos números de graus de liberdade em razão da regressão $(G L R)$ e dos resíduos $(G L r)$.

A significância estatística da regressão é determinada por meio da comparação direta entre o valor de $F_{G L R, G L r}$ calculado pela equação $\left(F_{\text {calc. }}\right)$ e 0 valor de $F_{G L R, G L r}$ tabelado $\left(F_{\text {tab. }}\right)$, no nível de confiança desejado. A equação de regressão é considerada significativa quando o valor calculado de $M Q_{R} / M Q_{r}$ for superior ao valor de $\mathrm{F}_{\text {tab. }}$. Na prática, contudo, é recomendável considerar um modelo válido para realizar previsões quando o valor de $M Q_{R} / M Q_{r}$ for cerca de 10 vezes maior do que o valor de $F_{\text {tab. }}$, para um dado intervalo de confiança.

A avaliação da qualidade do ajuste de um modelo também pode ser verificada por meio da aplicação de teste F. Nesse caso, a $M Q_{r}$ é decomposta em duas parcelas. A primeira representa uma medida do erro aleatório, denominado de erro puro. Esse erro representa a dispersão nos valores das respostas com a repetição dos ensaios. A segunda parcela, ao contrário, depende do modelo adotado e fornece uma medida da falta de ajuste deste em relação às respostas observadas.

$$
M Q_{r}=M Q_{e p}+M Q_{f a j}
$$


onde $M Q_{r}$ representa a média quadrática residual, $M Q_{e p}$ indica a média quadrática em razão do erro puro e $M Q_{f a j}$ é a média quadrática em razão da falta de ajuste do modelo.

Da mesma forma como descrito na avaliação da significância estatística da regressão, a validade do modelo adotado também pode ser verificada mediante a comparação direta entre o valor de $F_{\text {GLfaj,GLep }}$ calculado pela equação ( $\left.F_{\text {calc. }}\right)$ e o valor de $F_{\text {GLfaj,GLep }}$ tabelado $\left(F_{\text {tab.,com: }}\right.$ GLfaj - graus de liberdade associados à falta de ajuste; GLep - graus de liberdade em razão do erro puro). O modelo está bem ajustado às observações se $F_{c a l c}$. $<F_{\text {tab. }}$, possibilitando a construção de superfícies de resposta na região investigada e a estimativa dos efeitos principais e interações entre as variáveis.

\section{Determinação dos efeitos principais e interações de dois fatores}

Por definição, o efeito principal de uma determinada variável é obtido pela média dos efeitos desta nos dois níveis das demais variáveis. Este valor indica que a resposta de interesse, em média, aumenta ou diminui quando o nível da outra variável passa de seu limite inferior (-) para o superior (+). A expressão seguinte ilustra o cálculo do efeito principal num planejamento de dois níveis, que também pode ser entendido como a diferença entre as respostas médias no nível superior e inferior de uma dada variável.

$$
V_{1,2}=\check{y}_{+}-\breve{y}_{-}
$$

onde $V_{1,2}$ representa o efeito principal para um dado fator (ou variável), $\breve{y}_{+}$é a

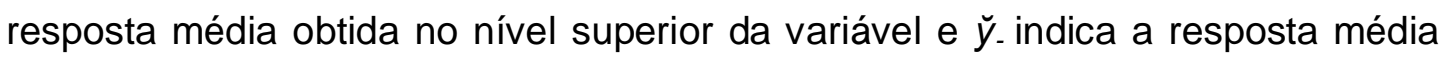
obtida no nível inferior.

A medida da interação entre as variáveis pode ser obtida pela metade da diferença entre as médias dos efeitos de uma variável nos níveis inferior e superior da outra variável.

$$
V_{1} V_{2}=\frac{\check{y}_{+(2)}-\check{y}_{-(2)}}{2}
$$


onde $V_{1} V_{2}$ representa o efeito de interação entre as variáveis $x_{1}$ e $x_{2}, \breve{y}_{+(2)}$ indica a resposta média do efeito da variável $x_{1}$ no nível superior da variável $x_{2}$ e $\breve{y}_{-(2)}$ é a resposta média do efeito da variável $x_{1}$ no nível inferior de $x_{2}$, ou vice-versa.

Na prática, é mais comum apresentar a estimativa dos efeitos principais e interações entre as variáveis por meio dos valores calculados para os coeficientes ou parâmetros do modelo, que correspondem à metade dos valores encontrados no cálculo de seus efeitos e interações.

Para determinar a significância estatística dos efeitos e interações calculados, deve-se ter uma maneira de estimar o erro experimental do processo. Nos planejamentos compostos centrais, essa medida pode ser realizada mediante repetições no ponto central. Neste estudo, o erro experimental (desvio padrão de uma dada observação) de cada planejamento foi determinado, com quatro graus de liberdade (número de repetições no ponto central menos 1), a partir das cinco repetições realizadas na condição padrão. De forma similar, o erro padrão dos coeficientes do modelo pode ser determinado segundo a equação:

$$
s_{b}=\sqrt{ } s^{2} / n
$$

onde $s_{b}$ representa o erro padrão do coeficiente do modelo, $s^{2}$ é a estimativa da variância do processo e $n$ é o número de combinações lineares das variáveis para as respostas observadas.

Para um dado intervalo de confiança, os parâmetros do modelo considerados estatisticamente significativos são aqueles que superam em valor absoluto o produto do seu erro padrão $\left(s_{b}\right)$ pelo ponto da distribuição de Student $(t)$ com seus respectivos graus de liberdade. Esse critério permite calcular intervalos de confiança (I.C.) para os efeitos ou os coeficientes do modelo. Caso o intervalo calculado não contenha o zero, os coeficientes são considerados estatisticamente significativos no nível de confiança adotado.

$$
\text { I.C. }=b \pm t \times s_{b}
$$

onde I.C. é o intervalo de confiança no nível desejado, $b$ representa os coeficientes do modelo, $t$ é a distribuição de Student e $s_{b}$ é o erro padrão dos coeficientes do modelo. 


\section{REFERÊNCIAS BIBLIOGRÁFICAS}

ARIAS, A. Chemical reactions of metal powders with organic and inorganic liquids during ball milling, NASA TN D-8015, National Technique Information Service (NTIS), Springfield, VA, 1975.

BARROS NETO, B.; SCARMINIO, I.S.; BRUNS, R.E. Como fazer experimentos: Pesquisa e desenvolvimento na ciência e na indústria, Unicamp, 2 ed., 2002.

BARTH, E.P.; TIEN, J.K.; UEJO, S.; KAMBARA, S. High temperature strengh of niobium aluminide intermetallics, Materials Science and Enginnering, v. A 153, p. 348-401, 1992.

BENJAMIN, J. S. Mechanical alloying, Scientific American, v. 234, n.5, p. 40-48, 1976.

BENJAMIN, J. S.; VOLIN, T. E. Mechanisms of mechanical alloying, Metallurgical Transactions, v. 5, n. 8, p. 1929-1934, 1974.

BOLDYREV, V. V. Mechanical activation and its application in technology, Materials Science Forum, v. 269-272, p. 227-234, 1998.

BOX, G.E.P.; HUNTER, W.G.; HUNTER, J.S. Statistics for experimenters, John Wiley \& Sons, 1978.

CHAN, T.Y.; LIN, S.T. Effects of stearic acid on the injection molding of alumina, Journal of the American Ceramic Society, v. 78, n. 10, p. 2746-2752, 1995.

FRAZIER, W.E.; KOCKZAK, M.J. Mechanical and thermal stability of powder metallurgy aluminum-titanium alloys, Scripta Metallurgica, v. 21, p. 129-134, 1987.

GAUTHIER, V.; JOSSE, C.; BERNARD, F.; GAFFET, E.; LARPIN, J.P. Synthesis of niobium aluminides using mechanically activated self-propagating hightemperature synthesis and mechanically activated annealing process, Materials Science and Enginnering, v. A265, p. 117-128, 1999.

HIBINO, A.; MATSUOKA, S.; KIUCHI, M. Synthesis and sintering of $\mathrm{Ni}_{3} \mathrm{Al}$ intermetallic compound by combustion synthesis process, Journal of Materials Processing Technology, v. 112, p. 127-135, 2001.

JANGG, G.; KUTNER, F.; KORB, G. Dispersion hardening of aluminium with $\mathrm{Al}_{4} \mathrm{C}_{3}$, Powder Metallurgy International, v. 9, n. 1, p. 24-26, 1977. 
KACHELMYER, C.R.; ROGACHEV, A.S.; VARMA, A. Mechanistic and processing studies in combustion synthesis of niobium aluminides, Journal of Materials Research, v. 10, n. 9, p. 2260-2270, 1995.

KATTNER, U. R. Binary alloy phase diagrams, Materials Park: ASM, 2 ed., p. 179-180, 1996.

KLEINER, S.; BERTOCCO, F.; KHALID, F.A.; BEFFORT, O. Decomposition of process control agent during mechanical milling and its influence on displacement reactions in the $\mathrm{Al}-\mathrm{TiO}_{2}$ system, Materials Chemistry and Physics, v. 89, p. 362-366, 2005.

LAI, M.O.; LÜ, L. Mechanical alloying. Boston, MA: Kluwer Academic Publishers, 1998.

LEAL NETO, R. M.; ROCHA, C. J. Effect of the high-energy ball milling on the combustion synthesis of $\mathrm{NbAl}_{3}$, Key Enginnering Materials, v. 189-191, p. 567-572, 2001.

LEAL NETO, R. M.; ROCHA, C. J., AMBROZIO FILHO, F. Combustion synthesis of high energy ball milled $\mathrm{Nb}+3 \mathrm{Al}$ powder mixtures, Materials Science Forum, v. 416-418, p. 156-161, 2003.

LEE, W.; KWUN, S.I. The effects of process control agents on mechanical alloying mechanisms in the Ti-Al system, Journal of Alloys and Compounds, v. 240, p. 193-199, 1996.

LIN, C.N.; CHUNG, S.L. Combustion synthesis of aluminum nitride powder using additives, Journal of Materials Research, v. 16, n. 8, p. 2200-2208, 2001.

LIU, Z.G.; GUO, J.T. Formation mechanism of TiC by mechanical alloying, Applied Physical Letters, v. 65, p. 2666-2668, 1994.

LU, L.; ZHANG, Y.F. Influence of process control agent on interdiffusion between $\mathrm{Al}$ and $\mathrm{Mg}$ during mechanical alloying, Journal of Alloys and Compounds, v. 290 , p. $279-283,1999$.

MAURICE, D. R.; COURTNEY, T. H. The Physics of mechanical alloying: a first report, Metallurgical Transactions A, v. 21, n. 2, p. 289-303, 1990.

MERCK INDEX, An Encyclopedia of Chemicals, Drugs and Biologicals, USA, Merck \& Co, Inc, 10 ed., 1983. 
MIURA, S.; OHASHI, T.; MISHIMA, Y. Amount of liquid phase during reaction synthesis of nickel aluminides, Intermetallics, v. 5, p. 45-49, 1997.

MOORE, J.J.; FENG, H.J. Combustion synthesis of advanced materials: Part I. Reaction parameters, Progress in Materials Science, v. 39, p. 243-273, 1995.

MORRIS, D.G.; MORRIS, M.A. Mechanical alloying of Fe-Al with oxide and carbide dispersoids, Materials Science and Enginnering, v. A125, p. 97-106, 1990.

MUNIR, Z. A.; ANSELMI-TAMBURINI, U. Self-propagating exothermic reactions: the synthesis of high temperature materials by combustion, Materials Science Reports, v. 3, p. 277-365, 1989.

PARK, H.S.; SHIN, K.S. Effect of mechanical alloying on combustion synthesis of $\mathrm{MoSi}_{2}$, Journal of Materials Research, v. 16, n. 11, p. 3060-3068, 2001.

PATIL, K.C.; ARUNA, S.T.; MIMANI, T. Combustion Synthesis: an update, Solid State and Materials Science, v. 6, p. 507-512, 2002.

PINTO, L. C. M. Quantikov - Um analisador microestrutural para o ambiente Windows, 1996. Tese (Doutorado) - Instituto de Pesquisas Energéticas e Nucleares, São Paulo.

PORTNOY, V. K.; TRETJAKOV, K. V.; STRELETSKII, A. N.; BERESTETSKAYA, I. V. Mechanochemical synthesis of niobium hydrides, Materials Science Forum, v. 343-346, p. 453-460, 2000.

ROCHA, C.J.; ARAÚJO, E.G.; NOGUEIRA, R.A.; AMBROZIO FILHO, F. Effect of wax addition on monel synthesis by high energy milling, Materials Science Forum, v. 299-300, p. 457-462, 1999.

ROCHA, C. J.; LEAL NETO, R. M.; GONÇALVES, V. S.; CARVALHO, L. L.; AMBROZIO FILHO, F. An investigation of the use of stearic acid as a process control agent in high-energy ball milling of $\mathrm{Nb}-\mathrm{Al}$ and $\mathrm{Ni}-\mathrm{Al}$ powder mixtures, Materials Science Forum, v. 416, p. 144-149, 2003.

ROCHA, C. J.; GONÇALVES, V. S.; LEAL NETO, R. M. Mechanical activation of $\mathrm{Nb75Al}$ mixtures using shaker and planetary ball mills, Materials Science Forum, v. 530-531, p. 203-210, 2006.

SAUTHOFF, G. Intermetallics. Weinheim, New York, Basel, Cambridge, Tokyo: $\mathrm{VCH}, 1995$. 
SHACKELFORD, J.F.; ALEXANDER, W. CRC Materials Science and Enginnering Handbook, 3 ed., CRC Press, 2001.

SCHNEIBEL, J.H.; GRAHLE, P.; RÖSLER, J. Mechanical alloying of FeAl with $\mathrm{Y}_{2} \mathrm{O}_{3}$, Materials Science and Enginnering, v. A153, p. 684-690, 1992.

SHAW, L.; ZAWRAH, M.; VILLEGAS, J.; LUO, H.; MIRACLE, D. Effects of process-control agents on mechanical alloying of nanostructured aluminum alloys, Metallurgical and Materials Transactions A, v. 34, p. 159-170, 2003.

SINGER, R.F.; OLIVER, W.C.; NIX, W.D. Identification of dispersoid phases created in aluminum during mechanical alloying, Metallurgical Transactions A, v. 11, p. 1895-1901, 1980.

SKOOG, D. A.; HOLLER, F. J.; NIEMAN, T. A. Princípios de análise instrumental, 5 ed., Bookman, p. 342-382, 2006.

SUBRAHMANYAM, J.; VIJAYAKUMAR, M. Review Self-propagating high temperature synthesis, Journal of Materials Science, v. 27, p. 6249-6273, 1992.

SURYANARAYANA, C. Mechanical alloying and milling, Progress in Materials Science, v. 46, p. 1-184, 2001.

TAKACS, L. Self-sustaining reactions induced by ball milling, Progress in Materials Science, v. 47, p. 355-414, 2002.

TIMSIT, R.S.; BOCK, E.M.; CORMAN, N.E. Effect of surface reactivity of lubricants on the properties of aluminum electrical contacts, IEEE Transactions on Components, Packaging and Manufacturing Technology, v. A21, n. 3, p. 500-505, 1998.

WILLIAMS, J.C. Intermetallics for structural applications; potential, reality and the road ahead, Structural intermetallics, p. 3-8, 1997.

UNDERHILL, R.; TIMSIT, R.S. Interaction of aliphatic acids and alcohols with aluminum surfaces, Journal of Vacuum Science Technology A, v. 10, n. 4, p. 2767-2774, 1992.

VARMA, A.; MUKASYAN, A.S. Combustion synthesis of advanced materials, ASM Handbook, v. 7, 1998.

ZHANG, Y.F.; LU, L.; YAP, S.M. Prediction of the amount of PCA for mechanical milling, Journal of Materials Processing Technology, v. 89-90, p. 260-265, 1999. 